UNIVERSIDADE DE SÃO PAULO

FACULDADE DE FILOSOFIA, LETRAS E CIÊNCIAS HUMANAS

DEPARTAMENTO DE HISTÓRIA

PROGRAMA DE PÓS-GRADUAÇÃO EM HISTÓRIA SOCIAL

\title{
EXPERIÊNCIA E MEMÓRIA \\ A PALAVRA CONTADA E A PALAVRA CANTADA \\ DE UM NORDESTINO NA AMAZÔNIA
}

Fabíola Holanda Barbosa

São Paulo, 2006 


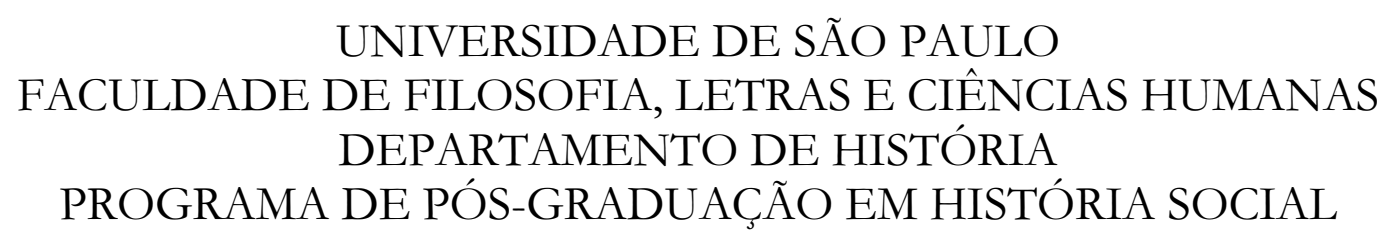

\section{EXPERIÊNCIA E MEMÓRIA}

\section{A PALAVRA CONTADA E A PALAVRA CANTADA DE UM NORDESTINO NA AMAZÔNIA}

Fabíola Holanda Barbosa

Tese apresentada ao Programa de PósGraduação em História Social, do Departamento de História da Faculdade de Filosofia, Letras e Ciências Humanas da Universidade de São Paulo, para obtenção do título de doutor em História.

Orientador: Prof. Dr. José Carlos Sebe Bom Meihy 
EXPERIÊNCIA E MEMÓRIA

A Palavra Contada e a Palavra Cantada

de um Nordestino na Amazônia 
Para Adálio Pereira de Oliveira, colaborador ideal. Para meus avôs, Antônio e Josué. (in memória) Para minhas avós, Izabel e Ester. 


\section{AGRADECIMENTOS}

Aos meus pais: Jailson e Zezinha, por confiarem sempre e pelo convívio na "nossa" Perdizes.

A Bianca, Alexandre (que já é irmão) e Vinícius, pelo apoio e "salvamentos".

A Diogo (também, pelas inúmeras traduçôes urgentes e inadiáveis) e Carol (também, irmã), companheiros de república.

A Marcelo, pelo companheirismo e pela infra-estrutura emocional e física nos últimos tempos.

A Luana e Filipe, pela amizade, pela capa, pelos jantares e vinhos e pela "Liberdade".

Á Suzana e Ioka, pelo apoio na chegada, pelos projetos conjuntos e planos futuros.

Aos meus alunos e amigos do Centro de Hermenêutica do Presente: Ednéia, Ariana, Cristiane, Deyvesson, Joesér, Márcia, Vanessa e Xênia, por acreditarem no sonho.

Aos companheiros do NEHO/USP: Ana Luíza, Ana Maria, Andréa Paula, Alfredo, Fábio, Gustavo, Maurício, Maria, Natanael, Samira e Valéria, pelo diálogo, pela acolhida e pelo debate em história oral.

A Prof Jerusa Pires Ferreira, por ter me acolhido no grupo de Estudos da Oralidade e pelas idéias.

Ao Prof. Januário Amaral pelo apoio institucional e incondicional.

A Universidade Federal de Rondônia, À Fundação Rio Madeira e a CAPES pelo apoio financeiro.

E, especialmente, ao Prof. José Carlos Sebe Bom Meihy, mais que um orientador, um exemplo amigo e intelectual. 


\title{
RESUMO
}

Esta pesquisa buscou pensar as relações de experiência, memória e oralidade como dimensões de uma linha específica de história oral que cada vez mais se pretende autônoma e pública.

Essas relações foram feitas a partir de duas formas narrativas: uma contada - construída em colaboração durante entrevistas com procedimentos dessa história oral e outra narrativa cantada composição musical que Adálio Pereira de Oliveira, um nordestino na Amazônia, fez para contar sua história de vida.

Essa linha de história oral valoriza os aspectos subjetivos das experiências narradas e possui pressupostos epistemológicos claros: a colaboração, a mediação e a dimensão pública do texto produzido.

Palavras-Chave: História Oral, Narrativa, Colaboração.

\begin{abstract}
This research intended to think about experiences and their relations, memories and orality as dimensions of a specific oral history that becomes more autonomous and public.

Those relations were maid from two narrative forms: one: spoken - built on interviews with a certain oral history procedures and the other: narrative song-composed that Adálio Pereira de Oliveira, a northeastern in Amazon, made to tell his history of life.
\end{abstract}

This oral history line values the subjective aspects of narrated experiences and clear epistemological beddings: common work, mediation and the public dimension of the document.

Key Words: Oral History, Narrative, common work. 


\section{ÍNDICE}

\section{PARTE I EXPERIÊNCIA E MEMÓRIA}

OS CAMINHOS DA NARRATIVA OU HISTÓRIA DO PROJETO 26

UM POUCO DE VIDA

A ESCOLHA DO TEMA E A HistÓRIA DO PROJETO 28

A COMUNIDADE SANTA MARCELINA E O ENCONTRO COM ADÁLIO 37

OS CAMINHOS DA NARRATIVA E AS ENTREVISTAS

\section{PARTE II A HISTÓRIA DE UM NORDESTINO NA AMAZÔNIA}

ADÁLIO PEREIRA DE OLIVEIRA $\quad 47$

A PALAVRA CONTADA

$\begin{array}{ll}\text { A JORNADA } & 48\end{array}$

$\begin{array}{ll}\text { A ESCOLA } & 65\end{array}$

OS SONHOS $\quad 82$

A MÚSICA $\quad 93$

A PALAVRA CANTADA

PARTE III A PALAVRA CONTADA E A PALAVRA CANTADA: UMA LEITURA

PALAVRA CONTADA E A PALAVRA CANTADA: UMA LEITURA POSSÍVEL 116

ABERTURA $\quad 116$

A PALAVRA CONTADA 118

$\begin{array}{ll}\text { A Jornada } & 118\end{array}$

$\begin{array}{lr}\text { A Escola } & 148\end{array}$

Os Sonhos $\quad 152$

A Música $\quad 153$

PALVARA CANTADA 156

A PALAVRA CONTADA E A PALAVRA CANTADA:_UMA CONCLUSÃO POSSÍVEL 162

BIBLIOGRAFIA

HISTÓRIA ORAL/ ORALIDADE/ MEMÓRIA 167

AMAZÔNIA/RONDÔNIA 169

$\begin{array}{ll}\text { GERAL } & 170\end{array}$

$\begin{array}{ll}\text { GALERIA } & 173\end{array}$ 


\section{APRESENTAÇÃO}

Quero iniciar a apresentação da minha tese pelo título que escolhi: "Experiência e Memória: A Palavra Contada e a Palavra Cantada de um Nordestino na Amazônia”.

Experiência e Memória por serem dimensões que delimitam o campo da história oral que milito. Experiência como resultado de uma vivência específica, singular, do aprendizado da vida. Memória como exercício, construção, uma elaboração sobre a experiência vivenciada, narrada no momento da entrevista.

A "Palavra Contada" e a "Palavra Cantada" por serem dimensões dadas por Adálio na própria maneira de narrar sua experiência. Durante sua entrevista, construída em colaboração a partir de procedimentos de uma dada história oral, ele cantou uma música que compôs durante os anos em que esteve nos seringais da Amazônia. A música, "A História de um Nordestino na Amazônia", é sobre sua vida e nos deu um eixo próprio, advindo da sua compreensão sobre o que significou sua vida. A palavra cantada se apresentou como fio condutor da palavra contada, mas que em alguns momentos silenciava sobre determinados temas que foram contados na entrevista. Esses vazios, silêncios, omissões, geraram em mim inquietações e muitas perguntas sobre narratividade, oralidade, memória, tudo isso como aspectos de uma narrativa que conta uma experiência única, preocupação central da história oral em que me insiro. Estou pensando narrativa como maneira de contar essas experiências vividas, valorizando-a, como nos diz Meihy, enquanto "elemento comunicativo prenhe de sugestões" (1991: 31) e, ao mesmo tempo, como idéia de captação de cultura desenvolvida por Ferreira ${ }^{1}$ (2004), nos seus trabalhos sobre oralidade e memória. O fazer desse novo texto (a narrativa) permite, como afirma Meihy, "que se pense a entrevista como algo ficcional e, sem constrangimento, se aceita esta condição no lugar de uma cientificidade que seria ainda mais postiça" (1991: 31).

De "um nordestino na Amazônia" porque é dessa maneira que Adálio se apresenta e por ser um dos elos de aproximação entre eu e meu colaborador. Demorei a entender os motivos de tanta identificação, da necessidade de compreender esse homem e de lutar por sua narrativa em particular. Somente numa conversa com meu orientador, quando ele apontou para o subtítulo inicial do meu trabalho: "História Oral de um Nordestino na Amazônia" e me perguntou: "Quem é esse nordestino na Amazônia?" E eu respondi: "É o meu colaborador, ele é nordestino, foi para a Amazônia como "Soldado da Borracha”, durante a Segunda Guerra Mundial.” E ele pacientemente me olhou e insistiu: “Quem é esse nordestino na Amazônia?” E eu continuei sem entender. Até que

\footnotetext{
${ }^{1}$ Essa idéia foi apresentada pela Professora Jerusa Pires Ferreira durante a disciplina: "Poéticas do Oral, Ritmos, Velocidades, Movimentos" ministrada no Programa de Pós-Graduação em Semiótica-PUC/SP no segundo semestre de 2004.
} 
ele percebendo que eu não chegaria sozinha perguntou: “O que você é? Onde você está agora?” E eu entendi: era sobre mim que estávamos falando: sou uma nordestina na Amazônia.

Para ser coerente com a história oral que estou seguindo, que se pauta nos princípios de colaboração e que põe a entrevista no centro da pesquisa, precisava de uma estrutura que evidenciasse a narrativa, colocando meu colaborador no centro do trabalho.

Por isso iniciei com a Parte I "História do Projeto ou Os Caminhos da Narrativa", pretendendo fazer uma "descrição" de minha trajetória enquanto oralista, dos passos do projeto, dos caminhos escolhidos, das reflexões teóricas em torno da história oral e das questões que ela incita, de como realizei as entrevistas com Adálio e como estou apresentando-as nesse trabalho. É tentativa de preparar o leitor para a parte principal do trabalho, mas preparar não no sentido de dirigir o olhar e a compreensão, mas de explicar como cheguei até aquele corpus narrativo que apresentarei no capítulo seguinte e que é parte fundamental do trabalho.

A Parte II é o texto de Adálio Pereira de Oliveira, meu colaborador. Nessa parte é ele que se expõe, ele mesmo quem fala, ele quem conta e articula sua experiência. É o momento dele. Sua narrativa está dividida em duas partes: a "Palavra Contada" e a "Palavra Cantada". As explicações sobre essa divisão se encontra já delineada no primeiro capítulo.

$\mathrm{Na}$ terceiro Parte, desenvolvo uma leitura geral do texto-Adálio. E depois pretendo discutir as escolhas temáticas entre a narrativa da canção e do texto geral da entrevista.

Defini Adálio como “texto" para indicar que a compreensão "cristalizada” do homem, do poeta e da sua narrativa é constructo verbal, estruturado e culturalmente localizado, simbolicamente produzido por diversas instâncias sociais. A narrativa de Adálio é texto no sentido de que os elementos sociais (seca, miséria, sertão, soldado da borracha, Amazônia, doença, etc), que o circunscrevem, podem determinar as escolhas temáticas apresentadas em suas entrevistas e na sua música. Essa é perspectiva de análise encontrada na história oral, na medida que valoriza a narrativa, que é texto construído em colaboração. A minha expectativa é que isso gerasse uma outra interpretação própria dessa história oral, mas aqui na tese só consegui indicar um possível caminho.

O caminho pode ser de uma história pública, essa história oral, que valoriza a construção da narrativa e que possui pressupostos epistemológicos claros: a colaboração, a mediação e a dimensão pública do texto produzido, buscando saltar os muros da academia e buscando um maior impacto e inserção social do texto em história oral em espaços maiores.

Por fim, gostaria de apresentar como anexo um CD com a composição do meu colaborador e algumas fotos ilustrativas para que o leitor possa visualizar melhor o local das entrevistas e conhecer o meu colaborador. 


\section{PARTE I}

\section{EXPERIÊNCIA E MEMÓRIA}




\section{OS CAMINHOS DA NARRATIVA OU HISTÓRIA DO PROJETO}

Contar a história de um projeto é quase um trabalho de ego-história² ${ }^{2}$ Explicitar esse trajeto é fundamental em trabalhos acadêmicos, especialmente em história oral, onde as escolhas operacionais, caminhos trilhados, estão muito ligadas às questões pessoais, de experiências compartilhadas com sua comunidade de destino ${ }^{3}$. Daí iniciar o texto contando um pouco do caminho pessoal e como cheguei ao tema de pesquisa. Depois, os rumos e procedimentos que tomei, até o encontro com o tema deste trabalho. Explicando de onde falo e justificando o meu campo de atuação em história oral, esperando não ter caído na ilusão biográfica ou autobiográfica que nos alerta Bourdieu (1996, 183-191), de que essas narrativas tratam, normalmente, uma vida como uma trajetória de coerência, como um fio único, quando sabemos que, na existência de qualquer pessoa, multiplicam-se as causalidades, as oportunidades, as escolhas, as sortes.

\section{Um pouco de vida}

Cheguei a Porto Velho, Rondônia, indo do Recife, em julho de 1993, e, ainda, finalizando minha graduação em história. Tinha quase 20 anos e muitos e novos caminhos se apresentaram, e fui assumindo-os intuitivamente. A primeira decisão foi escolher entre finalizar o curso na Universidade Federal de Rondônia ou voltar para Recife e conclú-lo onde iniciei, na Universidade Federal de Pernambuco. As minhas pretensões acadêmicas eram jovens como eu mesma o era nesse período. Optei por ficar em Porto Velho e concluir o curso na UNIR. Essa escolha me aproximou dos temas da região, das problemáticas locais e pouco a pouco fui adentrando no cosmo amazônico. A aproximação com este "novo mundo" foi fundamental, pois vinha de uma experiência de pesquisa em História, iniciada no segundo semestre da graduação, onde tinha como foco o Nordeste e o trabalho de pesquisa em arquivo público, com uma documentação muito peculiar. Num primeiro momento trabalhei com jornais da segunda metade do século XIX buscando compreender a partir das notícias sobre conflitos entre portugueses e brasileiros o comércio a retalho na cidade do Recife. Essa pesquisa se vinculava a um projeto multidisciplinar sobre a História do Nordeste e envolvia os cursos de História, Direito e Economia da UFPE, sob a orientação do Prof. Dr. Marc Jay Hoffnagel,

\footnotetext{
${ }^{2}$ Pierre Nora lançou a idéia de "ego-história" numa coletânea de ensaios onde estão reunidas oito autobiografias: George Duby, Jacques Le Goff, Pierre Duby, dentre outros. Eram autores conhecidos falando sobre sua trajetória pessoal ou relacionando-a com a escolha de determinado período ou campo histórico.

${ }^{3} \mathrm{O}$ Conceito de comunidade de destino foi estabelecido por meihy para designar o grupo de pessoas que iremos estudar, é aquilo que identifica as pessoas, o motivo, os traços que as reúnem em características afins (1996: 53-67).
} 
do departamento de História daquela Universidade. Então, meu plano individual de trabalho consistiu em buscar e analisar as notícias sobre os conflitos entre Portugueses e Brasileiros no jornal "O Brado do Povo" que veiculava no período pesquisado e apresentava uma linha editorial que se posicionava a favor dos comerciantes brasileiros. Outra experiência importante com a pesquisa em História foi o estágio no Arquivo Público Estadual de Pernambuco na organização do acervo do Departamento de Ordem Política e Social-DOPS, que estava saindo da guarda da Secretaria de Segurança Pública e sendo recebido pela Secretaria de Educação e Cultura, para que fosse organizado e disponibilizado, posteriormente, ao público. Além disso, realizei pesquisas particulares em jornais e na seção de manuscritos. Essa vivência no Arquivo, que durou até minha ida para Porto Velho, me pôs em contato com a documentação que fundamentou minha monografia de final de curso sobre insurreições de escravos ocorridas nos municípios da Zona da Mata de Pernambuco, no período de 1842/1866. A base documental foram as correspondências trocadas entre delegados, chefes de polícia e senhores de escravos, que faziam parte do Códice Polícia Civil, da Seção de Manuscritos do Arquivo Público Estadual de Pernambuco.

Demorei a me desvincular dos temas do Nordeste e do século XIX, pois apesar de estar cursando o Bacharelado na Federal de Rondônia, minha monografia versava sobre História de Pernambuco e, ainda que tivesse cursado disciplinas como: História Regional; História da Amazônia, não conseguia identificar-me com temas regionais macro: ciclos econômicos da Amazônia, o garimpo, a borracha, a construção da BR 364; os projetos de colonização; os ribeirinhos, os índios. Só alguns anos mais tarde é que encontrei o "meu Norte".

Os três anos seguintes após o término do curso foram dedicados ao ensino de História: ministrei aulas em turmas do ensino fundamental, médio e pré-vestibulares e ainda tive uma experiência especial como coordenadora pedagógica do ensino médio. Dessa experiência nasceu em mim o gosto pelo ensino, pela sala de aula, pois antes, quando ainda cursava a graduação, meu objetivo era a pesquisa em História, e de preferência, em arquivo. Não me sentia nem um pouco inclinada ao ensino. Mas os caminhos eram novos e eu precisava trilhá-los à maneira do lugar.

Percorri os caminhos do ensino secundário quando surgiu a oportunidade de concurso público para docente no departamento de História na Universidade Federal de Rondônia. O Concurso era na área de História Regional e, de alguma maneira, me vi impelida a tentar por alguns motivos: a possibilidade de retomar minha trajetória de pesquisa em História; das possibilidades que o Ensino Superior representava na minha carreira como docente; a oportunidade de estudar pontualmente os temas regionais e, também, porque queria compartilhar da construção de uma universidade que se fazia nos porões, mais especificamente, na sala 18, no prédio central. Ali se reuniam os professores que estavam fazendo pós-graduação e que aos poucos se constituíram num 
grupo de estudos que deu origem aos principais grupos de pesquisa em ciências humanas que atuam, hoje, na universidade.

Um desses grupos é o Centro de Hermenêutica do Presente ${ }^{4}$, do qual faço parte desde 1996, antes mesmo de ter me tornado docente, em 1997. Fazer parte do Centro de Pesquisa e me tornar professora da Universidade me puseram em contato com os estudos sobre o lugar e com a história oral. Esses dois encontros foram definidores do rumo que tomei, pois foi com a história oral que encontrei sentido em estudar o meu novo lugar.

\section{A Escolha do Tema e a História do Projeto}

A escolha pelo tema nordestinos na Amazônia se justificava não só pelo fato de eu mesma ser uma nordestina que migrou para a Amazônia, mas porque essa temática é geradora de uma linha explicativa sobre a colonização e ocupação do lugar, que consideram os dois momentos da migração nordestina para Amazônia, o primeiro no final do século XIX, motivado pela seca, caracterizando-se como uma migração familiar e sertaneja, e a segunda, no período de 1943 a 1945, motivada pela chamada "Batalha da Borracha" em decorrência do envolvimento do Brasil na Segunda Guerra Mundial, como processos migratórios efetivos, planejados e incentivados pelo governo dos respectivos períodos e que foram responsáveis pela produção do espaço dessa região ${ }^{5}$.

Durante os anos de 1942 e 1945, cerca de 60 mil pessoas foram enviadas para os seringais da Amazônia (Benchimol, 1965/1977/1999; Neces, 2004). Considerando o que nos diz Ferreira(2), que a "história oral nasceu e se desenvolveu extremamente vinculada a problemática dos estudos das identidades" (Meihy, 2002:69), as duas questões se aproximavam, o fato da migração nordestina ter sido intensa na região e a possibilidade de trazer a questão por uma outra perspectiva, a dos migrantes.

Cheguei ao tema inicial do meu projeto, "História Oral de Nordestinos na Amazônia", por vias tortas. Em 1996 entrei em contato efetivo com a história oral através de textos que me eram enviados por Alberto Lins Caldas, que estava fazendo seu doutorado em Geografia Humana na USP

\footnotetext{
${ }^{4}$ O Centro de Hermenêutica do Presente foi criado partir de 1996 e é constituído por professores e alunos da Universidade Federal de Rondônia (UFRO), que desenvolvem atividades acadêmicas e de pesquisa que tem como referência a Hermenêutica do Presente, crítica desenvolvida pelo Prof. Alberto Lins Caldas. Os vínculos entre a perspectiva teórica da Hermenêutica do Presente e a prática de pesquisa tem sido concretizada a partir de uma dada história oral, que tem como teórico principal o Prof. José Carlos Sebe Bom Meihy (USP).

${ }^{5}$ Essa linha explicativa pode ser encontrada nos trabalhos de Benchimol $(1977,1992)$; Medeiros Filho e Souza (1983); Martinello (1985); Silva (2000) e Neces (2004). E gostaria, também de esclarecer que quando me refiro a produção do espaço, me refiro à aqueles gerados pela colonização como programa governamental e pela migração, nesse caso nordestina, e não os espaços definidos pela população do lugar, como os povos indígenas e ribeirinhos.
} 
e cursando uma disciplina na História, ministrada pelo Prof. José Carlos Sebe Bom Meihy, intitulada: "História Oral, Memória e Relações Disciplinares".

Ao mesmo tempo, tomei conhecimento de uma Comunidade administrada por Freiras Marcelinas, um lugar diferenciado não só pela sua formação forçada, a partir de uma doença historicamente conhecida como doença dos impuros, a Lepra, mas por reproduzir espaços de convivência diferentes num mesmo lugar: o hospitalar, o religioso, o escolar, o de lazer e as moradias. O passo seguinte foi a elaboração de um Projeto de história oral, nos moldes do Manual de História Oral (Meihy, 1996), que foi o primeiro dos muitos textos que me foi enviado e que possibilitou a elaboração do Texto de pesquisa, já considerando os procedimentos e conceitos que ele trazia e que eram inovadores no sentido de diferenciar a pesquisa em história oral da pesquisa com fontes orais.

O Projeto intitulava-se: "Cidade dos Excluídos: História de Vida com Moradores da Comunidade Santa Marcelina"6 e o objetivo geral era compreender os modos de vida de pessoas que vivem forçadas numa comunidade em torno de uma instituição localizada na BR 364, sentido Cuiabá, entre as cidades de Porto Velho e Candeias do Jamari, no Estado de Rondônia, onde funciona uma escola, um Hospital, uma pequena área residencial na entrada da comunidade e mais quatro pavilhões, onde moram pessoas que foram hansenianas e perderam suas famílias ou foram abandonadas, tendo como alvo exatamente essas pessoas que moram na comunidade. Esta "colônia"7 serviu para discutirmos se havia realmente uma percepção sobre o confinamento familiar e social sofrido e principalmente, para compreendermos qual a visão de mundo e as expectativas de vida dessas pessoas.

Foi nessa comunidade que conheci meu colaborador: Adálio Pereira de Oliveira, ex-soldado da borracha, hanseniano, poeta, um narrador que se predispôs a contar sua história de vida. Das conversas iniciais com Adálio nasceu o projeto de história oral com a comunidade e ao mesmo tempo, o de estudar nordestinos, ex-soldados da borracha, em programa de pós-graduação.

“A Jornada do Herói: História Oral com Ex-Soldados da Borracha” seria o título inicial do meu projeto, que tinha como objetivo estudar o processo de deslocamento de nordestinos para os seringais de Rondônia, feito no Estado Novo, durante a Segunda Guerra Mundial. A esse deslocamento a propaganda oficial denominou de "Batalha da Borracha" e os migrantes que dela participaram foram chamados de "Soldados da Borracha". A idéia era pautar por uma linha de

\footnotetext{
${ }^{6}$ Essa pesquisa recebeu apoio financeiro do CNPq e contou com a colaboração de Ednéia Bento de Souza e Ariana Boaventura, alunas do Departamento de História da Universidade Federal de Rondônia e bolsistas do Programa Institucional de Bolsa de Iniciação Científica no período 2000-2002. Ver também os resumos publicados no Anais do VI Encontro Nacional de História Oral, realizado em São Paulo no ano de 2002.

${ }^{7}$ Colônia é um dos conceitos apresentados por Meihy no seu Manual de História Oral (1996a). Entende-se “ por 'colônia' um grupo amplo que tenha uma 'comunidade de destino' (1996a:53). "Comunidade de destino é aquilo que identifica as pessoas, o motivo, os traços que as reúnem em características afins (1996a: 53-67).
} 
estudo que privilegiasse a narração dos remanescentes dessa migração, os aludidos Soldados da Borracha, buscando, a partir das suas trajetórias individuais como se apresentavam na narrativa a relação entre memória e história, ou seja, como acontecia a apropriação nas suas memórias e trajetórias individuais, dos discursos historiográficos sobre a guerra, a propaganda, o alistamento e a vida nos seringais da Amazônia. Além de identificar as estratégias por eles utilizadas para se apropriarem do estímulo migratório do Estado e delinear os pressupostos oficiais do Estado Novo, que alimentaram a elaboração e a execução da "Batalha da Borracha", como por exemplo: as idéias de Nação, como a manutenção das fronteiras do Território Nacional e ocupação da Região Amazônica se apresentavam nos seus relatos.

Pretendia com esse projeto, partindo da possibilidade teórica da história oral como instrumento capaz de diagnosticar o presente, explicitado por meio de um processo transcriativo (Meihy, 1990, 1991, 1996a), fazer um estudo extenso e profundo sobre a visão de mundo, planos e sonhos dessas pessoas, enfim, dos vínculos subjetivos que impulsionaram a experiência desses homens. Este estudo seria feito através de gravações constituídas num processo de entrevista, com procedimentos específicos de história oral de vida, que consiste na narração do conjunto da experiência de vida de uma pessoa e que tende a ser muito mais subjetiva, onde o colaborador é o sujeito primordial da pesquisa e, na qual, tem maior liberdade de dissertar livremente sobre sua vivência pessoal (Meihy, 2002: 130-131). O Colaborador primordial da minha pesquisa foi Adálio Pereira de Oliveira.

Esse percurso de quase sete anos faz parte de um outro: o desenvolvimento de uma certa história oral que orientou e norteia as pesquisas desenvolvidas no "Centro de Hermenêutica do Presente", na Universidade Federal de Rondônia. A linha de história oral que desenvolvo tem antecessores: Lewis (1959), Viezzer (1984), Burgos (1987), Porteli (1993, 1994, 2001), Patai (1991) e Meihy (1990, 1991, 1993, 1996ab, 2004), este bem mais perto de nós, que redimensiona o papel do entrevistado, colocando-o no centro da pesquisa não mais como simples depoente, mas como colaborador ${ }^{8}$, participante imprescindível, sem o qual o trabalho não seria possível e com quem "pudemos repartir as responsabilidades" (1990: 22); e com procedimentos de entrevistas que tentavam por em prática a narração livre.

Essa perspectiva de história oral na qual atuo, explora as relações entre memória, história, narrativas e texto, redefinindo as relações entre passado-presente, onde as narrativas são construções localizadas dos sujeitos. Levando-se em consideração, não somente as informações contidas nos

\footnotetext{
${ }^{8}$ O Conceito de Colaborador, estabelecido por Meihy (1990: 22; 1996a: 53), propõe reposicionamento do entrevistado, que deixa de ser informante, ator social ou objeto de pesquisa e passa a ser a pessoa que aceitará ser entrevistada, ocupando papel preponderante na pesquisa, sem os quais a mesma não seria viabilizada, interferindo na feitura do texto em todos os seus estágios.
} 
relatos, mas o próprio modo de narrar. Daí a importância de nos atermos ao momento da entrevista com cuidados éticos que garantam ao colaborador o "espaço para que sua história seja encadeada segundo sua vontade e condições" (Meihy, 2002;131; Caldas, 1999: 124), e dessa maneira, escolher por onde e como gostaria de narrar, sem impor a temporalidade e a organização narrativa do pesquisador, não tendo essa perspectiva nada a ver com uma pretensa não interferência, pois a história oral ao se desenvolver como um diálogo assume a relação entre o oralista e o colaborador.

Cabe esclarecer nesse ponto algumas questões envolvendo voluntarismo, estímulo e tom vital.

Em primeiro lugar, o voluntarismo se dá porque é o colaborador que escolhe por onde quer começar a contar sua experiência, mas dessa escolha não estamos excluindo ou apagando o contexto em que a entrevista aconteceu, a presença do gravador e mediação do oralista. Tudo isso, é claro, interfere nessa escolha. Essa opção por fazer com que o colaborador construa sua narrativa não é ingênua, mas sim postura diante do que queremos ao realizar tal entrevista: queremos que as narrativas tenham personalidade, que elas apresentem inícios diferentes, percursos de acordo com a trajetória da vida estabelecida a partir do contar do colaborador e não entrevistas onde se pode "adivinhar" as perguntas que cortaram os textos, as emendas, que mesmo depois da textualização aparecem, porque se repetem exaustivamente em todas as entrevistas apresentadas. Não partimos de perguntas por que não queremos informação sobre algo, queremos compreender como o nosso colaborador articula a narrativa sobre sua vida.

Dito isto, fica claro que o estímulo existe durante todo o processo, afinal é para o oralista que a entrevista será dada, é entre oralista e colaborador que se dará o diálogo e não há incoerência entre o voluntarismo e o estímulo, pois o que teremos é resultado de um processo transcriativo, que se inicia desde a elaboração do projeto até a recepção pública das narrativas (Caldas, 1999: 71-79).

Essa história oral, que era inicialmente um "locus multidisciplinar federativo" (Meihy, 1996b: 48-55), vai apresentando-se como um conhecimento autônomo e radical (Meihy, 2003: 31-41), exigindo cada vez mais uma postura teórica diferenciada e geradora de um tipo de leitura e de interpretação não somente novas, mas próprias da história oral diante dos textos transcriados nesse processo. Entre o primeiro texto que define a história oral como "locus multidisciplinar federativo" (1996) e o texto "Radicalização da História Oral" (2003), temos as cinco versões do Manual de História Oral (Meihy, 1996; 1998, 2000, 2002, 2005), através das quais podemos perceber a mudança no estatuto dessa história oral.

No primeiro Manual a História Oral já é apresentada como um conjunto de procedimentos específicos que vai desde a elaboração do projeto até a devolução pública do trabalho, se diferenciando dos trabalhos com Fontes Orais. A entrevista já apresentava papel preponderante no 
trabalho e isso se notava a partir dos conceitos sistematizados por Meihy: de Colaborador, Colônia e Rede e ao estabelecer etapas operacionais para a construção do documento em história oral: préentrevista, entrevista propriamente dita, transcrição, textualização, transcriação, conferência, carta de cessão, publicação e arquivamento. Nesse ponto já se assumiu uma percepção diferenciada da importância da entrevista ao constituí-la em colaboração, e por redimensionar o papel do entrevistado. Mesmo assim, o Manual apontava para outras possibilidades de trabalhos com entrevistas, aliás essa marca se manteve nas edições seguintes.

Do segundo Manual para o quarto, aparece a preocupação de diferenciar como esta linha de história oral compreendia as relações entre Memória e História; Oralidade e Escrita; Identidade. É um momento interessante porque vai indicar que o conjunto desses conceitos, idéias e preocupações poderiam conferir-lhe um status diferenciado, a partir do estabelecimento de um corpus teórico próprio, diretamente relacionado com suas práticas. Já neste momento, não resta dúvida que não é mais possível pensar na história oral como "mera prática de registros, arquivamentos ou substituição documental"(Meihy, 2005: 9) e que é necessário a construção desse corpus e isso não pode ser feito no modelo editorial de um manual.

Do quarto Manual para o quinto toda essa idéia se reforça e ganha espaço. A parte operacional cede espaço para a apresentação pontual dos conceitos e, pelo menos, dois caminhos se abrem: um que conduz a uma história oral política, atuante, fomentadora de políticas públicas, que diz respeito a um grupo, a uma comunidade, e outra história oral, que abre para os caminhos textuais, para as discussões sobre oralidade, para o trabalho com o indivíduo e a sua experiência, a politicidade da história oral acontecerá em outra esfera, na esfera da consciência, do eu que se diz ao narrar sua experiência de vida e consegue dar sentido a sua existência. E a radicalização está na apresentação da história oral, não mais como um lugar onde todos podem usufruir sem atravessar as fronteiras disciplinares, mas como um Sistema, ela não é mais somente a parte que vai construir o documento, somente a parte procedimental, mas toda a articulação que se compreende desde a elaboração do projeto até a construção de uma interpretação própria.

É a essa concepção de história oral que meu trabalho se filia, especialmente na abertura que ela dá para pensarmos a entrevista enquanto texto transcriado em colaboração. Agora não teremos mais entrevistas, nem documento no sentido positivista, que assim como a "concepção Clássica de Texto", institucional e corrente, como nos diz Barthes "está, evidentemente, ligada a uma metafísica, a da verdade" (2004: 264). Teremos texto no sentido barthesiano do "texto único", integral, como "entrada de uma rede de mil entradas", e não como acesso a um Modelo (1992: 46), que é induzido por uma formação a priori. O texto em história oral como referente de si mesmo (Caldas, 2001: 20) carrega consigo a própria teoria e se abre a múltiplos significados. O texto como 
"intertexto", como "uma prática significante", como "produtividade" e não como produto, mas como teatro de uma produção. Assim tratamos as narrativas em história oral. É preciso marcar a diferença. Não estamos construindo "texto-documento", "entrevistas-documento", mas texto, que difere, aqui, de documento, não somente no nome, mas como postura interpretativa: "é necessário emancipar o status monológico legal da significação e pluralizá-la” (Barthes, 2004: 273), pois estamos encarando as narrativas como "espaço polissêmico no qual se entrecruzam vários sentidos possíveis" (2004: 272/273). Daí esse texto exigir outra postura de leitura, que não as das "disciplinas canônicas” (História, Sociologia, Lingüística, Psicanálise, Antropologia), e, também, que não as despreze, mas que sejam utilizadas "parcialmente, livremente e, sobretudo, relativamente", criando um campo interpretativo "sobredeterminado, plural” (2004: 285). Por isso mesmo, essa história oral, difere das demais que estão integradas a uma disciplina como instrumentos e técnicas, ou como metodologia de pesquisa, "que apenas estabelece e ordena procedimentos de trabalho", mas que "as soluções e explicações devem ser buscadas onde sempre tiveram: na boa e velha Teoria da História" (Ferreira(2); Amado, 1996: XVI), e poderíamos acrescentar, na sociologia, na Antropologia, na Geografia. Essa idéia, que é aceita por boa parte dos historiadores orais brasileiros ${ }^{9}$, reduz a história oral a trabalhos com fontes orais, ou seja, as entrevistas de pessoas, de indivíduos, são utilizadas aos fragmentos para corroborar e justificar suas hipóteses e problemáticas.

Junto com essa trajetória da própria história oral se colocava a questão da História de Vida de Adálio, a forma como ele narrava, e as suas experiências que fizeram com que eu percebesse que minha contribuição se daria no sentido de colaborar com a nova face dessa história oral que se delineia.

Quanto mais entrevistava Adálio, textualizava suas entrevistas, mais me distanciava dos temas: "Era Vargas", "Estado Novo", "Batalha da Borracha" e me aproximava de sua vida, dos seus sonhos, da sua experiência e, nessa perspectiva, essa história oral tendia a se fundar na experiência do indivíduo. E me dava conta da minha própria experiência e como minha trajetória muitas vezes se colava e se descolava da vida de Adálio.

Ele, homem, velho, doente, nordestino, na sua ida para Amazônia deixou mulher, família e na sua narração indica esse trajeto como uma derrocada na sua vida: Eu, mulher, jovem, nordestina, na minha ida para Amazônia construí um lar, uma família, uma vida: ele foi obrigado, não escolheu migrar, eu migrei por livre escolha. Ele foi marcado pela doença e pela dor, e as perdas que teve durante sua vida, são percebidas no seu próprio corpo. A narração de Adálio sobre sua experiência

\footnotetext{
${ }^{9}$ Para verificar os trabalhos dos historiadores orais brasileiros e ver a utilização feita e como de um modo geral se percebe a história oral no Brasil é interessante ler os artigos, textos e resenhas dos encontros nacionais e regionais da Revista da Associação Brasileira de História Oral, os livros organizados por Ferreira e Amado (1996), Meihy (1996), Simson (1997), todos listados na bibliografia.
} 
é emblemática de muitas outras vidas que fizeram esse percurso, diz respeito a histórias de homens comuns, a maioria dos brasileiros, que foram abandonados pelo poder público e esquecidos pelas disciplinas acadêmicas.

A História de Adálio ganha sentido e relevo porque expressa situações comuns aos grupos com os quais ele se identifica: nordestinos na Amazônia, soldados da borracha, hansenianos, e sugere na narração de sua história de vida aspectos importantes para entendermos a sociedade brasileira, o migrante nordestino. E, também, por sua característica narrativa, por esse poder de contar, ela é completa e abrangente pela coleção de fatos, situações, imagens e sensações arroladas na sua narração.

Como nos lembra Eduardo Silva (1997: 15) não podemos considerar novo "o propósito de estudar um homem comum como individualidade pensante", isso já foi feito por Ginzburg (1987) e por Foucault (1984), somente para citar dois importantes trabalhos que fundamentam o próprio "Dom Oba II" (1997). Sem falar nos trabalhos de Viezzer (1984) e de Burgos (1987), que são referências do gênero de história de vida e fundamentam boa parte dos procedimentos de entrevistas dos historiadores orais.

A diferença é que este é um trabalho de história oral que trata da experiência de um sujeito, de um indivíduo único e singular, alguém que viveu efetivamente e que, ao ser narrada, gera múltiplas imagens como se tivéssemos entrado numa sala de espelhos, e desvela-se o verdadeiro fascínio da história oral, o fascínio do vivido do qual nos fala Alberti (2004: 15). Não no sentido que ela mesma apresenta como se esse vivido pudesse colorir o passado e deixar-nos mais próximos, como "memória viva" e sim como dimensão do presente que é o tempo eleito por essa história oral (Caldas, 1999; Meihy, 2004a). E a matéria dessa história oral é a narrativa, que "é sempre e inevitavelmente construção, elaboração, seleção de fatos e impressões”(Meihy, 2005:56), no presente (momento da entrevista) sobre um possível passado (o vivido), e que podem trazer alguns elementos como a mentira e o esquecimento, nos fazendo pensar que além do fascínio, a história oral lida com a nostalgia de um passado idealizado e o idílico de um futuro desejado e imaginado. Sentimentos que ligados às emoções, às paixões e à saudade compõem o que Rubem Figgot (Meihy, 2005:56)) chamou de "a boa narrativa".

Esse percurso que apresentei com o Manual de História Oral, representa a trajetória de uma linha de história oral, dentre tantas outras que são praticadas no Brasil. Vale mencionar, aqui, alguns balanços feitos sobre a história oral brasileira, que podem facilitar a visualização das principais diferenças dessa outra história oral.

O Primeiro balanço é o da Prof. Alice Beatariz da silva Gordo Lang, “História Oral: muitas dúvidas, poucas certezas e uma proposta” (1996), que discute basicamente a diferença 
entre o trabalho com fontes orais e história oral, através de uma proposta de conceituação e a apresentação de uso das entrevistas a partir da sociologia. Neste texto fica claro que o simples uso da entrevista, não configura história oral e que o projeto de pesquisa onde se deve especificar o uso de entrevista é fundamental, bem como os objetivos da pesquisa, que não devem ser pautados "no interesse em comprovar fatos, em acrescentar informações à documentação existente, nem mesmo atestar a veracidade dos relatos, mas conhecer sua vivência e sua versão" (Lang,1996:38). A idéia de que a história oral pressupõe um projeto e que o uso da entrevista vai além do registro documental é ponto pacífico entre os pesquisadores que pensam a história oral como um conhecimento que vai além da técnica de captação de entrevistas.

Na apresentação do livro “Usos e Abusos da História OraP” (1996), as organizadoras: prof $^{a}$ Marieta de Moraes Ferreira e a Prof ${ }^{a}$ Janaína Amado, apresentam uma importante discussão sobre o status da história oral, identificando e caracterizando três linhas de atuação em história oral: uma que vê a história oral como uma técnica, e que nesse caso, não considero história oral, pois estaria mais ligado ao trabalho com fontes orais e preocupada apenas com o registro através de entrevistas; uma segunda, que pensa a história oral como uma disciplina autônoma pois considera que o fato do núcleo central da investigação gera uma série de preocupações, como por exemplo, as relações entre escrita e oralidade, que traz para a cena as trajetórias individuais, reformula a relação sujeito/objeto, elege o presente como perspectiva temporal das narrativas, tem um apelo público que ultrapassa os muros da academia que exige toda uma discussão sobre quem é quem na história oral. Nesse caso, a valorização da narrativa pede, também, caminhos alternativos de interpretação. E uma terceira linha, que defende a história oral como uma metodologia que pode estabelecer e ordenar procedimentos de trabalho, formular as perguntas e suscitar questões, mas não pode resolvê-las - isso cabe ao campo teórico das disciplinas canônicas.

Outro importante balanço é o feito por André Gattaz, no artigo “Meio século de história oral.” (1998). Nesse artigo Gattaz apresenta as várias maneiras de se fazer história oral classificadas em seis "tendências" ou "escolas" que ele chamou de História das Elites; história oral Historicista, História dos Vencidos; Gente Ordinária, história oral Metalingüística e Outras tendências. Essa classificação não segue os critérios historiográficos, nem cronológicos, nem geográficos. Mas baseiase no tipo de assunto/tema/objeto a ser estudado, variando enormemente os usos da história oral e seu status. Para Gattaz, na história das Elites estão os grupos vocacionados ao registro de experiência de pessoas "significantes" da sociedade, da política, entrevistando homens representativos de uma época e um setor social. $\mathrm{Na}$ tendência historicista estão aqueles que acreditam que através das fontes orais pode- se "recuperar" fatos históricos do passado de um bairro, de uma cidade, de uma instituição, de um personagem, de um processo histórico. Os grupos que vêem na história oral a possibilidade de "resgatar" a história dos movimentos sociais ou 
políticos, que foram silenciados, que não possuem registro escrito, ou que tiveram suas histórias distorcidas pela visão da elite, foram alocados na tendência história dos Vencidos. Paralelo aos historiadores dos vencidos, estão aqueles que se voltaram a gente comum, aos marginalizados e que militam uma história oral política que pretende transpor os muros acadêmicos e chegar as "lamas da favela e ao contato com o lumpesinato" (1998: 34), fazendo a história oral da gente ordinária. $\mathrm{Na}$ tendência história oral Metalingüística encontram-se os pesquisadores que estão mais preocupados com o depoimento oral em si, do que com a informação neles contidos. Para esse grupo, importa a forma, a maneira como foi dita e contada a história, e consideram a narrativa como uma construção da memória. Em "outras tendências" o autor colocou aqueles grupos preocupados com a criação e manutenção dos arquivos orais e a vertente biográfica que busca através dos testemunhos a vida de um personagem, geralmente público, mas não necessariamente vinculado às elites.

Há muitas maneiras de se fazer história oral, e na ânsia de filiação da minha prática identifico alguns pressupostos básicos que diferenciam e destacam essa maneira "nossa" de fazer, e por isso mesmo, reivindicamos uma "outra história oral":

Em primeiro lugar, o fato de privilegiarmos a narrativa do colaborador como núcleo documental principal nos nossos trabalhos, onde a preocupação com a constituição desse corpus narrativo exige uma postura diferenciada diante do nosso entrevistado. Mais do que a mudança de sujeito-objeto para sujeito-sujeito, praticamos a colaboração, onde o sujeito se transforma em colaborador cuja fala será construída e autorizada por ele. Nossa interferência se dará num nível de mediação e não mais de autoria do texto.

Em segundo lugar, a preocupação com a devolução dessa história oral, que nos remete às perguntas que Meihy nos faz em seu manual: história oral de quem? para quem? por que? E como? sugerindo um comprometimento político com os colaboradores envolvidos na pesquisa e propondo uma história oral pública que ultrapasse os muros acadêmicos e que seja geradora de políticas públicas.

Em terceiro lugar, a maneira como apresentamos os resultados das entrevistas, de maneira sempre integral, um texto transcriado, em contraposição ao uso fragmentado das narrativas. Esse modo de apresentar as narrações das histórias de vida dos colaboradores, completa e dá sentido à idéia de colaboração e mediação. Com as histórias integrais vislumbramos mais e melhor as possibilidades de interpretação, e dimensionamos a importância do tema ou assunto que queremos tratar, na fala do colaborador.

Em quase todas as experiências de história oral no Brasil, seguindo qualquer um dos balanços acima, ou qualquer "tendência" ou "escola", o uso da entrevista é fragmentário, é aos pedaços, sem possibilidade de contextualização na fala que originou o fragmento. Pois muitas vezes 
só se transcreve e textualiza (mesmo sem estar explícito que esse procedimento é praticado), o fragmento da narrativa que será usado. O que não faz parte dos "objetivos" e "interesses" da pesquisa é descartado. Daí, também, o descaso na conferência e na autorização de uso das narrativas.

Com o procedimento transcriativo assumido, o retorno ao colaborador com o texto final, para sua leitura, negociação, colaboração e aprovação, é inevitável. É a parte final do processo que iniciou-se no primeiro contato. E a sua apresentação/publicação de maneira integral no trabalho torna-se imprescindível para essa história oral, que se pretende pública e comprometida com o outro e com a comunidade pesquisada.

\section{A Comunidade Santa Marcelina e o Encontro com Adálio}

A Comunidade Santa Marcelina ${ }^{10}$ é uma instituição localizada na BR 364, Km 17, sentido Cuiabá, entre as cidades de Porto Velho e Candeias do Jamarí, no Estado de Rondônia, administrada por Freiras Marcelinas, na qual funcionam a Escola Municipal Dr. Marcelo Cândia ${ }^{11}$, o Hospital Dr. Marcelo Cândia ${ }^{12}$. Nela há também uma capela ${ }^{13}$, um refeitório com uma cantina, uma oficina ortopédica ${ }^{14}$ e uma pequena área residencial na entrada da comunidade ${ }^{15}$, onde moram famílias de ex-hansenianos e ainda mais quatro pavilhões, onde vivem pessoas que foram hansenianas e perderam suas famílias ou foram abandonadas lá, quando deram entrada para tratar da doença.

Essa Comunidade possui as mesmas características das instituições que começaram a ser criadas no Brasil, a partir dos anos 1930, como instrumentos de controle e confinamento, na campanha de erradicação da hanseníase (Gomide,1991). Foram edificadas em todo o país instituições "amparadas num discurso caritativo, higienista, profilático e nacionalista. Duas categorias de instituições foram construídas: de um lado, os hospitais colônias, voltados à reclusão dos doentes; de outro, os estabelecimentos preventoriais, destinados à sua prole sadia" (Mattos, 2002). A Comunidade Santa Marcelina, surge inicialmente como "hospital colônia", mas atualmente, possui, também, aspectos dos chamados "estabelecimentos preventoriais".

\footnotetext{
${ }^{10}$ Ver Foto 1,2 e 3

${ }^{11}$ Ver Foto 4

${ }^{12}$ Ver Foto 5

${ }^{13}$ Ver Foto 6

${ }^{14}$ Ver Foto 7

${ }^{15}$ Ver Foto 8
} 
O cotidiano de cada uma dessas instituições é diferente, sendo a doença uma forte ligação entre elas. No setor residencial moram pessoas que chegaram com suas famílias acometidas pela hanseníase e não tinham onde ficar. Foram admitidas como funcionários, trabalham no Hospital, na Escola ou no Refeitório e receberam casa para morar. São ao todo catorze casas que se localizam na entrada da Comunidade, formando um corredor com sete casas de um lado e sete casas do outro. A maioria dos residentes nas casas são viúvas que moram sozinhas ou com seus filhos e netos. O Hospital atende, hoje, a comunidade e moradores da cidade de Candeias do Jamari, município vizinho da cidade de Porto Velho. A especialidade do hospital não é mais a hanseníase. Desde a década de 1970 tornou-se um Hospital Geral, com algumas clínicas especializadas em oftalmologia e ginecologia-obstetrícia. O hospital se localiza entre a moradia das Irmãs Marcelinas ${ }^{16}$, a Igreja, os Pavilhões e as antigas Residências dos Médicos. O Refeitório que fica de frente para o hospital serve aos internos dos pavilhões e possui uma lanchonete com atendimento aos usuários, acompanhantes dos internos e visitantes. A Escola, que funciona logo após as casas da entrada, é pública e atende as crianças da Comunidade Santa Marcelina e do entorno. Os pavilhões ${ }^{17}$ ficam no final da Comunidade, logo após o hospital, sendo área mais restrita. São quatro pavilhões; três onde moram os internos, todos eles homens e, o outro, fica mais ao centro, onde funciona a sapataria e a oficina de próteses. Ao fundo, depois dos pavilhões, há um salão ${ }^{18}$ com televisão, mesas, cadeiras, um espaço de convivência. Cada pavilhão possui um banheiro coletivo, cozinha coletiva e enfermaria, além dos quartos, onde vivem pelo menos duas pessoas. Os quartos são bem modestos, cada um deles com duas camas, uma mesinha separando-as, um guarda-roupa e duas ou três cadeiras.

É importante a descrição das dependências desse lugar porque foi num desses pavilhões que conheci Adálio Pereira de Oliveira ${ }^{19}$. Estava tomando seu medicamento diário na enfermaria do Pavilhão onde morava. Ajudei com a cadeira de rodas e o levei para seu quarto que ficava no mesmo corredor. Ele vestia um pijama listrado, estava com a camisa desabotoada. Seus olhos estavam vivos, alegres e claros, mostrando toda sua expectativa e espanto: "Sou eu que vou falar? Vou poder falar o que eu quiser? Então tá bom.” Já no seu quarto passou sem ajuda da cadeira de rodas para a cama. Sua perna direita havia sido amputada logo abaixo do joelho. No outro pé o zelo: um sapato preto bem engraxado. Suas mãos são atrofiadas. Enquanto falava esfregava uma na outra e ao sorrir (faz isso com freqüência), batia palmas e depois passava as mãos nas pernas. Quando contava algo que o deixava envergonhado, levava as mãos ao rosto, cobria o parcialmente e soltava uma boa risada. Apesar das deformidades nas mãos, Adálio tocou violão e num momento durante as entrevista, cantou uma toada que fez sobre sua vida e outra que fez para o Lula, atual Presidente.

\footnotetext{
${ }^{16}$ Ver Foto 9

${ }^{17}$ Ver Fotos 10/11

${ }^{18}$ Ver Foto 12

${ }^{19}$ Ver Foto $13 / 14$
} 
Adálio contou-me que é filho de Vicente Pereira de Souza, nascido em Grossos - Município de Aurora-CE, e de Inácia Pereira de Oliveira, de Pajeú das Flores-PE. Nasceu em Aurora-CE (19/04/1923), é Católico; tinha, no tempo da primeira entrevista (1998), 75 anos. É aposentado pelo FUNRURAL, mas já foi soldado da borracha, caixeiro de loja, agricultor. Cursou até o $3^{\circ}$ ano ginasial, chegou na comunidade Santa Marcelina pela primeira vez em 05 de abril de 1978 e saiu em 09 de janeiro de 1979, voltou, definitivamente, em 19 de março de 1997, quase um ano após a morte da sua segunda mulher. Lá permaneceu até 2001, quando saiu para morar num quarto alugado em Candeias do Jamarí. Era seu sonho maior sair da comunidade, conseguir uma prótese e deixar a comunidade. Apesar das irmãs "serem boas e generosas", ele não agüentava a dependência. Foi nas dependências desse quartinho alugado que fizemos a última conferência da sua narrativa, em Maio de 2005.

Mas essa história foi contada por ele mesmo, do jeito que ele quis, por onde quis começar. A narrativa de Adálio fluiu, ele estava disposto a contar e cantar. Sabia da experiência que podia e queria dispor, como se já nos esperasse. A sua "faculdade de intercambiar experiências estava intacta" (Benjamin, 1994: 198). Ele é um narrador do tipo que Walter Benjamin reclamava estar se perdendo porque as ações da experiência não eram mais consideradas. Adálio é um pouco o "camponês sedentário", tendo sido, também o "marinheiro comerciante", exemplos de tipos de narradores benjaminianos. Fez uma longa viagem, atravessou o sertão e o interior do país até a Amazônia e lá se fixou. Carrega consigo as experiências do viajante e do homem do lugar. Isso faz dele um narrador especial, pois ele intercambia esses dois tipos de narradores e, como disse Benjamin: "A figura do narrador só se torna plenamente tangível se temos presente esses dois grupos [o camponês sedentário e o marinheiro comerciante]" (1994: 198).

Adálio é um narrador, fez uma canção para não esquecer o que viveu. Teve um grande prazer em me contar a sua história de vida e se sentiu estimulado a fazê-lo quando percebeu ter encontrado interlocutores que estavam interessados na sua vida, foi como se ele tivesse se preparado a vida inteira para contar. Por seu isolamento e solidão não pôde ser inserido numa tradição nordestina de cantadores que se utilizam do cordel, dos martelos e dos repentes para narrar suas experiências de vida como Patativa do Assaré (2000), ou como contadores de histórias. Apesar de trazer, claramente, nos seus versos, a influencia desse canto. Sua narrativa também não se insere no gênero dos testemunhos, como Domitila (Viezzer, 1984) e Rigoberta (Burgos, 1987), ou mesmo de escritores populares, como Carolina Maria de Jesus (Meihy, 1994; 1996). Não é também o Moleiro do “Queijo e os Vermes" (Guinzburg, 1987), nem o homem livre de cor do "Dom Oba II" (Silva, 1997), nem o degolador "Pierre Riviere" (Foucault, 2003). O texto-Adálio reúne aspectos desses personagens e poderia ser transformado e adequado a qualquer um dos gêneros acima citados, mas isso seria forçar a sua entrada no "grande livro" (Deleuze; Guattari, 1997), adequar seu discurso para 
que ele se filie como uma folha, a um galho da árvore da "grande narrativa da história", cooperando com o processo de encontrar, no discurso linear da História Universal, um lugar para aquele outro, sempre numa tentativa de assimilação e eliminação das diferenças (Bhabha, 1998). Contextualizar sua fala para ela poder significar. Então, o significado está para além, fora e antes da narrativa de Adálio? É exatamente o contrário que estamos propondo para pensar Adálio. O texto produzido em colaboração por essa história oral possibilita essas leituras, mas clama por uma nova interpretação que flua da própria narrativa, os temas serão discutidos na medida em que aparecem na palavra contada de Adálio e não como perspectiva a priori, ou seja, a narrativa de Adálio possibilita uma leitura sobre o cotidiano e a vida nos seringais da Amazônia durante a segunda guerra mundial, possibilita uma leitura sociológica sobre a hanseníase e seus estigmas (Claro, 1995). Possibilita, também, uma leitura psicológica de um homem que perdeu tudo ao longo de sua vida, inclusive seu próprio corpo. São muitas possibilidades que podem e devem aparecer como pontos importantes da leitura que pretendo realizar, mas elas devem vir dimensionadas na própria narrativa e desenvolvidas segundo o prazer (Barthes, 1977a/ 1984), e as afinidades do oralista.

Os temas que podem ser trabalhados a partir da narrativa de Adálio estão ligados à maneira de lembrar, a relação entre o oral e o escrito, e a forma oral que se quer narrar. Isso é importante porque estou trabalhando com um conhecimento, a história oral, onde a transposição do oral para o escrito é fundamental. É nessa passagem que se estabelece, num processo de transcriação, o corpus textual no qual nos debruçaremos. É impossível recuperar o acontecido, então o que temos a partir das entrevistas, do que o colaborador nos conta é momento narrativo, e não relato sobre o que realmente aconteceu, transformando as relações entre a oralidade e a escrita numa "relação necessária, incontornável no domínio do simbólico" (Orlandi, 1999: 152). Ou seja, aquilo que constituímos em entrevista colaborativa é a maneira como o colaborador está significando sua experiência, como ele simboliza sua vida, como lhe dá organização, naquele momento, naquelas condições específicas, onde e quando se deu a entrevista. Podendo, portanto se modificar, significar diferente, coisas que foram contadas de um jeito, serão contadas de outra maneira, ou mesmo omitidas.

Sendo esse momento narrativo constituído por um modo de lembrar que é fluido e mutável, temos que considerar, também, o esquecimento, o silêncio, as falhas de memória, as mentiras, as versões, como aspectos desse lembrar - que serão identificados, pensados e relacionados no momento da análise e também, no momento da recepção. 


\section{Os Caminhos da Narrativa e as Entrevistas}

Importa pensar como essas reflexões geraram e ao mesmo tempo foram geradas por uma postura metodológica, por uma posição diante do outro, das suas experiências e das redes interpessoais envolvidas. Essa dimensão pode ser medida pela maneira como procedemos nas e com as entrevistas. Aqui também ocorre uma mudança na percepção de um dos conceitos fundamentais da história oral que estamos falando: o de Transcriação.

Para Meihy, até a publicação da $5^{a}$ edição de seu Manual de História Oral em 2005, a transcrição é a última etapa de um processo de estabelecimento do texto que se inicia com o Projeto, passa pela Pré-entrevista, depois pela Entrevista, propriamente dita, levando a uma textualização, até chegar:

... a fase final do trabalho dos discursos. (...) Teatralizando o que foi dito, recriando-se a atmosfera da entrevista, procura-se trazer ao leitor o mundo de sensações provocadas pelo contato, e como é evidente, isso não ocorreria reproduzindo-se o que foi dito palavra por palavra. (...) tem como fito trazer ao leitor a aura do momento da gravação. (...) O fazer do novo texto permite que se pense a entrevista como algo ficcional e, sem constrangimento, se aceita esta condição no lugar de uma cientificidade que seria mais postiça. Com isso valorizase a narrativa enquanto um elemento comunicativo prenhe de sugestões. (Meihy, 1991: 30-31)

Considerando ainda que temos uma fase de efetivação da colaboração, onde fazemos a conferência do texto com o colaborador, e posteriormente, a fase da devolução pública.

Quando iniciei as entrevistas com Adálio, já estava imbuída de uma idéia apresentada por Caldas, que vê a transcriação não como uma das etapas da Entrevista, mas todo o processo como uma "Transcriação Hermenêutica":

... concepção e visão de mundo, não somente de como se produz um texto, mas sobre o fundamento da própria realidade e de como podemos compreendê-la e modificá-la. (Caldas, 1999: 74)

Essa "concepção e visão de mundo" impõe uma busca mais radical pelo colaborador, pela sua experiência e leva a um afastamento do tema que eventualmente tenha motivado inicialmente o projeto, pois ao nos colocarmos em diálogo com o outro, vemos que ele extrapola com sua vivência qualquer categoria, rótulo, rede ou comunidade de destino ${ }^{20}$. E devemos buscar nesse colaborador

${ }^{20}$ Para Meihy a Colônia é definida “... pelos padrões gerais de sua comunidade de destino", que é "aquilo que identifica as pessoas, os motivos, as trajetórias que as reúnem em características afins” (1996: 53); a Rede é “... uma 
através da sua visão particular de mundo a humanização das percepções, aquilo que Meihy (2004a: 40), apontou como sendo a matéria essencial da história oral:

A história oral se apresenta como forma de captação de experiência de pessoas dispostas a falar sobre aspectos de sua vida. Quanto mais elas os contarem a seu modo, mais eficiente será seu depoimento. (2004a: 51)

E "quanto mais elas contarem ao seu modo", mais realizaremos essa história oral que se preocupa com uma percepção do indivíduo, com uma visão singular de mundo, com os sentimentos, as mentiras, os esquecimentos, o sonho, a subjetividade, as redes simbólicas da singularidade, como outras dimensões do conhecimento, que se diferencia daquela que é gerada por estudos de temas, análises estruturais, partidos políticos e de um tipo de trabalho com entrevistas que usam o outro como mero informante ou "objeto" fragmentado para servir ao projeto.

Essa história oral exigiu uma postura frente à entrevista que pudesse deixar fluir essa experiência, esse modo de contar e de narrar a vida. Postura que permitisse que o colaborador pudesse falar mais livremente, sem direcionamentos marcantes, sem imposições de uma temporalidade estranha e dominadora que tornam todos iguais e se sobrepõe às singularidades, sem o pleno fantasma do pesquisador e da sua disciplina, mas de um pesquisador também humanizado, marcando a entrevista apenas com sua presença humana e não mais como um advogado, um delegado ou um cientista. O oralista se separando do historiador oral.

Sempre soube que o fato de estar ali, de ser de uma universidade, e o próprio contexto em que nos encontrávamos daria formato prévio e geraria um tipo de narrativa. Por isso quero deixar claro que não se trata do "mito da não interferência" (Portelli, 1997: 32), ou de uma objetividade às avessas, muito menos de nos colocarmos como os que "dão voz" aos excluídos. Mas ter uma postura que permita que as diferentes temporalidades e concepções de mundo se digam do modo que acharem melhor.

Aqui, a idéia de transcriação retoma seu sentido de origem, transcriar para comunicar melhor o sentido, a intenção. A “tradução” do oral para o escrito não se opera com uma simples transcrição, assim como uma tradução de idiomas diferentes, especialmente quando se trata de um texto subjetivo como a poesia e a narrativa do colaborador. Blanco, em espanhol, não se traduz para branco em português, simplesmente. Essa simples transposição de línguas gerou um texto conjunto de dois importantes poetas Otávio Paz e Haroldo de Campos: Transblanco (1986) e é de onde

subdivisão da colônia e que visa estabelecer parâmetros para decidir sobre quem deve ser entrevistado ou não..." (1996: 53), ou seja, define "colaborador" como uma pessoa que aceitará ser entrevistada e que ocupará papel preponderante na pesquisa, sem os quais a mesma não seria viabilizada. 
Meihy assimilou o conceito de "transcriação". O poema é outro, e é o mesmo, a entrevista transcriada é outra e é a mesma. A transcriação nos aproxima do sentido e da intenção original que o colaborador quer comunicar. Essa história oral é, portanto, "comunicação em presença, a energia, o envolvimento multisensorial que inclui, entre outras, a categoria da fascinação” (Ferreira, 1997:66), da nostalgia, do idílico. E que precisam permanecer na escrita, quando já não existir mais "a presença", "o diálogo".

Nesse sentido, a idéia de transcriação como aquilo que compreende todo o processo norteou os procedimentos da entrevista com Adálio, que se deu de maneira intuitiva. Não sabia exatamente como fazer, mas sabia o que não gostaria de fazer.

1. Não queria fazer uma entrevista dirigida com pergunta e resposta que impõem ordenamentos narrativos e, conseqüentemente, temporais, gerados por perguntas como: "onde e quando nasceu?", “nome do pai e da mãe?”, "profissão?”, que têm como função obter “informação” para complementar dados de pesquisas ao mesmo tempo em que formatam o conjunto narrativo à imagem das "crenças" do pesquisador;

2. Não queria fazer entrevistas com perguntas abertas para esclarecer temas da pesquisa, para saber a opinião das pessoas sobre determinado assunto ou acontecimento histórico, realizando um estudo temático, seja sociológico, histórico, geográfico, educacional, sob o título de história oral temática, que terminaria servindo somente ao pesquisador, sem atingir a plenitude possível do colaborador, realizando na verdade um trabalho com fontes orais;

Daí comecei a pensar na entrevista como diálogo que pudesse ser "aberto ao aconchego, à confidência e ao respeito" (Meihy, 1996a: 55), e colocando-a, como diz Caldas (1999: 99), "em patamar diferente de uma simples técnica", pois não se trata de obter informações, criar documentos, mas de estabelecer comunicação entre pessoas com o único objetivo de compreender (Garret, 1967: 18) com plenitude um outro que, sem nós, sem esta história oral, estaria fadada a não ser uma experiência compartilhada, como é dado aos heróis, aos vencedores.

Essa entrevista gera um tipo de texto que praticamente elimina o primeiro trabalho da textualização que tem como um de seus objetivos transformar a entrevista (pergunta e resposta) em texto fluido, essa operação começa com a:

Anulação da voz do "entrevistador", dando espaço a fala do narrador. [...] Consta desta tarefa a reorganização do discurso, obedecendo à estruturação requerida para o texto escrito. Pelas palavras-chave estabelece-se o corpus, isto é, a soma de assuntos que constituem o argumento. 
Faz parte do momento da textualização a rearticulação da entrevista de maneira a fazê-la compreensível, literariamente agradável. (Meihy, 1991:30)

É bem verdade que essa “ anulação" não é a simples eliminação da voz, das perguntas do entrevistador, mas “inclusão na dialogicidade do texto" Caldas (1998:41), quando isso for pertinente e exigido pela estrutura narrativa. Dessa maneira a textualização não é, também, correção de gramática, passagem da linguagem popular para uma, pretensa, norma culta, apagamento das repetições, junções de temas iguais que se repetem na fala, reordenamento temporal da narrativa em ordem cronológica, mas a transformação da entrevista em texto. Essa transformação exige sensibilidade do oralista em relação ao que o colaborador quer comunicar, e mediar essa comunicação, sem apagar as marcas da oralidade e as características identificadoras da fala do colaborador.

O que pretendíamos nas entrevistas era assumir a participação efetiva no diálogo, mas garantindo ao colaborador a escolha do quê e como gostaria de narrar sua experiência. Pensamos então num tipo de abordagem que garantisse a Adálio perceber que o que gostaríamos de ouvir era sua experiência e não sua "história de vida", ou sua "vida de hanseniano", de "Soldado da Borracha", porque queríamos que essas situações viessem dimensionadas na própria narrativa, como escolha sua e não como imposição temática. Foi dessa idéia que Caldas desenvolveu o conceito de "origem voluntária", que mais tarde e, com a realização de várias entrevistas feitas com essa preocupação, gerou um conceito mais amplo, o de "cápsula narrativa", que foi utilizado nos projetos e nas entrevistas seguintes que realizamos no projeto com a Comunidade Santa Marcelina e exsoldados da borracha. O texto no segundo capítulo: "Adálio Pereira de Oliveira" nasce nesse momento teórico.

Os textos de Adálio são resultados de encontros realizados entre os anos de 1998 e 2000, na Comunidade Santa Marcelina. Ao todo foram 15 encontros para gravação das entrevistas, num total de 6 horas de gravação. Embora tenha ido lá outras tantas vezes apenas para vê-lo.

A primeira entrevista durou quase 2 horas, e foi dividida em duas etapas. Na primeira etapa Adálio falou livremente, escolheu por onde queria começar a contar, essa parte é o que se transformou no que estou chamando de "a jornada". A segunda parte foi estimulada, perguntamos a ele do que ele gostaria de falar mais, de aprofundar, e ele nos deu o tema da escola e dos estudos e depois perguntamos sobre a doença, percebi que esse era um assunto que o incomodava, esse tema foi retomado por ele na entrevista sobre "a música".

Depois marcamos um novo encontro e propus que conversássemos sobre “os sonhos" dele. A entrevista sobre sonhos rendeu dois encontros e mais uma hora e meia de gravação. 
A essa altura já sabíamos das suas composições, de que ele cantava e tocava violão. Combinamos então um encontro só para falarmos sobre a música e para que ele as tocasse para nós. A etapa da música se desdobrou em muitos outros encontros e trouxe para Adálio e para mim muita satisfação.

Passei com ele dias, corrigindo a transcrição das suas composições. Eu trazia a transcrição, lia com ele, corrigia algumas palavras, deixava com ele e no encontro seguinte ele me entregava com as suas correções. Eu levava para casa passava as correções dele para o computador, imprimia e devolvia para ele novamente, até que ele dizia: “Agora tá certo!”

Ele ficou radiante quando levei para presenteá-lo um livrinho caseiro, feito com recursos de computador, com a letra da música sobre sua vida. Na capa imprimi o título da música dado por ele mesmo: "A História de um Nordestino na Amazônia" e o seu nome, "Adálio Pereira de Oliveira" e, no miolo, os seus versos. Imprimi dez cópias para entregar a quem ele tivesse vontade e ele fez isso com muita satisfação e orgulho.

Posso dizer que os temas foram negociados, pois numa entrevista sempre há o que desejamos saber e o que nos é contado, e estão apresentados pela ordem das entrevistas realizadas.

A primeira entrevista corresponde à primeira parte da "Palavra Contada": a jornada. Essa parte é o que estamos considerando a "narrativa primordial" e da qual decorrem todas as outras, que são os aprofundamentos temáticos, entrevistas geradas por temas e assuntos dessa primeira narrativa: os sonhos, a escola. E por fim uma segunda parte que veio com tal força que se tornou a "Palavra Cantada" que são as narrativas de sua experiência com a música e a poesia. Além de conter duas composições suas: "A História de um Nordestino na Amazônia" e a "Música para o Lula" e o desdobramento dessa entrevista é a narrativa sobre a doença, que não foi separada, mas mantida no contexto da sua fala. Foi, portanto, da própria narrativa de Adálio que construí a estrutura da tese e seu título: Experiência e Memória: A palavra contada e a palavra cantada de um nordestino na Amazônia. 
A HISTÓRIA DE UM NORDESTINO NA AMAZÔNIA 
ADÁLIO PEREIRA DE OLIVEIRA

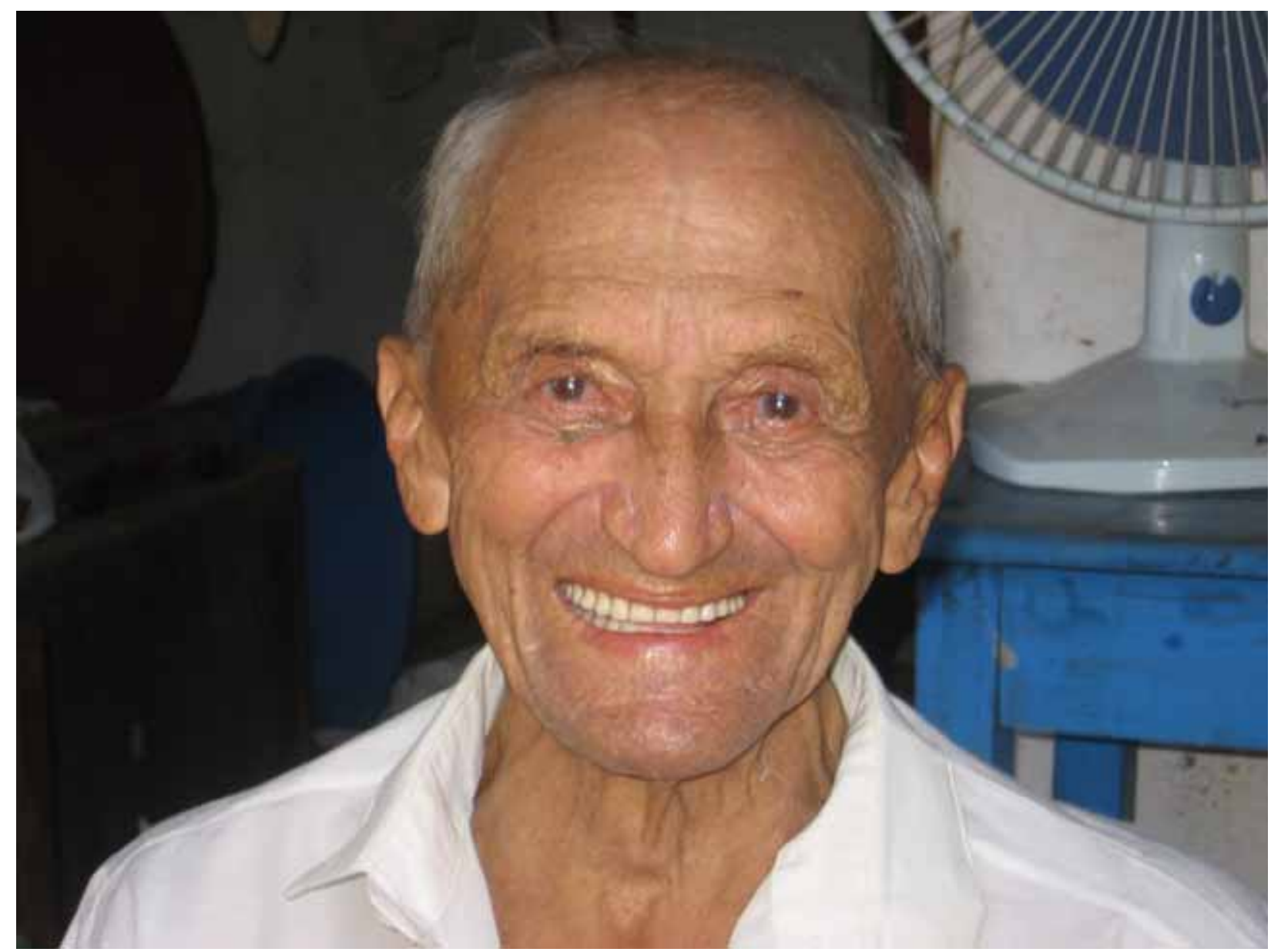




\title{
A PALAVRA CONTADA
}

\section{A JORNADA}

\author{
“Agora eu um homem aleijado de uma perna, o que quê ele faz? \\ Não faz nada! Aqui já tenho uma perna prometida que chamam \\ prótese para botar no lugar! Tiraram a medida um dia desse \\ e agora tem que me chamar pra experimentar, mas ainda não \\ chamaram não e eu estou aguardando. A barra é pesada."
}

Eu saí para cá ${ }^{1}$ em fevereiro de 1943 , por causa da guerra de $1939^{2}$. Nós viemos contratados como soldado da borracha ${ }^{3}$ para o serviço para o americano. E Teve aquele Osvaldo Aranha, que era o primeiro ministro brasileiro que falou nas Nações Unidas, que empatou esse negócio e o presidente Getúlio Vargas não podia entregar o Amazonas para o americano, desapropriar os patrões que eram os donos e depois disso ele ficasse na posse e quando chegasse o fim do contrato ele não queria entregar, aí isso foi abaixo, nós fiquemos, com se diz, bem dizer desamparados no meio do mundo ${ }^{4}$, já no Pará. Eu estava no meio de 35 mil homens. Antes eu morava no Ceará em Cascavel, era uma cidade boa, rica e muito produtiva ${ }^{5}$.

A pessoa naquele tempo tinha era que obedecer! Eu tava casado e não queria vir, mas tinha que obedecer. Mesmo casado tinha que deixar tudo! ${ }^{6}$ E eu deixei minha mulher com seis meses de casado, mas ou ia pra guerra ou vinha pra borracha ${ }^{7}$.

Pra vim pra cá tive que vender tudo, porque o que já se tinha de roupas, calçado, qualquer luxo que a gente tivesse, um relógio, uma aliança, não podia trazer nada ${ }^{8}$. E aí eu recebi uma mala de carregar nas costas com uma rede pequena, uma coberta pequena, um caneco de esmalte e um par de alpercata de rabicho. Uma calça de mescla e uma camisa de um pano ordinário que nós chama americano ${ }^{9}$. Assim era a farda. E um chapéu de palha. E uma carteira de $3^{\text {a }}$ categoria ${ }^{10}$ também. E trazia-se 2 folhas, isso no começo, que era pra entregar uma paro americano que era o contrato e a gente ficava com a outra pra depois saber se o americano tava fazendo o negócio direito, era pra conferir com aquela outra folha.

Aí nós fiquemos encurralado, mas se o camarada voltasse na idade que eu tava, que era na idade de ir pra guerra, não dava porque ir pra guerra era pior; aí eu vim pra cá. 
Cheguei aqui no Amazonas. Primeiro eu cortei muita lenha pra navio. Naquele tempo do atraso $^{11}$ os navios tudo era a lenha. Esses navios de convés baixo era tudo a lenha. E eu cortei muita lenha! Passei um ano antes trabalhando no Rio Purus, fazendo lenha pra navio e trabalhando de todo serviço ${ }^{12}$.

Quando eu vim para o seringal foi em 1944, eu vim cortar seringa. Agora eu só não queria era voltar pra lá porque podia ser convocado. Porque a guerra só veio se acabar em 1945 e eu vim pra cá por causa disso. Faziam a gente vim pra seringa como à guerra, porque se não fosse para seringa ia pra lá. $\mathrm{Na}$ idade que eu tava era convocado mesmo! Agora aquele de idade maior não, vinha porque queria. Eu vim obrigado ${ }^{13}$, vim com medo da guerra ${ }^{14}$.

Aí nós viemos até Coroatá no Maranhão de carro. Agora do Maranhão pra frente nós viemos num trem. Era um trem de carga, com muitos carros, e vinha cheio de muitos homens. Tudinho era soldados da borracha! No meu alistamento foram 75.000 soldados da borracha e veio tudinho pra cá. E o que é certo é que cheguemos em São Luís, onde tive uns dias lá num pouso chamado Maracanã. Adispôs, embarquemos numa barcaça para embarcar num navio maior chamado Itapuí da Companhia Ícaro, lá no meio do mar. Ia levar a gente para Belém ${ }^{15}$. Quando cheguemos num mar mais fundo que tem lá, o submarino se apresentou assim longe de nós uns 4 $\mathrm{km}$. Dentro do mar a gente enxerga longe, num navio de convés alto a gente enxerga longe! Ainda o pessoal do navio deram uns suspensórios para nós com cinturão e aquelas cortiças, quatro cortiças, uma na frente, outra de um lado, outra de outro e uma nas costas, um salva-vidas, onde a gente atacava o cinto nele. Porque tava vendo a hora o submarino botar o navio no fundo, afundar, o submarino chegar, o submarino, que tava ali no fundo. Pediram socorro. Quando o avião vinha chegando, aquele intruso que tava lá no meio do mar, abaixou. O avião jogou uma bomba, mas errou o alvo porque não explodiu, errou! ${ }^{16} \mathrm{E}$ veio mais um caça-mina que é um barco de guerra muito decente, muito medonho, acompanhou nós com uma bóia que tem uma lâmpada que ia apagando e acendendo até mesmo na entrada do Porto de Belém, indo pra dentro da baía de Marajó. Fumos lá pro pouso chamado Tapanã em Belém. Lá quando nós cheguemos com poucos dias já tinha 35 mil homens reunidos lá.

Aí foi que veio essa notícia do Ministro Oswaldo Aranha, que não aceitou o negócio do Presidente Vargas com o americano. O Presidente Vargas tinha dado os seringais todinho pros americanos tomar conta. E nós vinha como soldado para o americano, nós não vinha por conta do governo brasileiro não. A companhia era americana. E o que é certo é que o Osvaldo Aranha chegou lá das Nações Unidas, não aceitou e disse que não aceitava não, porque quando o americano 
empossasse, tomasse conta do Amazonas não queria entregar mais, mesmo com o fim do contrato ${ }^{17}$. Aí foi a baixo e nós fiquemos aí.

Viajei para Manaus num navio chamado Pedro II que é do Lóide Brasileiro. Aí quando cheguemos os patrões do Acre, do Amazonas mesmo, chegava tirava assim: um patrão chegava tirava vinte, outros chegava tirava trinta, outros escolheram gente morena que era mais resistente, por causa do tifo, outros escolheram gente da perna fina, que não eram preguiçoso. Isso tudo acontecia com o soldado da borracha ${ }^{18}$.

E o que é certo é que foi assim e até que foi tudo amparado. E teve uma manada de carioca que adipôis que caiu a companhia americana voltou tudo pra trás, voltaram tudo pro Rio, o governo deu passagem de volta. Eles vinham atrás é de aventura, não era de cortar seringa, mas não sendo pro americano não vinha pra cá nenhum. Eu acho até graça quando lembro disso! ${ }^{19}$

Eu fiquei em Manaus, em Ponta Pelada. Dali foi que os patrões iam tirando os homens, aí chegou minha vez. Eu vim numa manada de duzentos ${ }^{20}$, para uma cidade que tem aqui no berço do Purus, chamada Lábrea. De lá vim trabalhar com um patrão chamado Matias Quaresma que era um dos patrões mais ricos aqui do Amazonas ${ }^{21}$, com relação a seringa. Vim trabalhar com ele e na turma que eu vim, veio uns sessenta. Tudo pra esse patrão. Desses alguns foram aproveitados para um serviço mais maneiro ${ }^{22}$, mas a maior parte foi tudo pra seringa. E eu fui pra uma colocação de seringa chamada Rarizal, cortar seringa ${ }^{23}$. Ele mandou um homem me ensinar, que eu não sabia cortar, não sabia defumar. O serviço é um pouco enrrascado! Tem de riscar, bota a escada em pico, aí o camarada roça pra ficar o piso limpo não ter toco, depois vem o fiscal, que é da casa limita ali o tanto de tigelinha, aquelas canequinhas, que pode a seringa pegar de madeira. Um dois homens bota abaixo três tigelas, e quando tinha que ser direito um traço e botava uma polegada só. Aí botei aquela caneca, o camarada ficava já fraquejado, aí começava produzir.

Nos primeiros anos a pessoa nunca faz nada, sempre apanhando porque o serviço é um pouco dificultoso! E ainda tem um tal de paludismo aqui, que hoje em dia é chamado de malária, quando agarrava a pessoa, o camarada tremia uma hora, bolando assim no meio da mata. E se ele não fizesse a borracha no fim do mês o patrão também não vendia ou ele morria com a malária ou de fome. A sujeição era essa! E a gente era obrigado a trabalhar a noite. E assim a pessoa vai sofrendo, muitos morreram, mas eu sofrendo muito atravessei ${ }^{24}$

Daí cortei seringa nesse seringal, tirava Sábado baixava pra Manaus, o escritório do meu patrão era em Manaus, ali na Rua Marcílio Dias. Ele lá pagava todo sábado o que a gente tirava corretamente. Eu sei que eu voltava pro mesmo seringal de novo e ia trabalhar. E assim quando foi 
uns anos aí que eu não tô bem lembrado o meu patrão morreu. Aí ficou mais difícil! Eu fiquei trabalhando pra um afilhado dele, mas já uma coisa assim com pouca garantia. Aí ele inventou de ser prefeito em Lábrea. Eu digo: "bem, o senhor indo ser prefeito na Lábrea aqui no seu seringal eu não fico mesmo". Fui trabalhar com ele. Porque eu não me dava muito com o gerente geral que tinha ali, ele não era boa pessoa.

Depois eu saí do seringal de lá e vim trabalhar aqui pro Acre. Trabalhei num seringal chamado Porto Rico. Lá também fiz muita borracha! Cansei de produzir ${ }^{25}$ até duas toneladas por ano ${ }^{26}$. Agora aí o patrão quando dá fé essa casa que eu tava trabalhando quebrou, ainda ficou um saldo lá para me pagarem e não pagaram. Saldo pouco, dinheiro pouco. O patrão forte quebrou. Me mudei pra outro e aí fui assim bolando e sofrendo! ${ }^{27}$

Vim pra outro seringal chamado Novo Acordo, essa BR 364 que vai pro Acre passa lá. Trabalhei com um patrão chamado João Barbosa. Ali eu me dei bem! Comecei a trabalhar, o patrão pagava bem um saco. Esse homem se desnorteou, se desmantelou e também foi abaixo. E assim eu fui, também ${ }^{28}$. E baixava pra Manaus também, era o sistema.

Pra vim pro Acre ou pra cá, naquele tempo era atrasado, não dava! E assim Manaus era uma capital do Estado era melhor a gente ficar lá do que ir pra uma capital de território. Aí eu fiquei trabalhando, até 1976 eu cortei seringa!

Vim pra cá pra beira do Rio Madeira, comprei um lugarzinho com uma economiazinha que eu tinha e estava morando agora de sitiante e tava muito bem ${ }^{29}$. Eu cheguei lá no dia 26 de setembro de 1977. Tá com vinte anos que eu trabalhei lá e esse lugar é meu ${ }^{30}$. E o meu lugarzinho tem uns quinhentos metros de frente, 1400 de fundo. Mas na entrada não deu de fazer a casa porque tem uma água, com 150 metros tem uma água. Aí fui fazer a casa mais na frente, no meio do lote porque lá a terra era alta! E fiz essa benfeitoria. Mas, eu trabalhei esses vinte anos lá todo tempo. E esse lugar é meu! $!^{31}$ Fiz muita plantação, e ainda tem muita plantação. Mas quando foi num dia que eu vim aqui para cidade, tinha uns camaradas que tava enfezando, botando animal porque pra lá ninguém trabalha e quando tem um que trabalha eles fica de cima, perseguindo, soltando animal dentro do meu lugar pra estragar ${ }^{32}$.

Porque tinha muito milho, macaxeira e plantação como laranja, biribá, esse limãozinho nosso legitimo e cupuaçu, e muita mangueira, coqueiro. Tudo isso eu deixei plantado lá $a^{33}$. Aí vim aqui no Porto Velho receber meu saldo, que sou aposentado pela Funrural, recebo um salário mínimo e eu recebo ali naquele Banespa lá na rua Sete de Setembro em Porto Velho. E eu ia comprar uns 
cartuchos de bala pra eu me garanti mais. Eu queria atirar nos animais e até em gente se fosse preciso, porque eles queriam invadir o que era $\mathrm{meu}^{34}$.

E o que é certo é que eu vinha na "Caça e Pesca" na Rua Sete de setembro, comprei uns cartuchos e levei pra casa, mas aí eu carreguei um volume de uns 36 quilos na costa, 800 metros pra ir pra casa, mas esses oitocentos metros já era dentro do meu terreno, aí saiu uma borbulha assim do lado do meu pé direito. Deu uma tal de infecção e aí eu vim pra cá ${ }^{35}$ no dia dezenove de março de 1997, dezenove de março que vem agora, 1998, vai fazer um ano, eu cheguei aqui às oito horas da manhã e quando foi umas cinco e meia da tarde me cortaram a perna ${ }^{36}$. Aí por causa de terem cortado a perna veio gente conhecido me visitar aqui. Aí invadiram tudo e carregaram tudo que eu tinha e eu fiquei sem nada! Só tenho o lugar, a casa também era de pobre, mal construída com assoalhado de açaí e coberta de palha de babaçu ${ }^{37}$.

E daí pra cá eu tô vivendo aqui nessa comunidade. E sempre me dando bem! O povo aqui coopera bem com a pessoa. A gente tem um café pela manhã com pão, tem o almoço, tem a janta, tem roupa lavada, também tem a cama pra dormir. E eles assisti bem com o remédio. E se a pessoa que tá aqui no pavilhão se ele adoecer aqui levam pro hospital porque lá é aonde os doutor convivem e os enfermeiros, aí gente tem uma assistência medonha!

Eu acho muito bom esse lugar, o pessoal trata bem da gente! É um povo muito bom, legal. As irmãs são boas, os doutor também são muito popular, são bom ${ }^{38}$. Agora aqui o fracasso mesmo foi só o meu! $!^{39}$ Porque um homem cortar a perna de uma pessoa é o mesmo que cortar o pescoço e fica a pessoa aleijada para sempre ${ }^{40}$. Esperando uma perna, qualquer dia tiram a medida, mas só vai quando os homens chama. Ainda não me chamaram. E eu sentando nessa cadeira! Me deslocando pra cima e pra baixo ${ }^{41}$.

Agora antes desse tempo ${ }^{42}$ de vim pra cá eu tinha pai e tinha mãe ${ }^{43}$ ! Eu nasci no sertão do Ceará chamado Aurora ${ }^{44}$ ! Nasci lá em 19 de abril de $1923^{45}$. Eu vivia lá! O meu pai não era muito pobre. Lá nós tinha gado, tinha muito animal! $!^{46}$ No sertão quando a gente chama animal já sabe! É cavalo, burro, jumento $^{47}$, essas coisas, agora gado já é outra. Pois aí nós tinha isso tudo ${ }^{48}$.

Quando foi em 1932 houve uma estiagem ${ }^{49}$ pra lá e tava dificultando água para os animais, aí ele vendeu os animais que tinha, o gado e nos mudamos para Cascavel ${ }^{50}$ que é bem perto de Fortaleza no Ceará, são 12 léguas, $72 \mathrm{~km}$ pra Fortaleza. Aí lá nós tava vivendo, mas lá ele ficou com uma bodega, pra viver no comércio e com dois sítios de cana, um com alambique de cachaça ${ }^{51}$. Nós não tinha a casa de farinha, mas tinha o engenho do alambique de Cachaça. Quando era pra fazer 
farinha a gente pagava aluguel nas casas de farinha dos outros particular, pra fazer a farinha pra lá, mas pra a rapadura e a cachaça fazia no engenho lá de casa ${ }^{52}$. Nós tinha um engenho, um alemãozão número cinco e um alambique grande, fazia a cachaça. E vendia a cachaça em grosso ${ }^{53}$, dava muita cachaça! Dá muita cachaça! Tỉnha uns quatro quilômetros de cana ${ }^{54}$ a pessoa tira um tanto pra rapadura e outra pra cachaça. Fazer aquela cana que já é mais assim azulada e aquela que dá a rapadura meio morena. A gente sempre fazia rapadura com a cachaça é mais vendável e eu acho que mais fácil de botar.

Pois bem, agora eu nesse tempo, em 32, eu tava com nove anos, quando eu era menino meu pai botou nós pra aprende na escola ${ }^{55}$, lá com professor velho que sabia muito pouco, com distância de légua e meia, tinha que andar 9 quilômetros, de pés! pra chega lá pra pegar bolo, um carão! Só bastava a pessoa errar uma besteira que pegava dois bolos! Uma carranca mais feia do mundo. E tinha menino fraco que se urinava. Eu acho muita graça quando lembro disso! Era uma bagunça e quando o camarada não dava a lição já viu, colocava ali uma tábua um bocado de caroço de milho e ele ficava de joelho em cima dos caroços de milho até segunda a ordem, só saía de lá quando ele desse ordem pra gente sair! E aí ficava ali aguardando. A gente ia pra escola tudo já apavorado por medo do professor que era muito carrasco. Alguns choravam e aqueles mais fortes agüentava sem chorar $^{56}$. Assim a gente ia estudando a carta de A B C, depois passei pra uma cartilha e me arrumaram uma tabuada também. Meu pai pagava a ele por esse luxo cinco mil réis por mês ${ }^{57}$. Naquele tempo era réis! Ele tinha mais valor do que o real hoje em dia! Naquele tempo era o réis! E o meu pai pagava cinco mil réis por cada um de nós, porque nós era sete irmãos ${ }^{58}$. Nesse tempo eu ainda era o caçula, era o mais novo. E o que é certo é que passei pra cartilha e aí da cartilha foi que nós saímos pra Cascavel. Eu vim terminar os meus estudos já em Cascavel ${ }^{59}$. Fui estudar já o primeiro livro ${ }^{60}$.

Em 1932 nós nos mudamos pra Cascavel e tudo mudou. Porque em Aurora nós tinha gado, tinha cavalo, tinha burro, tinha muito animal! Tinha umas 600 cabeças de gado! Era uma fazenda no sertão! Aurora é o maior sertão do Ceará! De Aurora pra o mar de Fortaleza dá os 800 km, é longe! Eu gostava muito de Aurora, porque a gente nasce num canto, o lugar que a gente quer mais bem é ali. Mas menino não faz o que quer! ${ }^{61}$

Quando o meu pai tirou as passagens de trem pra nós vir pra Cascavel eu estranhei o negócio do trem, tive medo! Aí eu fiquei, e veio a família todinha. Fiquei pro homem vir me trazer em costas de animal pra Cascavel. Nunca tinha andado de trem! Eu via ele passar assim lá longe! No tempo só tinha duas máquinas: tinha a máquina Mariquinha e a “301”. Arrastava 25 carro cada uma! Passava com aquela zuadona feia, medonha! Me assombrei! Com nove anos assim, caboclo do sertão 
é meio bravo. E eu achei que aquilo era um absurdo e eu tive medo! É engraçado contando isso agora! $^{62}$ Aí veio esse homem que lá nós chama arrieiro que trabalhava por patrão, aí veio. Gastemo não sei quantos dias de viagem. Teve lugar no Ceará, travessia que ninguém podia beber água, que a água era puro sal, principalmente lá pras bandas de Iguatú e aquele Icó, é o lugar. Em Iguatú até nem tanto que tinha aquele riozão seco chamado Jaguari, mas do Iguatú pra frente e passando o Icó, aí o camarada sofria! Dava sede ia beber e não podia, a água era mesmo que sal. E deles que tinha água doce mas negava, porque a água era pouco, só dava pro consumo da família. Imagina que passageiro assim, aquilo só ia uma vez, não adianta agrada muito, ele só vai passar ali aquela vez, e negava água pra nós, mas assim nós encontremos também gente boa ${ }^{63}$, até que eu cheguei em Cascavel.

Agora quando eu cheguei em Cascavel aí a vida mudou! Porque lá em Aurora, nós tinha muito leite, a coalhada, o queijo! ${ }^{64}$ É as coisas do sertão! Tudo imperava muito lá em casa, agora rapadura nós comprava particular num lugar chamado Cariri. O pai comprava quatro carga de rapadura botava na dispensa, que é pra manutenção da casa. Isso em Aurora!

Agora em Cascavel, mudou! Nós viemos nove km pra beira do mar! Eram dois sítios grandes de cana, tinha o sítio do córrego e o sítio da bica. Um engenhozão alemão número 05 com três moenda e o alambique de cachaça, casa de engenho e os bois rodando dentro da casa ${ }^{65}$. Agora aquela cana caiana e a manteiga que dá rapadura branca tipo uma canjica, nós tirava pra fazer a rapadura. A cana pitu, a cana rosa, denerária, calvangi e flor de pulba essa a pessoa tirava pra fazer a cachaça, porque ela dá o mesmo álcool, mas sendo pra rapadura a garapa saí meio morena e ela não tem a garapa branca! Aí só ia destilar normalmente: pegava aquela moí, tira aquela garapa, abre um carreira de dorna de quase 2 metros de altura, mas sendo roliço, todo feito de tábua! E enche aquelas dornas tudinho de garapa! Agora bota até lá em cima porque não pode fechar, porque senão ela espoca, estoura! Bem feita com aqueles arco de madeira, aqueles arco medonho. E o que é certo é que com 8 dias é que a garapa pode ser destilada, aí bota dentro do alambique aquela garapa com 8 dias que tá armazenada na dorna que é um barriuzão de madeira serrada. Um bicho daquele pega uns 400 litros de garapa cada um e tinha uma carreira de 16, tudo cheia pra desmanchar com cachaça! E aí é como se diz: é secando um e botando a garapa de novo! Agora aquela que a gente bota só com 8 dias que vai destilar e a primeira cabeçada é álcool que sai! Sai o álcool! Agora a gente ali com o termômetro marcando o grau, naquele tempo era 48 graus o álcool, caindo ali naquela dornazinha pequena, na coretazinha pequena caindo. Quando ela caía dos 48 que ficava nos 40, aí vai descambando pra 22, a gente tirava aquela e botava uma etiqueta na boca dela, que aquela é álcool separado. Botava a outra separada, aí era a cachaça. Aí ela agüenta em 23, 22 graus é cachaça boa todo tempo! Agora quando ela quis cair daí, também para o negócio porque aí não é mais cachaça, começa a ficar xixi, não é mais cachaça, é fraco! Tem que ser destilada novamente com a 
garapa até aproveitar aquele álcool todo que ela tiver! E assim ia lutando e aquela cachaça dava um rendimento grande. Agora a pessoa bota um nome na cachaça e compra o selo e compra o rótulo pra botar nas garrafas e compra as garrafas, faz o engarrafamento e as cortiças, muitos sacos de cortiça pra tampar aquilo tudo! Quem fazia isso era os trabalhador! ${ }^{66}$

O meu pai vivia na bodega, no comércio, para trabalhar na cana tinha os trabalhador. ${ }^{67}$ Eu quando cheguei em Cascavel tinha nove anos, eu tangia os bois no engenho ${ }^{68}$ que tem o moinho gigante do engenho, uma manjarra grande que ficava rodando todo o tempo, uma manjarra com três juntas de boi arrastando, porque o engenho era grande! Era esse alemão número cinco. Cada moenda dá quase uma tonelada! Agora botava uns quatro pedaços de cana, daquela caiana e manteiga, aquela cana boa! Fica pesado pros bois! Duas juntas é pouco pra arrastar. E eu era tangendo os bois, com uma vara com um prego na ponta. Às vezes de malvadeza dava umas cutucadas nele, pra ele ajudar o outro porque tem gente que é escorão e boi também! ${ }^{69}$

E o que é certo é que foi assim até que quando foi em 1936 meu pai morreu com 54 anos. Apareceu uma doença aí! Um camarada chamou ele para andar aí numas terras, pra ir limitando umas terras mais outro, um grande proprietário de canavial, chamado Juarez; e eu sei que quando ele voltou, voltou já se sentido mal. E o doutor melhor que tinha em Fortaleza nesse tempo era o Costa Araújo, ele foi pra lá, bateram a chapa de raio x nele, e veio pra lá, a gente via tudo que ele tinha, agora dizia que ele tinha uma infecçãozinha boba! E eu sei que ele durou uns catorze dias depois que se queixou doente, morreu logo! Com 54 anos, homem forte ainda ${ }^{70}$.

Aí minha mãe ficou viúva, viúva de boa vida! Sempre naquele papel de mulher correta, de respeito e na companhia de oito filhos ${ }^{71}$. Tinha nove, mas uma era casada, a Etelvira, a mais velha já estava fora. Minha mãe teve doze filhos. Morreu três e criou nove. Agora sete são homem e duas era mulher, a Etelvira e Maria. Essa é arriscado tá viva, ela está com 60 e poucos anos, agora a Etelvira não essa já tá bem de idade, essa já sei que morreu. E o que é certo é que ela ficou na luta dos sítios, lutando! Mas a mulher nunca é como homem e aí foi indo pra trás! ${ }^{72}$ Quando dá fé o rapaz se formando rapaz não queria mais ir pro serviço outro pensando em casar, outros cantos pra sair e com pouco tempo o negócio foi fracassando ${ }^{73}$. Mas meu pai antes de morrer tinha comprado uma casa particular porque esse negócio do sítio era sociedade. E o negócio foi fracassando e os filhos saindo. Começou a vender a cana pra uma usina em Cascavel muito grande! Do Francisco Augusto de Deus. Não tava mais fazendo rapadura, nem mel, nem cachaça e saímos de lá e fomos pra essa casa que o meu pai comprou quando era vivo. Aí fiquemos lá nessa vida, fiquemos só com o sítio da bica mas não se fazia nada, só cultivar a cana. Muita plantação, muita fruta! Muita bananeira dando fruto e cajueiro muito! Coqueiro tinha demais! Tinha umas duzentas árvores de coqueiro e tudo 
carregava bem! Agora vivíamos só daquilo. A cana era cortada e vendida a carga a cinco mil réis naquele tempo. Era vendida pra usina: o camarada mandava cortar, pagava o cortador e se a pessoa quisesse que nós carregasse tinha uma tropa de trinta burro. Ainda houve uns lá dos meus irmãos que carregaram uns vinte e eles pagavam, assim mil e quinhentos por cada carro ao todo pagava o frete. E assim foi indo, foi indo até que chegou um tempo que eu também me casei e foi quando veio esse desmantelo da guerra de $39^{74}$.

Quando conheci minha mulher eu estudava num colégio chamado Rio Branco colégio particular e ela estudava no Grupo ${ }^{75}$. Naquele tempo o Getúlio Vargas tinha liderado aí um negócio das professoras quintanista, naquele tempo ela fazia o quinto ano, que depois que tirava o diploma do quinto aí podia lecionar. E a gente sempre se via perto dali. Desse jeito atraiu amizade e a mãe dela também, que ela não tinha pai só tinha mãe ${ }^{76}$. A mãe dela mesmo foi quem se interessou de casar a filha dela comigo. Eu também não era má pessoa, também não vivia muito mau. Tava empregado nesse tempo numa loja de um homem chamado Vinício. Ganhava pouco! Noventa mil réis por mês, isso pra mim é pouco!

E o que é certo é que nessa vida boa que eu tava com seis meses de casado a minha mulher já tava grávida e lá vem essa guerra de 39, então eu fui convocado ${ }^{77}$. E nunca mais encontrei com ela. Quando tinha condição de voltar pra lá que escrevi pra lá a mulher tinha morrido. Morreu a mulher e a criança, tinha nascido uma criança, morreram naquele ano mesmo. Chamava-se Maria Estela Pereira, antes de casar comigo Maria Estela Barros, mas quando casou ficou assim. Então eu nunca mais voltei, no ano que a gente chega assim novato não tem como voltar, é muito longe! A gente tem que ganhar primeiro, tirar saldo do patrão pra fazer aquele dinheiro pra poder voltar e eu só pude conseguir isso com dois anos de serviço. Porque o primeiro ano o sujeito compra tigela de seringa, compra faca pra cortar seringa, compra um machado, compra fazenda pra fazer o saco. Aí vai abrir a colocação. Tudo caro! Naquele primeiro ano quando o sujeito é feliz e tem espírito de trabalhar, tem coragem de trabalhar ainda paga a contas. Agora no outro é que ele vai trabalhar pra ele! ${ }^{78}$

E foi o que aconteceu comigo, quando foi com dois anos que eu tinha condições de voltar, escrevi pra lá e já veio essa notícia que minha mulher tinha morrido! Eu digo: "bem, agora a vaca foi pro brejo!" Não tenho mais nada a fazer, vou ficar por aqui mesmo! Porque eu não tinha porque voltar, casado ainda ia, podia adquirir alguma coisa, porque era casado no católico e civil, mas eu imaginei que quando chegasse lá não arrumava nada e assim eu me agüentei por aqui. ${ }^{79}$

Quando fui vendo a Amazônia, porque eu não vinha do sertão, eu já vinha de dentro da praia de Cascavel, não é dentro do sertão! Mas nasci no sertão! Vinha da praia, da beira da praia e eu 
vim achando assim uma coisa muito diferente da nossa terra, umas árvores muito monstruosa! Muito grande! E um sistema todo diferente ${ }^{80}$.A gente vem estranhando, porque na nossa terra a gente vê o vaqueiro passar na porta da gente tocaiando uma manada de gado, depois vem o boiadeiro naquela vida mais animada! E cantador repentista, aquele violeiro chamavam e tudo aquilo alegra muito! E pra cá o camarada passou do Maranhão não se vê mais essas coisas de jeito nenhum e só se vê água e mata selvagem medonha! E quando chega aqui no seringal é doença, é carapanã, pium, borrachudo e cobra tem em tudo quanto é canto. E tudo é só pra acabrunhar a pessoa que vem pra cá! E quando o sujeito atravessa, na idade que eu tô, mesmo alejado, com setenta e cinco anos que vou fazer agora no dia 19 de abril, ainda é aqueles feliz! Mas Muitos se acabaram aqui mesmo! Só o clima do lugar é muito diferente do nosso. As chuvas aqui tá mais pouca, tá parcelada, mas quando nós chegamos aqui chovia quase todo dia, chovia demais aqui no norte! E para quem nasce no sertão que quando dá uma chuva pra gente é uma novidade, chegar num lugar desse, aí a pessoa vai estranhando muito! Chega a ser engraçado! Quando chega no seringal aí é que a pessoa estranha! ${ }^{81}$ Porque sempre no Ceará, apesar da má reputação do Estado, mas o Ceará é um estado bom, Eu gosto muito da minha terra! Lá a gente sabe que tem uma vida muito sofrida, vem pra cá que é um lugar que ainda ta tudo avulso, e quem quer um pedaço de terra vem pra cá, porque lá não tinha mais condições pra isso, mas lá não é ruim não! ${ }^{82} \mathrm{E}$ o que é certo é que lá quando agente tem um patrão na chegada conhece quem é o patrão ali no meio dos trabalhadores e aqui se misturam um com o outro, e às vezes o patrão é mais a toa do que os trabalhador, principalmente no seringal. Eu trabalhei com um moreno lá no seringal só tinha muito era dinheiro, sem presença de tudo, era um cabra assim medonho! E assim a gente estranha tudo porque no nordeste o patrão é sempre o homem mais vistoso quem tem por ali, o mais bem trajado. Pra cá a pessoa ignora andar limpo! O patrão do seringal, um homem que dava mais 400, 500 tonelada de borracha andava com o pé no chão, roupa de mescla com um remendo aqui e outro acolá! Eu acho é graça nisso! Mas isso eu recebia com muita estranheza! Porque lá pra nós não existia isso não, lá o patrão sempre se distinguia do trabalhador, mas aqui é assim e isso tudo a gente estranha um pouco! ${ }^{83}$

Agora os seringais são bonitos! O primeiro seringal que eu fui era o Seringal São Domingos. Lá a vida era só extração da borracha! A pessoa ia pra colocação pra produzir a borracha. Aviado por mês! Tinha o noteiro que vai na casa da gente fazia aquela nota, o que o sujeito precisa bota naquela nota, aí quando chega no fim do mês o patrão manda as mercadoria que agente botou na nota, pelas costa de burro e deixa lá na casa da gente. Mas se o sujeito tiver condição, se não tiver a mercadoria volta! E aí todo mês naquela vida, todo mês.

Quando chega o verão que a seringa fica ruim, da pouco leite a gente vamos quebrar castanha. No verão a gente trabalha numa empreita, de janeiro até meio de março a gente quebra 
castanha. Agora a castanha a gente tem que lavar dentro d'água num pandeiro grande, pra tirar toda a castanha avariada, que não tá boa! Faz um paiol e deixa lá, o patrão manda buscar em tropa de burro. Quando não tem caminho a gente abre, o camarada que quebrou a castanha abre o picadão. Aí nós vai até lá e pega aquela castanha e o patrão paga a conta. Agora quando chega assim o mês de abril o camarada vai pra estrada cortar a seringa e passar o terçado pra tirar aquele serrado do meio, aí vai até dezembro, corta até dezembro! Se ele tiver um saldo ele baixa pra Manaus pra receber. Gastava-se um mês de viagem mais ou menos, do Seringal para Manaus, até Lábrea. Porque o sujeito vem tem de pegar aquele motor de 100 pequeno, mas pega um motor descendo daqui, tem aquele batelãozão que carrega até 400 pessoas, mas tem canto que tem cachoeira e é uma atrás da outra! Aí a pessoa desse do barco e anda por terra e vai pegar um carro na frente, pra depois em baixo pegar uma lancha, até que chega na Lábrea e de lá é que o sujeito pega um navio da linha. Naqueles anos tinha o Tupi, o Distrito Federal, o Belo Horizonte, o Benjamim e outros mais! Tudo navio de convés baixo, navio de rio que chamava de gaiola! Aí é que a gente ia chegar em Manaus. E lá ele pagava o saldo corretamente, e aqueles que eram vaidosos estouravam o dinheiro todo, não fazia futuro e voltava pra trás com o mesmo patrão e assim quando iam se dar conta que a vaca tinha ido para o brejo, já estavam com muita idade e com muitos anos que trabalhava, não tinha futuro nenhum! Muitos fazia isso! Mas tinha muitos que fazia uma economia e baixava pra terra deles e melhorava a condição de vida.

Mas eu nunca quis ir pra minha terra. Primeiro que eu deixei isso pra trás que lá em casa ainda é do tempo do carracismo, um irmãos mais velho castigava os mais novos e aí tem a desunião. Mais novo do que eu só tem dois, tem a Maria e tem o João, eu sou mais velho do que a Maria catorze anos e do que o João, cinco. Eu fui caçula por cinco anos. Mas mais velho do que eu tinha o Pereira, tinha o Sebastião, tinha o Paulo, tinha o Adércio, o José que chamava Zezinho e a Etelvira. Agora esses todos por qualquer besteira me pegava pela munheca e dizia: "hoje você vai pagar o novo e velho". Sem eu ter nada que ver, por causa de uma besteira. Quer dizer que aí o camarada vai perdendo o amor pela família e foi o que aconteceu comigo. Por isso que não fiz sacrifício de voltar mais pra lá, não me dava com nenhum! E eu achei que eu vivendo assim fora era melhor, que também a gente ser da família e viver desunida não adianta, porque aí não dá pra se amar de jeito nenhum, brigando feito uns cachorro, uns pra lá e outros pra cá, eu achei que eu tava melhor!

No Começo quando cheguei no seringal eu achei assombroso!Uma mata terrível, árvores medonhas! Tem árvores aqui que só uma tal de Sapopemba que elas no pé dá uma tábua maior do que um guarda-roupa de 2 metros! E isso aí eu não via no Ceará porque a nossa mata lá é fina. Lá tem o Angico, o Monjolo, Aroeira, Baraúna, Catingueira, Munsalá, Pau Amarelo, Perero! É assim, mas tudo é árvore pequena que um ou dois homem abarca. A árvore maior que tem lá é uma que chamam de Timbaúba, mas é uma árvore maneira. ${ }^{84}$ 
Quando eu vi que ia trabalhar dentro de uma floresta dessa eu me vi apavorado! Porque eu me achava um homem, só, novato entrar numa mata selvagem assim, escutando esturro de onça medonho! E o camarada sem uma arma de fogo boa, sem nada pra levar! Só uma faquinha do lado. Tinha uma espingarda mas eu não me dou com arma pra levar pro serviço, acho que perturba muito e dá trabalho. Eu só levava uma peixeira! Mas quando eu ouvia o esturro da onça me arrepiava todo! E eu digo: talvez hoje é o dia que ela vai me comer! Tinha aquele trauma, aquele medo! Mas nunca elas se botaram a mim não!

Eu via muito onça e matei muito! Matei Canguçu, matei Maçaroca e até Suçuarana, uma vez veio vindo uma meia amarela e eu matei! Agora o Canguçuzão, aquele pintadão, eu matei direto, eu matei até aquela acuada com cachorro. O cachorro faz a cabocla subir, o caba chega já tá de cócora no zóio do pau, passou um dezesseis assim na goela e ela embola e joga pra lá! E a gente fica meio apavorado quando vê essas coisa. ${ }^{85}$

Já as coisas tudo lá pra nós tem uma alvorada de pássaros bonito de madrugada! Tem a alvorada de abelha, é uma lindeza aquela coisa! Aqui a gente vê a coruja dá um berro que o sujeito nem sabe o que é, imagina logo que é esse tal de Mapinguari! As vezes não tem uma pessoa que diga a gente o que é! E a agente fica com aquilo no juízo! Eu acho muita graça disso!

Dizem que o Mapinguari é um bicho que tem na mata, mas eu nunca vi. É um bicho doido, grande, selvagem! Tem o corpo de um homem, mas que bala não entra nele. E contavam isso e isso faz mais medo no pobre do seringueiro. Aí eu ouvia as corujas cantar, cada um canto mais feio do mundo! Grito mais feio do mundo! Aí eu disse: isso aí deve ser esse bicho! Eu não sabia que coruja daqui canta feio e dá um medo no mato. O camarada só sabe o que é hoje em dia, mas no meu tempo não sabia não. A gente chega novato, eles chamam bravo, ninguém sabia o que era aquilo! Eu só pensava que ia encontrar com esse bichos doido! ${ }^{86}$

E o que é certo é que eu sempre no outro dia eu ia mais com muito medo! Aquele nervoso medonho e andando ligeiro pra acabar cedo com medo de ficar de noite na mata, porque ficar de noite é um perigo! Aí ela pega! Mas esse tal de Mapinguari isso é conto do povo! Não tem não, mas o novato fica com medo e acredita, mas não tem. E ainda tem uma serpente muito medonha chamada Bico-de-Jaca! Ela também dá um nervoso na pessoa, tem uma picada horrenda muito venenosa! Tem muitos aí que diz que já viu gente escapar dela. Agora de catorze que eu vi ela morder nunca escapou, não passa das 12 horas, ela botou a boca é a morte! Não avisa a hora. É o Bico-de-Jaca! E isso tudo metia medo na gente! Mas eu tinha mais medo desse bicho alarmento! O Jacú riscava a árvore e um tal de Cujubim também, um pássaro bonito! Tem uma zoada assim rom, rom, rom, rom, rom que ninguém sabe de onde vem, que vem sempre lá das árvores, o camarada olha e não vê, é de madrugada, o camarada diz: “o diabo tá solto aí!” O Bicho faz um roncado 
doido! Aí a pessoa fica aperreada, não sabe o que fazer e é logo pro lado da estrada, no rumo que a pessoa tem que ir naquele dia.

Tinha também uma história que contavam, que tinha a Cobra Grande, uns quatro metros, uma Sucuri! Nesse lugar que eu tava morando antes de vir pra cá eu matei uma delas de catorze metros. Eu tinha um cachorro grande misturado com pastor, eu sempre gostei de criar um animal assim. É bom a gente possuir o cachorro que é amigo do homem! E eu tinha o meu cachorro e ele foi pro mato já na beira desse rio que era costume dele se deitar debaixo das mangueiras, das árvores que é muito frio. E eu chamei, chamei, cacei e nada. Fui pra beira do rio e tinha uma sulapa grande, com a alagação que ele deu, fez uma rachadura grande e eu vi lá dentro da rachadura aquele bichão preto! Essa desgraça foi quem comeu o meu cachorro. Aí eu fui em casa peguei uma 16, cheguei e atirei nela no lado, perto da cabeça pra quebrar o espinhaço! Era ela mesmo! Ela saiu de dentro da sulapa e entrou feito doida quebrando cana brava que tem na beira do Madeira, até que se aquietou e eu fui olhar. Matei ela de manhã. Quando foi duas horas da tarde que eu tive coragem de medir, porque eu já sabia que ela tinha morrido mesmo! Eu estiquei ela e medi catorze metros, mas se a pele tivesse sido bem esticada é capaz de dar mais. Era um animal monstro, que o cachorro era grande! Era um cachorrão! Era da grossura daqueles tambor de gasolina de vinte litro, essa era mais ou menos a grossura dela, no lugar mais grosso, no meio e, principalmente, onde tava o cachorro! Pro lado do pescoço era mais fino. Ela pega e engole o bicho inteirinho, engole inteirinho! Ela pega com a boca, o bicho só dá um grito. Aí ela dá um laço envolta do bicho e solta a boca e o bicho cabe dentro daquela boca. Ela esbagaça o bicho todo por dentro, quebra a costela, racha o fígado, o bofe, e ela só faz engolir. Ela faz com cachorro e faz com a pessoa.

Agora o Boto onde eu trabalhava tinha pouco, tinha mais na Lábrea, tem um boto assim meio azul, tem um boto pequeno, preto chamado Tucuxi e tem o vermelhão, que chama Boto Vermelho, esse é um enorme! É um enorme esse vermelhão! São três espécie de boto. Contavam que aquilo era um encanto, mas que eu quase não acredito. Diz que ele se vira em gente para fazer tanta besteira, andava nas festas, adispôis caía na água de novo. Mas isso eu não dou crença, não! Mas boto aí no Purus tem demais! Tem um vermelhão, diz que ele não come gente, mas ele se bota debaixo das canoas e balança, assim que se a canoa vir carregada, ele alaga! Ele é um bicho grande com mais de 4 metros esse vermelho, agora os outros são menores.

Quando eu vi o rio Amazonas, o rio Madeira eu achei que dentro de uma água dessa é capaz de ter tudo que o povo inventa de ter, porque é água demais, é água demais! A pessoa se vê perdida no meio de tanta água. Quando a gente vem de Belém tem aquela baía do Rio Negro, que tucano não atravessa aquilo, a água é preta! Eu cheguei eu digo: “Ave Maria, isso aqui é um absurdo!, Que diabo é isso?!” Até que graças a Deus saiu de lá e cheguemos em Manaus, mas eu tava meio nervoso 
com tanta água, tanta água! A gente vê mato de um lado e do outro, mas se vê longe o horizonte assim fica um bocado puxado, Tucano não atravessa! Tucano meter a cara caí n'água, não atravessa ali não! E eu achei que era uma terra brejada de tanta água, e todas as histórias que o povo conta aí eu digo: "é capaz que seja verdade mesmo". ${ }^{87}$

Quando eu fiquei doente, senti uma dormência nas pernas e as pernas ficou assim meia mole. Agora que eu não tinha mancha no corpo, eu não tinha nada! Agora as pernas ficou assim meio bamba. Aí com pouco dias não queria nem mais andar, fiquei ruim das pernas, isso foi uns dois anos de eu vim pra cá que eu senti! Aí que eu vi que podia ser uma doença ruim! Eu vim pra cá para comunidade Santa Marcelina no dia cinco de 1978. Cheguei aqui eu tive com um médico, que tratava aqui com dermatologia, o doutor Francisco Jadir, um paraense. Eu fiquei aqui nove meses, no dia nove de janeiro de 1979 eu saí daqui e fui pra casa. Isso da primeira vez!

Eu pensava que fosse esse mal mesmo, a lepra, porque dizia que atacava as pernas e dava dormência e eu estava com essa dormência nas pernas mesmo, eu tava ficando mesmo pra não andar, já estava andando com dificuldade. Aí eu vim pra não deixar pra cair! Quando cheguei no Osvaldo Cruz, um hospital que tinha nesse tempo era um mais velho, um que tinha na beira do Madeira. Lá apertaram minha orelha, apertaram o joelho e o cotovelo, era só pra tirar uma água de dentro da pele, não era pra tirar sangue, só uma água! E me mandaram para o Hospital daqui. Quando eu soube o que tinha eu me achei perdido, bombardeado! Isso foi em 78, minha doença é dessa época. Eu achei que contraindo uma doença dessa, eu não sou mais homem pra nada! Porque do jeito que contavam o homem era destruído! Contavam que ía cai os braços, caí as pernas, e caí orelha, e caí beiço e cai tudo! Cada vez a pessoa ficava mais apavorada. ${ }^{88}$ Mas depois fiquei sabendo que com esse remédio não é mais assim. Quando chequei o médico me deu uma injeção muito boa. O médico se chamava Jadir, ele me dava 1cc por mês, diz que era muito forte, agora 1cc no mês, 2cc no outro, $3 \mathrm{cc}$ no outro, e assim ia graduando até que chegou o mês de eu receber uma toda, de $5 \mathrm{cc}$. Aí quando foi com nove meses que eu tava aqui, que eu saía dia nove de janeiro, fui a rodoviária de Porto Velho. O doutor Jadir disse que eu já podia ir pra qualquer canto mundo que tinha mais nada não. Estava Bom!

Nesses nove meses que eu passei aqui era muito bom, era muito bom! A gente chegava aqui jogava até futebol, eu joguei aqui! Tinha um supermercado com muita mercadoria e eles tratavam muito bem as pessoa e o remédio era constante. Toda quinta feira Irmã Rosa, que era a chefe, ela tá 23 anos de serviço aqui nessa comunidade, pegava uma Kombi, e mandava nós para Porto Velho. A Kombi levava e trazia. Nós íamos comprar alguma besteirinha, tudo era aposentado recebia aquela mixaria, ela pagava aqui mesmo, ninguém tirava no banco, ela quem tirava. Aqui nós tinha um cardápio, também, muito bom, assistência e muita visita. ${ }^{89} \mathrm{O}$ que eu tô estranhando é que hoje as 
visitas são poucas! Naquele tempo do Governo militar do Presidente Figueiredo havia muita visita do Rio de Janeiro, vinha visita de São Paulo, vinha do Nordeste, vinha de todo o canto! Esse hospital se enchia de gente visitando! E vinha gente de todo lado mesmo pra visitar as pessoas. Vinha estrangeiro desse povo japonês, Italiano, vinha padre conversar com a gente! Faziam muita visita e animavam muito as pessoas daqui tirando o medo da pessoa que não fica na situação daqueles antigos! Eu acho que hoje em dia já tá mais diferente é difícil aparecer uma visita, quando vem é um conhecido. Meu medo era de ficar inutilizado sem poder trabalhar e caindo os dedos, e caindo um pedaço de um dedo, diziam que caia. Caía, mas já tinha passado esse tempo, agora não tava mais caindo não. ${ }^{90}$

Eu sonhava aqui, tinha pesadelo! Numa ocasião tive um pesadelo com uma fera que ficava atrás de me pegar! Eu queria falar e não podia, a língua pesada! A pessoa quer gritar por um conhecido, uma pessoa que tá ali e não tem como gritar! A língua não deixa! Isso me aconteceu muitas vezes. ${ }^{91}$ Teve uma ocasião que eu caí até da cama. A minha cama era alta e eu estava no hospital quando eu caí dela com um pesadelo. E o que é certo é que assim fui atravessando depois de nove meses fui embora, voltei pra minha casa lá no terreno. ${ }^{92}$

Eu tinha uma companheira, morei com ela 30 anos! Quando conheci ela eu já estava aqui na Amazônia nesse tempo eu era sadio! Foi no seringal, numa festa de seringal, que em seringal tem muita festa! Começamos a namorar, a ter um xodó, mas eu fico muito envergonhado e acho muita graça contando essas coisas! ${ }^{93}$ E o que é certo é que ela foi morar mais eu, que eu tinha condições de possuir uma mulher, que eu tinha minha colocação, tinha tudo! ${ }^{94}$ Isso foi depois de 1954 , nesse ano morreu Getúlio Vargas ${ }^{95}$, em novembro, mas nesse tempo ela vivia com um companheiro, mas depois se deixaram! E eu não me lembro ao certo o ano, mas foi depois, aí eu me juntei mais ela e levei para casa e fui trabalhar mais folgado! Porque o camarada com família não é como solteiro que chega tem que fazer tudo! Bater roupa, lavar roupa e fica pesado pra pessoa e tendo uma mulher ela é que fazia tudo! ${ }^{96}$ E o que é certo é que eu achei uma melhora na vida! Ela não constituiu família de jeito nenhum, não tinha filho de jeito nenhum! $!^{97}$ Quando foi no dia 15 de julho de 1960 uma vizinha minha deu a luz a uma criança, era um menino! Ela não tinha condição de criar, eram muito pobre! Aí disse que como nós era um casal de gente assim direita, que tinha uma colocaçãozinha e se quisesse o menino ela dava. Eu disse: "hora, mas isso eu aceito de bom gosto que criar uma coisa dessas é uma dos melhores acontecimentos que já se deu na minha vida! Ser pai de uma criança é coisa de muito orgulho!” Aceitei de bom gosto e fiquei com o menino. ${ }^{\mathbf{9 8}}$

Quando ele estava com quinze anos, justamente no tempo que eu vim pra cá, pra comunidade, ele ficou só com a mãe dele em casa. Um camarada atirou numa capivara lá no Madeira 
e chamou o rapazinho pra ir vê se encontrava a capivara no Madeira, numa canoa veia furada, o rapaz não sabia nadar e morreu afogado. E eu recebi essa notícia aqui com muita tristeza porque era a coisa que eu queria mais bem no mundo era meu filho! Porque não era meu legítimo, mas no dia que nasceu, foi cortado o umbigo dele lá em casa! Era como se fosse. E aí eu fiquei arruinado! ${ }^{99} \mathrm{E}$ o que é certo é que ficou só eu e ela. Quando foi no dia 12 de junho de 1996 minha companheira foi sepultada, ela já tinha 79 anos, ela é do dia seis de março de 1917, era mais velha do que eu seis anos, morreu aqui nesse hospital do João Paulo II de uma tal infecção respiratória, eu estava lá com ela.

Eu cheguei, de volta, no dia 19 de março de 1997, às 8 horas da manhã, vim numa ambulância com um militar e a $\operatorname{Dr}^{a}$ Kasuir e quando foi umas cinco e meia da tarde a irmã Bernadeti, sem eu saber, me levou para o hospital e o cabra cortou minha perna! Cortaram sem me dizer! Já faz um ano, no dia 19 de março de 1998 faz um ano. É triste! Cortaram minha perna e eu fiquei aleijado. E agora fiquei aqui com um ordenadinho de cento e vinte reais e não tenho condição de sair daqui ${ }^{\mathbf{1 0 0}}$, por que não dá. Já tentei vender meu lugarzinho, quando tava bom cansei de recusar oito mil reais, mas não queria vender que sempre gostei das plantação. Esse lugar é longe, $226 \mathrm{~km}$ daqui perto da balsa que atravessa pro Acre. E o que é certo é que eu já mandei dizer que eu dava por cinco mil reais.

Não saio daqui porque eu não tenho condição de sair. Quando eu vinha buscar meu dinheiro, pagava aquele motel com banheiro perto da rodoviária, a oito reais. Agora a pessoa ganhando cento e vinte reais, pagando durante dez dias dava oitenta e quando for pagar vinte dias dá cento e sessenta, como é que dá? Não dá de jeito nenhum, por isso eu estou por aqui. ${ }^{101}$

Mas também as irmãs são muito boas! Um tempo desse eu tive aqui um pouco enfezado, agoniado demais. Ave Maria! Elas me disseram para eu me comportar bem, agüentar um ano para poder sair e isso aí me animou muito porque com esse ordenado não dá! Com cento e vinte não dá para o camarada se deslocar daqui de jeito nenhum, vai só sofrer! E eu me comporto mesmo, eu estou velho mesmo! E também um homem de setenta e cinco anos não pode ficar dando murro em ponta de faca e assim eu vou agüentando por aqui. Mas que de todo jeito a pessoa que toda a vida foi liberta acostumada no que é dele vendo fartura disso e daquilo, sempre dá aquela vontade de sair, mas o negócio é que não há condição pra isso! Não tem condição pra sair! ${ }^{\mathbf{1 0 2}}$

E esses outros internos, tem deles aí que tá como eu e outros pior em situação mais ruim e por aqui tem pouco os que tem condição de sair, e os que não tem, acabam vivendo aqui mesmo e aí as irmãs tem que usar de clemência pra não expulsar, porque se botar para fora vão sofrer, passar fome, passar necessidade. Todos aqui só recebem um salário da aposentadoria. ${ }^{103}$ 
Agora eu um homem aleijado de uma perna, o que quê ele faz? Não faz nada! Aqui já tenho uma perna prometida que chamam prótese para botar no lugar! Tiraram a medida um dia desse e agora tem que me chamar pra experimentar, mas ainda não chamaram não e eu estou aguardando. A barra é pesada. ${ }^{104}$ 


\section{A ESCOLA}

\section{"E na carta de $A B C$ que eu tava estudando \\ tinha escrito que "quem não ouve conselho rara vez acerta" e era mesmo se você num ligou, num prestou atenção entra na peia. E entrava mesmo!”}

Em 1928 eu fui para uma escola, já era um pouco atrasado em Cascavel, mas também no sertão de Aurora onde eu vivi não era muito adiantado também. E lá o meu professor chamava-se José Joaquim. Fui na capa de $\mathrm{ABC}$ e aprendi, que tava escrito na capa de $\mathrm{ABC}$ : “A preguiça é a chave da pobreza, quem não ouve conselho rara vez acerta, sem religião e sem justiça não há liberdade e o amor de Deus é o princípio da sabedoria". Tava escrito! ${ }^{105}$

Eu ia dá a lição na regra do Abc. Só no A -B- C a gente ficou três mês e eu ainda batia cabeça pra acertar isso, não achava dúvida! E lá o professor era rigoroso, castigava o aluno se errasse. Não era preciso ser malcriado, era só errar na leitura e já apanhava, pum! E o que é certo é que a gente se intimidava mais com isso, mas assim mesmo eu fui indo e fui atravessando. Saí do Bêá-bá, passei pra outro número da capa, antes disso ele botou eu pra conhecer as letras com um papelzinho furado e ele botando aquelas letras de cabeça pra baixo e muitas vezes eu batendo cabeça pra conhecer um A minúsculo porque de cabeça pra baixo ficava difícil pra mim, mas aí eu conhecia que ele tinha virado a carta e dizia: isso aí é um A. adivinhava, mas não tinha muita consciência que era um A.

Dali eu dei a capa de $\mathrm{ABC}$, aí passei pra uma cartilha, primeira cartilha com esse mesmo professor. Agora daí não era mais esse professor. Meu pai se mudou pra Cascavel, pertinho de Fortaleza, daí não era mais José Joaquim o meu professor, aí eu fui estudar com uma mulher chamada Maria Ernestina, aí já peguei aquela segunda cartilha, a Proença era o nome da cartilha. Aí assim eu fui desenvolvendo o estudo sempre um pouco inteligente, dava a minha lição e botava pra eu ler, era o rascunho. Adepois me botaram com os translado que era pra transladar de lá, ver a letra e botar aqui no papel pra mim. Chamava translado, aí depois dos translado aí já era o ditado, o professor ditava lá da mesa e eu escrevendo aqui, mas que ele não explicava onde tinha um ponto e nem uma vírgula, isso ficava a critério do aluno e se na hora que ele fosse olhar, a escrita tivesse relaxada, aquela escrita, porque onde precisava de um ponto o camarada não botou e aonde precisava uma vírgula ele também não. Aí o sujeito tirava uma escrita assim, mais ou menos, grau baixo, porque o grau melhor naquele tempo era o doze, aí eu assim fui, passei no livro Coração de Criança no primeiro, passei pro segundo livro, aí passei pra aquele que era de leitura, o terceiro, que tinha uma poesia que eu gostava muito dela, de Casimiro de Abreu ${ }^{106}$ : 
"Ai que saudades que eu tenho

Da aurora da minha vida

Da minha infância querida

Que os anos não traz mais

De amores, de sonho, de flores

Naquela tarde fagueira

$\mathrm{Na}$ sombra das bananeiras

Debaixo dos laranjais

Como são belos os dias

Do despontar das estrelas

Respira a alma inocência

Como o perfume das flores

O mar é o lago sereno

O céu um manto azulado

O mundo é o sonho dourado

E a vida é um ninho de amor"

Eu achei esses versos nesse terceiro livro e aí foi aprofundando os estudos e já comecei na gramática, conjugando o verbo e alguma coisa a mais que tinha. E sempre eu dava mão nas lição onde eu já sabia! Naquele tempo havia as análises, agora disso pra analisar hoje em dia só analisa a letra A que é um artigo indefinido do feminino do singular, só isso! Mas o resto não lembro!

Agora os professores passava raiz quadrada, dobrada e extrair um termo de fração, máximo comum, mínimo comum e tudo isso era muito aprofundado e até que eu ia bem assim! Naquele tempo fazia o quinto, mas eu não passei nem no quarto, eu não fiz o quarto, eu só fiquei no terceiro ano! Mas eu estudei aquele outro livro de leitura "Ciências físicas naturais" e ele dá uma lição, era por trecho ou capítulo da história, se pegasse duas páginas ou três tinha que ler tudo, se pegasse cinco folha aí tinha que ser tudo. Agora, o aluno sentado lá na cadeira, e o professor corrigia lá com o livro lá na mesa dele.

E assim eu estudei, saí do estudo com 17 anos, mas eu fiz o terceiro ano secundário que mudaram, naquele tempo era formação de pessoal, hoje em dia é magistério e eu acho que até que aquele estudo era mais severo do que esse hoje! Dava mais compreensão porque tinha muita explicação, na área da aritmética tava escrito que a aritmética é uma ciência elementar de números, 
de calcular por meio de algarismos! E assim eu estudei e sai com 17 anos sai com o terceiro ano secundário e sempre nas minha escritas eu tirava um grau 12.

Eu deixei de estudar, por minha conta mesmo eu comprei o secretário moderno, era rapaz novo, comprei aquele secretário dos amantes pra aprender assuntos delicados, pra escrever pra um namorada, uma moça que a gente simpatizava mas tinha pouco conhecimento com ela, e por meio de uma carta meio assim era capaz de a gente conseguir algo ${ }^{107}$. E por isso era o nome secretário dos amantes! Agora o secretário moderno ensinava a dizer um discurso, ensinava até acertar um casamento civil por ele com ordem do Juiz, e ensinava pra ser um escrivão também. Tudo isso explicava no secretário moderno! E daí deixei de estudar. Comecei a estudar com e deixei de estudar com 17! Eu estudei pouco tempo! Aonde eu aproveitei mais foi no colégio Rio Branco, tinha um professor muito bom, foi com quem fiquei mais desenvolvido! Com esse professor, Hamilton Bezerra! Gostava muito dele, ele era muito elevado, ele ensinava! Lá na sala tinha datilografia, ensinava francês e inglês, aquele inglês americano também, que já tem uma diferençazinha do Português pra nós. Era competente, agora por meio lá de uma inveja ou outra coisa, tiraram ele de Cascavel, pensando que iam fazer mal a ele. Ele foi pra Fortaleza tava dando duas lição no ginásio São João e naquele outro ginásio que não lembro o nome lá em Fortaleza. Aí ficou melhor pra ele e aí era por conta própria dele, a gente que pagava ele, pagava uma importância naquele tempo de oito mil réis o que corresponde oito real hoje em dia! Cinco mil réis tinha um valor danado! O réis era mais valorizado, porque o réis não tinha feio nem bonito pra ele, o dinheiro era que era que tinha valor, e hoje em dia o real não! Vale pra umas coisas e outras não! Isso aí é que eu acho uma falha nesse dinheiro nosso, umas coisas tem valor demais e pra outras não tem de nada, porque pra pagar os homens tudo o real não tem valor! Um dia desses eu ouvi falar que tem um secretário de Porto Velho que tá ganhando sessenta mil real, quer dizer que isso é uma moeda fraca, porque sessenta mil se fosse sessenta mil contos de réis naquele tempo no Ceará era um absurdo! Dava pra comprar um mundo de coisas! Eu acho esses ganhos muito exagerado e um vereador nas épocas de 1958 que eu votei ali no meu patrão que era um homem rico que levou nós tudo pra votar pra ele. Elegemos ele, lá na cidade ele ganha dois mil cruzeiros, já era uma moeda já fraca e o prefeito municipal ganhava do doze mil cruzeiros. Agora o real que no negócio da URV vale dois mil e setecentos e cinqüenta cruzeiros, é um absurdo, isso vale um real! É um cambio muito medonho e um camarada que ganha sessenta mil real se multiplicar por isso pra onde que não vai? Não tem que chegue no fim, dinheiro demais! Eu acho demais!

Quem botou as economias no banco não tem mais nada, não tem valor! Até certo tempo um camarada comprava uma novilha de vaca pro sessenta real, oitenta era uma vaca de um ano. Aí abaixo as coisas no campo, uma saca de milho vende aí por até quatro real, no máximo oito real e 
nada mais! Uma saca de farinha com quinze real, não dá de sitiante mais se fazer de jeito nenhum, ele tem que vir pra rua caçar o emprego porque relaxou o campo. Eu mesmo tinha aí um lugarzinho vendia uma dúzia de limão lá de casa do sítio, quando muito por um real, hoje em dia o camarada chega lá e quer um saco por cinco real, um saco desses grandes!É um absurdo, quer dizer que não tem valor pro campo! É assim, o real, ele é simpático pra umas coisas e pra outras não!

No tempo que eu nasci o nosso dinheiro era o réis. No começo do mundo a primeira moeda nossa foi o cobre, adepois foi substituída pelo réis, e ele perdurou até 1943 quando Getúlio Vargas mudou pro cruzeiro dizendo ele que o cruzeiro ia ficar o mesmo valor! Ensinava ele e mais aqueles homens dando discurso, ensinando que a gente podia dizer assim que um conto de réis pode se chamar mil cruzeiro, tudo é uma coisa só! E assim foi mudando! O Cruzeiro não agüentou dois anos, diz que foi feito sem lastro, porque o dinheiro quando tem uma moeda forte, então o sujeito manda levantar aquele dinheiro bota em ouro pra garantir aquele dinheiro, mas diz que o cruzeiro foi só de boca! Então por isso que não tem valor e aí virou e mexeu aí aquele o Marechal Ernesto Geisel botou o cruzeiro forte, bem ficou bom, ficou bom! Mas não perdurou uns seis mês e caiu.

Passou-se o tempo, aqueles negócio todo, ditadura, até que nas eleições de 1984, morreu um presidente, Tancredo Neves, aquele que foi quem tirou a rédea do país da mão do presidente Figueiredo. Tancredo Neves foi eleito, mas não teve jeito pra governar, morreu, não teve sorte, José Sarney foi quem tomou posse! E botou o plano cruzado. Esse agüentou talvez um ano, não chegou agüentar um ano, aí disparou que caiu mais do que o outro que já não era mais cruzado, aí fícou cada vez mais relaxado e aí só castigava mais o homem do campo! Eu não achei melhor a mudança desse dinheiro! Agora entro o real. Nós tivemos aqui o presidente Fernando Henrique que não mudou o dinheiro!

Até agora pra mim eu não vi vantagem, não vi vantagem de jeito nenhum! O governo agora acha que um salário mínimo é uma coisa medonha pra uma pessoa que precisa como eu e outros mais! Agora assim pra um deputado, uma pessoa que tem mais assim, ele não enxerga que o dinheiro é medonho! Aí que o dinheiro vai mesmo acabar porque pra eles dá muito, agora pra nós que necessita muito de uma ajuda é nada! Agora com o salário mínimo que tá aí é um absurdo, eles acham que é uma dinheirama! Mas eu acho que não seja esse dinheiro um salário! Porque a pessoa se ela se hospedar ali em Porto Velho num hotel com banheiro é oito reais a diária. Pra quem ganha um salário mínimo se desloca para um lugar desse não dá de jeito nenhum nem pra dormir, só vinte dias já ultrapassa o cento e vinte reais, que já vai dá uns cento e sessenta mais ou menos só os vinte dias! Agora tá com um mês que estou com uma receita pra comprar um remédio que precisa comprar e eu não sei o que fazer! Não tem como! O sujeito fica na pior! E muitos passam pra viver nas rodoviárias, naqueles bancos! Os mais fracos acaba assim derrotadamente! O cabra chegou ali 
não tem mais como pagar nada, não tem mais como se sustentar! Eu não acho que esse dinheiro tenha valor não! ${ }^{108}$

Mas bem quando foi pra eu ir pra aula eu passei bem uma semana recebendo conselho pra aprender a tratar os mais velhos e aprender a tratar o professor. Para quando chegar na escola tirar o chapéu da cabeça e dá bom dia pra ele e alguma coisa que ele dissesse contra agente a pessoa ficar calado e não responder e se respondesse e viesse uma queixa pra casa ia sair mais caro pra gente. Foi minha mãe que me disse essas coisas e quando eu lembro disso eu acho graça, tenho vontade de rir! E dizia ainda que na hora que chegar qualquer pessoa na escola a pessoa se alevanta, não vai se levantar só se um se levantar não, você pode se levantar primeiro. E eu me levantava logo porque podia mandar um bilhete lá pra casa porque eu não quis me levantar! E aí a barra ia ser pesada porque naquele tempo pai e mãe não tinha dó de ninguém não. A minha mãe era uma pernambucana que dava uma média de 95 quilos, então tinha a altura que dava um metro e oitenta, deixando assim a munheca num caboclo que nem eu! A peia cantava bonita! E na carta de ABC que eu tava estudando tinha escrito que "quem não ouve conselho rara vez acerta" e era mesmo se você num ligou, num prestou atenção entra na peia. E entrava mesmo! ${ }^{109}$

E o que é certo é que eu achei a escola pra mim um pouco estranha e ficava nervoso quando chegava e tinha medo do mestre que tinha logo uma palmatória. Às vezes ela ficava em cima da mesa e quando ele falava já era um ditado e virava com tanta da pressa que fazia errar! Ave Maria! Eu sabia da minha lição assim no Bê-á-bá, sabia corretamente, mas quando eu chegava na ocasião de passar a lição na frente dele, porque antes o aluno se levantava e ia lá na frente, nos pés do mestre! E quando eu chegava nos pés dele passava a lição Cadê? Em casa sabia mas na frente dele não sabe mais, aí começava a falhar mesmo! Aí não tinha boca entrava na peia era um bolo numa mão e outro na outra. Passava pra outro aluno e aí mandava eu passar pra frente de novo que era pra só sair de lá quando desse a lição! Se não desse vinha novamente. Se não desse de novo quando chegava onze horas ele soltava os alunos e a gente ficava. E tinha ocasião que o camarada não dava a lição e ele pegava uma tábua assim da largura dessa mesa e semeava uns carocinhos de milho em cima e colocava de joelho que era pra dor ser cada vez mais no joelho, aí quando fosse assim uma hora ele soltava o aluno pra ir pra casa, aí quando chegava em casa não tinha boca entrava na peia. Apanhava na escola e apanhava em casa também! Já que você não estuda, não faz o que o mestre manda tome peia!

A primeira escola que eu fui foi 1928 em Aurora. Fui com cinco anos. Era nove quilômetros de estrada, tinha que sair cedo e andar a pé correndo pelo caminho pra chegar porque se chegasse fora da hora também o professor mandava pra trás e mandava um bilhetinho. Eu ía com mais quatro irmãos, uma mocinha e numa ocasião ele deu um bolo nela que quebrou um anel de ouro que 
ela tinha no dedo, colocou a mão na mesa, encima da mesa e bateu com a palmatória, quebrou o anel. Ela foi se queixar lá em casa, e disseram: “- não, você que não é estudiosa, o mestre sabe o que tá fazendo e aí você tem que aprender, quando você aprender um dia você vai agradecer esse bolo que você pegou". Ainda dava razão pra ele. O camarada não tinha pra onde correr.

Nessa escola não tinha farda não, a gente pagava por mês e não tinha farda. Agora eu estudei no Duque de Caxias em Cascavel e lá tinha farda, era farda com uma blusa vermelha, a manga comprida, com sete botões! Na calça aquele colchete, a calça era caqui e tinha o sapato.

$\mathrm{Na}$ primeira vez que eu fui escrever pegaram na minha mão, botaram o lápis entre meus dedos, pegaram na minha mão e botaram em cima do papel e vai guiando a mão. Pega em cima da mão da gente, principalmente pra cobrir o rascunho aqui a gente faz a letra de tinta pra gente cobrir com lápis, a gente chama rascunho. $\mathrm{O}$ translado também aquele que bota a escrita, as letras tudinho na frente da gente e a gente traz aquela letra pra cá pro papel, isso chama transladar, muita vez ele pegava na minha mão porque eu fazia aquelas letras e porque tinha a letra meia ruim, desengonçada, muita aberta, eu achava difícil levar a munheca pra ali e pra acolá, mas sempre quebrava um galho. E depois disso aí já era o ditado e a gente já tava mais adiantado, eu escrevia melhor! E agora ensinava os pontos, ah! Colocar os pontos que ali naquele ponto terminava a frase dando sentido e finalizando aquela frase. Perguntando, interrogando é a interrogação, agora admiração, se admirando, é exclamação de quem tá exclamando e assim vai e agora o ponto final sempre no meio da pauta. Começar na outra linha com letra maiúscula e assim era as explicações que eles davam pra gente assim, uma vírgula abaixa a voz, mas não pára, no ponto pára. ${ }^{110}$

Quando eu saí da carta de ABC eu já tava lendo um pouco arrastado, mas as letras do nome da carta que a carta tem o $\mathrm{ABC}$, depois tem o bê-á-bá! Aí tem uns nomezinhos, umas três páginas mais ou menos de nome e comecei mesmo foi na cartilha. Da primeira cartilha até na segunda eu ainda passava por cima, às vezes, de uma vírgula, de um ponto, de uma coisa, ainda não lia corretamente. Eu Lia Falando. Mas não sabia aonde era de parar aquele assunto. E assim muitas vezes a leitura fica incompreensível! A gente tem que parar quando tem um ponto, quando tem uma vírgula, abaixar a voz. E eu passava por cima de tudo e aí faltava a memória, não tinha compreensão pra isso, agora adepois que eu peguei a segunda cartilha, a "Proença", foi que eu fui conhecendo os pontos e lendo corretamente, lendo corretamente, aí li um livro "Coração de Criança", também muito bom!

A lição era marcada pelo professor, ele marcava ali às vezes seis capítulo, até fazer um ponto final naquele assunto que começou no livro, ele marcava até ali e fazia um x. Às vezes lá na mesa ele pegava o livro, o mesmo livro que o meu e mandava ler! E eu lendo na classe e ele nunca me 
reprovava porque onde era pra abaixar a voz ali na vírgula eu abaixava e aonde tinha o ponto eu parava um pouquinho e aonde era o ponto final eu parava com mais força.

Em casa eu sempre estudava assim ao meio dia. Pegava o livro e ia ler as lição já marcando as que eu sabia que ele ia marcar pro outro dia. Eu lia adiantado! Lia falando, falando assim, falando sozinho, que é pra gente ler e ouvir o que a gente tá lendo. Porque a gente lendo baixinho não entende bem e falando a gente sabe bem aonde tem que dá uma parada após a vírgula! E eu ia lendo, falando alto aquela parte que eu sabia que ele ia marcar no outro dia! Quando o professor ia, eu já tava bem traquejado na leitura. Era um caminho pra ficar afiado! Eu já tinha lido a lição um pouco de vez que era pra não errar, que ele reclamava muito, quando errava! Antigamente o estudo era rigoroso, hoje em dia que é fácil, hoje em dia não se vê muita coisa.

O magistério foi o General Humberto de Alencar Castelo Branco que montou. Mudou, tirou o nosso estudo e botou o magistério, antes era formação de pessoal, aí ele tirou pro magistério, que é formação de professores. Eu acho que foi isso que aperreou muito, atrapalhou tudo e é o que faz com que hoje em dia com pouco estudo uma pessoa pode se formar! E na formação de pessoal era duro, era duro!

Agora de 1941 pra 1942 eu lia sem falar, lia calado, todo livro que eu pegava eu lia comigo mesmo! Fosse mesmo obrigação ou se fosse do meu interesse mesmo pra ler, mas eu lia sempre! De repente passei a ler sem falar, só pra levar aquilo gravado na memória. Pelo menos assim a aritmética, a geografia que tem muitas perguntas e as respostas são complicadas, aí o camarada lia calado que era pra decorar! ${ }^{111}$

Aprendi isso em casa que era pra quando chegasse na escola eu sabia o que ler, já tinha lido bem, calado mesmo, sem falar, só gravando na memória! Aonde fosse negócio pra resposta que é o que encabula mais a pessoa, quando não sabia responder! Ficava ali calado, lendo, porque eu sintoniza mais um pouco, presta um pouco mais de atenção porque quando chega lá tinha muita pergunta. Era o problema e a solução para as perguntas e respostas e a gente lia calado pra poder gravar na memória que a gente na hora que precisasse tava tudo decorado, porque lê falando a gente grava, mas lendo calado fica melhor! Fica melhor porque já tá ali gravado, falando desabafa um pouco e a gente ficando calado assim lendo um livro à gente fixa mais.

Os meus livro foram História do Brasil e a Geografia da Terra, Gramática e Aritmética. A Gramática é pra gente aprender a falar bem o nosso português. Ensina os tratamentos, aprende a tratar as autoridades, ensina tudo! Ensina a fazer carta familiar e todos os tipos de carta! E tem também a caligrafia que ensinava a fazer letra do jeito que a gente quisesse ficar com a letra! Ensinava também o sistema da letra, a letra bonita. Nela a gente aprendia também a fazer letra. Agora a aritmética é a matemática, que é só pra negócio de conta e isso aí é uma confusão medonha! 
Hoje em dia eu já perdi muito porque saí dos estudos com 17 anos e tô com 76. Eu nasci no dia 19 de abril de 1923, no dia do índio. Do tempo que eu saí dos estudos pra uma época dessa sem me servir pros estudos ainda tenho muita memória pra saber o que é que se faz! Tive estudo até mais ou menos, porque os três anos naquele tempo não eram moles! Vale muito mais do que esse negócio de seis série, do primeiro e do segundo grau, vale muito mais! Hoje em dia eu somo, multiplico, divido, tiro as provas corretas, a prova real, um tipo de prova real, só precisa mesmo de duas que é na de somar e na de diminuir. Eu também aprendi naquela época que o professor ensinava pra gente que a conta toda ela são quatro operações, agora todas elas tem dois nomes somar é adição, diminuir é subtração, dividir é divisão e multiplicar é multiplicação! O resultado da conta de somar, porque somar é reunir o valor de muitos números em um só e o resultado dessa operação chama-se soma. Diminuir é uma operação pela qual se extrai o número menor do número maior e o resultado dessa operação chama-se resto porque sobrou. Agora a divisão é a operação pela qual quer se saber quantas vezes um número contém o outro, a gente diz assim: "cinco vezes quatro é 20 , aí já sabe que o resultado dessa operação é quociente. Agora multiplicar é a operação pela qual multiplicasse um número pelo outro quantas vezes seja preciso e o resultado dessa operação chama-se produto. Porque produziu de cinco vezes seis, trinta o produto! Isso é exato! Agora dividir, diminuir e somar tem que tirar a prova real, porque dizem que a prova dos nove mente, mas mente que eu sei como uma coisa que faz é roubar pra prova dá certo!”.

Aprendi a conhecer os números da numeração que são nove isso achei até fácil porque na escola que eu estudei ainda pintaram o romano, o algarismo romano, difícil, Ave Maria, pra saber o nome de uma data era um absurdo de tanta da letra, o sujeito bota um I vale 1 , o V vale 5 , um X vale 10 , um $L$ vale 50 , um $C$ vale 100 , um $M$ vale 1.000 , um $L$ vale 50 , um $M$ vale 1.000 , agora um $M$ com um traço por cima vale um milhão, e assim, eu fui escrever a data de $1942 \mathrm{em}$ algarismo romano, aí eu fui juntando, via o número 1 , o nove, número 2 , número 4 e via as coisas na mesa, via que tinha duas, via que tinha quatro, o professor é que ensinou isso! Ele em muitas ocasiões botava anotado pra gente, cada um separando e tinha que conhecer bem a numeração, agora ainda lia assim se fosse pra numeração pra dinheiro vinha a unidade, dezena, centena, milhar, dezena de milhar e milhão, que era pra gente se entender pra saber quanto é que tava aquela numeração, agora pra conhecer era do começo mesmo a gente começava e ele explicava bem pra gente entender que era um, depois era um dois, um três, um quatro, um cinco e assim a gente ia e quando chegasse no dez é que botava o zero à direita do um, era a numeração! E tinha número par, impar, misto, inteiro, quebrado é o misto, a fração ordinária, concreto e abstrato, isso tudo ele ensinava pra gente.

Agora História do Brasil eu li demais! Eu estudei. Eu ainda me recordo de umas datas que eu acho mais importante que nós tem: 1822 no dia Sete de Setembro - Independência do Brasil, isso aí 
na história. 1888 no três de maio - Libertação dos Escravos pela Princesa Isabel. 1889 Proclamação da República por Marechal Deodoro, que no dia 15 de novembro, mandou D. Pedro II pra França.

O Professor começou a contar a História do Brasil puxando desde os primeiros governadores. O primeiro foi Tomé de Souza, adepois veio Duarte da Costa, aí veio Mem de Sá que governou 14 anos, Mem de Sá governou 14 anos. Um tempo desses se falou da ditadura de Getúlio que era coisa inventada, e eu disse isso já se vem do começou, esse que eu já falei o Mem de Sá governou o Brasil 14 anos, e todos eles foram feliz só não o Duarte da Costa porque um filho dele D. Álvaro fez aí uma desordem pela colônia e foi chamado a Portugal pelo rei Dom Manuel e se nalfragaram no mar e parece que encostaram numa praia e aqueles índios caetés que são antropófago que quer dizer que come a carne humana, pegaram ele! As minhas aulas de História sempre eram perguntas, sempre era pergunta!

Perguntava quem descobriu o Brasil?

Aí o aluno dizia:

- Pedro Álvares Cabral

- Diga em que ano!

- No dia 22 de abril de 1500.

- Como foi que se deu esse acontecimento?

- O Cabral viajava para as Índias, afastou-se um pouco das costa da África, desconhecendo as correntes oceânicas aí encostou-se a essa terra calculando ele ser uma grande ilha, ele deu o nome dela de Ilha de Vera Cruz, a mais tarde virou Terra de Santa Cruz, e depois por causa de uma madeira cor de brasa, que é o Pau Brasil que já tinha sido explorada pelos espanhóis, por causa da cor de brasa veio o nome de Brasil! E se não me falha um pouco a memória foi Tomé de Souza que quando veio trouxe 400 soldados, 600 degredados e 6 jesuítas e a chefia desses padres era o Padre Manoel da Nóbrega que foi em 1554 e tinha o Padre José de Anchieta. Era assim as lições de História!

O professor dizia que antes de Getúlio quem governava era o Artur Bernardes, e foi quando ele assumiu em 1935, que rolou aquela revolução medonha! E os professores elogiavam muito porque ele logo antes da ditadura, com dois anos de governo mais ou menos ele criou o salário mínimo, valorizou o café, abriu os portos pro comércio estrangeiro e fez a abertura das escolas, das aulas pra toda pessoa. Uma moça se formava no quinto ano e ele dava a cadeira pra ela lecionar em qualquer município, naqueles arredores, nos vilarejos pequenos e mandava a professora ir pra lá. E antes não era assim de jeito nenhum! Antes o sujeito tinha que pagar um tanto e era difícil! E rápido chegou muita abundância para o professor! No grupo aonde eu via que eu não tava mais estudando 
se formava todo ano 15 ou 16 professores. Eram quintanista, na formatura arrumava um doutor pra ser o padrinho dela pra garantir que tirava o retrato e entregava o diploma pra ela. Isso ele fez de bom!

Naqueles tempos da ditadura de Getúlio Vargas a gente pode dizer assim que o Brasil dependia muito dos Estados Unidos e o comunismo tava apertando muito a Rússia e a China, que a população era a maior do mundo! A Rússia era uma potência grande perseguindo sempre pra implantar o comunismo no Brasil! E o Brasil tava cheinho de comunista! Até aquele Tenente Luís Carlos Prestes, preso, não podia sair daqui e se o comunismo entrasse no Brasil era ele o presidente com toda certeza mas ele nunca teve esse gosto, morreu e nunca teve esse gostou. E o que é certo é que o Getúlio era contra o comunismo demais, se ele abrisse mão como já houve em 1935 que teve a Intentona Comunista, teve medo de entregar pra outro e naquele tempo achou fácil dá um golpe de Estado e deu! Mas eu tenho toda certeza que isso aí era prevendo um prejuízo maior porque ele imaginava que podia abrir a mão do pode e entrar um camarada que adotasse a Rússia ou Cuba, ou a China ou a Coréia do Norte que não era do Japão, a Albânia comunista, a Iugoslávia também que é cinco nação, com o General Tito, comunista mesmo fervoroso. E Getúlio tinha medo disso! É tanto que uns disse que foi ambição, mas eu acho que não, era respeito pelo país que ele tinha, o Getúlio foi um gaúcho muito bom para o Brasil, homem de fibra, Getúlio um homem de fibra, e com um respeito medonho, ele era correto, não bebia! Eu tenho certeza que ele deu um golpe de Estado pra governar esses 14 anos foi com medo de entregar o país ao comunismo.

Teve também uma briga com Getúlio e Osvaldo Aranha quando tiveram que mandar os nordestino pra Amazônia! O Osvaldo Aranha foi o Ministro da Fazenda naquele tempo, e foi o primeiro ministro brasileiro que falou nas nações unidas. O Getúlio Vargas tinha fechado esse negócio de entregar a Amazônia por dez anos ao americano enquanto tivesse em guerra. Quando terminasse a guerra o americano restituiria o Estado pro Brasil de novo, mas o ministro quando chegou de lá achou que isse aí era capaz de haver um cambalacho e não dá certo, aí desfez tudinho que Getúlio fez!

E interditaram Getúlio que ele ficou como fizeram com o Collor e o negócio foi desfeito porque o ministro disse que se entregar o Amazonas pro americano desproprietarizando os patrões do Amazonas que são proprietários brasileiros e entregar pro americano, quando chegar o fim do contrato ele já tá lá bem firmado e não entrega mais de volta e assim derrubaram. Foi aí que foi começando a derrotazinha de Getúlio, que fez esse negócio mal feito porque se entregasse, eles não devolveriam mais e o ministro mostrou que tinha muita compreensão.

Lembro ainda da carta dele! Ele reclamou na carta dizendo que tinha feito muitas coisas, criado o salário mínimo, tinha feito a abertura e fizeram com ele como quem faz com as aves de 
rapina e por isso obrigou ele agora a sair da vida para entrar para a História, em agosto de 1954. Dizem que foi ele que se matou, mas muitos dizem que não foi, porque primeiro houve aquelas divergências grandes e porque tinha o Tenente Gregório que foi bem dizer cria do Getúlio que na casa dele era bem dizer um guarda costa ou um capanga, era perigoso! Um tempo aqui em Porto Velho quando Getúlio Vargas veio na cidade, mais uns dois ministros, uma moça jogou um papel, um bilhete para o Getúlio e o Tenente Gregório jogou a mão que o papel foi cair longe, tinha um coitado que chegou e deu um cacho de uva pra Getúlio, primeiro veio ele e comeu bem umas cinco uvas pra depois dá pra Getúlio pra ver se não era traição!

Aí começou aquelas divergências dele mais Carlos Lacerda que era um grande jornalista, que até foi governador do Rio. Pois bem, e ele mandou o tenente matar Carlos Lacerda que já tava atrapalhando. Mas o Gregório errou e as balas atingiram o Major Rubens Vaz. E aí Getúlio foi se derrotando! Todo mundo ficou sabendo disso. Como se diz foi oficiado mesmo, matou o Major, mas era pra matar Carlos Lacerda que ficou são! O Outro pobre é quem levou a bala.

O Tenente Gregório foi preso e toda vida que teve na cadeia não tinha direito a falar! Mas o Carlos Lacerda continuou falando e aí foi que falou mesmo! Até que arrumaram direito que um grupo desses de extermínio matassem ele logo na cadeia! E Getúlio Vargas foi se derrotando, desmantelouse e se matou até que veio aquele vice Café Filho. Dizem que foi Getúlio que se matou, se suicidou!

O Brasil tava um pouco quente, Café Filho tirou tempo todo de governo dele no hospital com medo de sair porque o povo matava. Ele não veio pro Palácio! O vice presidente virou presidente porque o Getúlio morreu, mas eu acho que ele foi matado! Aquela carta que ele escreveu foi muito bem feita por uma pessoa de boa, bom assunto, boa idéia! Fez ela de um jeito que lendo a carta toda tinha muita gente que chorava, ficava emocionado! Mexia um pouco com a pessoa, carta bem feita, até que no fim "eu saio da vida para entrar na História”.

Eu gostava dele muito, porque quando ele entrou, eu ainda tinha muito pouca compreensão, mas tinha uma razão que eu já enxergava muita vantagem no que ele fez.

Até hoje eu só tenho raiva dele porque ele matou Lampião. Lampião pra mim era um homem honesto e começou aquela desavença ali em Pernambuco entre ele e aquela família dos Nogueiras. Os Nogueiras acabaram com a família de Lampião, escapou algum que não tava em casa. Lampião com toda nobreza se muniu com um rifle e um bornal de palha e matou os cabras que mataram o pai e a mãe, matou tudinho e ainda matou uns soldados e não quis se entregar. ganhou o mato! Para mim ele foi um herói, mas não era pra ser matado! Nunca ele fez nada no Ceará, ele era afilhado de Padre Cícero, fazia era encher a barriga daquele povo pobre. ${ }^{112}$ Muitos eram gente falsa. Quando ele dava as costas iam dá parte dele, dizer que Lampião tava aqui! Aí a polícia ia era trocar bala, era uma bala medonha lá na mata, é bala correndo! Ele levou uma vida agitada até que aturou 
14 anos na mata. Mataram ele! A polícia alagoana matou no Sergipe em 1931. O negócio é que naquele tempo Getúlio era duro, bandido assim e comunista sofria na mão de Getúlio e se ele não faz isso o Brasil caía mesmo! Teve até em 35 aquele movimento do comunismo lá do Rio de Janeiro, do terceiro regimento de infantaria que foi acabado, bombardeado! A Rússia ali insistindo e Getúlio tinha a munheca dura! Gaúcho não tinha dó de ninguém não!

O presidente era Jânio Quadros um mato-grossense mesmo de fama, homem honrando e pôs muita lei no país acabando com negócio de nepotismo que é colocar parente pra trabalhar no governo, era o que havia muito! E o Jânio Quadros acabou com isso tudo. Cortou uma pessoa viver com não sei quantos emprego e as outras pessoas que viviam com maquinário do governo se servindo delas e não dava pra pobreza.

Os pobres gostaram muito, mas os grandes derrubaram a lei que ele implantou, aí ele mesmo renunciou! Então teve que anular. Aí Jango, não tava com três anos mais ou menos, criou aquela reforma sindicalista e através desta reforma é que vinha o comunismo. Só faltava um ministro pra assinar. O que é certo é que a mulher dele ainda fez fala pra que se fizesse assinatura, que o marido dela era um homem muito honesto. Mas aí o Marechal Humberto de Alencar Castelo Branco, um cearense velho que era ministro da guerra naquele tempo tomou posse. Logo ele botou João Goulart pra fora. E implantou a lei da ditadura militar, mas que pra mim foi o regime melhor. Ainda foi melhor que a de Getúlio. Porque ali também tinha uma munheca dura de militar e não tinha burocracia, não tinha burocracia. Eu pelo menos sou um aposentado da FUNRURAL desde de 1956. Recebi até com nove mês em qualquer banco em Porto Velho. Aonde hoje em dia o camarada fica com dois mês, se passou de dois meses tem que renovar o documento tudinho. Renovar no INSS, quer dizer que a burocracia tomou conta e no militar não tinha isso. Eles construíram muitas coisas, aquela hidrelétrica de Itaipu. Desde que eu comecei com termo de razão que era comentado esse assunto, agora ela foi realizada com o Ernesto Geisel. Tucuruí ninguém nem falava que foi feita por ele. Três volantes cada uma dava duzentas mil toneladas isso aí é um absurdo, só mesmo os militar mesmo que pode fazer uma coisa dessa. A de São Francisco tomou terra de quatro município no Estado da Bahia e Pernambuco. Só pode ser construída desse jeito, mas construiu. Foi Ernesto Geisel. Foi construída e hoje em dia tá dando resultado e servindo muito e tantas coisas que eles fizeram. Agora as cidades crescem rápido. Se espalham.

Em 43 quando eu saí do Ceará passei por terra pelo Piauí, ali na Extrema. Quando vim pro Maranhão a primeira cidade que nós paremos foi Coroatá, um vilarejo. Hoje em dia tem rádio transmitindo até pro inferno ... pra todo canto do mundo. Abacabá, outra cidadezinha que não valia nada, Santa Inês, isso tudo tem rádio hoje em dia transmitindo. Aqui mesmo tem Rolim de Moura, tem Costa Marques, tudo isso tem rádio. Isso aí só os militar mesmo, são os homens que não tem 
pena ${ }^{103}$. Agora disseram:- ah mas o Brasil ficou devendo uma conta muito grande. Ficou devendo, mas a gente vê que o Brasil desenvolveu, as cidades cresceram, a capital tá mais elevada. No tempo do Juscelino quase não tinha nenhuma fábrica de carro, Juscelino foi quem botou a primeira fábrica de carro no Brasil. Hoje em dia nós temo a Embraer de avião e tanta coisa que já botaram, Ave Maria, eu acho muita vantagem nos militar, fizeram muito pelo Brasil. Porto Velho, o tamanho que era Porto Velho antes dos militar, não era tamanho de nada. Aquele Teixerão foi governo aqui, primeiro que tinha sido prefeito de Manaus e botou Manaus pra frente, veio aqui pra ser governo daqui e hoje em dia tá um Estado do tamanho de São Paulo ou maior, Rondônia, tomou terra do Amazonas, tomou terra do Mato Grosso, porque os militar o que quer faz, e como eles quiseram interromper a usina de São Francisco mas o Geisel não deixou. Não! As terras que nós ocupar pra construir a usina aqui bota a cidade no outro canto, constrói outra cidade, mas tem que ser feito.

E fizeram mesmo e dá dando valor e tá dando prestígio para o Estado e para o Brasil. Isso aqui, a gente puxando atrás, pode falar qualquer coisa? Pois bem, a gente mudando pra rei, o que os reis fizeram pro Brasil desde 1808 que eles tomaram pose no Brasil com o velho D. João VI pai de D. Pedro II, o que é que ele fez? D. Pedro II reinou quase 45 anos no Brasil mas se deixou algum caminho, caminho tem até demais, outra coisa ele não fez não. Quando o Marechal Deodoro tomou conta já é uma grande coisa, criou o Estado civil que nós não tinha naquele tempo nós só era eclesiástico da igreja, a gente chegava num lugar e ia falar qualquer coisa, primeiro ia com o padre vigário daquela freguesia. Tudo era com o vigário. Que era pra ver o que o senhor padre dizia pra gente poder ir no prefeito ou delegado, era assim. Marechal foi e criou o Estado civil, quando foi em 1935 criou o casamento civil, cansei de ver na igreja o padre dizer:

- Guerra para o civil, porque esse civil não vale nada.

A pessoa casada no civil é considerada emancebada porque o padre considerava emancebada. Já agora em 1960 um filho meu foi batizado, um filho que nasceu e que morreu, foi batizado e crismado e o padre vinha fazendo casamento civil, o mesmo padre trazia o escrivão pra fazer o casamento. Quer dizer que aí ele cedeu um pouco, ele viu que o civil manda mais e a gente sem documento sendo casado católico é solteiro. Só no civil é mais coisa.

A Segunda Guerra Mundial começou em $1939^{104}$. O primeiro Estado que a Alemanha tomou foi a Polônia e aí foi se estabilizando e quando ele veio ser derrotado ele já tava com quatorze ou dezessete bandeiras que ele já tinha conquistado. Deu um ataque na Rússia, no Estado Maior mais elevado. Naquele tempo o presidente da Rússia era o Marechal Stalin mas ele não estava prevenido pra guerra não, não tava esperando um ataque daqueles, com dois ataque que ele deu quase que se derrota em Stalingrado. E ainda mandou um recado para o Marechal Stálin que no outro dia nove horas mais ou menos ia tomar um café com ele lá. 
O alemão matou vinte e seis milhão de russos, matou com Hitler, com o governo da Alemanha, o chefe da Revolução na Segunda Guerra Mundial. Ele deu dois ataque na Inglaterra, naquele tempo era o Rei Jorge VI, era o marido da rainha Elisabete. Deu dois ataques e deixou a Inglaterra em caos. O rei Jorge VI se valeu de um General velho chamado Churchil um homem de muita tática de guerra, de revolução, dessas coisas, e ele tinha muita prática. Era do tempo que os Estados Unidos foram colônia da Inglaterra, e os Estados Unidos se libertou a custo de pau e venceu a Inglaterra e se tornou a maior potência do mundo, mas foi colônia da Inglaterra. O Marechal Stalim viu que se não tomasse a providência severa a vaca ia pro brejo, aí bateu mesmo no Alemão e fez ele recuar. Ali não tinha ponto estratégico pra ele e ali sem meio, sem acesso de atacar por terra ele tirou da Iugoslávia que lá o governo era de um general também de munheca dura, um comunista. Lá o alemão perdeu doze bateria de guerra. Ficou um reduto. Ficou preso e de lá não saiu mais ninguém, até um generazão que era de fama morreu lá. Era um dos perna forte de Adolf Hitler. Aí ficou. Nessa mesma época o americano botou uma bomba atômica em Hiroxima no Japão e botou outra em Nagazaki também. Porque o rei do Japão estava apoiando o Alemão também. Traiçoeiro, tava apoiando, dando essa entrada. Agora o americano combinou com as nações, em nome de todas, foi uma coisa combinada, bem raciocinada pra botar essa bomba. Até hoje morre gente por causa disso. E tem aleijado lá. A Rússia botou que era pra interromper o avanço do alemão por lá. Ficou o reduto do alemão em Monte Castelo. Foi quando foi a força expedicionário do Brasil. Na primeira remessa foi trinta e cinco homens. E se criou esse Soldado da Borracha, porque o Brasil dependia muito da Borracha e os Estados Unidos era o que mais precisava da borracha. Na guerra tinha muita coisa. Lá em Monte Castelo o alemão foi derrotado desgraçadamente e nossas forças tava sendo derrotada por causa daquele General Mascarenha de Moraes, um baiano que botou nosso soldado lá. Pra o americano é fácil. A força expedicionário não tinha muita prática de guerra, tudo gente jovem daqui do Brasil. O Brasil nunca brigou e se colocaram mal. Os Estados Unidos ficou na retaguarda e o Brasil na linha de frente, tava morrendo tudinho. Eu vi foi no cinema, tava morrendo os homens, caia assim pra frente saia fazendo careta e o sangue descendo na bala do alemão. Tinha aquele Generaozão Góis Monteiro, que era chefe do Estado Maior do Exército do Brasil, chegou e empurrou as forças do Brasil, que tava no domínio desse Mascarenha de Moraes. Na hora que ele recuou o Alemão peitou no Americano, quando peitou o Generaozão de Brigada do Americano gritou. Na hora do aperto o Brasil fugiu, o Brasil recuou, aí o Góis Monteiro que era um alagoano gente fina, ele disse:

- Não, a força, a tropa do Brasil recuou porque tinha ordem superior, porque colocaram eles em linha de frente e os outros ficaram na retaguarda e aqui tem que ser é pra todos, aqui tem que ser um por um e um por todos, não é só botar uma nação na frente pra pegar o exército da Alemanha. 
E assim foi que fizeram, mas com isso aí o americano entrou na bala também. Chegou a cair mas tava experimentando só o Brasil. São falsos essa gente, são bons mas são falsos. A gente sabe que a diferença é que tem pena de morte. O que é certo é que daí de Monte Castelo ele foi derrotado, foi derrotado pelo menos em 1945, em agosto de 45 mais ou menos, aí ajuntou a Rússia, ajuntou a França, ajuntou a Itália, ajuntou a Rússia, aí vieram tudo de uma vez descarregar bomba em Berlim. Em Berlim não se ouvia mais nada era só pipoco de bomba e fumaça de casa em casa, e acabou destruída. Aí foi proclamado o fim da guerra, a tanto de agosto de 1945.

Daquele filme sobre a guerra eu não tenho lembrança do nome, mas eu sei que tudo era provindo da guerra. Foi lá no Ceará que passava o filme. Eu ainda passei três anos de guerra no Ceará que ela começou em 39, e eu vim pra cá em 43. Eles filmavam lá e traziam para mostrar no cinema, e fazia dó a gente vê, me deu uma pena de ver a pessoa morrer. Ali é uma situação terrível. Muitos que tavam de assistência ali salvava a vida dele, mas era um trovejo de fogo medonho que não tinha quem tomasse. O povo alemão era feroz demais e as armas deles era medonha, desde a primeira guerra em 1914. Os outros ficaram no que eram e eles se prevenindo esse tempo todinho, porque antes dele começar a guerra disse que só há um só Deus e um só Governo. Quem não se sujeita a ele pra se identificar ia ser queimado como a gente queima as galinhas no nordeste. Ele era malvado. Por isso acabaram com eles e acabaram com Berlim. Berlim foi reconstruída depois mas eles acabaram.

Isso tudo eu sei é porque eu tenho muita memória e assistia muito rádio, ia no cinema e muitas pessoas que tava no meio conversava também, e aquilo em mim fica gravado e no dia que precisa eu posso declamar que é assim. Eu não lia nada dessas coisas, mas eu via e ouvia, eu vivia. Via e ouvia mas em cinema. Eu vi bem umas três fitas da guerra e adepois muitas falas, pessoa fazendo comício ai explicando como era fácil de nós receber um ataque ${ }^{105}$. Aí no Rio Grande do Norte foi construída uma base em 1942, uma base aérea porque duas horas e poucos minutos ia pra a alemão atacar o Brasil, por água, pelo ar. Por terra não tem chance mas vinha por água, aí enfiaram uma base área muito elevada. Quando eu vim pra cá que eu tava lá no porto. O primeiro alistamento do Soldado da Borracha foi 74 mil pelo SEMTA, o verdadeiro soldado da borracha é o que veio pelo SEMTA que quer dizer Serviço Especial de Mobilização de Trabalho da Amazônia ${ }^{\mathbf{1 0 6}}$, essas iniciais significa isso. E eu vim pelo SEMTA porque lá tive que vender paletó, tive que vender calça, cinturão, gravata e tudo, chapéu, só não jóia. Tinha que vim com uma fardazinha muita ordinária, uma calça de mestre, uma camisinha de pano americano de algodãozinho fino, um chapéu de palha, um saco que só cabia uma rede com uma cobertinha pequena, um caneco grande e uma colher com um garfo na ponta do cabo, servia de garfo e servia de colher. O soldado da borracha não podia trazer mais outra coisa, só isso. Agora depois quem veio pela SABA e pela CAED são duas 
companhias a mais que com a SEMTA fazia três companhias. Era o SEMTA, a SABA e a CAED. O SEMTA foi o primeiro é esse que é o verdadeiro soldado da borracha. Os outros já trazia até mulher, isso aí não era mais soldado da borracha. Esses aí não eram mais soldados da borracha, podia trazer roupa, chegava tudo decente. Nós não tinha nada com o Exército, Soldado da Borracha, tinha carteira de terceira categoria, agora nós trazia dois jornalzinho pequeno um cor de rosa e o outro verde, agora um é conforme o contrato que o Getúlio Vargas assinou com o americano pra gente entregar pro americano e o outro pra gente ficar pra saber, pra conferir se o americano tava cumprindo com o negócio que ele fez com o Getúlio. Era assinado pelo Getúlio. Nós vinha pra cortar e o americano vinha pra criar posto. Eles são ricos podia dá uma ajuda com um aparelho, uma coisa pra gente se deslocar. Umas duas horas de viajem, a gente assim não pensa, duas horas era um castigo, tinha que levantar meia noite e não dava. A pessoa vinha por conta do americano, a borracha que tivesse saldo, que tivesse devendo, mas o americano só podia descontar $40 \%$ do produto do seringueiro assinado pelo Getúlio, eles não podia descontar mais, ele não podia, mesmo que algum soldado da borracha tivesse devendo a ele mas ele não podia abarcar aquele produto todo, tinha que tirar só 40\%, 60\% ficava pra nós os soldados da borracha.

O Ensino de antigamente era mais aprofundado porque era mais bem explicado as coisas e nos livros mesmo já vinha pra pessoa ver. Hoje em dia a gente tem que ler o livro e muitas coisas. A pessoa fica sem saber e tem que procurar a pessoa mais traquejada pra explicar aquilo e antigamente no livro vinha dizendo, facilitava mais pro aluno, ele tendo assim o terceiro ano já era uma pessoa que dava bem de conversar em qualquer canto com qualquer pessoa capacitada. Ele tava por dentro de tudo e sabia tratar e hoje em dia não se sabe. Um tempo desse eu ouvi no rádio um locutor perguntar pra uma menina lá em Rio Branco como era o nome do governo, e naquele tempo era Francisco Vanderlei Dantas. Ele perguntou como é o nome do nosso governador aqui do Estado de Rio Branco, ela disse:

- Eu não sei.

Aí o locutor disse assim: - Você estuda?

Ela disse: - Eu estudo.

- Aonde você estuda?

- Aqui no colégio das irmãs Dorotéia.

Que é aquelas de chapéu grande, chapéu branco. 
- Mas minha filha, que série você tem?

- Eu tô na quarta série.

- Mas minha filha você na quarta série e não sabe o nome do governador?

Por isso eu digo. Os nossos estudos nos livros mesmo naquele tempo tinha tudo explicado. Uma coisa explicava outra quase assim como um dicionário. A gente quando lia um livro ficava sabendo já de muitas coisas que era explicado. Hoje em dia a gente lê o livro mas se quiser saber de uma coisa mais aprofundada tem que perguntar ao que saiba mais. Aqui tem aluno do estudo do primeiro e segundo grau dessa escola, pode perguntar muita coisa aí que não sabem nada só sabe ler e escrever, muita coisa eles não tá por dentro. Por isso eu digo que os estudos antigamente a formação de pessoal era mais elevado ${ }^{107}$, para mim era mais elevado, era explicado, o professor dizia e explicava, hoje em dia eu imagino até que seja quase que uma inveja do professor. Porque a pessoa ler e escreve mas não tem uma explicação pra dá pra gente, a pessoa ler uma coisa e ainda vai perguntar a outro o que é, e antigamente não. Na tabuada na capa dela tinha trinta dias tem novembro, abril, junho e setembro, fevereiro vinte e oito tem, se for bissexto mais um que tem, e os mais que sete são trinta tão de férias, na capa da tabuada, hoje em dia você não vê mais isso. Pra escrever e lê eu não digo que seja bom mas pra saber de muitas coisas assim é preciso esse estudo desenvolver mais. Esse negócio do magistério eu vejo o atraso em tanta gente que diz que tem a sexta série que não sei o que, que o primeiro grau, já é um pouco elevado mas se puxar pra qualquer uma coisa assim ele não dá nada, se duvidar. Um tempo desses eu falando aqui no tempo do Mem de Sá e ninguém sabia de nada. 


\section{OS SONHOS}

"Mesmo doente a gente nunca sonha doente. A gente sempre sonha sadio..."

Quando eu saí de Aurora, que foi o lugar que eu nasci no dia 19 de abril de 1923, nós viemos para uma cidade de beira de praia chamada Cascavel. Aí sonhava toda noite com a minha terra natal, com saudade de todo aquele povo e sempre com vontade de vê tudo e realizar de novo tudo aquilo que eu já tinha feito, pegar boi na caatinga! Ah! Eu sonhava direitinho que eu estava lá, mas que tinha um rio no meio, que nunca eu chegava na morada onde eu nasci, porque justamente o rio impedia de eu voltar pra lá. No sonho, eu nunca pude voltar porque tinha esse rio no meio! ${ }^{108} \mathrm{Eu}$ vivia sonhando, mas eu sonhava do mesmo jeito, que vestia uma veste de couro e um tempo eu pedi ao meu pai pra ele comprar ali uns couros. Eu já tava com 17 anos e ele comprou não sei quantos couro de carneiro pra fazer um gibão pra mim. E eu sonhava que com essa roupa, quase toda noite! Eu corria atrás de gado e via meus camarada, mas eu do lado de cá do rio e eles do lado de lá, nunca eu sonhei, tive um sonho legal mesmo pra dizer assim que eu cruzar o rio pro lado de lá, pra morada que eu nasci, e de fato nunca fomos, ficamos aí na cidade de Cascavel.

Eu sonhava assim tanto que me acordava com aquela idéia de que tava lá, mas que não tava, tava mesmo em Cascavel, nunca eu fui pra lá, tudo isso era sonho que eu sonhava, porque eu queria muito bem ao meu lugar que eu nasci, a convivência, a vida na praia é tudo diferente! E sempre assim eu continuava sonhando, teve ocasião que eu sonhei lá pegando gado, e encurralando, ferrando aqueles garrotes, aqueles que nós chama "ponta-limpa", tudo queimando pra poder soltar. Quando me acordava, conversando com os camaradas antes de me levantar, aí me acordava era mal, aí eu ficava assim um pouco imaginando, mas sabia que tava acordado com os meus parentes tudo dentro de casa, pra mim tava tudo bem, não tinha deixado ninguém lá. Às vezes tinha sonho também servindo o exército, e isso aconteceu, se realizou! Aconteceu de eu ir pro quartel mas eu não recebi farda, passei 8 dias naquele quartel, desses batalhão de caçador, passei 8 dias lá. Mas houve uma confusão e a guerra se avançou e eu tive medo de sentar a praça e disseram que podia vir pro norte, era o mesmo que faria, aí eu preferi vir pra cá. Isso aí eu sonhei muito e foi realizado o sonho, vestia o verde oliva!

Sonhava que tava no quartel e no meia perna, aquele movimento todo, já tava acostumado a ver, fazendo aquele movimento todo e eu era um soldado mesmo. que naquele tempo tinha aquelas perneironas de botar, o calçado não era esse de hoje em dia, era vicuña, botava aquela caneleira e a farda verde e eu ficava muito satisfeito com aquele sonho, pra mim eu tava lá mesmo, quando acordava era nada. Aí o sujeito volta pra ser o que era, e assim continuava. Sempre eu tinha sonho, 
sonhei que vim aqui pro norte num tempo, mas muito antes de eu pensar que vinha. Eu sonhava com um lugar muito esquisito, eu sozinho, vivia no meio da mata, aquela coisa, com vontade de ver uma pessoa conhecida, mas no sonho nunca pude ver, sempre que me acordava tava na selva, tava numa casa no meio da mata e quando me acordava tava em casa mesmo. Mas nesse sonho eu só via aquelas árvores, aquelas coisas muito verde, muito diferente do nosso torrão, porque no Ceará não tem tanta mata como tem aqui de jeito nenhum, e nem tanta água; só se for lá dentro do açude ou do mar, mas não pode consumir essa água. E isso tudo eu via! Aí na idade assim já de uns 18 anos mais ou menos, quando foi na idade de 20 anos lá se vem eu pra cá; quer dizer que esse sonho aí deu certo. Agora que não deu de eu vir como eu vinha no sonho. No sonho eu vinha assim no meio de uns conhecidos, aí depois me deixavam apear e eu acabei ficando só. E quando cheguei fiquei aqui no norte no meio da mata eu tava achando que tava perdido, e andava assim meio nervoso, vendo tanta árvore e paus desconhecido pra nós, cada árvore medonha! Então eu estranhei. Aí eu me acordava, sempre me acordava aperreado, aí me acordava!

Agora quando eu cheguei aqui só sonhava com lá. Sonhava era que eu chegava lá no sertão, Vixe Maria! Dando um abraço na minha mãe, numa morena que me criara que cuidava de nós. Nós chamava ela tia, ela era pernambucana também, minha mãe casou com 14 anos e levou ela pra casa pra servir de companhia. Porque naquele tempo o meu pai era assim um pouco ambulante, assim a vida dele, e pra ela ficar só tinha muito jagunço e ela tinha medo. Todas duas com 14 anos, a minha mãe e essa pernambucana também. Ela chamava Maria Valdina da Conceição. Tinha ela como uma segunda mãe. E eu sonhava vendo ela, me abraçando e aquela coisa, fazia aquela festa, ia ajuntando mala e trazia os presentes pra ela, quando ia distribuir não chegava entregar, eu acordava. Assim só pra deixar o sujeito no nada mesmo! Eu sonha muito, todas essas coisa, sonhava correndo em cavalo, eu fui jóquei de corrida de cavalo 4 anos, eu sonhava correndo com os cavalo, cavalgando em campulina grande, 12 palmos de altura, e no sonho eu ganhava a carreira, e no dia que acontecia do jeitinho que eu sonhava eu ganhava a corrida, apostas grandes até que fazia, o jóquei tem 10\%, então eu era bem gratificado. Pois é! Esses sonhos tudo eu tinha! Agora sonho assim meio aperreado por causa de traquinagem, apanhar do meu pai, sempre eu sonhava! Daqui e ali, tava sonhando levando uma surra. Sonhava que fazia alguma coisa, alguma trapalhada por lá, um tempo eu tava lá no sonho eu tava trepado num pé de abelha derrubando umas lá, aí ele brigou comigo, aí eu pensei que ele não ia fazer nada, quando eu entrei em casa ele me pegou pela mão e desceu o pé de peruca, um arreio de cinco pernas. Isso no sonho! E foi surra, foi peia como o diacho! E eu andar aperreado e gritei pedi pro povo me acudir, e até que teve um bocado que "ah seu Vicente deixa o menino, o senhor também é muito carrasco com ele", pois assim eu escapei no sonho.

Agora aqui hoje em dia eu tenho esse lugar meu daqui lá dá 226 quilômetros, quando eu vim pra cá ficou a casa ficou lá, fora que eu não sabia o que ia se assuceder isso de cortar a perna. E eu 
não pude voltar, carregaram tudo que eu tinha e eu fiquei. Eu queria muito bem lá porque tem limão, tem cupuaçu, tinha lima, laranja, muita coisa que eu plantei, fartura! Que eu plantava muita macaxeira. Agora eu sonho, quase toda noite eu sonhava com o meu lugar, quase toda noite, mas quando eu chego lá só vejo muito é gado, cheio de gado ali, uns burro velho magro.Um dia desse eu sonhei "mas rapaz será possível que esse povo quer mesmo invadir o meu lugar, só eu botando as unhas de fora aqui!" Aí quando dava bem vontade cheguei debaixo de um pé de limão que são vinte e quatro árvore de limão, eu passei por baixo, mas logo eu vi uma castanheira derrubada, aí eu fiquei um pouco injuriada e lá tinha umas 14 árvores dessa castanheira do Pará ao redor de casa que era conservada, desde que eu cheguei lá que tinha essas árvores, aí eu vi elas derrubadas assim fiquei um pouco raivoso; também logo me acordei. O meu caminho também quando eu ia atravessei um lugar com muita árvore por aqui assim que não tinha isso, tomei um banho lá dentro de um igapó que tem que eu nunca tomei, que o igapó tem lá dentro mas no sonho eu teria se banhado. E eu fui com esse meu lugar lá, que tá perdido! Mas eu sonho continuadamente, as vezes o menos que sai é dois sonhos por semana, eu sonhando lá, inventando aquelas coisas, mas as vezes eu chego lá eu só vejo é campo e outras vezes eu vejo a fartura, coqueiro, mangueira, maracujeira, cupuaçu, graviola, esse limão grande por cima, muitas coisas que tem, eu vejo! Mas tem ocasião que eu vou e não vejo nada. E às vezes tá trilhado de rastro de gado! E esse sonho é sempre, sempre, porque eu tenho muita saudade de lá 109. Porque lá eu cheguei lá em 1977, tá com 21 anos já, e agora em eu tô com um ano aqui e pouco, entrei aqui no dia 19 de março.

Pois é e os meus sonhos sempre são assim, agora sonhar com aventura, com essas coisas assim pra mim é muito raro, nunca eu sonho, sempre eu só sonho mais é aperreado. Às vezes no mato com medo de fera, essas coisas, medo de onça, levando carreira medonha, tenho sonhado muito correndo mesmo pra escapar, escapar já, pega não pega! E eu chego ali! Até que eu chego num lugar seguro mas já fico bem ali atemorizado mesmo, que tô vendo o bicho me pegar. Mas ultimamente eu tenho dormido pouco, que é pra não dá o pesadelo, porque se não acordar o pesadelo pega, aí vai ser uma zoada medonha.

Mesmo doente a gente nunca sonha doente. A gente sempre sonha sadio, sempre sonha sadio, nunca a pessoa sonha doente. Sonha correndo jogando bola, em festa, dançando, que eu dançava, até quando eu perdi a perna, que eu vim pra cá eu dançava aquelas festas lá pelo clube. Eu mesmo não tirava pra dançar, não, que eu sou um velho que conheço o meu lugar, mas as mulher mesmo sabiam que eu dançava bem e vinha tirar pra dançar, e eu que não vou desobedecer, e pra mim tudo é vantagem! Pois é isso aí acontece, eu vê aquele instrumento tocar e eu dançando ali e satisfeito. Aí quando me acordo já sabe é daquele jeito! Tudo tá me agarrando! E o sujeito fica assim, diz: "isso aí tá muito ruim de acontecer", porque quando a gente acorda leva logo pra perto, num tem mais jeito! O sujeito tem que se conformar com o que é dele. Mas que os meus sonhos sempre 
são assim eu nunca sonho com aventura! Só sonho mesmo conforme a vida. Cortando seringa, eu sonho cortando seringa, tem ocasião que eu faço assim tem borracha mais eu talho, tem até quatro e falta uma, eu sei que o meu patrão era rígido, se faltasse com aquela borracha prometida ele cortava a nota, e eu que me acordo no maior sufoco do mundo, que não deu de fazer as quatro, mas eu vou ver se dou um jeito, quando dá fé eu me acordava e aquilo ficava sempre, não realizava. Tudo isso a gente sonha. Sonhava que eu trabalhei abrindo seringal, abri seringal aí com o meu patrão na mata bruta, na mata virgem com nós chama, e eu que sonho o mesmo serviço, batendo nas madeiras assim que a gente o mateiro que era eu, trabalha bem no mato, fica, acha a madeira como daqui lá acolá, aí bate com o terçado na madeira assim tá, tá, tá., com o terçado, é um tinido bonito, aí toquei pro cara, responde, aí nós vamos emendar o que tem de lá pra cá. E assim nessa vida eu me acordo, aí eu trabalho no sonho, aí já cortamos duas, três estradas, uma estrada até de duzentas madeiras, e eu cortando tudo, e no sonho dá tudo certo! Eu corto a estrada mesmo completa.

Agora teve um sonho que eu fiquei assim meio impressionado porque eu tinha aberto uma colocação, era novato, e eu abri a colocação fazia pouco tempo, e lá tinha onça que ela esturrava assim bem pertinho de casa, agora eu não sou muito nervoso, eu tinha arma boa, revólver, tinha espingarda, faca também, peixeira; nordestino é a peixeira brava mesmo! Pois bem e eu quando fiz o campo pra fazer a casa eu derrubei uma árvore grande, que dois homens não abarcava! Aí eu fiz um tapiri, que a gente faz um tapiri pra se arranjar pra depois poder fazer uma casa maior, mas casa mal construída, de açaí o piso e as paredes, agora coberta em cima palha de babaçu. Pois bem, eu às vezes eu conto anedota que tinha muito meus camarada lá, tudo ainda era gente novo, e eu sai dormindo, desci o assoalho e tava lá assentado nesse pau conversando e contando anedota pra eles. Ih! era uma zoada, eles tudo achando graça eu contar aquelas piadas engraçadas, aquelas anedotas que eu sabia acordado e eu contando dormindo pra ele, no sonho! Aí até que com muita coisa, era bem uns 8 que nós tudo era vizinho perto um do outro, tava tudo reunido lá em casa, que era a casa que tinha mais assunto, ninguém passava sábado lá em casa, aí quando eu me acordei tava sentado em cima dessa árvore que nós chama Gameleira, é um árvore que dá leite, eu tava no escuro sem saber pra onde ficava a casa, eu só tinha no sonho! Agora quando eu acordei não sabia pra onde ficava a casa, porque era perto! Aí um escuro medonho, que o campo era pequeno, aí eu saí assim talvez fosse uma meia noite, aí eu saí assim e logo assim um Canbuçu abriu que era cada um berro, parecia um novilho zebu, e eu ainda aparentei mais um pouco, que no escuro, só de calção e sem uma arma sem nada. Aí eu sai "escorregendo" na árvore até chegar no tronco que o tronco tem assim umas sapupembas, umas tábuas grandes, e eu sabe que eu tando ali a minha casa tava pro lado contrário e assim eu consegui ir pra casa.

Isso tudo no sonho, foi mesmo, agora quando eu fui pra casa eu já tava acordado, agora eu me acordei contando anedota pros meus camaradas sentado tudinho nesse pau, nós tudinho, tava 
cheio a árvore desse pau, aí né começaram a rir muito, com o negócio de risada eu me acordei, me acordei tava sozinho no meio da mata sentado nessa árvore medonha, não sei como é que foi que eu me levantei da rede e dormindo e vim. Saí andando sozinho, dormindo, no meio os outros tava tudo em casa, sonhei assim, não sei como é que foi aquele sonho, sei que tava tudo ali, era muito camarada, bem uns oito, que tudo trabalhava perto lá de casa, quase todo dia tava indo lá. E eu de noite fui sonhar isso, e sai num sei, umas doze horas da noite saí e sentei lá nessa árvore que eu tinha derrubado, e pra mim tava no meio de todos os camaradas conversando e achando graça. Eu tava sonhando dentro da mata, tava lá, tava abrindo essa colocação pra mim e o campozinho pequeno, e noite de escuro, mato fecha de um lado e de outro, não tem, não tem quem enxergue nada, era bem meia noite e eu dormindo saí de dentro de casa, eu sozinho, e vim me sentar cá nesse pau contando anedota pro pessoal e eles riam! E era aquelas coisas. Tinha anedota engraçada, até meio imoral, e eu contando tudo dormindo, quando eu me acordei eu digo "agora, agora o negócio não tá mole não"; aí eu fiquei meio aperreado, fiquei meio aperreado! E a experiência que eu tinha acordado pra ir pra casa era tirar do rumo da ponta da árvore que ia pra lá, eu ia daqui pro pé, porque daqui do pé eu sabia orientar pra ir pra casa no escuro. Um sonho, e sabe que tava tudo dormindo, mas perigoso de bicho pegar a pessoa, a pessoa dormindo conversando nada sozinho no meio do mato, mas não vê que coisa, sim senhor; pois rapaz eu não sei como é que foi um sonho daquele não. E eu tive lá foi tempos, foi tempos mesmo, eu contei muita história, muita coisa; que eu era cheio de nove horas, contava muita anedota, muita história o tempo todo, e eu não tratava de ir lá pra casa de noite e sonhar. E meus sonhos sempre foram assim, sempre foi assim.

Quando eu era menino eu me lembro se sonhar mais com pesadelo, bicho atrás de me pegar. Um tempo uma onça vinha me pegar e eu tava encima de pau e ela assim pulando atrás de pegar nos meus pés, e eu sai voando assim numa altura de uns três metros, e ela por baixo atrás de pular pra mim pegar e eu voando, voando, eu sei que ante de eu cair eu me acordei, ela não chegou a me pegar. Eu era menino na idade de nove anos.

Esse não foi meu sonho mais antigo, não! Teve um também, lá nos pastorava passarinho em faixa de arroz grande, lá nós plantava muito, e tinha uma faixa de arroz muito grande assim e eu passava o dia batendo lata lá. E quando foi de noite eu fui sonhar, sonhei espantando passarinho de dentro dessa faixa de arroz; adipôis eu vim um indivíduo que o pessoal bota coisa em cabeça de menino negócio de Caipora, essas coisas, coisa que não existe, e aí fica amedrontado, e eu tô lá muito satisfeito quando lá vem essa tal de Caipora no sonho. A Caipora no sonho era um molequinho, um molequinho assim um menino de seis anos naquele tamanho, seis ou sete anos. $\mathrm{E}$ eu sei aí que ele falou comigo perguntando quem tava aí, eu olhando assim pensando que era outra coisa, eu digo "eu tô pastorando essa baixa de arroz até lá em casa", vai já me pegar, aí eu meti o pé na carreira, eu me meti o pé na carreira quando cheguei lá dentro faltou tato nas pernas e não tinha 
equilíbrio, com medo grande e eu não podia correr, aí eu cai quando eu cai ele chegou com um negócio jogando água nas minhas costas assim com um, esse negócio de salpicar água, furadinho assim. Aí eu me acordei quando essa água fria bateu nas minhas costas!Viu como a gente sonha besteira. Tava com uns oito anos mais ou menos

Essa semana eu sonhei. Esse foi meu último sonho! Foi lá no meu sítio mesmo, foi lá no meu sítio mesmo, eu fui lá e vi muito rastro de gado. A pegada do gado, onde o gado pisa fica aquele rastro! O gado via a minha partida e ficava lá, e eu vi muito rastro de gado, e vi uns cavalo velho magro, e vi bem uns 3 burros também. Eu digo "agora será que será que pra todo canto que eu vou esse homem bota esses animais pra cá, que eu já vim me mudar pra cá e esses animais tão aqui de novo, o que quê ele quer? Quê que eu mato”. Esse homem existe! Era um velho, um velho que tem lá chamado Mendonça, ele é goiano, ele era vizinho do meu lugar, eu assim do lado daqui pra lá, perto da balsa que cruza os carros pro Acre, faltando três quilômetros pra chegar lá, é assim meu lugar e o dele. Foi ele que tomou meu lugar! Comprou gado pra lá, mas coitado todos envenenados, e eu matei alguns, mas aí os meus cartuchos tava pouco, eu vim comprar 20 cartucho aqui, mas quando eu cheguei lá eu já cheguei ruim dessa perna, aí o jeito foi deixar lá pra ele roubar, e a espingarda e vim pra cá, quando eu cheguei aqui dia 19 de março, cortaram a perna. Esse foi o último sonho que eu tive. Mas já era outro canto não era o meu lugar, esse lugar assim era um lugar deserto, o lugar só tinha muito era árvore, árvore do mato mesmo no caminho, aí isso é assim, agora com o velhinho trançando arreio num burro magro, feio, um animal assim castanho, que nós chama assim mais amarelo.

Eu sonhei com minha mulher que deixei no nordeste uma vez em 1947, eu sonhei com ela viva, do jeitinho que nós vivia a convivência de casa, parecia dois meninos. Ela com 13 e eu com 19. Sonhei lá na colocação de seringa num lugar chamado Bom Futuro, e lá nós tava mais muito satisfeito e coisa e tal, só não vi ela grávida, do jeitinho que eu deixei ela, grávida não, ela ficou grávida. E o que é certo é que vinha comigo lá e conversava, e aquelas coisas e ela falando, e eu perguntei à ela, eu perguntando umas coisa eu digo "mas Maria me diga uma coisa, porque é que" no sonho, "porque é que agora tão mudando o nome do lugar, aqui, sabendo no sonho que eu tava no norte e ela tinha vindo pra aí, "porque é que tão mudando o nome do lugar do Ceará?", porque mudaram foi muito, mudaram muito. Aí ela tinha quintanista naquele tempo, era bem sabida ela, aí ela disse "bem Adálio, o negócio de mudar o nome é que eles querem agora adotar um sistema muito ruim tipo indígena, indígena é, agora não vai mudar assim nome como Quixadá, que usava né, guarani porque essas coisas não muda que já é né”, e assim ela deu uma porção de explicação, e eu vi ela perfeitazinha assim como tivesse viva, com o vestido que ela mais gostava de usar, um crepe chamado mangol, fino. E assim a gente sonha muita coisa e aí me acordei. $\mathrm{E}$ as explicação que eu tive dela só foi essa. 
Essa foi a única vez, a única vez que sonhei com ela. Primeiro acordado, que eu tava numa colocação, aí de, lá mesmo nesse mesmo lugar, eu tava numa colocação. Eu tinha chegado do corte naquela hora, do corte da seringa, ele saí 6 horas dali, eu não sai de noite, sai 6 horas da manhã, riscava a estrada toda quando é 11 horas chega em casa, esquenta a bóia, a comida dele, aí bebe água, faz um café, alguma coisa; aí sai colhendo de novo, quando é umas 4 horas tá em casa. Pois bem eu tinha chegado do corte 11 horas, aí veio uma pombinha branca e chegou, veio de lá pro rumo de casa e sentou no meu ombro, aí eu disse "essa bichinha tá com sede", aí eu peguei lá, eu tinha muito um vasilhame botei bem encima da mesa, botei e ela entortou, meteu o bico assim dentro, e ela só levanta o bico uma vez, não é como outro bicho que bebe com ganância, não, ela bota o bico e bebe tudo de uma vez, quando levantou deu uma voltinha por ali e foi se embora. Quando foi com esse outro dia que eu sonhei, quando foi no tempo que eu escrevi pra lá ela já tava morta, quer dizer que ela em vida me avisou, e eu de noite sonhei vindo avisar, já depois que ela morreu.

A pombinha veio e fez isso, aí quando eu sonhei com ela, que ela veio no meu lugar aí com poucos dias já veio a notícia que ela tinha morrido. Ela veio me avisar, numa casa que tá no meio da mata, uma casa pequena, acho que uma cabana, e ela veio e sentou no meu ombro, bem branquinha. Isso aí eu fiquei bem impressionado, porque eu tinha vontade de voltar, eu não queria mesmo era voltar pra lá, mas que eu voltava aqui, chegava com ela e trazia assim pra Belém, por aí assim né!? Agora Ceará eu não queria mais nada! A moça acabou morrendo fiquei aqui mesmo. pois é se deu isso, quando foi com uns dois dias eu tive esse sonho, que ela veio lá em casa.

Agora que aparência dá, aparência dá, como no tempo do exército eu sonhei que ia ser um soldado e deu mesmo, eu tive 8 dias no quartel, tive 8 dias no quartel, mas com aquele negócio que botaram aquele Afonso Pena a pique que ia pro o Rio de Janeiro cheio de família, mulher, homem, criança, tudo ali, e ele botou o submarino levantou nas águas da Bahia, entre Bahia e Rio de Janeiro né, e quando acaba mandou dizer pro comandante que ele podia retirar as famílias de dentro que ele ia torpedear o navio, aí o comandante ainda falou pra ele que não ia levando negócio merda de coisa de mantimento pra guerra não, que ali só ia gente mesmo, ele disse que não tem jeito não. Aí o pessoal se a retiraram todinho, ficaram nos estaleiro, era tanta gente que os estaleiros pouco, as mães que tinha filho segurava só no beiço do escalé pra dá um cantinho dentro pro filho. E assim mesmo o miserável depois passou uma rachada de metralhadora que escapou uns quatro e um jangadeiro, daqueles que pesca, que lá no Ceará pesca muito de jangada, foi o que andou catando algum levando pra contar a história. Agora isso não foi sonho meu, foi verdade mesmo. O que eu quero dizer que isso empatou de eu ser um soldado, porque eu já tava lá com oito dias, aí eu fiquei! A folha, digo, ali do jornal era um tostão, aquele gazeta de notícias do Ceará, de Fortaleza. E aí vendo uma notícia dessa aí eu digo "agora desmantelou todos os meus planos, se tiver outro canto pra eu ir pro exército é que eu não quero, de jeito nenhum!” Justamente o comandante disse logo “os recrutas 
que quiser ir por norte cortar seringa pode ir, que o Brasil também precisa muito é da borracha, precisa da borracha", aí eu só fui desviado, com oito dias que eu tava lá.

Durante a vida eu sonhei muito com mulher! agora até que não tem sonhado não, mas durante a vida sempre eu sonhava, agora que não sendo minha, mas eu vendo aquela pessoa que eu nunca via, falar comigo, me abraçar e prestar bem atenção, e perguntar pela minha família; assim tudo eu já vi no sonho. Agora de eu viver mesmo mais ela eu nunca sonhei não, eu nunca sonhei não! Agora eu sonho assim, vendo muitas mulheres, conhecidas, diz que é minha conhecida, pergunta por parente, e eu no sonho eu sei mesmo que ela vive porque ela fala em nome de pessoa que tem mesmo né?! Eu já sei que ela conhecia o meu povo mesmo no sonho. Mas o sonho é uma variedade, só a pessoa coordenar. O sonho é uma variedade, não tá coordenado, tem de tudo! Já sonhei também com água, açude, rio!

Com água eu sonhei muitas vezes, eu tava perto de um açude, que lá nós temos açude no Ceará nós tem açude, aí eu tava em cima de uma árvore que nós temos chamada Pitombeira, e eu assanhei umas caba, uns marimbondo que ferra a gente e dói! E eu fui tirar um cacho de pitomba e eles vieram pra cima de mim e eu pra me escapar me ajoelhei dentro d'água aí desci mesmo até não da pé, mas não cheguei a tocar na terra, aí eu mesmo no sonho imaginei que não dava de alcançar a terra e sair lá fora! Aí eu meti as mãos e os pés, fazendo movimento de nadar, tirando no rumo de cima, o rumo de cima, até que quando eu fui vendo o clarão do dia, no sonho, né?!!!

Eu tenho sonhado tomando banho no rio, tomando banho assim um pouco amedrontado, que no Amazonas aparece jacaré, cobra e pega a pessoa. Tenho sonhado com umas cobras, sempre eu sonho com uma cobra, mas num tempo desse eu sonhei me atolando lá num barco velho nesse Madeira que é um rio que tem cobra, e eu me atolei! E andava atrás de pegar um pau pra pisar em cima pra não pisar muito na lama, aí eu escorreguei e caí n’água e andei me batendo e aí já não foi banho aí foi por acaso, não foi banho não! E me bati, me bati e aquele nervoso medonho do bicho me pegar, parece que eu tava nervoso do bicho me pegar pelos pés, que aquela água é feroz, tem jacaré, tem cobra, Sucuri grande, eu matei cobra lá de doze metros. E assim eu me acordava aperreado, sonhava sempre assim sendo aperreado! E sonhei também um tempo, que eu fiz uma viagem com meu patrão num batelão, pra ir buscar mercadoria por água muito longe, que quando e não fui bem assucedido, o batelão se alagou em viagem, quando foi de noite eu sonhei do mesmo jeito. Sonhei que o batelão tinha se alagado e eu tava doido lá dentro d'água, mas tava dentro do meu quarto, não era nem na minha casa, era na casa do meu patrão. E eu dei uns grito e levantou gente de rede e me pegando no mocotó de gente, e dizendo o que é isso rapaz? Eu digo é pau na moleira que se eu não me segurar a água leva! "você tá doido é”; digo "doido não, ando atrás de 
escapar". Eu acho muita graça, acho graça demais quando lembro disso! Mesmo assim quando me acordei tava pegado nos dois.

Pois é foi o sonho maluco que eu tive, do jeito que nós andemos aperreado eu fui sonhar de noite assim. Como um sonho também, agora que eu me lembro o primeiro cinema que eu fui não tinha, era mudo, não tinha voz, não é como hoje, era mudo, ficava aquele negócio escrito lá, o que eles falava fica escrito lá, mas não tinha voz nenhuma. Agora vinha aqueles trem assim e eu tava mesmo bem perto da tela, de onde que eu tava pra passar a fita era bem perto, foi a primeira vez que eu fui ao cinema; aí quando vinha aqueles trem assim que vinha que vinha, eu achava que ele vinha pra cima de nós e eu fui ficando invocado, e de noite eu sonhei. Quando lá se vem, o trem embocou de trás já embolando e eu caindo da cadeira, e já me levantei da rede e saí lá por dentro do quarto nos escuros, aí o meu pai gritou "que negócio é esse aí menino, peraí que eu vou já dá umas lapadas nesse sem vergonha"; aí eu me acordei com a voz dele, ele gritou muito alto! mas era peitando cadeira, derrubando tudo, que eu tava com medo que o trem viesse pra cima de mim!

Nunca sonhei com terra, agora com mato, mata, árvore eu sonhei! Sempre eu sonho dentro da mata, porque minha mocidade aqui no Amazonas toda vida foi assim, sempre eu sonhei dentro de mato, e eu sonho demais! Sonho na mata, aquela mata assim bonita e eu ali por dentro, vendo as coisas. E eu achava muito bom, aí me sento naquele pau, aí tem árvore medonha que tem raiz em cima da terra que fica dessa altura estendida assim, e eu sento ali, num sonho fumando cigarro, nesse tempo eu fumava, eu sonho fumando aquele cigarro muito satisfeito. Também nunca sonhei com fogo, não lembro de ter sonhado com fogo, nem com o ar, nem com o vento. Nem com temporal, apesar de lá onde eu morava dava temporal que nós saímos lá na rua pra olhar, mas não sonhei não. Posso até ter sonhado, mas não me lembro.

Agora o sonho, o sonho pra mim é uma espécie de uma ilusão assim, algum que dá certo, mas isso é raro, agora tem algum que é vidente mesmo dá certo, mas a maior parte é ilusão, porque a gente sonha com uma pessoa que nunca viu ele, eu tenho sonhado é muito, falando ainda, dando a mão pra uma pessoa que nunca eu vi. Quer dizer que ali deu fora, agora tem muitos que o camarada sonha e vê. Eu quero dizer que o sonho é uma variedade, é uma coisa assim, muitos dizem que é o que o sujeito imagina de dia, mas isso aí não é certo, não é certo não, o sonho ele vem na gente assim aproveitando porque o sujeito que tá dormindo não é como tá acordado. Porque ele dormindo tá quase como morto, ali tá, arquejando, tá respirando pra não morrer porque se parar morre, mas aí acontecem muitos sonhos, e é por isso que ele é uma variedade é uma coisa assim, mas pensar o sonho não é, alguns que dá certo conforme a gente imagina às vezes uma coisa, aí pode ser que aconteça certo. Tem diferença entre pensamento e sonho! O pensamento é mais positivo, é mais positivo porque quando a gente bota o pensamento assim numa coisa é porque ou o 
sujeito tá cismando ou tem quer ter isso né? Já o sonho acontece sem nenhuma dessas idéias. Agora o pensamento o camarada bota num sentido uma coisa ou que interessa a gente ou que não interessa, ou que às vezes ache bom vim pro lado da gente ou que ache ruim, aí a gente tem aquele pensamento. Mas isso aí é uma mudança, como se diz é mais positivo do que o sonho, porque pode até às vezes ser acordado! O pensamento é mais legal! Mas a gente quando bota o pensamento assim nunca coisa às vezes o sujeito tá imaginando o que é que pode a vida dar ou que pode acontecer fazendo isso ou fazendo aquilo. E assim o pensamento vai levando pra algum lugar! ${ }^{110}$

Quando penso no sonho mais importante da minha vida foi ver a minha mulher quando ela já tava morta e veio me visitar num sonho, eu morando sozinho no meio da mata. Pra mim foi o sonho mais importante porque eu vi ela perfeitamente, e tivemos lá juntos, mais de uma hora de bate papo, e eu né?! ${ }^{111}$ Eu fiz muita pergunta a ela e tudo que eu perguntei ela respondeu. Agora que eu perguntei por uns parentes que eu tinha lá e ela não deu notícia. Ela tava vestida com aquele mangol, é um crepe assim que é meio cor de rosa, era cor de rosa ele mesmo! E com o mesmo sapato que ela tinha se casado comigo, com o mesmo sapato! E eu perguntei muita coisa a ela assim. Agora aqui com relação a esse negócio amor nada, foi só mesmo uma palestra, foi só uma palestra. E eu perguntei muita coisa a ela, e sempre que eu perguntava ela dava saída, até que eu perguntei esse negócio dessa mudança, porque depois que eu tô aqui lá pra fora tem muito lugar que eu não sei mais como é o nome, é tudo é mudado, e ela disse que ia ficar tudo com nome indígena. Ela era quintanista, naquele tempo os estudos eram mais aprofundados, hoje em dia não se faz isso mas naquele tempo fazia, porque hoje é magistério, naquele tempo é formação de pessoal. O estudo era mais aprofundado! a pessoa levava mais livro pra escola, e tudo isso, e hoje em dia não! Naquele tempo uma pessoa pra fazer assim um terceiro ano, aí já tô começando de novo, tô contando de novo! Dizendo que fazer assim um terceiro ano o sujeito tinha que ter uma geografia, uma história do Brasil, uma aritmética, uma gramática, e livro assim que desenvolvia muita caligrafia, livro grande com a palavra manuscrita, e ensina a capacidade, prática comercial e tudo isso. E tudo isso tinha que lembrar pra fazer o exame de admissão, assim no terceiro ano como eu fiz, aí você tem que saber um pouco de aritmética, que é a matemática comercial e saber a tratar as capacidade e tudo! Que pode tratar mesmo, um dia pode até ser que a gente se refere ao um Presidente, naquele tempo era sua excelência, hoje em dia tá tudo mudado, o Papa é sua Santidade, e vinha registrado no livrinho. E assim ensinava a fazer uma carta familiar e comercial também, que a carta comercial é mais difícil que a familiar.

Agora eu, assim com igreja é muito difícil eu sonhar, agora que antes de eu me casar eu sonhei com uma pessoa muito jovem assim, muito nova; antes de eu me casar, eu tava com 17 anos nesse tempo e eu sonhei com ela pegada no meu braço e assim umas assas como se fosse um anjo, e 
ela toda vestida de branco, e eu tava satisfeito com aquele sonho, eu digo "engraçado que eu não sou perdido em religião, e vindo coisa estranha pra mim"; e eu fiquei muito animado com aquele sonho. E o que é certo é que me acordei e nada, se acabou em nada, e logo aconteceu o casamento. Foi o sonho que eu tive com religião foi esse. Agora eu, também aí eu não sei que às vezes a gente vê uma coisa impressiona e sonha, porque lá antes de eu conhecer minha mulher, eu não sabia nem quem era ela. E era ela e outra moça, lá naquela festa de igreja coroando Nossa Senhora! Cantando aquela cantina “o minha Mãe aceite essa coroa”, ela, minha mulher, de um lado e a outra do outro, e eu fiquei conhecedor. Essa foi à primeira vez que eu vi minha mulher e aí sonhei com um anjo e depois casei com ela! Ela era um anjo, era um anjo mesmo, tinha asa, aquelas asonas. Porque aqui fazem festa de igreja assim, eu já vi ali em Abunã fazem uma asinha pequena, lá, no nordeste faz uma azona grande, com uma pessoa bem vestida, parece um anjo mesmo. Agora no sonho o anjo não me disse nada não! Era só pegado no meu braço e eu passeado mais ela pra aqui e pra acolá. O anjo tinha rosto era de uma pessoa mesmo, de uma menina muito jovem, 13 anos por aí assim. Era rosto de mulher. 


\section{A MÚSICA}

\section{"Quando a gente faz poesia se sente satisfeito porque desabafa o peito..."}

Quando eu compus essa música “ a História de um Nordestino na Amazônia” eu já estava aqui. Foi quando eu soube que a minha mulher morreu, mas eu fiquei assim, com uns 10 anos foi que eu vim fazer, que eu compus. Toda noite depois de largar do trabalho, fazia uma rima de 4 versos e na outra ajeita e na outra sai outro verso e aí quando dá fé tá completa a música! É porque a gente vai arrumando selinho, a gente faz aquele verso e sabe aonde deixou, no outro dia pega dali prá frente e vai! Tudo na cabeça aí quando é na outra noite faz outra parte até que a gente vê que já dá pra terminar, já tá muito comprido. Fica tudo na cabeça, nunca passei pro papel! É decorado mesmo na cabeça! Feito na cabeça assim quando larga do trabalho, quando acaba de jantar, já tomou banho, aí nós vai rimando em seis linhas. A gente vai vendo os assuntos das passagens que se deu, que aí tudo é exato.É uma história enversada! É assim que eu faço a rima: a gente bota num sentido como se deu desde o dia que eu pedi a moça em casamento, aí vai ajeitando, ajeitando! Faz o primeiro verso e daí pra frente vai se fazendo até quando termina tudo! Quando a gente vê já dá uma música. ${ }^{111}$

Eu comecei a tocar violão tava com 18 anos. Porque no tempo de meu pai não tinha liberdade pra isso, ele era um pouco duro não deixava ir para essas coisas, mas ele já tinha falecido e eu tava lá cantando com um tal de Jaraguaia ou Jaraguai, eu não sei mais, e ele estava perdendo pra mim no martelo ${ }^{112}$. Tinha muita gente assistindo e só, me aplaudiam! Aí ele puxou uma faca e queria furar um sujeito muito importante que tinha lá, Francisco Olino. E eu como de menor eu digo: “eu nunca mais pego em viola" meter numa briga desse jeito, Ave Maria! E nunca mais fiz martelo.

Todo rapaz novo gosta de serenata e eu fazia aquelas serenatas! Cantando aquelas valsas bonitas! Lá no Ceará, por exemplo, a serenata é muito usada, a gente saia onze horas da noite e ficava até uma hora da madrugada cantando. A gente sai fora da cidade cantando! Eu tocava violão, mas tinha pandeiro dos outros, e tinha cavaquinho e tamborim e um clarinete e assim que nós tudo saía de noite! Eu morava na casa de minha mãe, ainda, que já era viúva, agora os outros morava em república. Aluga uma casa para 4 rapazes, assim da para pagar numa coleta e sai mais barato. E saía em grupo pra fazer serenata até uma hora da madrugada quando a gente voltava pra casa!

Eu já fiz outras músicas. Eu tenho uma músicazinha que eu fiz pro Lula, eu torcia por ele, eu vou cantar ela. Lá vai: 


\section{MÚSICA PARA O LULA}

Lula é um pernambucano

Que honra a fidelidade

Respeita aquele ou aquela

Seja qual for sua idade ${ }^{113 a}$

Com Lula não tem pequeno

Ele ama de verdade.

Lula levou duas quedas

Nada sofreu felizmente

Com a força renovada

Levantou-se novamente

Dizendo assim para o povo:

"Maroto eu sou Presidente".

Com Lula na presidência

O Brasil tá governado

Chega fartura de tudo

Pro povo não falta nada

Educação se eleva

E a doença é controlada.

E o brasileiro

Hoje em dia vive alegre

certamente

Porque Lula com certeza

Vai ser nosso presidente

A coisa vai melhorar

Eu digo antecipadamente.

Quem vota em Lula deseja

Vê um Brasil mais seguro

Não quer ver tantas pessoa 
Passar fome no futuro ${ }^{113 \mathrm{~b}}$

Porque no presente o pobre

Ta comendo um galo novo.

O Brasil tá com dívida externa

Inflação e carestia

Doente e pobre com fome tem tanto que disse um dia Seqüestrador seqüestrando

Ladrão rouba todo dia. ${ }^{113 c}$

Além disso no Brasil

Tem muito pobre escravizado

Rico é sujeito à seqüestro

O resto é discriminado

Esses pobres é mal

Com Lula vão ser só

Lula é homem traquejado

Honesto e hospitaleiro

Não mancha reputação $113 \mathrm{e}$

Desse país brasileiro

Vote em Lula porque ele

Desse povo é companheiro

Para o povo brasileiro

A coisa boa não tá

Se não houver uma mudança

O que vai dar resultado

O pobre vive migrando

Pra ali, pra aqui, pra acolá

Portanto quando ir votar

Faça assim desta maneira

Vote em Lula 
Porque ele é da classe hospitaleira

E pode trazer de volta

Pra nós a vida fagueira

Essa vida Brasileira

Foi construída no mato

Lá tem muito gabiru

Mas Lula vai criar gato

Na sede do Parlamento

Pra acabar com tanto rato

Eu vou em 98

Votar com toda certeza

Em Luís Inácio da Silva

Digo com muita franqueza

Fazendo assim to lutando

Em prol de nossa grandeza.

Lula tem muita presteza

Nele está nossa esperança

Pois se ele for eleito

Vamos ver com segurança,

O Brasil dá a volta por cima

E pra melhor vai ter mudança

Com Lula não tem lambança

Pois ele diz e garante

Se eleito presidente

Nosso futuro é brilhante

O Brasil se desamarra

Ninguém segura o Gigante.

O que eu acho alarmante

É os preços reajustados

A carestia subindo

Em um ritmo acelerado

O pau só quebra no lombo 
Do pobre descamisado

Nosso país tem lutado

Porém nunca foi capaz

De pagar a dívida externa

Por isso fomos pra trás

Paga juro todo ano

A conta é crescendo mais.

Lula tem todos os sinais

Do homem que tem traquejo

Quando ele assumir o cargo

Faz lá o seu remanejo

O Brasil só vai pra frente

E deixa de ser caranguejo. ${ }^{113 \mathrm{f}}$

Se somente o meu desejo

É ver o Brasil bem cuidado

No dia da eleição

O eleitor segurado

$\mathrm{Na}$ caneta escrever LULA

E o resto é papo furado. ${ }^{113}$

Essa foi pra segunda eleição dele. Fiz essa música para o Lula porque é um homem muito trabalhador, eu sei que ele seria um bom governante porque ele é um pernambucano! É um homem trabalhador! Ele não tem egoísmo! Se ele não ser pela pobreza, outro é que não é! Porque ele ta sabendo como é a vida de um pobre, porque ele já foi pobre também! E esse pessoal que nasce no grandão, eles não sabe o que é sofrimento, não sabe o que é dinheiro pouco, tudo quanto falta já vai buscar porque tem posse. E o pobre as vez faz um plano e diz talvez daqui uns 3 dias possa adquirir isso pra casa, mas que por hora ele volta pra senhora dele assim e diz logo pra veia dele e diz: "minha velha venha, tenha paciência que hoje não dá". E assim eu acho que eu votando no Lula é uma coisa muito legal! E ele sabe o que é a vida de um pobre e sabe o que é a vida de um rico, sabe o que é a vida de um pequeno e a vida de um grande! Porque hoje em dia ele é um grande! O Lula é um grande homem! Basta ser Pernambucano! 
Quando a gente faz poesia se sente satisfeito porque desabafa o peito ${ }^{114}$ e tem idéia por aquele sistema de rimar e quando a gente completa assim verso e já sabe que tá a gente fica mais animado, sabendo que é capaz de fazer versinhos e enversar uma história seja ela qual for e isso aí é a satisfação de quem faz a música. Agora tocar hoje é mais difícil por causa das minha mão, da doença! ${ }^{115}$ Aí o violão já não deu mais! $O$ violão assim naquelas posições que a gente faz, tem primeiro DÓ, RÉ, MI, FÁ, SÓ, LÁ ficou mais no tempo que minha mão era legal! Na idade de 20 e poucos anos até 30, ainda dava de eu fazer muita coisa boa, mas com o trabalho a gente deixa o que sabe para cuidar da obrigação do serviço pesado e eu deixei pra cortar seringa. Abandonei o violão!

As minha mão foram ficando assim com dificuldade de movimento, em 68, 70. Aí me senti agravado desse mal, por aí! Mas ele veio de uma forma meio traiçoeira, não veio com mancha, veio como uma dormência! ${ }^{116} \mathrm{E}$ aí eu não posso fazer uma nota, a mão emperra, só dá o baque, só faço mesmo bater toadas dos repentista! Porque não dá pra fazer nota. Mas no tempo que eu fazia as notas, eu fazia uma porção de notas, mesmo porque cada nota tem 4 posições, tem os acordes, tem os bemou, tem os relativo. E até que o sujeito faz nota que não precisa, porque a música ela é igualmente assim ao nosso alfabeto, a pessoa que estuda, estuda, mas no fim nunca chega, é como a música. Aqui no pescoço do violão, aqui pra cima, no braço, ainda tem posição pro sujeito fazer fusa e semi fusa, colchete e semi colchete, mas que disso aí não é preciso nunca, porque muito antes de chegar aí, já sobrou o que sabe e é assim não precisa aprender tanto! É igual como a gente diz, um milhão, bilhão, trilhão, quadrilhão, quinquilhão, sexquilhão, daí pra frente ninguém vai mais, é justamente assim, a mesma coisa. Aí não precisa, como é essa que eu falei de fusa e semi fusa, colchete e semi colchete! Ninguém chega lá não, mas se no método tem, a gente vai, tem a mão boa, sadia, vai fazendo!

Quando eu comecei a ficar doente as pessoas não cismavam e nem eu também. Eu já tinha sido atacado por uma cobra, uma jararaca, eu não pensava numa doença dessa, porque na minha família todo mundo era limpo, eu não pensava de sofrer uma dessa nunca! E o pessoal não desconfiava e nem eu, porque não tinha mancha, ela veio só com dormência, atacou com dormência, aí foi atacando, e se manifestando! Quando eu me vi perdido mesmo que, digo "agora, lutando dentro d'água, andando por dentro dos mato eu ficar com as perna fraca!" Aí eu vim pra cá em abril de 1978, e saí em janeiro de 79. Então pra mim mesmo ninguém dizia nada, porque se tivesse um consciente que tivesse avisado com tempo eu tinha vindo mais cedo, porque eles são muito cismado daqueles que saí aquelas manchas feia pela cara, nos braços, aí a pessoa vê e já fica cismado, e em mim não saíram essas coisas.

Meus amigos, eles vinham ainda me trazer pra botar no hospital São José porque eu arrumei as passagens. Naquele tempo eu arrumei com um sargento, ele já morreu no Acre, Sargento 
Eduardo, do Exército, ele me deu 2 passagens que era pra eu vim e voltar, que ainda tava sob suspeita a doença, ia me botar lá no São José. Agora lá no São José foi que me chamaram pra lá, fizeram umas coisas, aí me mandaram para o Oswaldo Cruz. Meus amigos me ajudaram sempre, mas eu nunca parei de trabalhar, não precisava deles. Eu já tinha as passagens pra vim, aí quem se interveio foi o Procurador da Vila de Abunã, um homem chamado Otacílio, um mineiro, ele hoje em dia tá no 42, onde chamam Vista Alegre, no caminho do Acre. Ele já foi até prefeito de lá. Aí ele entrou na frente, ele entrou na frente e eu só fiquei no hospital porque ele entrou na frente, e quando acaba foi dizer pro Doutor Jadir que eu não tinha condição de voltar.Mas o Jadir me cortou aqui na orelha, e aqui no joelho, apertou e aqui no cotovelo aqui assim, aí disse "não, esse homem aí é pra se tratar em casa, não precisava ficar aqui não". Se eu tivesse me tratado em casa, eu era capaz de ter recuperado, pra ficar bom de novo, mas fiquei aqui. Fiquei porque ele foi dizer pro Doutor Jadir que eu não tinha condição pra voltar. Disse isso de ruim porque eu tinha meu sítio, muita plantação, muita macaxeira, muita galinha, carneiro, ovelha, tudo eu tinha lá. E ele queria ficar com o meu sítio com certeza, mas não teve jeito não, eu fiquei! ${ }^{117}$ O Sargento que tinha me dado ajuda pensava que eu vinha e voltava, arrumou aquela passaginha que o governo dá! Aquela que chama de passagem de cortesia. E já me deu duas porque sabia que eu vinha e voltava. E esse outro agora foi dizer pro Doutor que eu não tinha condição de voltar, porque ele tava de olho comprido no meu lugar, mas ele não pode arrumar coisa nenhuma.

A minha família era limpa, era uma família onde todos são sadio, são sadio, nunca houve doença nenhuma no pessoal. O tempo que eu convivi com o meu pessoal, assim perto de 20 anos eu nunca vi uma pessoa nenhum tumor. O corpo limpo, sadio e quando não é limpo quer dizer que é doente. Tem o doente e o limpo! Eu quero dizer com isso que são um povo limpo, são uma gentona, bem branca. Eu era branco e corado, era branco e corado, agora hoje em dia eu tô desse jeito encardido. ${ }^{118}$ Porque a pílula, que tá até o nome dela aí debaixo do ventilador tava até o nome dela, aí a gente toma e ela encarde a pele da gente, só encarde a pele, é a Clorazemina, a Dopisona nem tanto, mas essa outra aqui que escurece a pele, antigamente chamavam ela lampreia, e ela encarde, mas eu era branco e corado, branco e corado. Em todo documento que eu tirava era branco sangüíneo, muito corado, quando eu tava no Ceará o pessoal andava um tempo, tinha um dentista, lá pra lá perto da nossa casa chamado Dr. Portela, o nome dele é Portela, agora o resto eu não sei, eu sei que era Doutor, no tempo era dentista prático, disse que era preciso uma sangria pra diminuir o sangue que depois que atacasse muito começava a perder o sono, mas eu sou cismado dessas coisas demais, aí na hora que eu fui fazer o exame de sangue furaram aqui, eu botei a mão na cara pra não ver! Não eu não gosto não de fazer exame de sangue. Mas sempre tem que tirar, tirar exame de sangue tá lá, não sei do resultado. E o que é certo é assim. 
A PALAVRA CANTADA

\section{HISTÓRIA DE UM NORDESTINO NA AMAZÔNIA}

Ao senhor dono da casa

Peço autorização

Para contar-lhe uma história

No seu honrado salão

Para esse povo presente

Vai a minha saudação. ${ }^{1}$

Não é poema nem lira

São rimas que a gente acha

Para inversar uma história

Que dito meu peito racha,

É a magoa de um viúvo,

Ex-soldado da borracha. ${ }^{2}$

E eu nasci no Ceará

E lá mesmo fui criado,

Tinha pai e tinha mãe

Por isso era bem cuidado,

Naquela terra querida

Eu amei e fui amado. ${ }^{3}$

Já com dezenove anos

Pra mim tudo tava bem,

Cantava nas serenatas,

Vivia no vai e vem,

Tinha xodó com mulher,

Eu não era de ninguém. ${ }^{4}$

Namorei lá uma moça

Quem eu dei meu coração 
Comigo ela fez o mesmo

Satisfazendo a paixão

Daquele que nessa hora

Pretendia a sua mão. ${ }^{5}$

- Querida eu vou lhe falar

Um assunto muito importante

Se tu quer casar comigo

Me responda nesse instante

Se me quiser sei que sou

O mais feliz dos amantes. ${ }^{6}$

- Me desculpa senhorita

Se eu tiver falando a toa

Pois sou um ser pequenino

Não mereço gente boa

Mas eu aguardo a resposta

Da excelente pessoa.

"Você é um rapaz novo

Não se julgue baixo assim

É de boa qualidade

Nunca fez papel ruim

Tem competência demais

E pra tomar conta de mim". ${ }^{7}$

"Peça ao meu pai e a mamãe

Faça isso sem demora

Eu aceito satisfeita

Tô muito feliz agora

Tu és um anjo adorado

Que no peito dela mora". ${ }^{8}$

Eu conheci que a moça

Tava louca de paixão

Para resolver seu problema 
Achei essa solução

Era o nosso casamento

Antecipa a previsão.

Fui logo pedir a moça

Num dia de terça-feira

Tava um clima temperado

Naquela tarde fagueira

Lá na casa do pai dela

Eu falei desta maneira: ${ }^{10}$

- Cidadão dono da casa

Desculpe o atrevimento

Eu não vim the visitar

Quero só nesse momento

Saber se o senhor me dá

Sua filha em casamento? ${ }^{11}$

- Da excelentíssima senhora

Também quero opinião

Se aceita o casamento

Me diga se quer ou não

Se aceitar os senhores

Não mancha a reputação. ${ }^{12}$

- Sou solteiro não tenho vício

Meu sistema é singular

Tenho casa, cama e mesa

E muito amor para dar

A ela quando vier

Tomar conta do meu lar. ${ }^{13}$

Nessa mesma ocasião

Pela filha o pai chamou

“Quer casar com esse moço?”,14

Em seguida perguntou. 
Ela disse que queria

Mas a mãe dela falou:

"Com beleza e mocidade

Ela disse - eu não me iludo

Mas um rapaz desse jeito

$\mathrm{Na}$ nossa casa tem tudo

Anda limpo e bem calçado

Também não é cabeludo. ${ }^{15}$

Eu aceito o casamento,

Mas não me bota em perigo

Minha filha é estimada". Disse o velho:

"Olha o que eu digo

Trate dela como eu trato

Se tu quer ser meu amigo". ${ }^{16}$

- Eu não prometo riqueza

Porque não sou potentado

Mas eu garanto ao senhor

Que depois de nós casado

Vamos ser um pelo outro

Dentro de um lar invejado. ${ }^{17}$

O pai e a mãe da moça

Concordou com o meu desejo

Fiquei tão feliz na vida

Que aproveitei o ensejo

Eu apertei a mão dela

E na testa joguei um beijo. ${ }^{18}$

Na hora da minha saída

A noiva tava na janela

Eu abracei o seu pai

Me despedi da mãe dela

$\mathrm{Na}$ noiva eu dei um abraço 
De arrebentar a costela. ${ }^{19}$

E depois o pai dela disse:

"Adálio eu vou te avisar

Quero ver seu casamento

Cedo se realizar

Noivo que faz corpo mole

É porque não quer casar". ${ }^{20}$

Choveu grosso em meu roçado

Com esse assunto fiel

O sogro tá me ajudando

Desempenhar o papel

Conforme o que ele me disse

A sopa caiu no mel. ${ }^{21}$

Já com dezenove anos

Eu tava na flor da idade

Minha noiva tinha treze

Era muita mocidade

Por isso eu tinha o desejo

De fechar nossa amizade. ${ }^{22}$

Eu fui falar com o padre

Pra fazer meu casamento

E dentro de poucos dias

Deu-se o acontecimento

No altar perante Deus

Recebi o sacramento. ${ }^{23}$

A noiva pegou uma aliança

Redondinha e amarela

Colocou uma no meu dedo

Pus outra no dedo dela

Nessa mesma ocasião

Novamente eu beijei ela. ${ }^{24}$ 
Ela vestida de noiva

Com a Santa parecia

Cheirosa como uma flor

Me abraçando dizia:

“Adálio agora é só meu!"

Lá eu chorei de alegria. ${ }^{25}$

Depois do nosso banquete

Pra noiva deram um troféu

Duas fotos coloridas

Colocadas num painel

Daí fumo para casa

Passar a lua de mel. ${ }^{26}$

E uma passagem como esta

Por mim nunca é esquecida

Pois eu matei o desejo

Maior que tinha na vida

Passei a noite abraçado

Beijando a mulher querida. ${ }^{27}$

Quando ela ficou grávida

Foi o meu maior prazer

Delirei de alegria

Porque desejava ver

O fruto de um amor puro

Naquela casa nascer. ${ }^{28}$

Porém a coisa mudou

E eu não tive a satisfação

De ver o meu filho nascer

Por causa do alemão

Que desfechou uma guerra

Mundial sem precisão. ${ }^{30}$ 
Fui chamado pra servir

O Exército Brasileiro

Tive uma tristeza imensa

Pois me disse um companheiro

Que eu ia diretamente

Pra guerra nos estrangeiro. ${ }^{31}$

Pra defender minha pátria

Eu não faço cara feia

Mas pra lutar longe dela

Qualquer um filho receia

Não acho conveniente

Se brigar nas terras alheias. ${ }^{32}$

Depois disso uns oito dias

Lá só se falava em morte

Quando um comandante disse:

"Os recrutas tão de sorte

Vão pra guerra da borracha

Riscar seringa do Norte". 33

Eu tive muita alegria

E achei maravilhoso

Me defender de uma luta

Pois o caso é tenebroso

Quem diz que vai para guerra

Satisfeito é mentiroso. ${ }^{34}$

Me alistei pro Amazonas

Porém antes da partida

Me abençoou chorando

Minha mãezinha querida

Disse: “Adálio eu rogo a Deus

Pra tu ser feliz na vida". 35

Minha tia me abraçou 
Chorando me deu um beijo

E disse: "Adálio faz coisas

Que é contra meu desejo

Sair assim pra tão longe

Será que ainda eu lhe vejo?" 36

Também com muita tristeza

Me despedi dos irmãos

Dos que tavam ali presentes

De tudo apertei a mão

Nenhum tava satisfeito

Com esta separação. ${ }^{37}$

A minha esposa tava

Muito grávida e comovida

Chorava feito uma louca

Lastimando a sua vida

Dizendo: “Adálio eu não posso

ta presente na partida". ${ }^{38}$

“Adálio preste atenção

To com seis mês de casada

Durante todo esse tempo

Tu não me faltou com nada

Hoje me deixa na saudade

Meu Deus que sorte malvada!" 39

Chorando perto do carro

Do povo eu me despedia

Com muita pena e tristeza

De longe eu falei: "Maria

Fique com Deus minha amada 
Já me vou até um dia”, ${ }^{40}$

Que saudade eu tenho de Aurora

Minha cidade natal

Do meu Ceará querido

Lá deixei meu natural

Pra defender certamente

O torrão nacional. ${ }^{41}$

Saí livre do Nordeste

Pra ser escravo no Norte

Minha vinda nessa terra

Foi uma falha na sorte

Não troquei égua por besta

Dei a vida pela morte. ${ }^{42}$

Quando cheguei no Amazonas

Fui logo num barracão

Lá comprei mil tigelinha

Bacia, balde e facão

Faca, machado, espingarda

Saco e uma aviação. ${ }^{43}$

Lá comprei panela e prato

Colher grande e colherinha

Depois comprei uma concha

Porque nada eu num tinha

E disso tudo precisa

Pra se lutar na cozinha. ${ }^{44}$

Quando foi riscar seringa

Tava um pouco endividado

Devendo para o patrão

Tudo que eu tinha comprado 
imaginando nessa conta

Passava a noite acordado. ${ }^{45}$

Ouvindo esturro da onça

Com muito medo eu saia

Para riscar minha estrada

Assim cortava e colhia

Com medo de andar de noite

No meio da mata eu corria. ${ }^{46}$

Quando o paludismo ataca

Retira a força da gente

Ali se treme uma hora

Sofrendo amargosamente

Para não morrer de fome

Lá eu trabalhei doente. ${ }^{47}$

E com respeito a comida

Não sabia fazer nada

Quando eu chegava da luta

Sentia as perna cansada,

Pois só comia farinha

Com açúcar ou carne assada. ${ }^{48}$

Sofrendo assim desse jeito

Me adaptei no lugar

Depois comprava o feijão

Botava pra cozinhar

Fritava carne de caça

Tinha café pra tomar. ${ }^{49}$

Com dois anos eu paguei a conta

Ao meu patrão companheiro

Ainda tirei um saldo

Lá de cinco mil cruzeiro 
Pra voltar pra minha terra

Eu achei pouco dinheiro. ${ }^{\mathbf{5 0}}$

Escrevi pra minha esposa

Pra saber como ela ia

Também mandei perguntar

Como é que se sentia

Morando naquela casa

Sem a minha companhia. ${ }^{51}$

E sobre minha pessoa

Já vivo impressionado

Sonho com você toda noite

Dando amor e sendo amado

Quando acordo num te vejo

Fico um pouco amargurado. ${ }^{\mathbf{5 2}}$

Sem ter você do meu lado

Não posso me acostumar

Sinto falta do meu bem

$\mathrm{E}$ das coisas do meu lugar

Daquelas praias de areia

E das águas verdes do mar. ${ }^{53}$

De viver sozinho no mato

Já tô ficando indisposto

Sem ter notícia de casa

Da vida perdi o gosto

Manda me dizer querida

Se o meu filho é vivo ou morto. ${ }^{54}$

Tô longe da minha terra

Mas tenho muita vontade

De voltar pra lá de novo

Com a força da mocidade

E abraçar novamente 
Para matar a saudade. ${ }^{58}$

Desde que cheguei no Norte

A minha luta é pesada

Vou dormir tarde da noite

Acordo de madrugada

Pensando em quem tá tão longe

Minha alma apaixonada. ${ }^{59}$

Você ficou no Nordeste

Mas não sai do meu sentido

De você tenho saudade

E também do filho querido

De eu ter vindo para o norte

Já tô muito arrependido. ${ }^{60}$

De longe é que a gente sabe

Que falta faz a pessoa

Porque a saudade dela

No peito se amontoa

Muitas vez num ta doendo

Chega a lembrança magoa. ${ }^{61}$

Pode aguardar meu retorno

Nosso amor não se destrói

De noite sonho nós dois

Abraçado feito um moio

Ainda acordo no jeito

Uma coisa dessa dói. ${ }^{62}$

Pra não ficar enfadonho

Esse assunto carinhoso

Termina a carta dizendo

Que tô muito desejoso

Pra ti dar mulher querida

Um abraço afetuoso. ${ }^{63}$ 
Quando a carta chegou lá

Veio uma resposta penosa

A sogra escreveu dizendo

Ainda muito chorosa:

"Noticio com pesar

A tua esposa é saudosa". ${ }^{64}$

"Com três mês que tu saiu

A sua filha nasceu

Com cinco mês de idade

Não teve sorte morreu

Com um ano e quatro meses

A mãe dela faleceu". ${ }^{65}$

E antes dela suspirar

Muito queixosa falou:

"Não sei o por qual motivo

Adálio me desprezou

Quero saber mas não posso"

Chorando ela suspirou. ${ }^{66}$

Eu dei graças a Deus não ver

A morte desta criatura

Pois se eu tivesse presente

Uma taça de amargura

Eu bebia quando ela

Saísse pra sepultura. ${ }^{67}$

Falei pra meus camaradas:

"A minha esposa morreu

Mas deixou marcas profundas

Nesse peito que era seu

Pela beleza que tinha

E o amor que ela me deu". ${ }^{68}$ 
Recebi as condolências

Desse povo valioso

Expressando o seu pesar

Isso eu achava penoso

Recebia com tristeza

Pois eu tava pesaroso. ${ }^{69}$

E agora eu peço à Deus

Que me dê a condição

Para resistir um golpe

Que feriu meu coração

Só mesmo um pai poderoso

Me dá resignação. ${ }^{70}$

Hoje em dia sou viúvo

Minha sorte foi ingrata

Quando eu me alembro dela

Sinto dor que me maltrata

Saudade não é doença

Mas dentro do peito mata. ${ }^{71}$

Dizem que homem não chora

Mas isso não é verdade

Quando a minha esposa morreu

Eu chorei sem ter vontade

$\mathrm{O}$ vivo chorando prova

Que o morto deixou saudade. ${ }^{72}$

Eu desfrutei muito pouco

Essa vida conjugal

Agora faço um pedido

Ao Pai Celestial

Pra não esquecer da finada

E nunca eu ser marginal. ${ }^{73}$ 
Todo dia peço à Deus

Que dê a mulher saudosa

Um cantinho pra descansar

Perto da Mãe Poderosa

Para receber da Santa

Uma benção copiosa. ${ }^{74}$

Lembranças da minha esposa

Levo para eternidade

Dela eu não esqueço nunca

Porque lhe tinha amizade

Pois só quem ama é quem sabe

Quanto custa uma saudade. ${ }^{75}$

Pra esse povo presente

Vai o meu muito obrigado

Bater viola cantando

É um remédio indicado

Pra tirar magoa do peito

De um viúvo apaixonado. ${ }^{76}$ 


\section{PARTE III}

A PALAVRA CONTADA E A PALAVRA CANTADA: UMA LEITURA 


\title{
UMA LEITURA POSSÍVEL
}

\section{"Cada homem é uma humanidade, uma história universal..."}

Jules Michelet

\begin{abstract}
ABERTURA
Parafraseando Barthes no seu trabalho sobre Michelet (1991), “o leitor não encontrará neste trabalho nem uma história do pensamento de Michelet [de Adálio], nem uma história de sua vida, e muito menos uma explicação de uma pela outra. (...) Mas procuro uma temática, ou melhor ainda: uma rede organizada de obsessões."

É isso que a minha leitura da narrativa pretende ser, uma evocação de sentidos em busca de uma rede organizada de obsessões. Os temas foram emergindo da própria narrativa e me deixei levar e seduzir por eles. O método foi o mesmo usado por Roland Barthes em seu livro "A Câmara Clara" ${ }^{21}$. Num primeiro momento o meu interesse foi constituído pelo studium da entrevista, esse primeiro elemento é definido por Barthes como:

“... uma vastidão, ele tem a extensão de um campo, que percebo, com bastante familiaridade em função de meu saber, de minha cultura; esse campo pode ser mais ou menos estilizado, mais ou menos bem sucedido (...) mas remete sempre a uma informação clássica: (no caso das fotos apresentadas no livro) a insurreição, a Nicarágua, e todos os signos de uma e de outra, combatentes pobres, em trajes civis, ruas em ruínas, mortos, o sol e os pesados olhos índios." (1984: 44-45)
\end{abstract}

Desse campo vasto muitas histórias/fotografias podem gerar uma "espécie de interesse geral" e a escolha inicial se dá por identificação moral, cultural e política, sem acuidade particular: "O studium é da ordem do to like, e não do to love", é o campo que nos permite fazer a primeira seleção.

Considerando esse elemento escolhi o campo Adálio. Dentre as narrativas de inúmeros soldados da borracha e moradores da comunidade Santa Marcelina, Adálio me atraiu, Adálio me capturou pela maneira como contava sua história. O studium nesse aspecto remete a entrevista como um todo.

O segundo passo foi escolher nesse universo, nesse vasto campo que é a narrativa de Adálio, do que falar e como abordar. Essa etapa exigiu outro elemento que nos é dado por Barthes: o punctum. Nesse caso, as minhas escolhas partiram “... da cena, como uma flecha que vem me

${ }^{21}$ BARTHES, Roland. A Câmara Clara. Rio de Janeiro, Nova Fronteira, $3^{\circ}$ ed., 1984. 
transpassar” (1984: 46), ou seja, algo na própria narrativa me chamou. Deixei-me guiar pela idéia dos "pontos sensíveis", das "marcas", da "picada", é o punctum de cada momento da narrativa que me levou as escolher. Esse momento diz respeito a algo mais particular, mais íntimo.

Em muitos momentos me utilizei de dicionários, vários deles, de símbolos, de cultura brasileira, de expressões, também usei os buscadores da internet, os intertextos da internet e os relacionei com o hipertexto Adálio.

O Próprio texto foi pedindo reflexões diversas, cada ponto sugeria relações com textos literários, com o cinema, a música e o teatro. Deixei-me levar e busquei aquela abertura do simbólico", de que nos fala Orlandi (1996), quando interpretamos. Para ela a "interpretação é um "gesto" e esse "gesto da interpretação se dá porque o espaço simbólico é marcado pela incompletude, pela relação com o silêncio. Sendo, portanto, o texto multidirecional enquanto espaço simbólico.

O que o leitor lerá a seguir é a minha rede de obsessões gerada pelo texto de Adálio.

Para facilitar a referenciação, indiquei no corpo da análise um número que possui um correspondente na narrativa de Adálio, então o leitor pode saber qual ponto do texto está sendo analisado e pode, também, ver a questão no contexto maior da narrativa.

Fiz uma leitura corrida das duas Narrativas: a entrevista e a música. E para facilitar dividi a leitura da mesma maneira como apresentei a transcriação: A palavra contada: A Jornada, A Escola, Os Sonhos, A Música. Depois, a Palavra Cantada, onde busquei pensar nos pontos de encontro e desencontros desses dois modos de narrar. 


\section{A PALAVRA CONTADA}

\section{A JORNADA}

Adálio inicia sua narrativa a partir do momento em que deixa sua cidade no Nordeste para vir para Amazônia: o "Eu saí pra cá" (1) indica movimento, deslocamento e, ao mesmo tempo, ruptura. "Eu saî", do Nordeste, "pra cá”, para a Amazônia, essa é a “origem voluntária”, o eixo desse momento narrativo que chamamos "Cápsula Narrativa". Ao ser estimulado a estabelecer por si só uma narrativa que se originasse da sua livre escolha, de como e por onde gostaria de começar a contar sua experiência, numa entrevista que evitou os ordenamentos marcantes que formatam a fala do outro, sempre começando com o nome, o nascimento, a filiação, e que vai sendo moldada por uma série de perguntas, Adálio escolheu como princípio e origem da sua fala a "Ruptura" que se dá a partir da saída, que podemos identificar como a viagem. A viagem, o ato de viajar, sempre esteve associada à idéia de "percurso", "caminho da vida" onde vários obstáculos precisam ser superados (Lexikon, 1990), a "Jornada do herói” (Campbell). Mas aqui a viagem que é empreendida não foi escolhida, foi forçada, a busca, que é a motivação da jornada, não era de Adálio, ele foi retirado, obrigado a partir, foi obrigado a romper com uma vida e foi jogado numa outra. A Ruptura aqui está simbolizada pela rachadura que se dá na própria vida de Adálio. Segundo Chevalier e Gheerbrant (2003: 792) "toda ruptura simboliza, ao se manifestar, a dualidade de todo ser: tudo o que é vivo e construído, pode ser morto ou destruído", a ruptura é a fase negativa que precisa ser dominada e domada para se alcançar um outro nível espiritual, agora o "deleite moroso" da ruptura coloca a pessoa na via de regressão e da involução (2003: 792). Ao associarmos a viagem de Adálio a uma idéia de ruptura, percebemos que não houve escolha, logo, não houve busca, não ocorreu a "jornada do herói", mas uma antijornada. Ou melhor, uma jornada forçada. O "Eu saí pra cá" indica a esperança da volta e do retorno, simplesmente saiu, não veio, não migrou, não viajou, não empreendeu jornada. O "Eu saí" indica também que ele não é o herói desse percurso, ele não toma as rédeas da jornada, ele é levado. A experiência de Adálio é a experiência do homem comum, é o percurso de milhares de pessoas que não conseguiram, que fracassaram, que perderam: daí a importância da sua vida e da sua narrativa, ela é emblema dessa "comunidade de destino": homens e mulheres que se desviam da sua jornada, da sua "bem aventurança", das suas escolhas pessoais para se tornarem joguete. Uma vida que foi um joguete de "grandes forças sociais", que foi arrastado de uma região para outra e foi sendo destroçada, ficando pelo caminho, perdendo amigos, parentes, filhos, mulheres, cidades, pertences, terras, dinheiro, partes do corpo, e inicia sua narrativa dizendo 
"Eu", ainda consegue manter os limites de uma identidade pessoal mínima, a dignidade que não se vai como a perna ou os dedos. Mesmo num lugar impessoal, com uma "vida hospitalar", prisioneiro por uma doença de afastamento social, ainda assim, Adálio consegue manter esse "Eu" que guarda histórias, que mantém acesa a palavra, o verso, a negação do lugar, a vontade viva de participar, de se dizer, de contradizer. Esse "Eu" não somente inicia a cápsula narrativa, mas será seu espírito, seus labirintos, suas estratégias.

A vida aqui, enquanto começo temporal narrativo não começa quando nascemos, mas quando sentimos um "terremoto", uma "clivagem", um "corte vital" ou a passagem de uma soleira (que no Nordeste significa mudar de vida, iniciar, seja como no nascimento, no casamento, na morte). Essa é a noção de "nascimento voluntário". A entrevista inicia por esse momento que não somente principiará o texto, mas será seu eixo temporal. O “antes" será contado "depois" exatamente porque esse antes só terá sentido quando esse depois for contado. Se fosse contado numa ordem linear, tradicionalmente historiográfica, deixaria de ter a densidade dramática, o poder teatral que faz com que as peças de teatro normalmente comecem quando tudo já está "no meio" ou quase no fim: Édipo já matou Laio, já está casado há muitos anos com Jocasta, cheio de filhos e feliz quando começa a tragédia.

O deslocamento tem uma razão: "Por causa da guerra de 1939" (2), esse é o motivo da viagem, é a soleira do "Eu" inicial. Algo externo, maior que sua vontade, retira-o do seu lugar, da mesma forma que a seca expulsa Fabiano. E Adálio vem nessa expulsão anunciada no fim de Vidas Secas: "E o Sertão continuaria a mandar gente para lá. O Sertão mandaria para cidade homens fortes, Brutos..." (Ramos, 1998). No Caso de Adálio foi a Guerra de 1939 que o forçou a migrar. A Guerra é um estado de suspensão, de combate, constitui a imagem da calamidade universal, e essa era uma guerra mundial. Interessante pensar como algo tão distante, uma guerra na Europa, pudesse afetar e modificar a vida de um nordestino no interior do Ceará. O homem comum é alistado, é arregimentado, é trazido para a batalha, alguns assumem a nova vida e seguem e acreditam ser os únicos a poder realizar algo, aceitam a missão, outros continuam as jornadas como joguetes ou esperando que tudo aquilo acabe logo para poder retornar. E ele veio para a Amazônia, que assim como a "cidade", representa um mundo diferenciado daquele do Sertão, são homens fortes e brutos, nos Seringais da Amazônia eram chamados de "Brabo", homens que ainda não estavam adaptados ao trabalho do corte da seringa. Essa resistência do sertanejo "sobretudo um forte" (Cunha, 2001), se revelará na maneira como se entregam ao trabalho e como conseguem se adaptar às intempéries da vida. Ter que abandonar tudo, abandonar a terra natal, viver sozinho, perder a família, em busca da sobrevivência, seja da guerra, seja da seca. E esse forte é, sobretudo, ideológico, porque foram mandados de um lado para o outro como fracos, são destruídos em Canudos e em qualquer lugar que o poder quer, ficando somente a história dos outros, e os adálios desaparecem. Essa idéia do 
Sertanejo e de seus valores "lendário" de serem "fortes", "bravos" e "corajosos", como o tipo ideal para defender a humanidade, era a base da propaganda getulista que se destinava à convocação para o recrutamento no exército da borracha, além de apelar para os sentimentos cívicos e patrióticos. Adálio aparentemente nunca se convenceu desses argumentos, veio forçado, não queria sair do seu lugar. Embora nem sempre esse discurso tenha sido eficaz, como podemos perceber na sua narrativa, quando ele assume que migrou por medo de servir na guerra. A opção Amazônia se apresenta para o nordestino como dupla fuga: da guerra e da seca. No caso de Seu Adálio especificamente, há sempre um distanciamento do discurso heróico de ter sido soldado da borracha, na verdade promove uma desconstrução desses discursos, quando assume que veio por medo e que na verdade preferia ter ficado com sua mulher e ter visto sua filha nascer. Ao mesmo tempo, seu relato pede reconhecimento e grandeza, sua saída tem "grandes e graves razões", requer que ele assuma certo heroísmo, e aos poucos esse "Eu" começa a ser incluído num movimento maior, numa jornada coletiva, nacional, brasileira. Aparecendo em seguida redimensionado num "nós".

"Nós viemos contratados como soldado da borracha" (3), Ele assume a condição na qual foi para a Amazônia, ele não estava só. O "Eu" que partiu do nordeste se mistura com os mais de 60 mil soldados nordestinos que foram levados à Amazônia pela propaganda e discurso ideológico do governo de Getúlio Vargas, durante o Estado Novo, para atender à necessidade político-econômica de garantir a produção de borracha aos Aliados na II Guerra Mundial. O plano era de obter o máximo de borracha, em um mínimo de tempo. Para tanto, se fazia necessário o recrutamento de mão-de-obra para essa batalha. Os "soldados da borracha", como foram chamados, seriam heróis de guerra tão importantes quanto aqueles que estavam nas frentes de combates da II Guerra Mundial, pois, o exército da borracha teria a missão vital de salvar os países aliados do colapso, face à falta da borracha para a indústria bélica. Com base nessa idéia é que foi construído o discurso e a propaganda de valorização do "Soldado da Borracha", para sensibilizar a opinião pública nacional e motivar os sertanejos para o recrutamento. No decreto-lei de fevereiro de 1943, Getúlio Vargas encorajava os sertanejos pobres a colaborar com o Brasil naquela luta patriótica, tornando-se Soldados da Borracha; em troca, além do dever cívico e patriótico, ele seria conhecido como o herói da Pátria e receberia uma viagem de caminhão, trem e navio por mais de cinco mil quilômetros até o "El Dourado", além do prêmio para aquele que conseguisse extrair mais "ouro branco", e ficavam "isentos" do serviço militar. As famílias dos voluntários, também seriam amparadas, com alimentos, escolas e assistência médica. Esse novo lugar na "história" requer grandes nomes, grandes eventos, grandes negócios, grandes contingentes e grandes traições, o que vai aparecer em todo o primeiro parágrafo: "Osvaldo Aranha, que era o primeiro ministro", "Getúlio Vargas", "Nações Unidas", "Eu estava no meio de 35 mil homens", "para o serviço para o americano", "não podia entregar o Amazonas para o americano" e "desamparados no meio do mundo" (4). 
Sua pobreza, sua miséria, sua doença e solidão exigem um começo épico e uma grande traição para ter chegado a tal ponto. É como se ele fosse do paraíso ao começo do inferno. Aqui estou como Lázaro, mas comecei como Ulisses, ele diria se soubesse dizer, mas é isso que ele diz, é isso que ele põe como abertura do seu texto-vida.

No primeiro parágrafo se desenha uma trajetória, uma visão de mundo e muito do tom geral do texto, inclusive suas dicotomias, angústias, descrições e justificativas. Mas ele morava numa "cidade boa, rica e muito produtiva". É como se dissesse que ali, doente e pobre, havia feito uma jornada de valor e que havia partido de um paraíso, que era alguém e, por isso, continua sendo. É um vislumbre do antes do "inferno verde", em pleno "paraíso perdido": "Antes eu morava no Ceará em Cascavel, era uma cidade boa, rica e muito produtiva" (5).

Mas era preciso deixar tudo, pois "A pessoa naquele tempo tinha era que obedecer! Eu tava casado e não queria vir, mas tinha que obedecer. Mesmo casado tinha que deixar tudo!" (6) obedecer como uma criança, não como "homem casado", "pai de família", aquele que pode socialmente mandar, ser respeitado, determinar seu destino, ser "cabra macho". Mas a obediência "naquele tempo" abre uma visão do presente como mais livre. É como se ele dissesse que agora não se precisa mais obedecer como criança. Pode-se assumir o destino e nitidamente, na sua narrativa, a saída é política (a música para Lula).

Nesse momento, Adálio revela a falta de opção, não era uma convocação, era uma intimação. Na sua idade, a opção era a Guerra, seja a da Europa, seja a da Borracha. As duas vias parecem falsas: "ou ia pra guerra ou vinha pra borracha” (7): ele vem não somente porque é mandado, porque é criança ou pobre, porque é nordestino ou sem poder, mas porque também acredita "no país", nos discursos que fazem a Nação nesse momento, e com esse acreditar, escolhe o melhor para ele. Satisfaz a pátria, a terra, o povo, a coragem de homem, de casado, de defensor e fica no seu país com uma missão inicialmente grande.

Nos dois primeiros parágrafos há: a) uma justificativa geral, histórica, social que põe o sujeito num grande e prestigioso quadro até b) o "bem dizer desamparados no meio do mundo"; c) uma reviravolta e justificativa para a vida do interior ("Cascavel, era uma cidade boa, rica e muito produtiva”); d) onde ele está casado mas tem que obedecer a lei maior (a) indo parar entre escolhas vitais "ou ia pra guerra ou vinha pra borracha": as linhas do discurso abrem-se e fecham-se. Ele explica e se justifica. Dispõe a arena da sua fala.

E temos o despojamento, "Pra vim pra cá tive que vender tudo, porque o que já se tinha de roupas, calçado, qualquer luxo que a gente tivesse, um relógio, uma aliança, não podia trazer nada" (8): novamente uma passagem, uma soleira onde se perde todas as posses pessoais e íntimas. Uma passagem dentro da passagem, perdendo todo luxo, até a aliança, que é "a expressão de um voto", de "uma comunidade, de um destino associado" (Chevalier; Gheerbrant, 
1992: 53). Perde-se a roupa e a esposa, a terra e a casa, os amigos e a comunidade, a história comunitária. A aliança escolhida, acostumada, "fielmente aceita" (1992: 54) é rompida, trocada por outra caracterização, outro homem para outra vida: "recebi uma mala de carregar nas costas com uma rede pequena, uma coberta pequena, um caneco de esmalte e um par de alpercata de rabicho. Uma calça de mescla e uma camisa de um pano ordinário que nós chama americano" (9). Essa "troca de trajes" (Cirlot, 1984: 578) não corresponde a uma troca de sexos, a uma orgia, mas mudança de culturas, de regiões, de relações; ao despojamento que no exército acontece no princípio (deixar de ser cidadão para se tornar soldado), e no fim, com a dispensa ou a degradação (o que Adálio sente é a degradação no começo). Aqui se caracteriza o outro, aquele que será dali por diante. O que foi antes e o que virá. Agora ele tem uma "carteira de $\mathbf{3}^{\mathbf{a}}$ categoria" (10), é alguém de terceira categoria, desenraizado, em suspensão. Por isso o discurso começar com as "dignidades".

Há uma idéia de que o "seu tempo" era um tempo de atraso, "Naquele tempo do atraso" (11), numa consciência nítida de mudanças técnicas, políticas, humanas, que fazem "desse tempo presente" algo melhor, com mais esperança não somente para ele como para os outros.

O trabalho fazendo a passagem desse outro homem: "cortei muita lenha! Passei um ano antes trabalhando no Rio Purus, fazendo lenha pra navio e trabalhando de todo serviço" (12). Esse "de todo serviço" parece um viés bíblico (trabalharás com o suor do teu rosto; sete anos teria que trabalhar Jacó para conseguir casar com Raquel). Com o trabalho, o "todo serviço" do ser indeterminado, sem lugar, se faz a passagem para uma outra condição, que se deseja seja melhor, que se realize o sonhado depois desse compasso de espera. Mas no tempo do contar já não há dúvida quanto ao desfecho. Daí a tensão aberta para essa vida que se faz e se fará no texto. Não é "trabalho executado de boa fé, constância e consciência de colaboração na obra geral” (Cirlot, 1984: 577), mas ações aleatórias, serviços numa espera, fora da sua vontade, integrado numa "vontade maior", daí o tom de "má-vontade" da passagem e de posicionamento e crítica: "Eu vim obrigado" (13), mas não é pelo "com medo da guerra" (14), o que exime o mundo que o fez se desalojar de sua terra para "outro mundo". Trazer para ele a culpa, nesse momento, é não somente dúbio, como mostra o quanto ele participa do jogo com as crenças tradicionais da pátria. Seu discurso confirma o discurso maior, exime-o de culpa, pois a culpa é dele (medo da guerra). O "mas tinha que obedecer" (6) esconde sua adesão, sua participação, não seu medo ou suas perdas.

A viagem de Adálio não é aquela que é uma "busca da verdade, da paz, da imortalidade, da procura e da descoberta de um centro espiritual" (Chevalier; Gheerbrant, 1992: 951), mas a viagem por obrigação e por crença. Ele é o brasileiro que se orgulha e justifica essa crença, o discurso maior que vai arremessá-lo em outra vida. 
E para iniciar essa nova vida foi preciso percorrer um trajeto: “Aí nós viemos até Coroatá no Maranhão de carro. Agora do Maranhão pra frente nós viemos num trem. Era um trem de carga, com muitos carros, e vinha cheio de muitos homens (...) E o que é certo é que cheguemos em São Luís, onde tive uns dias lá num pouso chamado Maracanã. Adispôs, embarquemos numa barcaça para embarcar num navio maior chamado Itapuí da Companhia Ícaro, lá no meio do mar. Ia levar a gente para Belém” (15). Nesse trecho muitas imagens aparecem, o trem, por exemplo, aparece aqui nesse momento e reaparece na narrativa sobre sua infância e a saída de Aurora para Cascavel: "O trem do sonho é a imagem da vida coletiva, da vida social, do destino que nos carregam. Evoca o veículo da evolução, que dificilmente tomamos, na direção certa ou errada, ou que perdemos; simboliza uma evolução psíquica, uma tomada de consciência que prepara uma nova vida" (Chevalier; Gheerbrant, 1992: 897).

Essa descrição do bombardeio ao submarino alemão (16) é um episódio recorrente nas narrativas de muitos soldados da borracha.

Essa nova vida é justificada a partir de um discurso patriótico: "veio essa notícia do Ministro Oswaldo Aranha, que não aceitou o negócio do Presidente Vargas com o americano. O Presidente Vargas tinha dado os seringais todinho pros americanos tomar conta. E nós vinha como soldado para o americano, nós não vinha por conta do governo brasileiro não. A companhia era americana. E o que é certo é que o Osvaldo Aranha chegou lá das Nações Unidas, não aceitou e disse que não aceitava não, porque quando o americano empossasse, tomasse conta do Amazonas não queria entregar mais, mesmo com o fim do contrato" (17).

O discurso patriota, que tenta explicar aquilo que fez sua vida ir de um lugar para outro, vida trabalhosa e dolorida, é composto, desde o princípio, por um claro discurso "histórico", isto é, aquele que utiliza os artifícios historiográficos (no caso chegados através da sua educação formal, por jornais, rádio e conversas entre pessoas sobre a "atualidade”). Com esses discursos entrelaçados não somente a vida ganha sentido, mas a dor pessoal tenta conquistar uma grandeza maior que ela mesma. Ganha companheiros, causas, guerras, viagens, terras, rios. E esquece sua minúscula miséria, que esses discursos faz sobressair, faz aparecer com grandeza maior. O sentido é inverso do pretendido. Em vez do grande herói, o desgraçado por nada, o anti-herói, a anti “jornada do herói”. A indicação 17 é essa tentativa com maior profundidade. A justificativa do anti-herói. Não há aqui o "grande homem", aquele que se sobressaiu por seus feitos, por suas idéias, mas aquele pequeno homem que foi joguete, foi "bucha de canhão", foi "massa de manobra", foi, durante toda a história, usado e jogado fora. E aqui ainda legaliza e explica, não somente os "grandes homens" (Ministro Oswaldo Aranha, Presidente Vargas), os "grandes fatos" e instituições, mas põe esses discursos como inaugurais, isto é, aquele que lhe daria uma origem heróica. Mas diante do homem Adálio e do 
seu texto o que podemos sentir é o inverso do pretendido. Para serem ou parecerem verdadeiros os grandes discursos precisam de grandes pompas, grandes lugares, grandes momentos. Adálio exatamente por dizer de onde diz (leprosário), fisicamente como diz (aos pedaços), economicamente como diz (sem nada), inverte o sentido dos discursos envolvidos e os expõe em sua crueldade e função, que ele mesmo pressente e se ressente, como todo Soldado da Borracha (abandonado depois de usado). Mas essa consciência não desconstrói nem generaliza os mecanismos. Os discursos continuam a serem usados como se não fizessem parte do conjunto.

O discurso historiográfico-patriota não é um elemento a mais, algo desprezível, um artifício usado como propaganda, mas componente intrínseco a todo o processo. Ele não poderia faltar. Sem ele não haveria Soldado da Borracha, Estado Novo, Brasil, o trabalho, a obediência a um chefe, a uma ordem de trabalho. Sem as crenças fundamentais de indivíduos e grupos a estrutura social não se moveria. Os processos gerais de crenças não são reflexos da "estrutura econômico-social", mas aquilo que gera indivíduos, grupos, funções, classificações, e justifica para eles mesmos seu dia-a-dia, sua vida, seus desejos, dores, nascimentos, doenças, acidentes e mortes. Quem cria os filhos não são "estruturas históricas", mas as crenças mínimas dos pais, dos parentes, dos amigos, das relações que vão se alargando e pondo o indivíduo no seu lugar, com sua própria cumplicidade, a acreditar; mesmo que ele não concorde e sofra, realiza a rede de crenças e se põe no seu lugar, produzindo, procriando e lutando por seu lugar (Adálio se ressente profundamente por haver perdido sua terra quando adoeceu e teve que deixar para outros o seu lugar).

Quando as levas de Soldados da Borracha chegavam e eram tratadas como escravos, como instrumentos de produção, como gado, podia haver certa indignação (talvez sentida somente no texto, não fazendo parte do momento do viver), mas era sempre uma indignação integrada, esperançosa de ser escolhido para realizar seu lugar, o discurso, a crença, o esperado, pois todos estavam ali com o mesmo espírito, a mesma missão: “os patrões do Acre, do Amazonas mesmo, chegava tirava assim: um patrão chegava tirava vinte, outros chegava tirava trinta, outros escolheram gente morena que era mais resistente, por causa do tifo, outros escolheram gente da perna fina, que não eram preguiçoso. Isso tudo acontecia com o soldado da borracha" (18). E as ações com coisas e gado aparecem: o "patrão chegava tirava vinte, outros chegava tirava trinta". Há uma ação geral de indiferença e horror (quando é bicho é normal, faz parte, quando é gente é shoá), como se um feitor ou senhor de engenho comprasse escravos numa feira ou um vaqueiro encolhesse para a ordenha ou para o abate vacas num curral. E as classificações aparecem: "gente morena", com sua função escravista, por ser "mais resistente"; "gente da perna fina", que sempre trabalhou e não teve tempo de engordar e, por conseguinte, "não eram preguiçoso". Figuras do escravo e do trabalhador, do negro e daquele que resiste. 
Adálio chega a usar o termo "manada", mas noutro sentido: "teve uma manada de carioca que adipôis que caiu a companhia americana voltou tudo pra trás, voltaram tudo pro Rio, o governo deu passagem de volta. Eles vinham atrás é de aventura, não era de cortar seringa, mas não sendo pro americano não vinha pra cá nenhum. Eu acho até graça quando lembro disso!" (19). Aqui ele não usa o "manada" para si mesmo e para os seus, mas para os "carioca", sulistas, brancos? não escravos? Com certeza, signos de outras figuras, fracos e, por isso, não dignos de "cortar seringa". E ele acha "graça" quando lembra? Quais os sentidos que se cruzam aqui nesse riso? A justificativa e a crença. Aqui ele expõe sua concordância com o processo que o carregou. Ali deviam realmente estar homens fortes, não "carioca", mas machos que dessem conta. Daí seu riso. Eles voltaram do meio do caminho, não se tornaram Soldados da Borracha. Riso estranho esse. Não tiveram seu destino nem o destino de milhares de "machos", corretamente escolhidos pelo Estado Novo, pelo Brasil em guerra.

E o "manada" é usado para si mesmo e para os companheiros: "chegou minha vez. Eu vim numa manada de duzentos" (20). Como há um feixe de contradições entre discursos e vida, entre narrativa e experiência, o justificável e o injustificável na mesma visão, é com a resultante que temos que trabalhar. A consciência de manada não dissolve seu "discurso historiográfico", mas vai de mãos dadas com ele como se fossem da mesma matéria. E são! Há um elogio do patrão de admiração: "um patrão chamado Matias Quaresma que era um dos patrões mais ricos aqui do Amazonas" (21). Não foi para qualquer patrão que ele foi, mas para o maior, o melhor, o mais rico, o que tem nome e sobrenome (sobrenome que Lima Barreto deu ao seu louco nacionalista em “Triste Fim de Policarpo Quaresma”). Mesmo vindo "numa manada de duzentos", ele aqui enaltece a grandeza do patrão mostrando a qualidade dele mesmo como trabalhador que não era "gente morena", que era a "mais resistente", nem tinha "perna fina", porque sempre trabalhou e não era "preguiçoso". Não era nome de "baixa qualidade" (a grandeza do senhor enobrece o servo), mas "Antônio Noronha de Brito Morais e esse Noronha de Brito veio do Conde dos Arcos, ouviu? Gente que veio nas caravelas, ouviu?" (Suassuna, 1964: 47).

As trilhas de crença e respeito do Nordeste não deixam de falar através de Adálio. E como "um forte" ele não vai para "um serviço mais maneiro" (22), o que o desqualifica aqui na palavra, mas "pra uma colocação de seringa chamada Rarizal, cortar seringa" (23), o que o qualifica, aqui no texto, como alguém digno não somente de todo o processo como de respeito por ter sido "um forte" como todo sertanejo. O que se confirma depois de dois parágrafos de uma descrição dos afazeres dos seringueiros, de suas dificuldades, doenças, fome e sujeições quando termina dizendo epicamente: "muitos morreram, mas eu sofrendo muito atravessei" (24).

A importância de todo o trecho não está na descrição, mas no poético "muitos morreram, mas eu sofrendo muito atravessei”. Aqui não somente está a força, mas a confirmação (da 
história, do relato, da vida, do sofrimento). A morte de muitos realça seu relato e a sua travessia, enquanto o sofrimento engrandece o caminho, dá sentido ao sofrimento, que é purificador para todo cristão, devendo sofrer a travessia para que isso tenha valor perante Deus. Adálio aqui tenta dar uma nova dimensão ao seu trajeto: "a travessia simboliza justamente o esforço de superação e a consciência de tudo que o acompanha" (Cirlot, 1984: 577). Ao mesmo tempo o valor da sua fala, da sua experiência: "muitos morreram", estão piores do que eu, não podem dizer mais nada, foram calados, eu estou aqui vivo, muito sofri, mas "atravessei” e estou aqui para confirmar, para dizer que vivi, que sou um forte, que ultrapassei a "selva escura" de Dante.

Adálio diz, "Cansei de produzir" (25), mas o trabalhador não cansa de produzir no sentido literal de exaustão exigindo descanso, sono, fuga, descrença, de abandono da produção, mas no sentido de haver produzido muito e sentir orgulho com esse "cansaço", inclusive sentir saudade por não estar mais trabalhando e produzindo. Ele é a resultante do que deveria ser feito e foi.

Exatamente porque ele não entra em afasia, não fica "a passos lentos", não aderna, não se ajoelha, não afunda, não se torna "água estanque", não amolece, apodrece, não cai de sono, não fica chumbado, não "entra em colapso", não fica com "passo de lesma”, não é covarde, coxo, nem "dá de costas"; não "dá tempo ao tempo", não "vive de mansinho", de rastros, de vagar; não definha, não se deita; não fica depauperado, em depressão, derreado, derretido, desalentado, desandado, desfalecido, desfeito, desmaiado, desmontado, desvirtuado, detido, digerido, dormente, dorminhoco, em muletas, embargado, embromando, emburricado, empacado, emperrado, encangado, enfadonho, enfraquecido, engrotado, entorpecido, entrevado, esborrachado, esmorecido, espetado, esponjoso, estagnado, estancado, sentado, deitado, estático, estável, estéril, estropiado, estuporado, exausto; com "falta de forças" ou faniquito; não "faz pé atrás"; fica firme, fixo, sem flacidez, fraqueza, freio, frouxidão, fugir; sem hibernação, imobilidade, impotência, improdutibilidade, inatividade; sem infecundidade, infertilidade, insuficiência; sempre "feliz no lamaçal", na lassidão, no lastro; produzindo contra a lentidão, a lesma, a letargia, o limo, o lodaçal, o luto, a malária, o maleável, o manco, a mandrice; sem manquejar, sem marasmo; sem mugir, sem se mover, sem se precipitar, narcotizado, opresso; sem travamento, sem travar os passos, sem vadiação, sem andar à gandaia, sem vergar (Spitzer, 1952; Cascudo, 1954): daí o orgulho sem medida do trabalhador, sendo esse orgulho parte constitutiva do seu caráter, da sua visão de mundo. O trabalho é, para ele, conquista, honra, uma dignidade sagrada, parte da comunhão entre os homens e Deus. Esse é o sentido e a força das suas crenças. Isso sempre foi usado muito bem por todas as classes que detêm a formação, o mando, os instrumentos e os meios de produção. O não se dobrar e produzir com alegria para o senhor, para o patrão, para a terra, para a Pátria, para Deus, para a família, para não se tornar um inútil é o que, no fundo, move as relações de exploração e produção do real (Grupo Krisis. Manifesto Contra o Trabalho. Conrad, São Paulo, 2003). Sem a justificativa visceral do próprio trabalhador não haveria 
não somente o trabalho como o conhecemos, mas a ordem social que faz com que Adálio não somente sofra como abone a todo o momento, consciente ou inconscientemente, o universo do trabalho e sua ideologia. Por isso ele não se cansa verdadeiramente. Esse cansaço, não sendo senão orgulho de trabalhador, ele é signo de um sistema mais vasto que põe luz sobre Adálio e seu trajeto, escolhas, mudanças, sofrimentos. Torna mais compreensível sua anti-trajetória e sua posição de antiherói, explicando as infinitas "duas toneladas por ano" (26) sem cansaço real e orgulho em dizer o tamanho da sua capacidade e produtividade. Ele não canta nem pode cantar como Clementina: “Fui feita pra vadiar/ vou vadiar, vou vadiar, vou vadiar".

Essa força não impede nada, não cria estabilidade, prazer, estando mesmo na sua consciência a instabilidade dessa vida: "essa casa que eu tava trabalhando quebrou, ainda ficou um saldo lá para me pagarem e não pagaram. Saldo pouco, dinheiro pouco. O patrão forte quebrou. Me mudei pra outro e aí fui assim bolando e sofrendo" (27). Não é feita uma relação entre suas crenças no trabalho e sua condição de joguete, isto é, aquilo que rola de um lado para o outro conforme a necessidade dos patrões. Nem se une completamente, até mesmo no "fim do jogo", todos os fios que tornaram uma vida mais dor e sofrimento que um momento de paz. O trabalho e suas crenças não conseguem desvendar o porquê do se viver "bolando e sofrendo" e se terminou aos pedaços e na miséria. E o pior é que se essa vida não tivesse empreendido uma "viagem", mudança de regiões e mundos, teria permanecido como os que ficaram na sua "terra natal", também cumprindo as crenças elementares da produção e da reprodução, sentindo no fim que viveram somente "bolando e sofrendo", como confirmam muitas entrevistas de outros projetos de pesquisa, com outras "colônias e redes".

Esse ir bolando tem relação até com a terra, o patrão, o trabalho: "Ali eu me dei bem! Comecei a trabalhar, o patrão pagava bem um saco. Esse homem se desnorteou, se desmantelou e também foi abaixo. E assim eu fui, também” (28). O se dar bem é provisório, depende do outro, não é conquista, é momento. Quando esse outro se desnorteia, se desmantela, ele também se arruína, deve bolar e ir sofrendo, continuar e se inserir noutro sistema que é o mesmo, sendo esse o percurso da não vontade, do não domínio (a trajetória do anti-herói), do eterno retorno, do permanecer pensando que muda.

Enquanto o herói das mitologias avança e toma conta voluntariamente dos seus passos, das suas relações, do seu projeto, conquistando a força necessária para vencer as tentações de mudança de rumo, de despersonalização (Campbell, sd.), o trabalhador (no caso Adálio), é um mão-mole, que é um jogo nordestino onde as crianças "deixam ir a sua mão à vontade do agente, batendo-se-lhe com ela vez por outra no rosto e no peito, dizendo 'mão-mole', 'mão-mole"' (Cascudo, 1954); ou mamulengo, onde "Por detrás de uma empanada, esconde-se uma ou duas pessoas adestradas, e fazem que os bonecos se exibam com movimentos e fala", tudo sendo animado "pela mão do encenador" 
(1954). A condição de marionete do destino, da natureza, de pau mandado de algum coronel, aparece em quase todos os "livros regionais", principalmente nos do período 30 e 40 do século XX, seja em Graciliano Ramos, em Raquel de Queiroz, em José Lins do Rego, ou mesmo em Jorge Amado. O jagunço, o político, o retirante, o trabalhador, a mulher, a criança, o negro, o pobre, o lavrador são tipos desse mamulengo.

Essa condição pode arrefecer quando há a sensação de haver se tornado um "senhor", com uma terra somente sua: "comprei um lugarzinho com uma economiazinha que eu tinha e estava morando agora de sitiante e tava muito bem" (29). Quando se torna seu próprio patrão parece que a roda da desfortuna vai enfim parar e ele poderá descansar. Mas ele já sabe que os patrões quebram, afundam, perdem tudo e que isso não é segurança. Mas naquele momento ele está "muito bem", tudo porque ele agora sabe que "esse lugar é meu" (30). E descreve com orgulho, mesmo com percalços, seu lugar: "o meu lugarzinho tem uns quinhentos metros de frente, 1400 de fundo. Mas na entrada não deu de fazer a casa porque tem uma água, com 150 metros tem uma água. Aí fui fazer a casa mais na frente, no meio do lote porque lá a terra era alta! E fiz essa benfeitoria. Mas, eu trabalhei esses vinte anos lá todo tempo. E esse lugar é meu!" (31), e esse situação dura "vinte anos".

No Nordeste se chama "visita da saúde". Antes da morte o doente se levanta, conversa, parece estar bom. Depois se deita e morre. É essa a imagem dessa passagem inteira (notas 29 a 36). Como se fosse a descrição cruel de uma derrota.

Essa terrinha conquistada depois de muito trabalho (onde ele enfim está "muito bem") começa a ser rondada por indivíduos que a desejam e a invadem quando ele, sozinho, se ausenta: "quando foi num dia que eu vim aqui para cidade, tinha uns camaradas que tava enfezando, botando animal porque pra lá ninguém trabalha e quando tem um que trabalha eles fica de cima, perseguindo, soltando animal dentro do meu lugar pra estragar” (32). Quebrando as cercas, deixando os animais entrarem para comer suas plantações, fazendo da vida um inferno, sem que apareça alguém para ajudar como nos filmes de faroeste ("Os Brutos Também Amam”), ou como em "Os Sete Samurais" de Akira Kurosawa, onde uma aldeia explorada e aterrorizada por "bandidos" é defendida e posta em paz por "sete samurais".

Sua terra era enfim o paraíso conquistado: "Porque tinha muito milho, macaxeira e plantação como laranja, biribá, esse limãozinho nosso legitimo e cupuaçu, e muita mangueira, coqueiro. Tudo isso eu deixei plantado lá!" (33). Cocanha (o "em lá se plantando tudo dá" de Caminha) depois de sair do deserto, depois de trabalhar para nada, de não ter nada e juntar um pouco durante décadas para conquistar uma lasquinha de terra. Lugar de tudo ter (terra, água e vegetação), tudo ser verde ("laranja", "limãozinho"), ser aquoso ("coqueiro”), ser suculento ("milho", "cupuaçu”, "mangueira"). 
Mas ele não ia perder isso por nada. Sua condição de macho não havia se perdido, mas reforçada pela terra, pela água, pela energia do trabalho. Ele não ia deixar tudo sem defesa: "E eu ia comprar uns cartuchos de bala pra eu me garanti mais. Eu queria atirar nos animais e até em gente se fosse preciso, porque eles queriam invadir o que era meu" (34). Essa terra tem dono, tem quem a proteja. Esse paraíso sempre lembrado depois com saudade e impotência não será dado de "mão beijada". Mas a desdita, o mal caminho, a trajetória do anti-herói não pode terminar assim.

Não há bate-boca, tiroteios, morte, violência, saque. Nada daquilo que acontece todos os dias nos inumeráveis "conflitos de terra". Adálio, o anti-herói, tem um anti-clímax: "carreguei um volume de uns 36 quilos na costa, 800 metros pra ir pra casa, (...) aí saiu uma borbulha assim do lado do meu pé direito. Deu uma tal de infecção e aí eu vim pra cá” (35). Calma e ridiculamente "o Horror, o Horror" de Joseph Conrad no "Coração das Trevas". Nenhum épico, mas uma "borbulha", uma bolha d’água "assim do lado do meu pé direito". Aí vem "uma tal de infecção" e ele termina perdendo todo o seu paraíso, sua Cocanha, seu estar "muito bem", seu sossego, para terminar vindo "pra cá", isto é, para o leprosário, para o "apartamento" (apartado de tudo e de todos). Não somente perde tudo, mas perde, dessa vez, de uma forma mais radical que das outras vezes. Ele não perde mais enquanto trabalhador que é marionete, coisa que é jogada de um lado para o outro, mas perde tudo; deixa, para ele, de ser homem, é o fim. Não somente perdeu o passado como perde o presente. Só lhe resta falar.

A descrição serve como um epílogo provisório: "eu cheguei aqui às oito horas da manhã e quando foi umas cinco e meia da tarde me cortaram a perna (36). (...) Aí invadiram tudo e carregaram tudo que eu tinha e eu fiquei sem nada! Só tenho o lugar, a casa também era de pobre, mal construída com assoalhado de açaí e coberta de palha de babaçu" (37). Perde a perna (pela primeira vez o corpo é dilacerado) e aí invadem e saqueiam sua terra. Ele fica "sem nada", que já era coisa "de pobre”. A perna e a terra são interligadas. Perder a perna se articula com a terra e a força do trabalhador. Sem ela, tornado agora uma marionete quebrada, não há mais sentido. E todos sabem disso. O saque à sua terra é a compreensão de que aquilo não é mais de um homem, e ele sabe disso. Ele não pode mais defendê-la, modificá-la, deixar para alguém, sentir orgulho. Nem ele mesmo é mais o mesmo. Um mutilado preso por isso.

E o discurso duplo, quase irônico, trazendo uma tensão monstruosa:"E daí pra cá eu tô vivendo aqui nessa comunidade. $E$ sempre me dando bem! $O$ povo aqui coopera bem com a pessoa. A gente tem um café pela manhã com pão, tem o almoço, tem a janta, tem roupa lavada, também tem a cama pra dormir. E eles assisti bem com o remédio. $\mathrm{E}$ se a pessoa que tá aqui no pavilhão se ele adoecer aqui levam pro hospital porque lá é aonde os doutor convivem e os enfermeiros, aí gente tem uma assistência medonha! Eu acho muito bom 
esse lugar, o pessoal trata bem da gente! É um povo muito bom, legal. As irmãs são boas, os doutor também são muito popular, são bom" (38). Depois que lhe cortaram tão rapidamente a perna ("eu cheguei aqui às oito horas da manhã e quando foi umas cinco e meia da tarde me cortaram a perna" (36) e lhe tomaram tudo, sem terra, sem casa, sem poder trabalhar mais, ele parece aceitar a vida "nessa comunidade". Seu discurso aqui parece de aceitação e elogio, quando na verdade é crítico, ressentido e violento. A violência não somente da ironia, mas daquele que impotente deve elogiar a quem o alimenta na jaula.

Aquilo que foi sentido nas entrevistas aparece aqui "por baixo do pano". As palavras e frases, imagens e sentimentos são positivos, mas dizem outra coisa. O "sempre me dando bem" faz pulsar por baixo sua situação de doente, de perneta, de mutilado, de prisioneiro de um lugar para quem está morto em vida. Lugar que "coopera bem” com essa situação toda. E aparece a sensação de esmola: "A gente tem um café pela manhã com pão, tem o almoço, tem a janta, tem roupa lavada, também tem a cama pra dormir. E eles assisti bem com o remédio". A comida é dada, é levada até ele, logo ele que sempre lutou por seu alimento com o "suor do seu rosto", com muita dignidade e orgulho: agora ele recebe a comida como uma esmola, uma dádiva, uma bondade, pela caridade de outro, desprotegido como se fosse um animal. A "pessoa que tá aqui no pavilhão se ele adoecer aqui levam pro hospital": a força está no "levam". Tudo agora depende dos outros. O processo de infantilização, de proteção, aparece como uma afronta. Esse sentimento transparece na duplicidade da palavra "medonha", "uma assistência medonha". Palavra dita por um nordestino pode significar "maravilhoso", "magnífico", "estupendo", "arretado" e, ao mesmo tempo, "pavorosa”, "tenebrosa", “o que causa medo", "o que provoca horror, repulsa”, o que é "atroz, execrável, revoltante", "extremamente feio ou mal, terrível, hediondo", o que é “excessivamente desagradável, difícil de ser suportado, detestável, desgraçado” (Dicionário Houaiss da Língua Portuguesa, Objetiva, Rio de Janeiro, 2001). A vida ali é "medonha", a comida é "medonha", a situação toda é "medonha", e nada disso é maravilhoso, ótimo, gratificante, recompensador: Adálio com o seu "medonha" diz tensamente sua opinião, no que sempre foi um contato atritozo, uma convivência entre opostos. De um lado "as irmãs" e do outro "os doentes" e ele como alguém que suportava tudo por não ter saída. E diz com muita tristeza e muita ironia essa relação ao multiplicar e repetir o "bom" e o "bem", ao enfatizar o quanto tudo é muito bom: "Eu acho muito bom esse lugar, o pessoal trata bem da gente! É um povo muito bom, legal. As irmãs são boas, os doutor também são muito popular, são bom”.

Mas o fracasso é dele, somente dele "Agora aqui o fracasso mesmo foi só o meu!" (39). A culpa da sua vida é trazida para ele. Ela seguiu um caminho que terminou em "fracasso". Ninguém mais pode ser responsabilizado. Ele assume a vida e seu fracasso como no começo do seu texto assume aquele "Eu" (1) que se manteve apesar de tudo. Esse "Eu" assume o "fracasso" como 
parte de uma história, de crenças e situações. Não separa, não exclui. Tudo está junto ali com um nome e uma vida. O tom irônico não deixa de atingir o lugar e as pessoas ao seu redor quando ele diz "Agora aqui" depois de elogiar todo mundo. eles também são fracassados. Fazem-no criança, animal, prisioneiro, brinquedo, mas ele assume o "fracasso" sozinho. Eles estão ali fazendo o trabalho deles e ele cumprindo seu "fracasso". E justifica seu horror diante da mutilação: "Porque um homem cortar a perna de uma pessoa é o mesmo que cortar o pescoço e fica a pessoa aleijada para sempre” (40). Não é mais homem, não é mais trabalhador, é o mesmo que estar morto, é o mesmo que "cortar o pescoço", ser sangrado como galinha, porco, boi, fazendo parte da "criação", dos bichos do lugar. E não é algo reversível pois "fica a pessoa aleijada para sempre".

Ali é o fim não somente de uma vida, de um corpo, mas de um sistema geral de crenças que tem na esperança um dos seus pilares. Essa esperança fica reduzida a esperar "uma perna, qualquer dia tiram a medida, mas só vai quando os homens chama. Ainda não me chamaram. E eu sentando nessa cadeira! Me deslocando pra cima e pra baixo" (41). Reduzido ao kafkiano esperar, becketianamente "Esperando Godot", sabendo que nada virá ("fica a pessoa aleijada para sempre"), esperar uma perna, uma medida para uma perna de madeira, mergulhado no calor amazônico, sufocado e cheio de angústia e solidão. Mas ele não é nunca chamado, passam as horas, os dias, os meses, os anos e ele não é chamado. Fica ali sentado na cadeira de rodas, "pra cima e pra baixo", enjaulado como uma fera, de um lado para o outro, isso é o "mesmo que cortar o pescoço", morto em vida, humilhado e sem futuro.

Sabendo ele disso, sentindo tudo isso, quando elogia, quando parece alegre, sente-se a ironia, a crítica, a tensão interna, sua discordância incontida com aquele mundo. E seu discurso se reparte aqui. A descrição do seu calvário tem um momento de descanso. Ele esgotou provisoriamente suas razões, justificativas, explicações. As condições estão dadas por ele mesmo. A grande história, seus caminhos depois dessa história, seu declínio pessoal, seu horror presente. O tom inicial, sua temporalidade pessoal, a ordem dos feitos e razões toma outro sentido. Seu "nascimento voluntário" não se deu como tradicionalmente se pensa (nascimento, pais, cidade de origem, etc.). Agora sim ele volta para os pais, o nascimento, a cidade de onde nasceu, ainda com uma justificativa, mas entrando num outro espaço, num outro tempo, numa outra narrativa. Agora ele vai começar a tratar desse outro Adálio, aquele que viveu "antes desse tempo" (42), antes da doença, da Amazônia, da Guerra da Borracha, antes desse eu destroçado, sangrado. O texto cria várias e pequenas dobradiças, aqui está uma grande dobradiça, aquela que leva para outro tempo, outro lugar, outra vida. Mas foi preciso dizer o que foi dito até aqui para que isso mesmo e o que veio antes tenha a devida dimensão. Começar pelo começo nunca é um bom negócio, uma boa literatura ou um bom texto, e Adálio intuitivamente sabe disso. Ele é um "narrador pleno", que são aqueles que mantiveram a sua 
"faculdade de intercambiar experiências" intacta (Benjamin, 1985: 198). O narrador pleno é o tipo de narrador que Walter Benjamin dizia estar desaparecendo porque as ações da experiência não eram mais consideradas. Um narrador pleno como Adálio, normalmente, é um pouco o "camponês sedentário" e também o "marinheiro comerciante". Carrega as duas experiências, a do viajante e a do homem do lugar. Isso faz dele um narrador especial, pois intercambia esses dois tipos de narradores: "A figura do narrador só se torna plenamente tangível se temos presente esses dois grupos [o camponês sedentário e o marinheiro comerciante]" (1985: 198).

Bem “antes desse tempo" (39) Adálio “tinha pai e tinha mãe!” (40), ele não é aquilo ali, não é isso aqui, um mutilado, doente, velho, inútil, abandonado e sem terra, sem amigos e dando "graças a Deus" por estar sendo cuidado num "berçário" feito uma criança pequena por suas "irmãs" "“tinha pai e tinha mãe!"). Ele não é só "soldado da borracha" (isso tem o mesmo sentido do "Antônio Noronha de Brito Morais e esse Noronha de Brito veio do Conde dos Arcos, ouviu? Gente que veio nas caravelas, ouviu?", de Ariano Suassuna no "Auto da Compadecida"). Ele tem mais história. Aqui, uma vai dar mais significado a outra. Ele não é o João-Ninguém em que a vida o transformou, ou mesmo o sertanejo que não vingou, que não viveu o resto da sua vida como sertanejo. Aqui ele articula as duas histórias. A que começa com o "nascimento voluntário" do texto vai agora fazer ver com mais profundidade sua vida anterior, e essa vida vai tornar maior e mais complexa essa primeira parte da sua escolha. Textualmente são complementares. A tensão construída em uma, vazia de minuciosa vida anterior, vai agora ser preenchida para multiplicar os sentidos, as dores, as perdas, o estar agora ali e por quê. Atos de um drama, de um enredo e seus momentos.

Nesse segundo momento ele nasce, significativamente, num lugar chamado Aurora: "Eu nasci no sertão do Ceará chamado Aurora!'(44). Um princípio feito de luz no sertão que é feito de sol. Aurora e Sertão, símbolos de origem, de despertar, de iluminação, similar a imagem da criança, primitivos e inauguradores. E no sertão Armorial de Ariano Suassuna, cada palavra, cada emblema, cada marca (as marcas do discurso, as dobras: o punctun, o biografema e o tema barthesianos sendo extraídos do próprio texto, vindo de sua "rede organizada de obsessões", como diz em seu "Michelet"), têm uma função maior que não escapa aqui ao narrador pleno que é Adálio. Ele quer fazer significar mais profundamente aquela vida narrada. Quer fazer com que ela conquiste o máximo de acordo entre o que ele sente, o que ele fez, o que o mundo fez com ele. Ele arrasta para o lugar certo o nome da sua cidade, tirando proveito dela. O que foi circunstancial torna-se essencial. A aurora "branca e rubra", a aurora "em traje verde e róseo" de Baudelaire (1985) são chamadas para compor um momento, tanto da entrevista (na percepção do oralista), quanto do texto (dimensão do leitor). A aurora que vem depois da "longa noite" (Chevalier; Gheerbrant, 1992: 101), a noite que antecede esse agora textual, que está antes, mas está textualmente depois. Os labirintos do texto exigem uma leitura hipertextual, também labiríntica para ser "ouvida". 
A aurora é, para Adálio, não somente um começo, mas "símbolo de todas as possibilidades, signo de todas as promessas (...). Com ela recomeça o mundo e tudo nos é oferecido”, mas onde “cada manhã (...) Com ela recomeça o mundo e tudo nos é oferecido. A aurora anuncia e prepara (...) a juventude" (Chevalier; Gheerbrant, 1992: 101): para Adálio é a infância, o tempo do pai e da mãe, das terras e dos animais. Essa aurora está no "sertão", que é o interior e no interior, "ligado ao ciclo do gado e com a permanência de costumes e tradições antigas" (Cascudo, 1984). O sertão de Euclides da Cunha (1998), ao mesmo tempo "sertão inóspito", "sertão adusto", "sertão - quase um deserto", "sempre evitado", "até hoje desconhecido, ainda o será por muito tempo", "o sertão de todo se impropriou à vida”, e “O sertão é um paraíso”, “o sertão é um vale fértil. É um pomar vastíssimo, sem dono". A duplicidade de chuvas e estiagens, de boa vida e inferno, a vida em mudança cíclica. Essa imagem do Sertão nos remete aos vários sentidos de sertão que nos apresenta Jerusa Pires Ferreira no seu texto "Um longe perto: Os segredos do sertão da terra" $(2004,30)$, especialmente, quando nos fala do "Sertão Inserto ou Exposto" explicando a conotação que tem a palavra sertão nos dicionários, que se junta a idéia de deserto e de povoado, de inexplicado, misteriosos, distante. O Sertão de Aurora ficou num tempo distante e se atualiza quando ele fala e lembra da sua vida em Aurora e quando começa sua canção aclamando a cidade de Aurora.

Nesse momento textual Adálio inscreve-se num tempo histórico, datado e linear, mesmo fazendo e impondo seu próprio labirinto temporal: "19 de abril de 1923” (42). Essa é a origem do eu no discurso historiográfico, exigida por ele para estar "no princípio". É esse tempo historiográfico que deforma, nas entrevistas (ao ser imposto pelo oralista "desde o começo" com perguntas e respostas, como se esse fosse realmente uma origem), os tempos íntimos, pessoais, narrativos, significativos do indivíduo, como ele armou sua vida enquanto dimensão de sua própria tessitura.

Mas esse tempo histórico é somente pontual. Ele não explica nada, diferente do logo em seguida “O meu pai não era muito pobre. Lá nós tinha gado, tinha muito animal!” (46), onde ele aproxima-se de onde queria chegar. Não somente informar, mas justificar, explicar, fundar sua vida presente e sua trajetória, sua oposição dentro da instituição (Santa Marcelina), a injustiça da sua longa miséria, sua desproteção e pobreza, sua perna cortada, seu corpo destroçado.

O pai tinha terra, gado e animal, "não era muito pobre". Isso quer dizer que, levando em consideração os arredores do seu sertão e sua própria vida depois, sem nada, que o pai era rico. Que ele era rico, tinha posses no seu "berço", de onde ele veio, não veio da lama. Não somente possuía gado (rebanho de boi e bode), mas também tinha animal, "cavalo, burro, jumento" (44), com certeza uma criação de galinhas soltas no terreiro dando ovos e carne, "nós tinha isso tudo" (45). Seus primeiros nove anos foram nessa vida de fazenda, entre o gado, junto dos animais, dentro do sentimento de posse, de diferença, do orgulho da terra, que ainda aparece vivo quase setenta anos 
depois, no seu texto. O mesmo orgulho da terra de Paulo Honório por "São Bernardo" (Ramos, 1992). Um Paulo Honório que se transformou em Fabiano e Sinhá Vitória sem os cacarecos, terminando como Baleia, sem o tiro, mas desprotegido e sem preás. Um "São Bernardo" que se transforma nos desertos de "Vidas Secas" (Ramos, 1982).

A primeira transformação, o primeiro revés: "Quando foi em 1932 houve uma estiagem" (49). A seca que reverte, alquimicamente, uma coisa em outra, um tipo de vida em outro, mostrando a precariedade daquele universo, ensinando a todos as mutações e as alterações da vida: nada é imóvel. Mesmo quem "não era muito pobre" tinha que se transformar ou perecer. E a família de Adálio se transforma de criadores de gado, de donos de terra, de ordenhadores e plantadores (de milho, de mandioca, de palma), do sertão para a zona da mata, em comerciantes numa cidade cujo nome é tão emblemático quanto Aurora: "Cascavel" (47). Aquele mundo da infância foi envenenado (a cobra no paraíso), aquela fonte secou, precisou mudar, mudar de vida e de cidade, mas não exatamente de classe social. Não se transformam a ponto de passar fome, de ser um JoãoNinguém, uma família perdida no mundo como a de Fabiano em "Vidas Secas".

Com a venda dos bichos, do gado e das terras, junto com as economias, a família vai viver de "uma bodega", "viver no comércio e com dois sítios de cana, um com alambique de cachaça" (48). Vai fazer e vender a "rapadura e a cachaça", feitas "no engenho lá de casa" (49). Vai vender "cachaça em grosso" (50), conviver com outro tipo de plantação (cana de açúcar), outra dimensão de plantio: "Tinha uns quatro quilômetros de cana” (51).

Aqui, em plena descrição da vida em Cascavel, a narrativa volta para um momento ainda em Aurora, quando ele vai para a escola paga pelo pai: "eu tava com nove anos, quando eu era menino meu pai botou nós pra aprende na escola" (52). Para ele, criado livre, a escola, ou o professor representa um horror, uma marca, uma ferradura, onde ele é ferrado junto com outros. E passados tantas décadas vem o sentimento inteiro numa descrição forte das primeiras impressões de uma criança com um tipo de ensino que pode ter mudado quanto ao castigo, mas que para a grande maioria, ainda é quase um adestramento.

Vamos ao painel: "lá com professor velho que sabia muito pouco [não ficamos sabendo se essa impressão é do tempo ou uma avaliação do tempo da entrevista: o professor sabia muito pouco], com distância de légua e meia, tinha que andar 9 quilômetros, de pés [ainda hoje milhares de alunos andam isso e às vezes mais para um estudo ralo e por vezes inútil!] pra chega lá pra pegar bolo, um carão! [tanto esforço para apanhar, tantas léguas para anteceder o bolo, o carão] Só bastava a pessoa errar uma besteira que pegava dois bolos! [a punição por nada, por uma besteira, um nada: dois bolos com a palmatória] Uma carranca mais feia do mundo [sem idéias, sem palavras, mas uma carranca feia, um monstro, um afugentador, como nas carrancas dos barcos]. E tinha menino fraco que se urinava [ele não era menino fraco, não se urinava nas 
calças, não tremia, agüentava, já era o herói que se jogará na "batalha da borracha": aqui ele se esquece, por um momento, da sua desgraça: a educação é feita para fazer menino se urinar nas calças: ele tem pena desses pobres que se urinam nas calças, fracos e pobres]. Eu acho muita graça quando lembro disso! [por que Adálio ri aqui quando lembra disso? Mais uma vez (17) ele acha graça em algo que é terrível: esse riso diz que ele não era esse menino, como não era aqueles cariocas que foram obrigados a voltar] Era uma bagunça e quando o camarada não dava a lição já viu, colocava ali uma tábua um bocado de caroço de milho e ele ficava de joelho em cima dos caroços de milho até segunda a ordem, só saía de lá quando ele desse ordem pra gente sair! [o clássico, feito na classe de aula, caroço de milho para os alunos se ajoelharem em cima: parece tortura de regimes militares ou coisa de Idade Média] $\mathbf{E}$ aí ficava ali aguardando [isso quer dizer que ele não se urinou nas calças mas se ajoelhou sobre os milhos]. A gente ia pra escola tudo já apavorado [a prisão, o asilo, a escola fazem parte foucaultianamente daqueles lugares de correção, de adestramento, de preparação] por medo do professor que era muito carrasco [o professor, o patrão, as irmãs, todos aqueles que punem o desvio têm de Adálio com um sentimento de repúdio]. Alguns choravam e aqueles mais fortes agüentava sem chorar [e mais uma vez o elogio aos mais fortes, os que agüentam sem chorar]" (56), assim temos uma primeira visão da escola, do professor, do ensino e suas punições. Uma iniciação à vida, "Um Começo de Vida", como o título de um livro de Balzac. Ali Adálio teve um ensaio da sua vida. Talvez isso seja a escola. E tudo bem pago: "Meu pai pagava a ele por esse luxo cinco mil réis por mês" (57).

Essa tortura minuciosamente descrita não era de graça nem era para se rir. O pai podia e pagava, achava que era importante o filho estudar e pagava. E não era somente para ele nem era barato. "Naquele tempo era réis! Ele tinha mais valor do que o real hoje em dia! Naquele tempo era o réis! $\mathrm{E}$ o meu pai pagava cinco mil réis por cada um de nós, porque nós era sete irmãos" (58). No total ele pagava trinta e cinco mil reis. Isso para mostrar o quanto era rico o pai, o quanto ele não é isso que se vê, que se sabe. Adálio vai construindo aqui, palavra a palavra, imagem a imagem, um "berço". Nesse momento sai de Aurora: "Eu vim terminar os meus estudos já em Cascavel" (59).

Viver a vida numa cidade, fora dos horizontes de serra, de mato, de plantação, de criação. Agora são ruas, praças, escolas, muita gente, outras obrigações, outras relações, novos sentimentos e obrigações. Vai para outra escola, "estudar já o primeiro livro" (57). E faz, num pequeno parágrafo, um reforço do que havia dito antes: "nos mudamos pra Cascavel e tudo mudou [o espírito do sertanejo, vendo sempre tudo mudar]. Porque em Aurora nós tinha gado, tinha cavalo, tinha burro, tinha muito animal! [o reforço proclamando a riqueza] Tinha umas 600 cabeças de gado! [com a dimensão do rebanho, que não é, ainda hoje, pequeno nem desprezível, mostrando que a fazendo do pai era maior do que ele mesmo havia apontado] Era uma fazenda no 
sertão! Aurora é o maior sertão do Ceará! De Aurora pra o mar de Fortaleza dá os 800 km, é longe! Eu gostava muito de Aurora, porque a gente nasce num canto, o lugar que a gente quer mais bem é ali [Aurora para Adálio significa o "paraíso perdido", aquele pelo qual ele vai sempre suspirar: ele é um "homem da terra", aquele que sofre sempre para conquistar uma e sofre desesperadamente quando perde esse lugar]. Mas menino não faz o que quer! [quem faz é Deus, o destino, o governo, o pai]" (58).

A passagem sobre o trem é memorável, principalmente num tempo, para uma geração inteira e num país onde os trens praticamente desapareceram: “Quando o meu pai tirou as passagens de trem (...) estranhei o negócio do trem, tive medo! (...) fiquei, e veio a família todinha. Fiquei pro homem vir me trazer em costas de animal (...). Nunca tinha andado de trem! Eu via ele passar assim lá longe! (...) Passava com aquela zuadona feia, medonha! Me assombrei! Com nove anos assim, caboclo do sertão é meio bravo. $\mathrm{E}$ eu achei que aquilo era um absurdo e eu tive medo! É engraçado contando isso agora!" (62). Um verdadeiro símbolo por mais de duzentos anos, substituto mecânico e moderno dos cavalos e mulas, das carroças, diligências e charretes, simplesmente desaparece, transformado, para nós, no metrô, que é, diante dos trens, soft (leve), clean (limpos), cult (cultuado), pós-modernos. O "medo" que os trens incutiam nas crianças e nos velhos, achando tudo aquilo um "absurdo", nos parece absurdo. O trem como um dragão correndo, soltando fumaça, rangendo, como se fosse nos engolir, é coisa de cinema, de literatura (na "A Besta Humana", de Zola, o trem é o personagem). É coisa feia (no Nordeste a frase "trem virado" significa mulher ou homem muito feio), para ter medo. Adálio não somente tem medo como foi compreendido nesse medo pela família. O pai, homem de posses, mandou um empregado levar o filho para a nova cidade. E recordando, no agora do dizer, ele acha uma piada esse sentimento, lembrando o quanto era "meio bravo", ou "brabo" (como eram tratados os nordestinos chegados na Amazônia), dizendo “É engraçado contando isso agora!". Depois de uma vida e todos os seus desatinos e travessias, a perspectiva e os sentimentos de uma criança pode parecer fora do contexto.

E na viagem com o arrieiro para Cascavel, o encontro com gente sem hospitalidade, que negam água: " $E$ deles que tinha água doce mas negava, porque a água era pouco, só dava pro consumo da família. (...) só vai passar ali aquela vez, e negava água pra nós, mas assim nós encontremos também gente boa" (63). Se negam água só pode ser gente má, mas ele sabe que também há "gente boa", porque do bem e do mal tudo é feito. O sertanejo aprende a conviver com a dualidade gritante de um mundo áspero e doce, violento e cordial, chuvoso e desértico, pobre e rico, desprotegido e senhorial.

Agora a outra vida, “em Cascavel (...) vida mudou! Porque lá em Aurora, nós tinha muito leite, a coalhada, o queijo!" (61). Do sertão para a zona da mata. Aqui o sertão é de fatura, 
de "muito leite, a coalhada, o queijo". Mas a zona da mata para onde a família vai, não é aquela de miséria, de escravidão, até hoje, com homens iguais a animais, pretos de fuligem, dentro dos canaviais, mas "Eram dois sítios grandes de cana, tinha o sítio do córrego e o sítio da bica. Um engenhozão alemão número 05 com três moenda e o alambique de cachaça, casa de engenho e os bois rodando dentro da casa" (65). Não é o mundo dos abandonados de Josué de Castro da "Geografia da Fome" ou aqueles seres destroçados de "Vida e Morte Severina" de João Cabral de Melo Neto, homens de lama e fuligem, mas a vida dos senhores de engenho, dos donos da cana, da cachaça, do álcool, do açúcar e dos homens. Entre a nota (62) e a (63) há uma descrição minuciosa de todo o preparo, concluindo com uma obviedade inesperada: "Quem fazia isso era os trabalhador!" (66): não eram os filhos nem os pais, mas os que trabalhavam para eles. Quem começa lendo o texto pensa se tratar de um miserável, um "despossuído", um "perdido de Deus", um pobre coitado que foi jogado no mato, mas o que se vai construindo é a história de um "filho de senhor", o "filho de alguém", um "fidalgo" nordestino no sentido de Ariano Suassuna, filho dos donos da terra, dos negócios, dos trabalhadores, de muitos destinos. É isso que Adálio vem, lentamente, construindo sem dizer, dizendo em fala mansa e amiga.

Quando ele diz "O meu pai vivia na bodega, no comércio, para trabalhar na cana tinha os trabalhador!" (67), ainda parece que o pai era um simples "bodegueiro", alguém que tinha somente uma vendinha. O texto inteiro diz e desdiz, aponta e nega, mostra e esconde, sendo cheio de dobradiças, lugares dúbios, inocências de culpado e culpas de inocente. Era rico, mas pobre, senhor de engenho e terras, mas bodegueiro. Parece trabalhador mas quem trabalhava eram "os trabalhador". Ele conhece como um trabalhador mas era o senhor, o senhorzinho. É tipicamente um discurso machadiano: "Por que bonita, se coxa? Por que coxa, se bonita?" (Assis, 1997). Quando ele diz "eu tangia os bois no engenho" (65) parece que era um trabalhador, um desgraçado que vivia tangendo os bois num engenho. Mas no mesmo parágrafo sai com uma confissão realmente machadiana: " $\mathbf{E}$ eu era tangendo os bois [o trabalhador, o pastor de bois, o servo, o ajudante], com uma vara com um prego na ponta [manejando um instrumento que causa dor]. Às vezes de malvadeza dava umas cutucadas nele [aparece o mal, a malvadeza, o ato, a ação perversa contra o animal], pra ele ajudar o outro porque tem gente que é escorão e boi também! [e a relação entre boi e gente: tem boi e tem gente "escorão", e os dois merecem a malvadeza, o esporão, a cutucada de vara com um prego na ponta]" (66). É a moral do senhor perdida por dentro das descrições, das experiências, das coisas, dos fatos, das mercadorias, das datas, das viagens, das opiniões. E nem aparece, nem parece. Quase não se repara. É, ainda, na "História do País", irreparável essa presença, essa ética, essa política do senhor no corpo, na alma, nas idéias de quase tudo e quase todos (Ribeiro, 1993). 
Morre o pai, tratado pelo melhor médico de Fortaleza, forte ainda, mas morre de uma doença (67). O pai desaparece, e surge a mãe em seus papéis tradicionais: "minha mãe ficou viúva, viúva de boa vida! Sempre naquele papel de mulher correta, de respeito e na companhia de oito filhos" (71). "Viúva de boa vida", e não poderia ser diferente. Era a mulher de um senhor, de alguém de muitas posses, mulher "Sempre naquele papel de mulher correta, de respeito" e na "companhia de oito filhos" para não ficar "falada". Mas a senhora nunca é o senhor e "ela ficou na luta dos sítios, lutando! Mas a mulher nunca é como homem e aí foi indo pra trás!" (72). Tudo foi "indo pra trás", dando para traz porque a mãe era mulher, que "nunca é como homem". E a culpa dos filhos muito bem analisada: "Quando dá fé o rapaz se formando rapaz não queria mais ir pro serviço outro pensando em casar, outros cantos pra sair e com pouco tempo o negócio foi fracassando" (73). Os filhos sem querer tratar das coisas da família, cada um para o seu lado, cuidando de si, seguindo seu caminho, e o "negócio foi fracassando". Os filhos do senhor com sua indiferença (criados para ter, não para manter e criar mais), e a mulher do senhor, por ser mulher puseram a perder o negócio da família.

E vem a longa descrição que parece ser uma coisa e é outra: "Mas [esse "mas" é significativo: deu tempo para o pai organizar os negócios] meu pai antes de morrer tinha comprado uma casa particular [eles agora tinham uma casa grande o suficiente para a grande família] porque esse negócio do sítio era sociedade. $\mathrm{E}$ o negócio foi fracassando e os filhos saindo [os filhos fugindo como ratos de um navio adernando, mas parece que o navio não estava assim tão arruinado]. Começou a vender a cana pra uma usina em Cascavel muito grande! [aqui não há nenhuma miséria, mas aumento de produtividade, de venda] Do Francisco Augusto de Deus. Não tava mais fazendo rapadura, nem mel, nem cachaça [sem esses produtos, mas não estava morta ou falida como parece o tom do texto] e saímos de lá e fomos pra essa casa que o meu pai comprou quando era vivo. Aí fiquemos lá nessa vida [parece uma vida desgraçada], fiquemos só com o sítio da bica [ao dizer que ficaram somente com esse sítio a impressão é de pobreza, mas a descrição adiante nega isso] mas não se fazia nada [esse não fazer nada não parece mudar a riqueza da descrição adiante], só cultivar a cana [era mais que o suficiente]. Muita plantação, muita fruta! Muita bananeira dando fruto e cajueiro muito! Coqueiro tinha demais! Tinha umas duzentas árvores de coqueiro e tudo carregava bem! [a descrição da abastança: não só o canavial, mas muitas frutas que com certeza iam para a feira, ou apodreceriam para nada] Agora vivíamos só daquilo [e a depreciação, falando como miseráveis abandonados à sorte, sem nada]. A cana era cortada e vendida a carga a cinco mil réis naquele tempo [riqueza que aparece logo depois de se lamentar da pobreza]. Era vendida pra usina: o camarada mandava cortar, pagava o cortador e se a pessoa quisesse que nós carregasse tinha uma tropa de trinta burro ["mandava cortar", "pagava" e "tinha uma tropa de trinta 
burros"]. Ainda houve uns lá dos meus irmãos que carregaram uns vinte e eles pagavam, assim mil e quinhentos por cada carro ao todo pagava o frete [o dinheiro, as mercadorias e a família tomando conta dos negócios e se dividindo, pois os irmãos partem para terem ou fazerem negócios à parte]. $\mathrm{E}$ assim foi indo, foi indo até que chegou um tempo que eu também me casei e foi quando veio esse desmantelo da guerra de 39 [o parágrafo inteiro é um jogo de temnão-tem, de esconde-esconde, rico-pobre-rico-pobre, terminando com a culpa final da grande dobradiça da sua vida que foi a guerra de 1939 e apontando para a próxima dobra no seu texto, que é sua mulher]" (74).

A sua primeira mulher, a mesma que ele se refere na música, é um ponto central e importante em sua vida e na sua narrativa, eles se conheceram nos arredores da escola que ela estudava e no momento em que ele narra quando a conheceu, demonstra a diferença de classe social que havia entre eles:Quando conheci minha mulher eu estudava num colégio chamado Rio Branco colégio particular e ela estudava no Grupo (75). Ela estudava num grupo escolar que formava professoras no quinto ano e ele num colégio particular, pago. Todo o relato de Adálio é demonstrando o quanto ele tinha alguma posse e se diferenciava dos demais! Que aquela situação de vida atual, do momento da nossa entrevista, era algo imprevisível, quase impossível de ter ocorrido se sua vida tivesse corrido normalmente e se uma guerra não tivesse interposto em seu caminho. Além de ser mais pobre que ele, sua futura mulher, só tinha mãe, pois o pai já havia falecido. Esse é um dado importante que a narração da entrevista traz e que se contrapõe com as informações que a sua canção aborda, pois é claro a narrativa do pedido de casamento, que ele faz ao pai da moça. $\mathrm{Na}$ canção, a família é completa, mas na entrevista, ele revela que sua mulher não tinha pai só tinha mãe (76), e que tinha sido a mãe dela que interessou-se em casar a filha dela com ele. E novamente a questão da guerra é retomada para mostrar o desvio da sua história.

Adálio já estava casado há uns seis meses, sua mulher estava grávida, quando foi convocado irremediavelmente para servir (77). Esse fato o afastou terminantemente da sua vida no nordeste e em família. Ele já estava há quase dois anos na Amazônia, quando teve condições de voltar e resolveu pedir notícias, foi aí então que ficou sabendo da morte da esposa e decidiu que não valia mais a pena voltar para o nordeste, mais uma vez fez sua escolha: "bem, agora a vaca foi pro brejo!” Não tenho mais nada a fazer, vou ficar por aqui mesmo! Porque eu não tinha porque voltar, casado ainda ia, podia adquirir alguma coisa, porque era casado no católico e civil, mas eu imaginei que quando chegasse lá não arrumava nada e assim eu me agüentei por aqui (79). Adálio explicou que somente após dois anos de trabalho no seringal é que se conseguia juntar algum dinheiro, pois o primeiro ano inteiro se trabalha para pagar ao patrão, os instrumentos de trabalho: Porque o primeiro ano o sujeito compra tigela de seringa, compra faca pra cortar seringa, compra um machado, compra fazenda pra fazer o saco. Aí vai abrir a colocação. 
Tudo caro! Naquele primeiro ano quando o sujeito é feliz e tem espírito de trabalhar, tem coragem de trabalhar ainda paga a contas. Agora no outro é que ele vai trabalhar pra ele! (78).

Essa dificuldade descrita por ele é o que na literatura sobre "A Batalha da Borracha" se chamou de "sistema de aviamento", um mecanismo usado pelos patrões dos seringais para prender o trabalhador por meio de uma dívida interminável. O trabalhador se endividava desde o momento em que era escolhido e embarcado para o seringal. Tudo era cobrado: mantimentos, ferramentas, tigelas, roupas, armas, munição, remédios. No fim da safra, a produção de borracha de cada seringueiro era abatida do valor de sua dívida, que normalmente era maior do que o valor de sua produção. E dívida rolava e crescia. Sem falar que as mercadorias eram vendidas nos Barracões dos Seringalistas por um valor quatro ou cinco vezes maior do que eram vendidos na cidade mais próxima, e sem falar na proibição absurda imposta aos seringueiros por seus patrões de comprarem em qualquer outro lugar. Proibição essa que era cumprida porque, basicamente, os trabalhadores não manuseavam notas, pois quase sempre continuavam devendo no barracão, e o que acontecia é que ia se dando baixa nas dívidas de acordo com o valor de sua produção.

Adálio vivenciou esse drama e esse aprisionamento por dois anos. Em muitas outras narrações de "ExSoldados da Borracha", essa mesma história é contada, cada um ao seu modo experienciou essa impossibilidade de retomo à suas terras- natal. No discurso de Adálio, esse fato é evidenciado para poder explicar os motivos que o levaram a se perder da sua familia no nordeste e se aventurar em terras amazônicas. É provável que se fosse possível retornar ao lugar de origem, não o reconheceriam mais, pois o que temos com sua narrativa é a lembrança de momento, que só existe enquanto contar. O impacto que esse des-locamento teve na sua vida é marcado na sua narração, a experiência de migrar reaparece a todo instante. $\mathrm{O}$ ir e vir da sua fala é entremeado por esse ponto crucial na sua vida: ter migrado para a região amazônica como Soldado da Borracha.. E o retomo, no caso de Adálio, é descartado pela falta de sentido, e por perceber, intuitivamente, que sua terra natal, sem sua esposa e sem a vida que ele tinha deixado, se tomaria irreconhecível. E ele aceitou o fato moderno e experiencial de quem migra de "nunca estar em casa”. Essa impossibilidade de retomo é bem expressa por Ian Chambers:

"Não podemos jamais ir para casa, voltar à cena primária enquanto momento esquecido de nosso começos e "autenticidade", pois há sempre algo no meio [between]. Não podemos retornar a uma unidade passada, pois só podemos conhecer o passado, a memória, o inconsciente através de seus efeitos, isto é, quando este é trazido para dentro da linguagem e de lá embarcamos numa (interminável) viagem” ( Chambers, 1990: 104)

E foi exatamente isso que Adálio fez quando começou a compor sua canção sobre sua história de vida , e foi também o que fizemos juntos ao constituirmos a narração de sua experiência a partir das entrevistas. Ele é muito claro ao falar sobre o porque e como compôs suas músicas, mais especificamente, “ A História de Um Nordestino na 
Amazônia”. Fez a música para não esquecer o que tinha passado. E ao transformar em linguagem manteve viva a experiência.

A diferença entre os dois mundos, o nordestino e o amazônico, é sentida e demonstrada durante toda a sua narração. O Nordeste representando esse lugar da memória impossível de se retomar e a Amazônia, como o novo lugar que não é a sua casa e que ainda por cima, vai lhe tirando tudo. A diferença entre os dois lugares se apresenta logo durante a viagem, através dos aspectos naturais e geográficos que Adálio observa: Quando fui vendo a Amazônia, porque eu não vinha do sertão, eu já vinha de dentro da praia de Cascavel, não é dentro do sertão! Mas nasci no sertão! Vinha da praia, da beira da praia e eu vim achando assim uma coisa muito diferente da nossa terra, umas árvores muito monstruosa! Muito grande! E um sistema todo diferente. (80) Adálio tem dois referenciais de origem: o sertão onde ele nasce e a beira da praia onde cresceu; nada se compara em termos naturais, à suntuosidade do mundo Amazônico. Naquele, tudo é árido, mesmo tendo o mar, e neste tudo abunda: árvores, águas, bichos, doenças, chuvas! E quando se chega no seringal tudo se intensifica: Quando chega no seringal aí é que a pessoa estranha! (81). O Sertão é o mundo que ele domina, e onde vê beleza, apesar de reconhecer que existe pobreza e que a vida é difícil e sofrida e cheio de donos e que aqui é uma terra de ninguém, lá não se pode mais ter sua própria terra e nesse momento da narrativa ele acrescenta um novo motivo para ter escolhido vir para a Amazônia cortar seringa, não somente para fugir da guerra na Europa, mas porque se pensava que na Amazônia seria mais fácil ter terra, vencer e poder retornar à terra natal: Lá a gente sabe que tem uma vida muito sofrida, vem pra cá que é um lugar que ainda ta tudo avulso, e quem quer um pedaço de terra vem pra cá, porque lá não tinha mais condições pra isso, mas lá não é ruim não! (82).

Mas logo no começo ele percebe que não é bem assim, que a terra suntuosa e as águas caudalosas têm dono, e o estranhamento migra do mundo natural para o mundo do trabalho, quando ele começa a descrever o cotidiano do seringal. Adálio na sua fala demonstra as formas de poder e as diferenças nas relações de trabalho, dos pastos e usinas de açúcar do nordeste para os seringais da Amazônia. No nordeste o poder é bem demarcado, mais claro, mais bem definido, o Patrão é reconhecido pela postura e pela roupa que usa, e demonstra todo pré-conceito de quem é estrangeiro num novo lugar: Eu trabalhei com um moreno lá no seringal só tinha muito era dinheiro, sem presença de tudo, era um cabra assim medonho! $\mathrm{E}$ assim a gente estranha tudo porque no nordeste o patrão é sempre o homem mais vistoso quem tem por ali, o mais bem trajado. Pra cá a pessoa ignora andar limpo! O patrão do seringal, um homem que dava mais 400, 500 tonelada de borracha andava com o pé no chão, roupa de mescla com um remendo aqui e outro acolá! Eu acho é graça nisso! Mas isso eu recebia com muita estranheza! Porque lá pra nós não existia isso não, lá o patrão sempre se distinguia do trabalhador, mas aqui é assim e isso tudo a gente estranha um pouco! (83) Mas o fato do 
patrão não se diferenciar dos demais trabalhadores, não amenizava a situação dura do homem que chegava do nordeste e ia se aventurar nos seringais amazônicos. E o primeiro adversário eram as doenças, e depois, o endividamento, sem falar na adaptação ao novo trabalho, que exigia toda uma técnica e conhecimento, desconhecida pelos “Brabos”. E também, a mata. Adálio conta do seu pavor diante de uma floresta que ele adjetivou como "terrível", "medonha" (84) e de como ele sentia medo dos barulhos desconhecidos e encobertos pela floresta: o esturro da onça, o berro da coruja. E ao assumir seu medo consegue retomar o discurso heróico: Eu via muito onça e matei muito! Matei Canguçu, matei Maçaroca e até Suçuarana, uma vez veio vindo uma meia amarela e eu matei! Agora o Canguçuzão, aquele pintadão, eu matei direto, eu matei até aquela acuada com cachorro. $O$ cachorro faz a cabocla subir, o caba chega já tá de cócora no zóio do pau, passou um dezesseis assim na goela e ela embola e joga pra lá! E a gente fica meio apavorado quando vê essas coisa.(85)

Um homem acostumado aos campos abertos, poucas árvores, onde se vislumbra o horizonte e alvoradas de pássaros e de abelhas, e ele acha isso de uma beleza sem igual, enquanto o grito desconhecido de um bicho dentro de uma mata onde ele nada reconhece, remete-o às explicações imaginárias do lugar, o piar de uma coruja vira o grito do Mapinguari [Dizem que o Mapinguari é um bicho que tem na mata, mas eu nunca vi. É um bicho doido, grande, selvagem! Tem o corpo de um homem, mas que bala não entra nele. E contavam isso e isso faz mais medo no pobre do seringueiro. Aí eu ouvia as corujas cantar, cada um canto mais feio do mundo! Grito mais feio do mundo! Aí eu disse: isso aí deve ser esse bicho! Eu não sabia que coruja daqui canta feio e dá um medo no mato. O camarada só sabe o que é hoje em dia, mas no meu tempo não sabia não. A gente chega novato, eles chamam bravo, ninguém sabia o que era aquilo! Eu só pensava que ia encontrar com esse bichos doido] (86), e mesmo achando graça da invenção popular, conto do povo, isso fica no seu "juízo". E nesse momento da narração ele chama todos os perigos e lendas que permeiam o universo imaginário da Amazônia: a onça, a serpente bico de jaca, o Cujubim, a cobra grande, o boto e nesse caminho ele saiu do espanto causado pela mata e foi para o espanto causado pelas águas.

Quando eu vi o rio Amazonas, o rio Madeira eu achei que dentro de uma água dessa é capaz de ter tudo que o povo inventa de ter, porque é água demais, é água demais! A pessoa se vê perdida no meio de tanta água. Quando a gente vem de Belém tem aquela baía do Rio Negro, que tucano não atravessa aquilo, a água é preta! Eu cheguei eu digo: “Ave Maria, isso aqui é um absurdo!, Que diabo é isso?!” Até que graças a Deus saiu de lá e cheguemos em Manaus, mas eu tava meio nervoso com tanta água, tanta água! A gente vê mato de um lado e do outro, mas se vê longe o horizonte assim fica um bocado puxado, 
Tucano não atravessa! Tucano meter a cara caí n’água, não atravessa ali não! $\mathrm{E}$ eu achei que era uma terra brejada de tanta água, e todas as histórias que o povo conta aí eu digo: “é capaz que seja verdade mesmo”. (87) Essa descrição do seu encontro com as águas da Amazônia remete-nos, inevitavelmente, a Bachelard (1989), que estabelece, no reino da imaginação, uma classificação das diversas imaginações materiais conforme elas se associam ao fogo, ao ar, à água ou à terra. No caso da água que Adálio nos apresenta, que imaginação material estaria associada a ela? A água aqui não se apresenta como fruição, mas como obstáculo, deixando tudo muito "puxado", difícil de se atravessar. Por ser muita água, esconde segredos e por ser muita pode mesmo abarcar todos os mitos e lendas da Amazônia. E não é à toa que as histórias mais contadas são a lenda do Boto e a da Cobra Grande, cujo cenário é sempre a água. É a água que os acolhem.

$\mathrm{Na}$ fala de Adálio fica claro aquilo que Teixeira (1999: 139) chamou de "visão mágica e ameaçadora que a natureza assume para homem", especialmente o homem de fora, que chega de outra paisagem e se depara com esse mundo misterioso, úmido e isolado. E como essas histórias populares, esses mitos amazônicos podem ser usados como reguladores do comportamento desse homem em relação ao lugar. $\mathrm{Na}$ sua narração, Adálio une bichos reais a bichos imaginários. $\mathrm{E}$ mesmo não acreditando muito nessas histórias que contam (isso eu não dou crença, não!), ele sente o impacto delas no seu cotidiano de trabalho na mata. $\mathrm{O}$ medo do desconhecido paira no seu imaginário e um simples piar de pássaro, barulho de galho, ou mesmo um evento corriqueiro, como se perder na mata, podem, momentaneamente, serem atribuídos e associados a esses mitos.

Via de regra, esses mitos tomam forma humana e suas ações afetam as comunidades dos homens. A lenda do Boto, que Adálio diz "que não dá crença", que ele não acredita muito, fala de um animal encantado que pode virar homem e voltar a ser boto, que gosta de festa e que é capaz de seduzir e fecundar mulheres (BEZERRA, 1985 p. 62). Já sobre a Cobra Grande (boiúna), a Cobra Honorato ou Norato, conta-se que uma índia engravidou da Boiúna e teve duas crianças: uma menina, que chamou de Maria e um menino chamado de Honorato. Para que ninguém soubesse da gravidez, a mãe tentou matar os recém-nascidos jogando-os no rio. Mas eles não morreram e nas águas foram se criando como cobras. Muitos acontecimentos "inexplicáveis", como desaparecimentos de pessoas e embarcações que naufragam nos rios, são atribuídas às ações da Cobra Grande.

E do espanto com as águas e os rios, com a mata e os bichos da floresta, ele navega e chega a mais um ponto de estranhamento e dor que o mundo amazônico lhe apresenta: a doença. Mas não é uma doença qualquer, a sua é uma doença historicamente estigmatizada, que carrega um campo simbólico inesgotável.

A hanseníase ou lepra, como é conhecida popularmente, foi, desde a antiguidade, (Le Goff, 1997)) uma doença envolta em tabus e crenças de natureza simbólica e cercada por um forte estigma 
(Claro,1995). Segundo Meihy “ Cada doença tem uma linguagem própria e gera um discurso sociosentimental único que interage na comunidade imediata refletindo as circunstâncias sociais e econômicas do grupo" (2006: 126). A lepra sempre foi a doença dos impuros, mais recentemente passou a ser a doença da pobreza, tanto que nos países ricos há muito tempo não existe. Maria Neira, diretora do Serviço de Prevenção e Luta pela Eliminação da Lepra, da OMS, disse em entrevista ao site da Organização Pan-Americana da Saúde, que a lepra tem atingido pessoas, principalmente na Índia, mas também no Brasil e em alguns países africanos, como Moçambique, Angola, Madagascar. O trabalho de História Oral realizado na Índia durante os anos de 1991 a 1993 (Kakar, 1995: 37/45), onde pessoas das próprias cidades onde o projeto foi implementado e, também, pacientes de lepra, ajudavam na identificação de novos casos e na conscientização sobre o tratamento e a cura da doença, mostra que mesmo depois de anos de campanhas de erradicação, a lepra ainda carrega o estigma do isolamento, do afastamento e da impureza. Entre os colaboradores do projeto de história oral desenvolvido na comunidade Santa Marcelina, local que Adálio residiu, e no qual o encontramos e realizamos suas entrevistas, a maneira como cada um recebe a notícia sobre a sua enfermidade dá a medida de como o discurso médico e o uso, que se disseminou como o nome "correto" da doença, quer amenizar o estigma da doença dos impuros e dos excluídos por Deus. As entrevistas realizadas com os Moradores da Comunidade Santa Marcelina, demonstraram que apesar dos avanços da medicina e do controle da hanseníase, a visão popular sobre a doença e sobre os doentes não mudou e não muda tão facilmente. Descobrir-se hanseniano ou com lepra é, para essas pessoas, um grande mal e um momento de modificações radicais e de perdas na sua vida. Com Adálio não foi diferente e ele é contumaz ao contar sobre quando ficou sabendo que estava doente: Quando eu soube o que tinha eu me achei perdido, bombardeado! Isso foi em 78, minha doença é dessa época. Eu achei que contraindo uma doença dessa, eu não sou mais homem pra nada! Porque do jeito que contavam o homem era destruído! Contavam que ía cai os braços, caí as pernas, e caí orelha, e caí beiço e cai tudo! Cada vez a pessoa ficava mais apavorada. (88). O estigma de que a lepra é uma doença que destrói o homem na sua própria carne se apresentou na narração de Adálio, e a perspectiva da incapacitação causada pela paralizia e perdas de membros do corpo, se aliou à impossibilidade de continuar a exerecer o papel social masculino para o qual ele acreditava ter sido criado e preparado: Meu medo era de ficar inutilizado sem poder trabalhar e caindo os dedos, e caindo um pedaço de um dedo, diziam que caia. Caía, mas já tinha passado esse tempo, agora não tava mais caindo não. (90)

E o que se seguiu no relato foi exatamente a destruição de uma vida, ou melhor, de um tipo de vida para outro. Essa mudança se deu por etapas: a primeira foi quando ele precisou passar nove meses na Comunidade Santa Marcelina para tratar a doença, era uma situação de exceção, ele ainda tinha sua casinha, sua terra, sua familia, mas já tinha tomado contato com um cotidiano de 
tratamento, estava na comunidade para se tratar, mas tinha para onde voltar e ainda podia ir e vir e até jogar futebol: Nesses nove meses que eu passei aqui era muito bom, era muito bom! A gente chegava aqui jogava até futebol, eu joguei aqui! Tinha um supermercado com muita mercadoria e eles tratavam muito bem as pessoa e o remédio era constante. Toda quinta feira Irmã Rosa, que era a chefe, ela ta há 23 anos de serviço aqui nessa comunidade, pegava uma Kombi, e mandava nós para Porto Velho. A Kombi levava e trazia. Nós íamos comprar alguma besteirinha, tudo era aposentado recebia aquela mixaria, ela pagava aqui mesmo, ninguém tirava no banco, ela quem tirava. Aqui nós tinha um cardápio, também, muito bom, assistência e muita visita. (89) Nessa etapa, Adálio estava internado no hospital e tinha pesadelos, com uma fera que queria agarrá-lo e ele queria gritar e não podia, queria falar e não podia, porque sua língua pesava, era um pesadelo recorrente, aconteceu muitas vezes (91). A doença era como uma fera tentando agarrá-lo, e sempre atrás querendo pegá-lo, ele queria gritar e não podia, queria se livrar da fera/doença e não podia, mas nesse momento ela não consegue alcançá-lo e ele está tratando de se desvencilhar, fazendo o tratamento no hospital da comunidade. Passados nove meses, parece que ele venceu a fera e consegue voltar: $\mathbf{E}$ o que é certo é que assim fui atravessando depois de nove meses fui embora, voltei pra minha casa lá no terreno. (92)

Nesse momento da sua narração, quando ele nos falou que voltou para sua casa no terreno, ele também voltou ao tempo do seringal, onde conheceu sua companheira, com a qual passou trinta anos. $\mathrm{O}$ ir e vir da sua narrativa, nos mostra que o tempo da memória não é linear, mas cíclico, vai e volta. Ele fez um corte entre uma estada e outra na comunidade Santa Marcelina, pra nos mostrar que ele teve uma experiência e uma trajetória que o levou até o momento em que gravamos sua entrevista. Um vida inteira no seringal onde ele tentou recompor a vida que deixou para traz no nordeste: Eu tinha uma companheira, morei com ela 30 anos! Quando conheci ela eu já estava aqui na Amazônia nesse tempo eu era sadio! Foi no seringal, numa festa de seringal, que em seringal tem muita festa! Começamos a namorar, a ter um xodó, mas eu fico muito envergonhado e acho muita graça contando essas coisas! (93). Quando Adálio começou a me contar sobre como tinha conhecido a sua nova companheira, começou a revelar uma outra história que não tinha sido cantada por ele na sua música. Ele casou novamente e quis constituir uma família, embora as razões que ele tenha dado para o casamento sejam machistas e digam respeito ao seu bem estar formal e não propriamente amoroso(96)., mostra também que ele tinha condições de ter uma esposa, tinha sua colocação, ou seja tinha um lugar no mundo, naquele mundo (94) E aqui ele traz para sua narração, um fato histórico para demarcar e situar o tempo em que isso tudo aconteceu na sua vida: Isso foi depois de 1954, nesse ano morreu Getúlio Vargas(95), para logo em seguida voltar para a intimidade da sua relação dizendo que sua nova mulher nunca pode constituir família, nunca pode ter filhos: Ela não constituiu família de jeito nenhum, não tinha filho de jeito 
nenhum!(97). Essa é a forma do "discurso" de Adálio, entremear sua fala intima, suas memórias pessoais com os fatos históricos, Como se com isso atribuísse um valor maior ao que ele estava contando.

E continua narrando sua história de vida que se desenvolve como uma sucessão de desgraças e de novas perdas. Sua nova mulher não podia gerar um filho, mas uma (vizão) deu a luz a uma criança e não podia tomar conta dela e eles criaram o menino como se fosse deles e para Adálio: Ser pai de uma criança é coisa de muito orgulho!” Aceitei de bom gosto e fiquei com o menino.(98). Mas esse momento de felicidade começa a se desfazer, quinze anos depois, seu filho de criação morreu afogado, um ano antes tinha ficado sabendo que estava doente. Tempos mais tarde perde a esposa e um ano após ao falecimento de sua esposa, descobre que a doença havia voltado e dá entrada pela segunda vez na Comunidade Santa Marcelina e aí ele perde a sua perna, amputada sem ele saber previamente. É uma seqüência de perdas fatais que o deixaram, como ele mesmo disse muitas vezes durante a narração, "arruinado"(99)

Essa etapa na vida de Adálio na Comunidade, é diferente da primeira. Agora ele não tem para quem voltar, não está em condições de tomar as rédeas da sua vida: É triste! Cortaram minha perna e eu fiquei aleijado. E agora fiquei aqui com um ordenadinho de cento e vinte reais e não tenho condição de sair daqui (100). Ele ainda tenta manter sua propriedade, mas começa a perceber que por não estar por perto, ela está se desvalorizando, assim como ele tem consciência da desvalorização do dinheiro que recebia e da impossibilidade de sair da Comunidade e se manter sozinho: Não saio daqui porque eu não tenho condição de sair. Quando eu vinha buscar meu dinheiro, pagava aquele motel com banheiro perto da rodoviária, a oito reais. Agora a pessoa ganhando cento e vinte reais, pagando durante dez dias dava oitenta e quando for pagar vinte dias dá cento e sessenta, como é que dá? Não dá de jeito nenhum, por isso eu estou por aqui.(101). E mais uma vez na sua fala, se coloca num patamar diferenciado, ao se comparar aos outros internos(103), que ele reconheceu estarem em situação bem pior do que a sua. Só resta para ele esperar uma prótese de sua perna para por no lugar, e apesar da Comunidade ser boa e as Irmãs competentes e atenciosas, ele ainda sonha em sair e ter novamente sua própria vida, sem estar vigiado, tendo uma vida liberta como sempre teve (102). Adálio se irrita com a situação, não aceita fácil a sua nova condição, mas é convencido pelas irmãs a ter paciência, agüentar um ano pra poder sair, era só o tempo de o chamarem para experimentar a prótese. E finaliza seu eixo narrativo com a frase vital de sua entrevista: A barra é pesada (104)

Dessa primeira parte da sua narração, que denominamos a Jornada, decorreram alguns aprofundamentos temáticos sugeridos por Adálio durante nossa conversa. Sua preocupação com o 
saber, com o estudo era evidente. Ele se sentia orgulhoso de estar conversando com pessoas da universidade, ligadas à história, e quis nos contar sua trajetória educacional. Nesse relato é impressionante a memória descritiva de Adálio com relação às cartilhas com as quais estudou, com o conteúdo ministrado durante as aulas. Ele lembrou de frases inteiras, poesias, conceitos e fatos históricos e foi narrando tudo ao falar da sua vida escolar 
A ESCOLA

Adálio começou a frequentar a escola formal com cinco anos de idade em Aurora: Em 1928 eu fui para uma escola [...] lá o meu professor chamava-se José Joaquim. Fui na capa de $\mathrm{ABC}$ e aprendi, que tava escrito na capa de $\mathrm{ABC}$ : “A preguiça é a chave da pobreza, quem não ouve conselho rara vez acerta, sem religião e sem justiça não há liberdade e o amor de Deus é o princípio da sabedoria". Tava escrito! (105), quando mudaram para Cascavel, mudou de escola e de professor, foi estudar com uma mulher, passou do reconhecimento das letras para a leitura e da leitura para escrita. É na escola que Adálio toma contato com a poesia e é muito especial que a poesia lembrada por ele na hora da narração seja "meus oito anos" de Casimiro de Abreu, o poeta da saudade (106), pois esse também foi o tema da sua composição principal, e ele vai repetir a frase "Ai que saudade da Aurora" e nos versos de Adálio, "aurora" representa o começo da vida, e também, sua Cidade de nascimento, na qual vivia em plenitude e onde, apesar das privações do lugar, sua vida e o seu corpo ainda eram inteiros.

E sai discorrendo sobre os conteúdos dos livros nas diversas disciplinas: aritmética, português, inglês, francês, história. Mas no meio disso, ele explicou que deixou de estudar aos dezessete anos, na verdade ele saiu da escola formal com essa idade e resolveu estudar sozinho, queria escrever, mas não qualquer assunto: Eu deixei de estudar, por minha conta mesmo eu comprei o secretário moderno, era rapaz novo, comprei aquele secretário dos amantes pra aprender assuntos delicados, pra escrever pra um namorada, uma moça que a gente simpatizava mas tinha pouco conhecimento com ela, e por meio de uma carta meio assim era capaz de a gente conseguir algo. (107)

Ele quer ser educado, mas não interessa essa educação formal de conteúdos, seu interesse é intimo, queria aprender sobre "assuntos delicados" e tinha claro o objetivo: a conquista amorosa. Mas Adálio não se alienou, e demonstrou consciência política, econômica e social do período que ele narrava. A mudança na moeda brasileira, de Getúlio Vargas até Fernando Henrique Cardoso, e através da desvalorização da moeda ele consegue mostrar a desvalorização da sua própria vida. (108)

Foi na escola também que Adálio aprendeu a se comportar frente aos mais velhos, conheceu a autoridade e descobriu que existiam os que mandam e os que eram mandados, e que tinham que obedecer. Sua mãe apareceu na narrativa desempenhado um papel de respeito e austeridade: A minha mãe era uma pernambucana que dava uma média de 95 quilos, então tinha a altura que dava um metro e oitenta, deixando assim a munheca num caboclo que nem eu! A peia cantava bonita! E na carta de $\mathrm{ABC}$ que eu tava estudando tinha escrito que "quem não ouve conselho rara vez acerta" e era mesmo se você num ligou, num prestou atenção entra na 
peia. E entrava mesmo!(109). A autoridade e a violência da palmatória deixaram em Adálio uma impressão de estranheza e de medo com relação a escola. E o medo de errar o perseguia e ele ficava nervoso.

Em sua narração Adálio contou sua dificuldade para aprender a ler e escrever, escrever não é somente dispor as letras no papel, mas tem a pontuação, onde por o ponto, onde por a vírgula e como isso afetará a leitura daquele texto: $\mathrm{Na}$ primeira vez que eu fui escrever pegaram na minha mão, botaram o lápis entre meus dedos, pegaram na minha mão e botaram em cima do papel e vai guiando a mão. Pega em cima da mão da gente, principalmente pra cobrir o rascunho aqui a gente faz a letra de tinta pra gente cobrir com lápis, a gente chama rascunho. $O$ translado também aquele que bota a escrita, as letras tudinho na frente da gente e a gente traz aquela letra pra cá pro papel, isso chama transladar, muita vez ele pegava na minha mão porque eu fazia aquelas letras e porque tinha a letra meia ruim, desengonçada, muita aberta, eu achava difícil levar a munheca pra ali e pra acolá, mas sempre quebrava um galho. E depois disso aí já era o ditado e a gente já tava mais adiantado, eu escrevia melhor! $\mathrm{E}$ agora ensinava os pontos, ah! Colocar os pontos que ali naquele ponto terminava a frase dando sentido e finalizando aquela frase. Perguntando, interrogando é a interrogação, agora admiração, se admirando, é exclamação de quem tá exclamando e assim vai e agora o ponto final sempre no meio da pauta. Começar na outra linha com letra maiúscula e assim era as explicações que eles davam pra gente assim, uma vírgula abaixa a voz, mas não pára, no ponto pára. (110) Ele tem noção de que a escrita não é simples e demonstrou lembrar das regras da boa escrita. Isso me levou a pensar nos motivos que fizeram Adálio preferir fazer suas músicas "na cabeça" do que escrevê-las, ele sempre associou o lembrar com algo que fica mais guardado se ficar somente na memória, na cabeça, como ele mesmo diz. Tanto é, que quando ele ainda não domina a leitura, ele lê em voz alta, ele expõe a fala, quando ele passa a dominar a leitura ele começa a ler calado: lia calado, todo livro que eu pegava eu lia comigo mesmo! Fosse mesmo obrigação ou se fosse do meu interesse mesmo pra ler, mas eu lia sempre! De repente passei a ler sem falar, só pra levar aquilo gravado na memória. Pelo menos assim a aritmética, a geografia que tem muitas perguntas e as respostas são complicadas, aí o camarada lia calado que era pra decorar! (111) E foi exatamente essa idéia que o levou a compor sua história para não esquecer das experiências vividas.

Quando Adálio começou a relatar os conteúdos que aprendera em história, foi interessante observar a operação que ele fazia entre os fatos contados pela história oficial e a sua própria história, aliás, essa é a tônica de toda sua narração. E sobre a História do Brasil, o que ele mais sabe e discorre com fluência é sobre os Governos Vargas. Ele gosta do perfil de Getúlio, apesar de desaprovar sua atitude em relação a Lampião: Até hoje eu só tenho raiva dele porque ele matou Lampião. 
Lampião pra mim era um homem honesto e começou aquela desavença ali em Pernambuco entre ele e aquela família dos Nogueiras. Os Nogueiras acabaram com a família de Lampião, escapou algum que não tava em casa. Lampião com toda nobreza se muniu com um rifle e um bornal de palha e matou os cabras que mataram o pai e a mãe, matou tudinho e ainda matou uns soldados e não quis se entregar. ganhou o mato! Para mim ele foi um herói, mas não era pra ser matado! Nunca ele fez nada no Ceará, ele era afilhado de Padre Cícero, fazia era encher a barriga daquele povo pobre.(112) Há no discurso de Adálio uma posição política definida, ele é de esquerda, acredita no poder popular e apesar de no Nordeste não ter sido um miserável, ao contrário disso, seu pai tinha terra, depois teve uma venda, estudaram, e como ele mesmo diz "tinham tudo do bom e do melhor", ele se identifica com as causas dos desfavorecidos. E isso se materializa na música que ele faz para o Lula, colocando toda sua crença num governo do povo e para o povo. Ao mesmo tempo sua fala atribui aos militares um papel civilizatório, eles conseguiram ligar as cidades ao mundo através do rádio, e povoar regiões distantes como a que ele se encontrava: Aqui mesmo tem Rolim de Moura, tem Costa Marques, tudo isso tem rádio. Isso aí só os militar mesmo, são os homens que não tem pena (103). E ele vai e volta pela história contando fatos aleatórios que ele acha relevante chamar atenção, e os fatos estão encabeçados por um autor, que normalmente é o Rei Dom João, Dom Pedro I, os militares, os presidentes, ou seja, um líder, um governante. E finalmente, chega ao contexto que o fez chegar onde chegou: a Segunda Guerra Mundial (104).

Nesse momento de sua narração, me perguntei quem era o historiador naquela conversa, pois ele lembrava de muito mais detalhes sobre a história da Segunda Guerra Mundial, do que eu podia me lembrar. Adálio se apropriou totalmente do discurso oficial da Guerra, que chegava através dos filmes sobre a Guerra e do rádio lá no Ceará: Isso tudo eu sei é porque eu tenho muita memória e assistia muito rádio, ia no cinema e muitas pessoas que tava no meio conversava também, e aquilo em mim fica gravado e no dia que precisa eu posso declamar que é assim. Eu não lia nada dessas coisas, mas eu via e ouvia, eu vivia. Via e ouvia mas em cinema. Eu vi bem umas três fitas da guerra e adepois muitas falas, pessoa fazendo comício ai explicando como era fácil de nós receber um ataque (105). Tudo isso fazia parte da Campanha pelo SEMTA ["que quer dizer Serviço Especial de Mobilização de Trabalho da Amazônia" (106)], órgão responsável pela organização da migração dos nordestinos flagelados da seca para o alistamento para a Amazônia. A projeção de filmes, as transmissões radiofônicas, um conjunto de imagens, especialmente os cartazes e pinturas produzidas pelo artista francês Jean Pierre Chabloz, e textos, eram utilizados como mecanismos de uma propaganda de mobilização que pintavam os horrores da guerra na Europa e construíam a idéia de uma Amazônia ideal, terra tropical, próspera, onde o trabalho e a água era encontrada em abundância, se contrapondo à terra seca do Ceará. 
Segundo Neves (2001: 114) "não foi por acaso que os retirantes eram alistados e preparados como soldados que iriam se deparar com uma "batalha" e que estavam envolvidos numa "guerra". O discurso bélico colaborava fortemente com a imposição de um conjunto de medidas drásticas aparentemente que se contrapunham radicalmente à realidade da seca." Mas no fim, o soldado foi esquecido e abandonado. E é esse abandono, dentre muitas outras situações, que Adálio denuncia contando sua história de vida.

Ele tem consciência do quanto sabe e lembra, e ele valoriza a formação que teve e compara a educação de hoje, com a que ele teve no passado: Por isso eu digo que os estudos antigamente a formação de pessoal era mais elevado (107), ele sabe que conhece coisas e sabe de assuntos que aqueles que estão à sua volta desconhecem, e sente-se um pouco melhor com isso. Durante toda sua narração, percebia uma vontade de dignidade que ele encontrava ao aliar sua experiência pessoal com as grandes narrativas da história, o tempo todo mostrou sua inserção nesse palco, por ter vivenciado uma experiência coletiva ou por ter conhecimento diferenciado daqueles que o rodeavam.

Além da Escola e desse conhecimento formal de assuntos escolares, Adálio mostra durante a sua narrativa uma sintonia com o mundo em que vive. Fala das dificuldades financeiras, conhece o valor do dinheiro e sua desvalorização com as mudanças de moeda, consegue participar da cena política, faz uma música para o Lula, percebe a difícil situação em que vive e a de seus companheiros na Comunidade. Essa sintonia que ele tem com o mundo, se deu, também, através do rádio ${ }^{22}$, que junto com seu violão e alguns poucos pertences, lhe acompanham até hoje.

\footnotetext{
${ }^{22}$ Ver Foto 14
} 


\section{OS SONHOS}

Outro tema que se desenvolveu, a partir da entrevista principal de Adálio, foi "os Sonhos", sonhos sonhados, e não sonhos de projeções futuras. Até nos sonhos a questão da migração se impõe como eixo principal da sua narração. O sonho com sua terra natal, e aqui retomamos o tema que nos é apresentado por Stuart Hall (2003), da impossibilidade do retorno: Eu sonhava direitinho que eu estava lá, mas que tinha um rio no meio, que nunca eu chegava na morada onde eu nasci, porque justamente o rio impedia de eu voltar pra lá. No sonho, eu nunca pude voltar porque tinha esse rio no meio! (108). Nem mesmo em sonho, Adálio conseguia retornar, e era um rio que o impedia, um rio concreto, um rio de espaço e tempo. Nos seus sonhos Adálio não realizava seus anseios pessoais, não conseguia voltar para Aurora completamente e nem podia tomar conta do lugar que tinha construído com tanto esforço, sonhava em poder volta, mas lhe cortaram as pernas, e em seus sonhos ele se deparava sempre com essa impossibilidade: Mas eu sonho continuadamente, as vezes o menos que sai é dois sonhos por semana, eu sonhando lá, inventando aquelas coisas, mas as vezes eu chego lá eu só vejo é campo e outras vezes eu vejo a fartura, coqueiro, mangueira, maracujeira, cupuaçu, graviola, esse limão grande por cima, muitas coisas que tem, eu vejo! Mas tem ocasião que eu vou e não vejo nada. $E$ às vezes tá trilhado de rastro de gado! E esse sonho é sempre, sempre, porque eu tenho muita saudade de lá. (109).

O sonho para Adálio é uma espécie de ilusão que se opõe ao pensamento, o pensamento é algo que você provoca e ele vem: Tem diferença entre pensamento e sonho! O pensamento é mais positivo, é mais positivo porque quando a gente bota o pensamento assim numa coisa é porque ou o sujeito tá cismando ou tem quer ter isso né? Já o sonho acontece sem nenhuma dessas idéias. (110) Para Adálio o sonho mais importante que teve na vida foi o que teve quando sua mulher já morta lhe apareceu no meio da mata, no sonho eles conversaram mais de uma hora, sua primeira mulher, aliás, sua mulher de verdade, pois durante a narração sobre sua vida deixou claro de quem ele era viúvo, foi um sonho importante porque mostrava que ela realmente estava morta e de alguma maneira o libertava para ele construir uma nova vida. E apesar de ter construído, jamais esqueceu a vida que tinha deixado para trás. 


\section{A MÚSICA}

A morte de sua mulher é ponto de partida para ele iniciar, quase dez anos depois, a composição da sua música e, também, para que ele decidisse não retornar para o Ceará e seguir em frente.

A música também é algo que Adálio vai ser obrigado a abandonar por conta da doença. Quando nos encontramos, ele já sentia dificuldade em dedilhar seu violão, e só lhe restava bater toada de repentista. Mas a sua experiência com repentes, cantigas e serenatas era antiga. A partir dos dezoito anos ele começou a tocar violão. Isso aconteceu tardiamente porque seu pai era muito rigoroso e não dava abertura para isso, só com a morte do pai é que ele se aventura nos ritmos do martelo e das serenatas: Eu comecei a tocar violão tava com 18 anos. Porque no tempo de meu pai não tinha liberdade pra isso, ele era um pouco duro não deixava ir para essas coisas, mas ele já tinha falecido.(112)

Quando ouvia sua música, ficava tentando enquadrá-la nos gêneros nordestinos: toada, repente, cantiga, martelo, mas é o próprio Adálio que explica o que ele faz: É uma história enversada! É assim que eu faço a rima: a gente bota num sentido como se deu desde o dia que eu pedi a moça em casamento, aí vai ajeitando, ajeitando! Faz o primeiro verso e daí pra frente vai se fazendo até quando termina tudo! Quando a gente vê já dá uma música. (111). Um história contada "em versos", é a história da sua vida que ele quer deixar decorado na cabeça. A Música para o Lula (113) foi uma homenagem a ele e é uma "canção de propaganda" para a segunda eleição do Lula, evocando as qualidades que ele enxergava naquele homem e diz muito das expectativas políticas que Adálio tinha. Em maio de 2005, quando nos encontramos pela última vez, ele ainda se mantinha esperançoso com o Governo do Lula, e dizia: pode não ta bom para os ricos, mas os pobres sentem a diferença". Somente esse tema valeria uma tese, mas aí seria preciso novas entrevistas onde ele pudesse falar mais sobre isso. E pudéssemos ver com o fim desse mandato as suas expectativas, decepções, enganos e esperanças.

Ele, na música do Lula, tem esperança num homem que é fiel, que respeita a todos independente da idade (113a) e dá o perfil do eleitor do lula: "Quem vota em Lula deseja/Vê um Brasil mais seguro/Não quer ver tantas pessoa /Passar fome no futuro” (113b). Ele, também, aponta os principais problemas sociais do país: "O Brasil tá com dívida externa/Inflação e carestia/Doente e pobre com fome/tem tanto que disse um dia/Seqüestrador seqüestrando/Ladrão rouba todo dia. (113c) e continua: "Além disso no Brasil/Tem muito pobre escravizado/Rico é sujeito à seqüestro/ O resto é discriminado/Esses pobres é mal/Com Lula vão ser só.” (113d) 
A questão da segurança pública; a fome, a pobreza e a doença; as questões econômicas: dívida externa, inflação, preços altos (carestia), são os temas que Adálio toca e que quer ver solucionado por um governo que ele acredita ser companheiro do povo e honesto, que vai restabelecer uma boa reputação (dos políticos) no país. E pede o voto de todos e declara o seu próprio voto garantindo que o Brasil, com Lula no Poder, deixará de andar para trás, proclamando o progresso. (113f)

Fico imaginando o que ele diria hoje, avaliando esses quatro anos de governo Lula (2002/2006), que música Adálio comporia? Como estaria seus sonhos e esperanças com relação ao país e ao Lula? Muitas questões ainda poderão ser levantadas, a partir desse corpus documental.

Os versos fazem o peito desabafar (114). E foi conversando sobre música que ele retomou o tema da doença e das limitações físicas que ela impunha: Agora tocar hoje é mais difícil por causa das minha mão, da doença!(115) A Lepra é uma doença traiçoeira segundo Adálio e para ele se apresentou da maneira menos popular, ao invés de manchas e insensibilidades, era um dormência que o acometia.(116) E ele vai demonstrando todo ressentimento de não ter vindo mais cedo se tratar. A lepra é uma doença da pobreza e da desinformação. Quando ficou sabendo da doença veio acompanhado de um senhor que pelo que ele contou, atrapalhou toda sua vida, informou ao médico que ele não tinha condições de fazer o tratamento em casa: Disse isso de ruim porque eu tinha meu sítio, muita plantação, muita macaxeira, muita galinha, carneiro, ovelha, tudo eu tinha lá. E ele queria ficar com o meu sítio com certeza, mas não teve jeito não, eu fiquei! (117). Esquecido pelo governo, traído pelos amigos e diante da situação em que se encontrava, arranjou na sua narrativa uma maneira de se recompor, querendo nos mostrar que toda essa sua situação, não era por conta da sua origem, mas uma peça do destino, pois sua família era limpa: A minha família era limpa, era uma família onde todos são sadio, são sadio, nunca houve doença nenhuma no pessoal. $O$ tempo que eu convivi com o meu pessoal, assim perto de 20 anos eu nunca vi uma pessoa nenhum tumor. O corpo limpo, sadio e quando não é limpo quer dizer que é doente. Tem o doente e o limpo! Eu quero dizer com isso que são um povo limpo, são uma gentona, bem branca. Eu era branco e corado, era branco e corado, agora hoje em dia eu tô desse jeito encardido. (118) E aqui ele atualiza o estigma da lepra como a doença do impuro, que escurece a pele, que dá dormência e que incapacita o homem. Ele não era assim encardido, pobre, sozinho, mas foi se tornando assim por conta da sua trajetória de vida. Esse não era o seu destino esperado e programado para as pessoas de sua origem, mas ele foi jogado nesse novo mundo por uma circunstância histórica e isso modificou radicalmente a sua existência. O poder da história oficial não é somente narrativo, mas é efetivo, se materializa nas vidas de pessoas como Adálio, e muitas vezes esses efeitos são fatais. Adálio nos mostrou com sua história de vida a maneira como ele se comportou, vivenciou, e sobreviveu nesse mar de histórias. A trajetória de vida de Adálio é 
igual a de muitos brasileiros, ele poderia estar ligado a várias comunidades de destinos: soldado da borracha, nordestino na Amazônia, hansenianos, velhos, migrantes! Escolher uma dessas comunidades seria aprisioná-lo numa única identidade possível. Escolhemos apresentar todas e mostrar a riqueza de caminhos que uma narrativa como essa possibilita. E nesse ponto, a história oral apresentou-se como possibilidade competente de trazer à tona, através da narração, a experiência vivida. O papel da história oral no mundo contemporâneo é devolver ao homem sua biografia. 


\section{III}

\section{PALAVRA CANTADA}

Antes de começar a análise da música, propriamente dita, preciso contar a minha experiência em campo com essa música de Adálio. Primeiro, o que me levou até Adálio foi o fato de ele cantar e tocar violão. A pessoa que nos apresentou, de imediato avisou que eu estava interessada em conhecê-lo, e um dos motivos era sua música. Conversamos muito, ouvimos ele tocar despretensiosamente sua música várias vezes, até que chegou o dia de gravarmos a música para o projeto. E ele fez como se estivesse num palco. Mas na verdade estava sentado em sua cama, no seu quarto, na Comunidade Santa Marcelina, o gravador em cima de uma mesinha que separava as duas camas existente no cômodo e onde ficava seu rádio e outros pertences. Eu estava sentada numa cadeira na sua frente e ele tocou e cantou sua história. Ele se emocionou muito, e como não podia ser diferente, eu também me emocionei e chorei. A história por si só é comovente, mas aquela cena, aquele homem mutilado pela doença e maltratado pela vida, ainda conseguia cantar e sorrir. Fui para casa achando que tinha uma missão maior do que simplesmente a pesquisa, tinha assumido um compromisso com o meu colaborador. Iniciei imediatamente a transcrição da música, e resolvi que iria produzir alguns livrinhos caseiros com a aquela história e iria presenteá-lo, ele poderia dar a sua história para quem ele achasse importante. Voltei com a sua música transcrita e levemente arrumada em versos, tinha dúvidas ainda sobre os cortes entre uma batida e outra, mas levei para que pudéssemos conferir, e a partir dali se iniciou uma relação efetiva de colaboração, foi minha primeira experiência de colaboração intensa e dedicada. Adálio me ouviu ler para ele sua história, e enquanto eu lia, ele ia me corrigindo, modificando palavras que eu não tinha entendido, e ele sorria muito do fato de eu não ter ouvido direito certas rimas, ria como uma criança. Depois dessa leitura feita com ele, voltei para casa, passei as correções e voltei com o texto em papel, para que ele pudesse ler sozinho agora e fizesse os últimos acertos, pois já havia lhe contado da idéia de fazer os livrinhos, fato que o deixou muito feliz e com grande expectativa. Deixei a música impressa e qual não foi minha surpresa de vê-la toda modificada, inclusive com um trecho novo, que não tinha sido cantado durante a gravação (essa parte eu coloquei, para efeito de apresentação na tese, em outra cor, para destacar). Ele me contou que pediu ajuda a Irmã Cláudia para escrever as suas alterações no exemplar que eu havia lhe entregue para a correção. Voltei para casa e passei mais uma vez as correções, dessa vez incluí o trecho novo e no nosso encontro seguinte, lhe presenteei com dez livrinhos, como se fosse um folheto de cordel, com o título da história e o seu nome na capa. O tempo passou e eu já estava em São Paulo cursando as disciplinas do doutorado quando meu orientador me alertou para a riqueza dessa experiência e sugeriu que eu percorresse o caminho dos dez livrinhos. Para quem ele tinha orfetado cada um deles? E qual as impressões das pessoas que os 
receberam? Mas quando voltei para Porto Velho, depois de um ano afastada, Adálio tinha conseguido uma prótese e tinha saído da Comunidade e naquele dia pelo menos, ninguém da comunidade sabia para onde ele tinha partido. Então me concentrei em encontrá-lo e me perdi dos livrinhos.

Tive sucesso na minha empreitada, encontrei-o alguns meses mais tarde, morando nos fundos de uma mercearia, em Candeias do Jamari, onde ele mora até hoje e vive sozinho, somente com a companhia do seu violão, e alguns poucos pertences. Perguntei sobre os livrinhos e ele disse que ainda tinha dois, mas que esses ele não queria dar não, que eram pra guardar de lembrança e que os outros ele não lembrava exatamente para quem tinha dado. Só lembrava do primeiro e do último: o primeiro foi para a Irmã Claudia, a mesma que o ajudou na correção e o último, para o dono da mercearia que lhe alugava a casa dos fundos. Em agosto de 2005, nos vimos pela última vez. Pretendo, no meu retorno visitá-lo para entregar-lhe a minha tese e para conversarmos sobre a vida.

Nesta parte do trabalho me proponho a analisar os temas cantados por Adálio em sua "história enversada", sempre tendo em vista a sua palavra contada. Sabemos que numa entrevista os temas, dúvidas e questões que surgem podem ser aprofundados e discutidos, mas na música, as escolhas são mais nítidas, mais demarcadas. Para mim a música sobre sua vida dá pistas de como Adálio se pensava e como ele gostaria de ser lembrado, ou que ele gostaria de lembrar de toda sua experiência de vida. A própria escolha do ritmo já indica seu lugar de enunciação: "tem a batida de um repente a sua história enversada". Sua palavra cantada se inscreve num contexto nordestino, onde a poesia popular é arma de protesto. Mas diferente dos grandes cordelistas, Adálio não conta "a história dos homens famosos da região, os acontecimentos maiores, as aventuras e caçadas e de derrubadas de touros, enfrentando adversários"(Cascudo, 1954:237), conta sua própria (des) aventura, sua própria jornada. Na poética de Adálio a matéria-prima de escrever é o seu amor vivido em Cascavel e interrompido, bruscamente, pela segunda guerra mundial. Seu intuito é claro, cantar para não esquecer e como ele já tinha dito antes, guardar na cabeça, é o melhor jeito de não esquecer.

Ele começa pedindo sua música pedindo licença para contar sua história, isso pressupõe um lugar para se cantar, que ele acredita ser honrado e o povo presente merecedor de ouvir sua história. Ele saúda aqueles que vão ouvi-lo.

Ao senhor dono da casa

Peço autorização

Para contar-lhe uma história

No seu honrado salão

Para esse povo presente 
Vai a minha saudação.(1)

Esse salão tem um senhor que autoriza a sua fala, que lhe concede a fala, na entrevista, ele também pergunta: “ posso falar, sobre o que eu quiser? Sou eu mesmo que vou falar? As duas narrativas mostram a necessidade que Adálio tinha em contar sua história. E ele segue explicando do que se trata a sua história e se identifica, diz quem ele é: Sua história é sobre uma mágoa, a sua mágoa de viúvo, ex-soldado da borracha (2). Nesse instante da música ele diz quem é, quais as identidades que o formam. Na palavra cantada o ser viúvo predomina e na palavra contada o ser exsoldado da borracha é mais presente. Ele descartou várias outras personas, ele não estava cantando a mágoa de um hanseniano, por exemplo.

E segue dizendo de onde veio, falando da sua origem. Na palavra cantada a história é linear, dizer onde nasceu, onde se criou, que tinha pai e que tinha mãe(3), remete a um tipo de contar, já sua narrativa da entrevista carrega mais marcadamente as marcas do oral, do ir e vir do pensamento. Nesta estrofe ele, também, aponta o tipo de criação que teve, o fato de ter pai e ter mãe, demonstram que ele não foi criado solto no mundo e sem amor, e que embora ele tenha sido abandonado, e que esteja sozinho na velhice, houve um tempo em que não foi assim, pois ele amou e foi amado. Sua relação familiar na música é tocada de leve, mas na sua entrevista ele discorre sobre as desavenças com os irmãos a ponto de ele não querer mais retornar para casa, a austeridade do pai e mão firme da mãe.

Dá infância ele salta para a mocidade, ele era um sedutor, cantava em serenatas e tinha xodó com mulheres, e não tinha compromisso com ninguém. Nesse ponto as narrativas se encaixam e se complementam. Adálio nos conta que parou de estudar formalmente, mas que tinha interesse pela arte da conquista e queria aprender a escrever bem para fazer cartas de amor para suas conquistas(4). Até que ele se apaixona. Como toda boa história de sedutores, ele não é de ninguém, não se compromete com ninguém, até que encontra o amor da sua vida, sua alma gêmea, sua carametade(5). A sua matéria aqui é o amor romântico.

No momento em que vai falar do seu amor para sua amada ele se coloca inferior a ela, ainda dentro de um jogo de sedução e conquista, ele a pede em casamento, se reconhece pouco merecedor, mas que se ela o aceitar, ele será: O mais feliz dos amantes (6). E ela entra no jogo, levanta-o da sua inferioridade, narrando suas qualidades e dizendo que ele tem competência demais (7) para tomar conta dela e pede que ele fale urgente com seus pais, pois ele já mora em seu coração. (8). Nesse ponto temos um conflito interessante, entre a palavra cantada e a palavra contada: na música, a sua noiva tem pai e mãe, na entrevista, ela só tem mãe e Adálio se mostra como uma saída interessante para aquela sua filha. Ele não era rico, mas sua família tinha algumas posses, ele tinha condições de sustentar uma família. Adálio percebe que a moça está louca de paixão 
e é preciso se apressar para o casamento sair logo (10). E ele vai na casa da sua noiva, pedir ao pai da moça, sua mão em casamento, e pede de modo distinto e direto ao pai (11), mas com a elegância de um sedutor, pede também a opinião da mãe da noiva(12). E segue descrevendo suas qualidades: é solteiro, não possui vício, tem casa, cama e mesa, ou seja, pode prover um lar e além de todas as condições materiais ele tem muito amor para dar.(13). E numa situação inusitada, a moça é chamada para saber se aceitava o casamento, o seu pai pergunta se ela "Quer casar com esse moço?"(14). $\mathrm{Na}$ palavra contada, Adálio não é tão detalhista em contar o pedido de casamento, fato que esmiuçado na palavra cantada são dez estrofes destinadas ao pedido e as opiniões do pai, da mãe, da noiva e dele mesmo. (10 à 20). E o Pai da noiva, ao exigir um casamento rápido (21), ajuda Adálio no seu desejo De fechar nossa amizade (22) e iniciar o casamento. Da estrofe ( 23 a 26), ele conta do casamento, da festa, da troca das alianças, dos presentes, até chegar na lua de mel. Os detalhes narrados na música não são nem mesmo mencionados na entrevista. Na palavra contada o que se marca é a tragédia da separação. Apesar de ele cantar dizendo que uma passagem como aquela ele jamais esquecerá, pois foi a realização de um desejo, dormiu abraçado e beijando a sua mulher querida(27). E ele teve o momento supremo da sua felicidade quando a sua mulher ficou grávida e soube que $\mathbf{O}$ fruto de um amor puro (28) iria nascer.

E a partir da estrofe 30 a narrativa se modifica de amor romântico para a narrativa de uma tragédia. Esse é um limiar, sua vida se modifica por algo externo à vida simples que eles levavam e ele reconhece o despropósito daquilo tudo:

Porém a coisa mudou

E eu não tive a satisfação

De ver o meu filho nascer

Por causa do alemão

Que desfechou uma guerra

Mundial sem precisão.(30)

O momento da mudança em sua vida aparece como um rompimento com uma vida feliz e se com uma vida provações. Esse é o momento da escolha que vai mudar seu destino: Ele é convocado para $\mathbf{O}$ exército Brasileiro/ Pra guerra no estrangeiro (31). Ele não aceita muito tranquilamente o fato de lutar no estrangeiro, na música a explicação que ele dá é que ele até lutaria para defender sua Pátria, mas para defender a Pátria do outro, em terras alheias, ele não acha conveniente. Adálio tem a nítida consciência de que essa não é uma guerra da sua Pátria e resiste.(32) E se alegra com a notícia que recebe, através de um comandante:

Depois disso uns oito dias 
Lá só se falava em morte

Quando um comandante disse:

"Os recrutas tão de sorte

Vão pra guerra da borracha

Riscar seringa do Norte”. (33)

$\mathrm{Na}$ música Adálio dá razões mais heróicas por não querer ir para guerra, mas na entrevista diz claramente que tinha medo e que preferiu vir para a Amazônia para fugir da Guerra. Na música ele não fala em medo explicitamente, mas coloca a situação da guerra como um "caso tenebroso" e provoca dizendo que Quem diz que vai pra guerra satisfeito é mentiroso (34). Ele pode até ter medo, mas mentir ele não mente. Da estrofe (35 a 40) ele descreve a sua despedida, sua mãe, pois sei pai já havia falecido, sua tia, seus irmãos e sua esposa, desolada com sua "sorte mavalda", e daí por diante sua sorte muda, e o que era alegria e esperança vira tristeza e saudade.

E agora Adálio empresta de Casimiro de Abreu, referência que ele tinha, do seu tempo de escola, para falar da saudade que tem de Aurora, e tudo que ela representa, não somente a aurora da sua vida, mas o lugar da memória:

Que saudade eu tenho de Aurora

Minha cidade natal

Do meu Ceará querido

Lá deixei meu natural

Pra defender certamente

O torrão nacional (41)

Aqui ele dá um sentido todo especial à sua vida, ele deixa tudo pra defender algo que não é somente dele, mas é coletivo, de todos, “O torrão nacional”. E assim tanto na palavra cantada quanto na contada ele dá um sentido maior a sua jornada, tornando-a a jornada de um grupo, de uma comunidade maior: a dos soldados da borracha. Ele se sacrifica, todos os soldados da borracha se sacrificaram: trocaram a vida livre do nordeste, apesar da seca, para uma vida de escravo no norte, apesar da abundância. Nesse aspecto as duas narrativas se equivalem, se complementam, se encaixam.

Agora sua matéria prima poética é a denuncia e a descrição da vida nos seringais da Amazônia e de cara, mostra o sistema de endividamento, ao qual o nordestino recém chegado era submetido (43 44 e 45). Na palavra contada, Adálio aprofunda essas relações entre os novos seringueiros e seus patrões. Além das dificuldades do trabalho, aparece, também, na palavra cantada as dificuldades encontradas na natureza, com as novas doenças e com o fato de viver sozinho, sem 
ter ninguém que pudesse tomar conta dele $(46,47$ e 48$)$ e mesmo sofrendo muito, ele consegue se adaptar ao lugar, de certa forma, ele mostra que conseguiu vencer na medida do possível (49). E aí uma nova possibilidade se apresenta, da mesma maneira que ele conta na entrevista, com dois anos que estava trabalhando nos seringais, paga sua dívida e consegue juntar algum dinheiro para poder voltar à sua terra (50), é quando ele escreve uma carta para sua esposa, pedindo notícias e falando sobre sua vida, indicando que gostaria de retornar para casa, e Adálio canta uma linda carta de amor, onde afloram sentimentos, dores, angústias. Nessa carta ele se abre ao subjetivo e deixa de lado os fatos históricos, tão valorizados na palavra contada. É uma declaração de amor em treze estrofes (51 a 63), e aí ele recebe uma carta de volta (64,65 e 66) contando da morte de seu filho e da sua esposa, retirando dele qualquer esperança de retorno e jogando-o no mundo Amazônico definitivamente, abandonado pelo governo, esquecido pela história e sem família. Um fato interessante, é que na palavra contada Adálio afirma que a carta foi enviada por sua tia e na música a emitente da carta é sua sogra, conversamos sobre isso e ele me falou: a música é que está certa.

E vai nos versos seguintes contando da dor da saudade, da solidariedade dos amigos no seringal quando soube da morte da sua mulher e termina dizendo que levará as lembranças da esposa para eternidade (74) e finaliza dando sentido a sua música, que mais do que simplesmente para contar uma história, é o remédio indicado para tirar mágoa e aplacar a dor de um viúvo apaixonado (76).

Depois de tantos anos, Adálio ainda se sente um viúvo apaixonado, essa é a sua identificação mais marcante, primeiro porque sua viuvez se refere apenas a sua primeira mulher, e é somente dela que ele fala na sua "história enversada". Não entram como tema da música, nem seu segundo casamento, seu filho adotado, nem a sua doença. Esses silêncios ou esquecimentos notados na música, definem a história que Adálio quer que seja lembrada. Essa ausência não é "má fé", mas escolhas da memória que qualificam sua imaginação e o faz o dono da sua criação narrativa. Mediar essa criação, foi um processo que passou de saboroso a doloroso e de doloroso a saboroso, muitas vezes. 


\section{A PALAVRA CONTADA E A PALAVRA CANTADA UMA CONCLUSÃO POSSÍVEL}

Ao encerrar a leitura da narrativa de Adálio, percebi o quanto é difícil abrir mão dos conteúdos e conhecimento formais que abarquei durante esses anos de leitura e vida acadêmica. A sua experiência de vida e a sua memória construída durante a entrevista são prenhes de sentidos próprios. O que fiz na minha leitura foi atribuir um sentido para mim. Emprestei um significado meu para sua história de vida. Fiz referências e ligações com autores, imagens e sensações que me levaram a perceber o quanto podem ser ricas essas narrativas de pessoas "comuns". Adálio se tornou para mim um autor com quem pude dialogar sobre diversos assuntos. Essa "autoria" de Adálio só se tornou possível devido ao papel que ele desempenhou no momento da entrevista e na construção da sua narrativa. Sua colaboração efetiva transformou sua "história não contada" (Portelli, 2001 :13) em história oral. Sua experiência materializou-se numa narrativa que pode ser manuseada e lida da maneira que o leitor aprouver. Poderíamos aqui ter um impasse no conceito de colaboração, se não estivesse bem nítido os momentos de autoria, mediação e colaboração de cada um dos participantes desse processo: colaborador, oralista e possíveis leitores. Já foi estabelecido que o processo todo é transcriativo, e para mim, depois desse trabalho, divide-se em dois momentos bem nítidos: o da construção da narrativa e o da leitura e interpretação da narrativa. É no momento da construção da narrativa que a colaboração e a mediação fazem-se presentes de modo imperativo.

Durante a entrevista e na passagem do oral para o escrito devemos privilegiar o colaborador, sua fala, seu jeito de dizer. No segundo momento temos a interpretação/análise das narrativas, que pode ou não acontecer, dependendo do projeto. Nesse caso especifico, trato dos projetos ligados à Academia, que exigem do oralista a análise, ou seja, seu posicionamento frente às narrativas. É claro que durante a análise, não podemos perder de vista a colaboração, mas temos uma tarefa acadêmica, que devemos exercer com o devido respeito ao colaborador e a sua história narrada. Sem cair nas explicações ocas e nas conclusões óbvias, ou simplesmente repetir de modo diferente a mesma história contada pelo colaborador. Esse ainda continua sendo o desafio da história oral que se pretende autônoma e que era também o desafio desse trabalho, que considero não cumprido, ou mesmo falho e incompleto. Talvez a questão aqui seja mediar conhecimentos e saberes e na interpretação a partir da percepção dada pelos colaboradores, construir um saber, com isso não estaremos abrindo mão de um conflito, e muito menos neutralizando o nosso papel de mediação, mas tornando-o político na medida em que nos tornaremos fomentadores de novos argumentos históricos.

Aqui, temos uma primeira formulação a partir desse trabalho do status dessa história oral que defendo, talvez sua autonomia não se dê na transformação da história oral em disciplina 
acadêmica curricular e por isso mesmo presa aos rituais e costumes acadêmicos. Mas sua autonomia está no fato dela ser uma importante e rigorosa maneira de diagnosticar as questões do presente. Ela não é uma disciplina, porque, provavelmente, ela não precise ser mesmo, para poder transitar nos muitos espaços: academia, escola, partidos políticos, agremiações, associações de bairros e outros espaços da sociedade. A História Oral é instrumento político, muitas vezes prático, que gera políticas públicas, mudanças sociais e outras vezes atua no nível da conscientização da trajetória das pessoas, dando uma dimensão nova para suas vidas. Esses modos de atuação não são excludentes, mas ao contrário, se complementam, potencializando o caráter público e político da história oral.

Por isso a importância de se privilegiar a narrativa integral, de se publicar as histórias de vida em trabalhos de história oral.

Com relação a Adálio e suas narrativas, percebi que sua experiência gera nitidamente duas memórias: uma contada e outra cantada. Cada uma fala para a outra sobre o vivido e sobre como se deve lembrar esse vivido. Elas são complementares e em cada uma delas Adálio tem uma performance $^{23}$. Performance "como instante em que o passado e o presente se encontram, em que reúnem os eixos paradigmáticos e sintagmáticos, em que a memória se projeta na transmissão, implicando em energia corporal, em sentido, em gesto" (Ferreira, 1997:60). Como devolver esse conjunto performático que tivemos no momento das entrevistas, onde reproduzimos uma audição, seja no caso da palavra contada ou no da cantada? Para mim é a Transcriação que devolve ao texto escrito a perfomance, na medida em que busca assimilar na escrita, o gestual, os olhares, as demonstrações de emoção, de maneira teatralizada. Lendo a narrativa de Adálio evoco a lembrança de um quarto ensolarado, numa comunidade de hansenianos, numa cidade amazônica, na qual o conheci. Seus olhos expressivos, vivos e cheio de vontade de contar sua história. Às vezes parecia tímido, às vezes revoltado, indignado e sem esperança. Sua voz, seu sorriso, o modo como esfregava as mãos uma na outra enquanto falava e, também, como batia nas pernas ao sorrir envergonhado, formam junto com o seu texto o Adálio que ele quis apresentar. Adálio é, portanto, poeta, personagem, pessoa, persona e pivô (Ferreira, 1997/1999): um detonador de histórias, que ao narrar sua própria experiência de maneiras diferentes possibilitou que pudéssemos pensar nas muitas histórias não contadas e silenciadas de pessoas iguais a ele. Sua narrativa se referenciando na história e nos grupos sociais com os quais ele se identifica, promoveu a interação entre a história de vida e as trajetórias coletivas.

A memória da sua palavra contada não é linear, é detalhista, não esconde a doença, a vida na comunidade, o seu segundo casamento, a morte do seu filho adotado. Delineia seus sonhos e o mostra ainda combativo. Na palavra contada, temos um nordestino, ex-soldado da borracha, que

\footnotetext{
${ }^{23}$ A performance, segundo Zunthor (2000:34-35), é sempre constitutiva da forma, mas ele nos ensina a voltar a ver o conjunto, a reintegrar o texto ao conjunto da obra performatizada, que se compõe de tempo, lugar, finalidade da transmissão, a ação do locutor e a recepção do público.
} 
conhece e se insere na história do Brasil, que evoca os fatos históricos para explicar e justificar sua situação de vida. Marca sua experiência pela experiência coletiva. Parte do eu para o nós de uma maneira ímpar, como se soubesse que sua história só faria sentido se colada a uma história comunitária. Primeiro, os nordestinos que vão para a Amazônia como soldados da borracha; em seguida, os seringueiros e o cotidiano no seringal; depois, os hansenianos e a comunidade Santa Marcelina. É como se ele estivesse nos dando as redes que o explicaria. Não é à toa que ele foi o detonador de dois projetos de pesquisa: A Cidade dos Excluídos e Nordestinos na Amazônia, que ao todo geraram mais de 50 colaboradores $^{24}$. Mas é interessante que essa apropriação do público não se dê no modelo heróico tradicional do qual nos alerta Portelli:

“No âmago da narrativa criada pela clássica entrevista de história oral e pelo seu clássico texto, encontramos motivos e temas que insistem no relacionamento do individual e do público. Por exemplo, narradores em qualquer parte saboreiam narrativas de "enfrentar o grande homem", anedotas teatrais de confrontos pessoais com figuras de autoridade institucional na qual trabalhadores enfrentam chefes (especialmente em casos de negociações sindicais): a tropa, os líderes, os estudantes, os professores, os soldados, os oficiais, em representações de coragem, orgulho profissional, resistência política.” (2001:15)

Ao contrário, Adálio está o tempo inteiro mostrando que é apenas um sobrevivente, dessa história cruel de abandono e solidão. Ele veio obrigado, aprendeu a lidar com seringa a duras penas, assumiu seus medos e suas angústias, e não se sentiu um "herói da pátria". Isso evidencia ainda mais a diferença entre essa "clássica entrevista de história oral" e a entrevista que fazemos nessa "outra história oral”. Veja que nós não encobrimos a relação entre o individual e o público, mas ela se deu na medida em que o colaborador quis colocar. E esse aspecto é relevante na maneira como entrevistamos as pessoas e estabelecemos a colaboração. É Portelli, também, que alerta sobre o fato de que ao iniciarmos a entrevista definimos os papéis e estabelecemos a base da autoridade narrativa. E para essa "outra história oral", é importante que no momento da entrevista a autoridade e a decisão do que e como falar esteja com o colaborador.

É claro que o que apresentamos aqui é resultado de uma negociação de agendas: a minha, que tinha interesse em sua história de vida e a de Adálio que se interessou por contá-la. Mas sua pergunta inicial, assim que soube que gostaria de entrevistá-lo foi: "Vou poder falar o que quiser? Qualquer coisa?”. Essa pergunta me fez pensar sobre minhas intenções e me lembrei mais uma vez de Portelli (2001), que diz que “ para um profissional de história oral, uma entrevista é sempre uma lição de aprendizagem" e de Woldenberg (1992), quando conta a reação de um entrevistado quando perguntado pela pesquisadora sobre questões históricas mais do que batidas: - se queres saber sobre esses assuntos vai aos livros e à biblioteca, pensei que falaria sobre o mar ou coisas do gênero. Então

\footnotetext{
${ }^{24}$ No projeto a Cidade dos Excluídos foram realizadas 17 entrevistas e no Projeto Nordestinos na Amazônia 42 entrevistas.
} 
me propus a ouvir o que ele tinha a dizer e fui pouco a pouco me colocando e aprofundando as questões que me chamavam atenção.

Adálio tem consciência do processo pelo qual foi submetido, ele aceita a colaboração, sabe que sua história será base para um estudo, se esmera em contá-la, mas a sua palavra contada não é uma plataforma política, ele sabe disso. É quase um deleite pessoal, não tem função social clara. Não é uma fala de protesto e de denúncia.

Para a palavra cantada, Adálio atribui um sentido: “Cantar para não esquecer”. Isso explica a forma musical escolhida: $\mathrm{O}$ repente. Gênero tipicamente nordestino, que remete às suas raízes e que por definição está ligado à memória e à tradição oral. Na palavra cantada ele se auto define: um nordestino na Amazônia e um viúvo apaixonado. Mas Adálio mais uma vez subverte o gênero, ou melhor, se utiliza de uma forma para comunicar o que quer. Não se molda. Conta sua jornada de anti-herói e não se importa em mostrar fraqueza. E aí começo achar que seu método em evidenciar suas falhas, faltas e medos, é o que lhe garante autenticidade narrativa. Inicialmente pensei que ao não falar na doença e na segunda mulher e filho, ele estaria escondendo, omitindo fatos contados na narrativa. Mas não, não é essa a motivação de Adálio. Adálio tem um tema para sua música, um tema de amor. Quer contar a sua história, mas não toda, que nem mesmo a palavra contada abarcaria, quer contar a sua história de amor. É essa a narrativa da música: sua perda amorosa. Seu repente é na verdade uma cantiga de amor. É desse amor que ele quer lembrar e por isso faz a música. São intenções distintas e por isso, não cabem na palavra cantada esses outros temas que dizem respeito a uma outra vida. A música é um divisor de águas. Com a música ele garante uma reserva de memória de sua vida no nordeste, e essa vida só passa a existir nesse plano, no plano da lembrança. A partir daí Adálio se entrega à sua nova realidade e não pensa mais em voltar para sua terra natal.

A palavra cantada diz respeito à sua memória pessoal/individual e a palavra contada a uma memória mais grupal/coletiva. Nas duas formas de contar, uma série de temas apresentados por Adálio revelam duas memórias de um tipo de experiência, que juntas, constroem uma possível identidade para ele. Não mais aquela identidade congelada, oficial, mas uma identidade movente, múltipla. A operação que se processa em história oral é a seguinte: no momento da entrevista ( a contingência e o ouvinte) o colaborador constrói uma memória a partir da sua narrativa, que se pauta na sua experiência de vida e que ao ser trabalhada em colaboração gera uma ou várias identidades possíveis.

O primeiro componente dessa "identidade Adálio" é a experiência do deslocamento. Ele inicia a sua palavra contada como um migrante: "eu saí pra cá". O componente de identidade migrante se cola a uma outra, a da experiência do nacionalismo e do patriotismo, que é o motivo gerador do seu deslocamento. Contudo, o componente essencial da “identidade Adálio" é a perda. 
Tanto na palavra cantada quanto na contada ele perdeu tudo. O sentimento de perda se liga ao anúncio de uma última purificação, de uma peregrinação, de uma viagem. As perdas de Adálio se iniciam com uma viagem. Com ela, ele perde a família e toda uma vida no nordeste. Na Amazônia ele se transforma em empregado, não no sentido como conhecemos atualmente, do trabalhador assalariado. Esse emprego diz mais sobre uma relação quase de escravidão e ausência de direitos legais. Ao se transformar em empregado, ele deixa de ser o filho do dono da bodega, e dono de algumas terrinhas e animais. Situação que, aliás, ele persegue, ele quer se tornar dono de umas terrinhas e consegue, mas aí mais uma vez isso lhe é tirado. E lhe é tirado por uma outra perda, a da saúde. Ele fica doente. Com a doença ele perde a perna e com a perna a possibilidade de gerir e tomar conta das suas terras. No meio de tantas perdas, ele, novamente, perde sua família: mulher e filho morrem. Ele está só. Ele era casado, agora é viúvo. Ele busca a solidão, ele ficou na comunidade até conseguir uma prótese, e ao conseguir se mudou para um quartinho nos fundos de uma mercearia no município de Candeias do Jamarí, em Rondônia. Adálio, também, perde a pureza e a limpeza. A doença o tornou sujo, manchado. Antes ele era limpo, ele era são. Hoje ele é doente. O que Adálio tem fica ao seu redor. Sentado numa rede, ele reúne tudo o que lhe restou: o violão nos braços; num canto as muletas; embaixo da rede uma malinha, um espelho, um vidro de leite de rosas, sapatos e sua prótese; atrás da rede, apoiados numa mesinha, o ventilador e o seu rádio. E por último, lhe restou a fala e o poder de contar sua história. Essa é a última imagem que tenho de Adálio ${ }^{25}$.

Tinha como intuito inicial contribuir com a discussão de uma história oral que vem aos poucos reivindicando certa autonomia em relação às outras disciplinas. Mas sei que o que fiz foi, apenas, assanhar os debates e promover mais dúvidas. O que apresentei foi mais uma forma de se fazer história oral. Radicalizei ao escolher um único colaborador, a fim de explorar as possibilidades desse conhecimento. Agora não sei mais se fiz um uso ou se cometi um abuso. Achei que numa conclusão de tese teria mais respostas que perguntas, mas não é esse o caso. Ainda há muito trabalho a fazer, muitos caminhos a percorrer. A história da história oral no Brasil está para ser pensada e uma forma mais eficiente de análise das narrativas que constituímos em história oral, ainda precisa ser estabelecida, se o caminho for a autonomia da história oral.

\footnotetext{
${ }^{25}$ Ver Foto 17
} 


\section{BIBLIOGRAFIA}

\section{HISTÓRIA ORAL/ ORALIDADE/ MEMÓRIA}

ALBERTI, Verena. História Oral: A Experiência do CPDOC. Rio de Janeiro, CPDOC/FGV, 1989.

Manual de História Oral. Rio de Janeiro, FGV, 2004.

Ouvir Contar: Textos em História Oral. Rio de Janeiro, FGV, 2004.

ARAÚJO, Paulo César de. Eu Não Sou Cachorro Não: Música Popular Cafona e Ditadura militar. Rio de Janeiro, Record, 2002.

ATAIDE, Yara Dulce Bandeira de. Decifra-me ou Devoro-te: História Oral de Vida dos Meninos de Rua de Salvador. São Paulo, Loyola, 1993.

2002.

BARNET, M. Memórias de um Cimarron. Marco Zero, São Paulo, 1986.

BENJAMIN, Walter. O Narrador. MAGIA E TÉCNICA, ARTE E POLÍTICA: 197-221, Obras Escolhidas, Vol. 1. São Paulo, Brasiliense, 1987.

BOSI, Ecléa. Memória e Sociedade: Lembranças de Velhos. São Paulo, Companhia das Letras, 1995.

O Tempo Vivo da Memória: Ensaios de Psicologia Social. São Paulo, Atelier Editorial, 2003.

BOURDIEU, Pierre. A Miséria do Mundo. Petrópolis, Vozes, 1997.

BRANDÃO, Carlos Rodrigues (org). As Faces da Memória. Campinas, col. Seminários 2, Editora da Unicamp, s/d.

BRETON, Binka Le. Todos Sabiam: A Morte Anunciada do Padre Josimo. São Paulo. Edições Loyola, 2000.

BURGOS, Elizabeth. Me Llamo Rigoberta Menchú y Así Me Nació la Conciencia. México, Siglo Veintiuno, 1987.

BRUGAT, Dolores Pla. Los niños de Morelia. México, Instituto Nacional de Antropología e Historia, 1985.

BRUNER, Jerome; WEISSER, Susan. A Invenção do Ser: A Autobiografia e Suas Formas. OLSON, David R.; TORRANCE, Nancy. CULTURA ESCRITA E ORALIDADE: 141-161, São Paulo, Ática, 1995.

CALDAS, Alberto Lins. Seis Ensaios de História Oral. Caderno de Criação, Porto Velho, Centro de Hermenêutica do Presente, no 15, ano V, Junho, 1998, Pág. 38/60.

Transcriação em História Oral in NEHO-HISTÓRIA, Revista do Núcleo de Estudos em História Oral. São Paulo, n¹, USP/FFLCH/DH, Novembro, 1999, pp.71-79.

Oralidade, Texto e História: Para Ler a História Oral. São Paulo, Loyola, 1999a.

Nas Águas do Texto: Palavra, Experiência e Leitura em História Oral. Porto Velho, Edufro, 2001.

CALDAS, Fabíola Lins. A Cidade dos Excluídos: um Projeto em História Oral. Caderno de Criação: 14/22, Porto Velho, Centro de Hermenêutica do Presente, no 20, ano VI, outubro, 1999.

. Cápsula Narrativa: História e Usos de um Conceito. Caderno de Criação: 05/10, Porto Velho, Centro de Hermenêutica do Presente, $n^{\circ}$ 26, ano VIII, outubro, 2001.

; CALDAS, Alberto Lins. Nordestinos na Amazônia: História Oral com Soldados da Borracha: A Experiência de Dois Mundos. Projeto de Pesquisa, Porto Velho, Universidade Federal de Rondônia, 2002/2004.

CORREIA, C. H. P. História Oral: Teoria e Técnica. Florianópolis, Universidade Federal de Santa Catarina, 1978.

FERREIRA (1), Jerusa Pires. Os desafios da Voz Viva in: Os Desafios Contemporâneos da História Oral. Campinas, CMU/UNICAMP, 1997. Pág. 59 a 68.

.Oralidade em Tempo e Espaço. São Paulo, EDUC/FAPESP, 1999.

. As Armadilhas da Memória: E Outros Ensaio. São Paulo, Atelier Editorial, 2003.

FERREIRA(2), Marieta de Moraes. (org.) Entre-vistas: Abordagens e Usos da História Oral. Rio de Janeiro, Editora da Fundação Getúlio Vargas, 1994.

(2). (org.). História Oral e Multidisciplinariedade. Rio de Janeiro, Diadorin Editora, 1994.

(2); AMADO, Janaína (et al.). Usos e Abusos da História Oral. Rio de Janeiro, Fundação Getúlio Vargas, 1996. 
(2); Fernandes Tânia Maria e Alberti, Verena (orgs.). História Oral: Desafios para o Século XXI. Rio de Janeiro, Casa Oswalo Cruz, 2000.

FRANÇOIS, Frederic. Práticas do Oral. Carapicuiba, Pró Forno Departamento editorial, 1996.

FREITAS, Sônia Maria de. História Oral: Possibilidades e Procedimentos. São Paulo, Humanitas, 2002.

GARRET, Annette. A Entrevista, Seus Princípios e Métodos. Rio de Janeiro, Agir, 1967.

GATTAZ, André Castanheira. Braços da Resistência: Uma História Oral da Migração Espanhola. São Paulo, Xamã, 1996.

Pensando Meio Século de História Oral. Caderno de Criação, Porto Velho, Centro de Hermenêutica do Presente, no 15, ano V, Junho, 1998, Pág. 28/37.

GRELE, Ronald J. Envelopes of Sound: The Art of Oral History. New York, Pleager Plublishers, 1991.

GUSDORF, Georges. Lignes de Vie 1: Les Écritures du Moi. Paris, Éditions Odile Jacob, 1991. Auto-Bio-Graphie. Paris, Éditions Odile Jacob, 1991.

HALBWACHS, Maurice. A Memória Coletiva. São Paulo, Vértice, 1990.

HAVELOCH, Eric. A Equação Oralidade-Cultura Escrita: Uma Fórmula Para A Mente Moderna. OLSON, David R.; TORRANCE, Nancy: Cultura Escrita e Oralidade: 17-34, São Paulo, Ática, 1995. Prefácio a Platão. Campinas, Papirus, 1996a.

A Revolução da Escrita na Grécia. UNESP/Paz e Terra, Rio de Janeiro, 1996b.

JOUTARD, Philippe. Esas Voces que nos Llegan del Pasado. México, Fondo de Cultura Económica, 1986.

KAKAR, Sanjiv. Leprosy in Índia: The Intervention of Oral History. In Oral History, the Journal of the oral history society, volume 23, number 1, Spring, 1995, Págs. 37/45.

KOTRE, John. Luvas Brancas: Como Criamos a Nós Mesmos Através da Memória. São Paulo, Mandarim, 1997.

LANG, Alice Beatriz da S. Gordo. História Oral: muitas dúvidas, poucas certezas e uma proposta. (Re)Introduzindo História Oral no Brasil. São Paulo, Xamã, 1996, Págs. 33/47.

LEWIS, Oscar. Antropologia de la Pobleza: Cinco Familias. México, Fondo de Cultura Económica, 1969. LIENHARD, Martin. La Voz y su Huella. México, Casa Juan Pablos, 2003.

MACIEL, Márcia Nunes. A Construção de Uma Identidade: História Oral com os Cassupá. Monografia, Departamento de História, Porto Velho, Universidade Federal de Rondônia, 2002.

MARCUSCHI, Luiz Antônio. Análise da Conversação. São Paulo, Ática, 1991.

MEDINA, Cremilda de Araújo. Entrevista: o Diálogo Possível. São Paulo, Ática, 1990.

MEIHY, José Carlos Sebe Bom. A Colônia Brasilianista: História Oral de Vida Acadêmica. São Paulo, Nova Stella, 1990.

Canto de Morte Kaiowá: História Oral de Vida. São Paulo, Loyola, 1991.

História e Memória ou Simplesmente História Oral? Anais do Encontro de História e Documentação Oral: 5-11, Brasília, UnB, 1993.

Manual de História Oral. São Paulo, Loyola, 1996 a/2004a /2005.

org.). (Re)Introduzindo História Oral no Brasil. São Paulo, Xamã, 1996b.

; Pensando as Narrativas de Certas Mulheres. in SANTOS, Andrea Paula dos. PONTO DE VIDA: CIDADANIA DE MULHERES FAVELADAS. São Paulo, Loyola, 1996c.

Tres Alternativas Metodológicas: Historia de Vida, Historia Temática y Tradición Oral.

HISTORIA Y TESTIMONIOS ORALES, México, Instituto Nacional de Antropologia e Historia: $57-$ 72, 1996d.

Brasil Fora de Si: experiências de brasileiros em Nova York. São Paulo, Parábola, 2004b.

The Radicalization of Oral History in: Words \& Silences: Journal of the Internacional oral history association. México, vol. 2, N 1, IOHA, Junho, 2003, pp 31-41.

Augusto \& Lea: um caso de (des)amor em tempos modernos. São Paulo, Contexto, 2006.

MONTENEGRO, Antônio Torres. História Oral e memória: a cultura popular revisitada. São Paulo, Contexto, 1992.

ONG, Walter. Oralidade e Cultura Escrita. Campinas, Papirus, 1998.

OLSON, David; TORRANCE, Nancy. Cultura Escrita e Oralidade. São Paulo, Ática, 1995.

ORLANDI, Eni Puccinelli. Sobre Interpretação. Campinas, Unicamp, 1996.

As Formas do Silêncio: no movimento dos sentidos. Campinas, Unicamp, 1997.

PASSERINI, Luisa. Mitobiografia em História Oral. Revista Projeto História: 29/40, No 10, São Paulo, 1993.

PATAI, Dafne; GLUCK, S. B. Women's Words. The Feminist Practice of Oral History. New York/London, Routledge, 1991. 
PÊCHEUX, Michel. O Discurso. Campinas, Pontes, 1990.

POLLAK, Michael. Memória, Esquecimento, Silêncio. Rio de Janeiro, v.2, n.3, Estudos Históricos, 1989, pp.3-15.

PORTELLI, Alessandro. "Sonhos ucrônicos: memórias e possiveis mundos dos trabalhadores", in Projeto de História. PUC, São Paulo, n.10, dez. 1993, pp. 41-58.

"O que faz a História Oral diferente". in Projeto de História. Revista do Programa de Estudos Pós-Graduados em História e do departamento de história da PUC, n.14, São Paulo, EDUC, fev. 1997, pp. 31-32.

"História Oral como Gênero" in: Projeto de História: História e Oralidade. Revista do Programa de Estudos Pós-Graduados em História e do departamento de história da PUC. $\mathrm{n}^{\circ}$ 22. São Paulo, EDUC, Jun. 2001. pp. 09/36.

QUEIROZ, Maria Isaura Pereira. Variações Sobre a Técnica de Gravador no Registro da Informação Viva. São Paulo, CERU/FFLCH/USP, Coleção Textos, 1985.

RODRIGUES, Dirce Spedo; VIANNA, Cláudia Pereira (coords.). Eu, Ex-Menor Abandonado. São Paulo, Loyola, 1989.

SANTOS, Andrea Paula dos. Ponto de Vida: Cidadania de Mulheres Faveladas. São Paulo, Loyola, 1996.

SILVA, Emmanoel Gomes. Espíritos Acuados: História Oral com Apenados. Monografia, Departamento de História, Porto Velho, Universidade Federal de Rondônia, 1999.

SOUZA, Edinéia Bento de. O Mito do Herói: História Oral de Vida com Homens da Comunidade Santa Marcelina. Monografia, Departamento de História, Porto Velho, Universidade Federal de Rondônia, 2002.

SOUZA, Maria Cristiane Pereira. Vozes que Curam: História Oral de Vida. Monografia, Departamento de História, Porto Velho, Universidade Federal de Rondônia, 2001.

SCHAMA, Simon. Paisagem e Memória. São Paulo, Companhia das Letras, 1996.

SCHWARZTEIN, D. (org.). La historia oral. Buenos Aires, Centro Editorial de America Latina, 1991.

SIMSON, Olga Rodrigues de Moraes (org.). Os Desafios Contemporâneos da História Oral. Campinas, CMU/UNICAMP, 1997.

THOMPSON, Paul. A Voz do Passado: História Oral. Rio de Janeiro, Paz e Terra, 1992.

TRABATTONI, Franco. Oralidade e Escrita em Platão. São Paulo/Ilhéus, Discurso Editoral/ Editus, 2003.

VIEZZER, Moema. “Se Me Deixam Falar ...”: Domitila: Depoimento de uma Mineira Boliviana. São Paulo, Global, 1984.

Se Alguém Quiser Saber... . São Paulo, Global, 1982.

VILANOVA, Mercedes. Las Mayorias Invisibles: Explotación Fabril, Revolución y Represión. Barcelona, Icaria/Antrazyt, 1997.

VILAS BOAS, Sérgio. Perfis: e como Escrevê-los. São Paulo, Summus, 2003.

Biografia e Biógrafos: Jornalismo sobre Personagens. São Paulo, Summus, 2002.

WOLDENBERG, José. Las Ausencias Presentes. México, Cal y Arena, 1992.

ZUMHTOR, Paul. A Letra e a Voz. São Paulo, Companhia das Letras, 1993.

Introdução à Poesia Oral. São Paulo, Hucitec, 1997.

Performance, Recepção e Leitura. São Paulo, EDUC, 2000.

\section{AMAZÔNIA/RONDÔNIA}

AMARAL, José Januário de Oliveira. Terra Virgem, Terra Prostituta: O Processo de Colonização de Rondônia. São Paulo, Dissert., FFLCH/USP, 1994.

BECKER, Bertha K. Amazônia. São Paulo, Ática, 1990.

BENCHIMOL, Samuel. Os "Cearenses" - Nordestinos na Amazônia. In: Amazônia - formação social e cultural. Manaus, Valer, 1999.

Amazônia: Um Pouco Antes e Além Depois. Manaus, Umberto Calderano, 1977.

O Cearense na Amazônia. Rio de Janeiro, Seção de Documentação e Relações Públicas, 1965.

BEZERRA, Ararê M. Amazônia - lendas e mitos. 2 ed. rev. aum. Belém, TELEPARA/CECAFAM (Centro Cultural de Arte e Folclore da Amazônia), 1985.

BITTENCOUT, Artur. O Homem Amazonense e o Espaço. Rio de Janeiro, Arti-Nova, 1969. 
CUNHA, Silvio Percivo. O Xadrez da Terra: Um Estudo da Colonização Dirigida em Rondônia. Dissert., Belém, UFPA, 1985.

DAOU, Ana Maria. A Belle Époque Amazônica. São Paulo, Jorge Zahar Editor, 2000.

DEAN, Warren. A Luta Pela Borracha no Brasil. São Paulo, Nobel, 1989.

FERREIRA, Manoel Rodrigues. Nas Selvas Amazônicas. São Paulo, Gráfica Biblos, 1961.

A Ferrovia do Diabo. São Paulo, Melhoramentos, 1987.

GONDIM, Neide. A Invenção da Amazônia. São Paulo, Marco Zero, 1994.

GONSALVES Marco Antônio. Entrevista com Osmarino Amâncio Rodrigues. São Paulo, ISA, 1998. mímeo.

GOULART, José Alípio. O Regatão. Rio de Janeiro, Conquista, 1968.

HUGO, Vitor. Cinquenta Anos do Território Federal do Guaporé: 1943-1993. Brasília, Ser, 1995.

JUNIOR, Peregrino. Histórias da Amazônia. Rio de Janeiro, José Olympio, 1936.

KRENAK, Ailton; AMÂNCIO Osmarino. Aliança dos Povos da Floresta. São Paulo, CEDI, 1989.

LEONEL, Mauro. A Morte Social dos Rios. São Paulo, Perspectiva, 1998.

LOUREIRO, João de Jesus Paes. Cultura Amazônica: Uma Poética do Imaginário. Belém, Cejup, 1995.

MARTINELLI, Pedro. A Batalha da Borracha na II Guerra Mundial e Suas Conseqüências Para o Vale Amazônico. Tese, São Paulo, FFLCH/USP, 1985. mimeo

Amazônia: O Povo das Águas. São Paulo, Terra Virgem, 2000.

NECES, Marcus Vinicius. "A heróica e desprezada batalha da borracha”. In: Revista História Viva. São Paulo, Editora Abril, No 8 - junho de 2004.

NEVES, Frederico de Castro. Getúlio e a seca: políticas emergenciais na era Vargas. Rev. bras. Hist., 2001, vol.21, no.40, p.107-129. ISSN 0102-0188.

NUNES, Jersey de Brito. Memórias de um Seringueiro. Acre, 1996.

O’DWYER, Eliane Cantarino. Seringueiros na Amazônia: Dramas Sociais e o Olhar Antropológico. Rio de Janeiro, EDUFF, 1998.

OLIVEIRA, Raimundo Alves. O Soldado da Borracha. Rio Branco, Acre, s/d.

PINTO, Emanuel Pontes. Rondônia, Evolução Histórica. Rio de Janeiro, Expressão e Cultura, 1993.

PINTO, Roquette. Rondônia. Col. Brasiliana, vol. 39, 4ª ed.,São Paulo, Companhia Editora Nacional, 1938.

RAMOS. Borracha: Seringueiros e Seringalistas - Verdade e Lenda. São Paulo, IPT, s/d.

SANTOS, Maria Luzia; SILVA, Maria das Graças Nascimento. A Mulher nos Seringais da Amazônia. Porto Velho, CNPq/UNIR, 1996. mimeo.

SILVA, Amizael Gomes da. No Rastro dos Pioneiros. Porto Velho, SEDUC, 1984. Amazônia: Porto Velho. Porto Velho, Palmares, 1991.

SOUZA, Marcio. O Empate Contra Chico Mendes. São Paulo, Marco Zero, 1990.

Breve História da Amazônia. São Paulo, Marco Zero, 1994.

TEIXEIRA, Carlos Correia. O Aviamento e o Barracão na Sociedade do Seringal. Dissert., FFLCH/USP, São Paulo, 1980.

WEINSTEIN, Barbara. A Borracha na Amazônia: Expansão e Decadência (1850-1920). São Paulo, Hucitec-Edusp, 1993.

\section{GERAL}

ANDERSON, Benedict. Imagined Communities: Reflections on the Origin and Spread of Nationalism. Londres, Verso, 1983.

ASSARÉ, Patativa. Patativa do Assaré uma Voz do Nordeste. São Paulo, Hedra, 2000.

ASSIS, Machado de. Memórias Póstumas de Brás Cubas. Porto Alegre, L\&PM, 1997.

BACHELARD, Gaston. A Água e os Sonhos. São Paulo, Martins Fontes, 1989.

BAKHTIN, Mikail M.. Marxismo e Filosofia da Linguagem: Problemas Fundamentais do Método Sociológico nas Ciências da Linguagem. São Paulo, Hucitec, 1986.

BARTHES, Roland. O Prazer do Texto. São Paulo, Perspectiva, 1977a.

Roland Barthes por Roland Barthes. São Paulo, Cultrix, 1977b.

Fragmentos de um Discurso Amoroso. São Paulo, Francisco Alves, 1981.

A Câmara Clara. Rio de Janeiro, Nova Fronteira, 1984.

Michelet. São Paulo, Companhia das Letras, 1991.

Inéditos 1: Teoria. Coleção Roland Barthes, Vol.1, São Paulo, Martins Fontes, 2004. 
BAUDELAIRE, Charles. As Flores do Mal. Rio de Janeiro, Nova Fronteira, 1985.

BAUDRILLARD, Jean. Da Sedução. Campinas, Papirus, 1991.

BENJAMIN, Walter. Obras Escolhidas. São Paulo, 3 Vol, Brasiliense, 1985/1987/1989.

Sobre o Conceito de História. São Paulo, Obras Escolhidas/222-234, vol 1. Brasiliense, 1985/1987/1988.

BHABHA, Homi. O Local da Cultura. Belo Horizonte, Editora da UFMG, 2001.

BOURDIEU, Pierre. O Poder Simbólico. Rio de Janeiro, Difel/Bertrand Brasil, 1989.

BRETON, Philippe. A Manipulação da Palavra. São Paulo, Loyola, 1999.

CAMPBELL, Joseph. O Herói de Mil Faces. São Paulo, Cultrix/Pensamento, sd. O Poder do Mito. São Paulo, Phalas Athenas, 1999.

CAMPOS, Haroldo de. A Operação do Texto. Col. Debates 134, São Paulo, Perspectiva, 1976. Metalinguagem. São Paulo, Cultrix, 1976.

; Paz, Octavio. Transblanco. Rio de Janeiro, Guanabara, 1986.

CASCUDO, Luís da Câmara. Geografia dos Mitos Brasileiros. São Paulo, Itatiaia, 1983.

Dicionário do Folclore Brasileiro. Rio de Janeiro, Instituto Nacional do Livro, 1954.

CASTRO, Josué de. Geografia da Fome. Rio de Janeiro, Cruzeiro, 1946.

CHATTERJEE, Partha. The Nation and its Fragments. Colonial and Postcolonial Histories. Princeton, Princeton University Press, 1993.

CHEVALIER, Jean; GUEERBRANT, Alain. Dicionário de Símbolos. $6^{a}$ ed., Rio de Janeiro, José Olympio, 1992.

CIRLOT, Juan-Eduardo. Dicionário de Símbolos. São Paulo, Moraes, 1984.

CLARO, Lenita B. Lorena. Hanseníase: Representações Sobre A Doença. FioCruz, Rio de janeiro, 1995.

CUNHA, Euclides da. Os Sertões. São Paulo, Ática, 1998.

DELEUZE, Gilles e GUATARI, Felix. Mil Platôs. 5 vols., São Paulo, Editora 34, 1995-1997.

DURAND, Gilbert. A Imaginação Simbólica. Cultrix/EDUSP, São Paulo, 1988.

ELIADE, Mircea. Imagens e Símbolos. São Paulo, Martins Fontes, 1991.

FEITOSA, Luiz Tadeu. Patativa do Assaré: A Trajetória de um Canto. São Paulo, Escrituras, 2003.

FOUCAULT, Michel. Eu, Pierre Rivière. Rio de Janeiro, Graal, 1984.

GEERTZ, Clifford. E1 Antropologo Como Autor. Barcelona, Paidos Studio, 1989.

GOMIDE, Leila Regina Scalia. Órfãos de pais vivos : a lepra e as instituições preventoriais no Brasil, estigmas, preconceitos e segregação. São Paulo, Dissertação (Mestrado)/FFLCH/USP, 1991.

GROS, Frédéric (org). Foucault: A Coragem da Verdade. São Paulo, Parábola, 2004.

HALL, Stuart. Da Diáspora: identidades e mediações culturais. Belo Horizonte, Editora da UFMG, 2003.

JUNG, Carl Gustav. O Homem e Seus Símbolos. Rio de Janeiro, Nova Fronteira, sd.

LACAN, Jacques. Seminário XI: Quatro Conceitos Fundamentais da Psicanálise. Rio de Janeiro, Jorge Zahar, 1979 .

LE GOFF, Jacques (apres.). As Doenças têm História. Lisboa, Terramar, 1997.

LONDRES, Maria José F.. Cordel: do Encantamento às Histórias de Luta. São Paulo, Duas Cidades, 1983.

MAINGUENEAU, Dominique. Novas Tendências em Análise do Discurso. Campinas, Pontes/UNICAMP, 1997.

MEIHY, José Carlos Sebe Bom. Carolina Maria de Jesus: Antologia Pessoal. Rio de Janeiro, Editora da UFRJ, 1996e.

; LEVINE, Robert M. Cinderela Negra: a saga de Carolina Maria de Jesus. Rio de Janeiro, Editora da UFRJ, 1994.

MATTOS, Débora Michels. "Fora do Arraial" : lepra e instituições asilares em Santa Catarina (19401950). São Paulo, Dissertação (mestrado)/FFLCH/USP, 2002.

MELO NETO, João Cabral de. Morte e Vida Severina. Rio de Janeiro, Nova Fronteira, 2000.

OLSON, David R.. O Mundo no Papel. São Paulo, Ática, 1997.

PRATT, Mary Louise. Olhos do Império. Relatos de Viagem e Transculturação. Bauru, EDUSC, 1999.

Pós-Colonialidade: Projeto Incompleto ou Irrelevante? Literatura e História: Perspectivas e

Convergências. Véscio, Luis Eugênio; Santos, Pedro Brum (orgs), 2000.

RAMOS, Graciliano. Vidas Secas. Rio de Janeiro, Record, 1982.

São Bernardo. Rio de Janeiro, Record, 1992. 
SILVA, Eduardo. Dom Oba II D'Africa, o Príncipe do Povo: Vida, Tempo e Pensamento de um Homem Livre de Cor. São Paulo, Companhia das Letras, 1997.

SOUZA, Liêdo M. de. Classificação Popular da Literatura de Cordel. Petrópolis, Vozes, 1976.

SPITZER, Carlos. Dicionário Analógico. Porto Alegre, Globo, 1952.

SPIVAK, Gayatri C. The Post-Colonial Critic. Interviews, Strategies, Dialogues. New York, Ed. Sarah Harasym, 1990.

SUASSUNA, Ariano. Auto da Compadecida. Rio de Janeiro, Agir, 1964.

SULERI. Sara. The Retoric of British India. Chicago, University of Chicago Press, 1992. 
GALERIA 


\section{Galeria de Fotografias}

Foto 1: Entrada Comunidade Santa Marcelina, Portão principal.

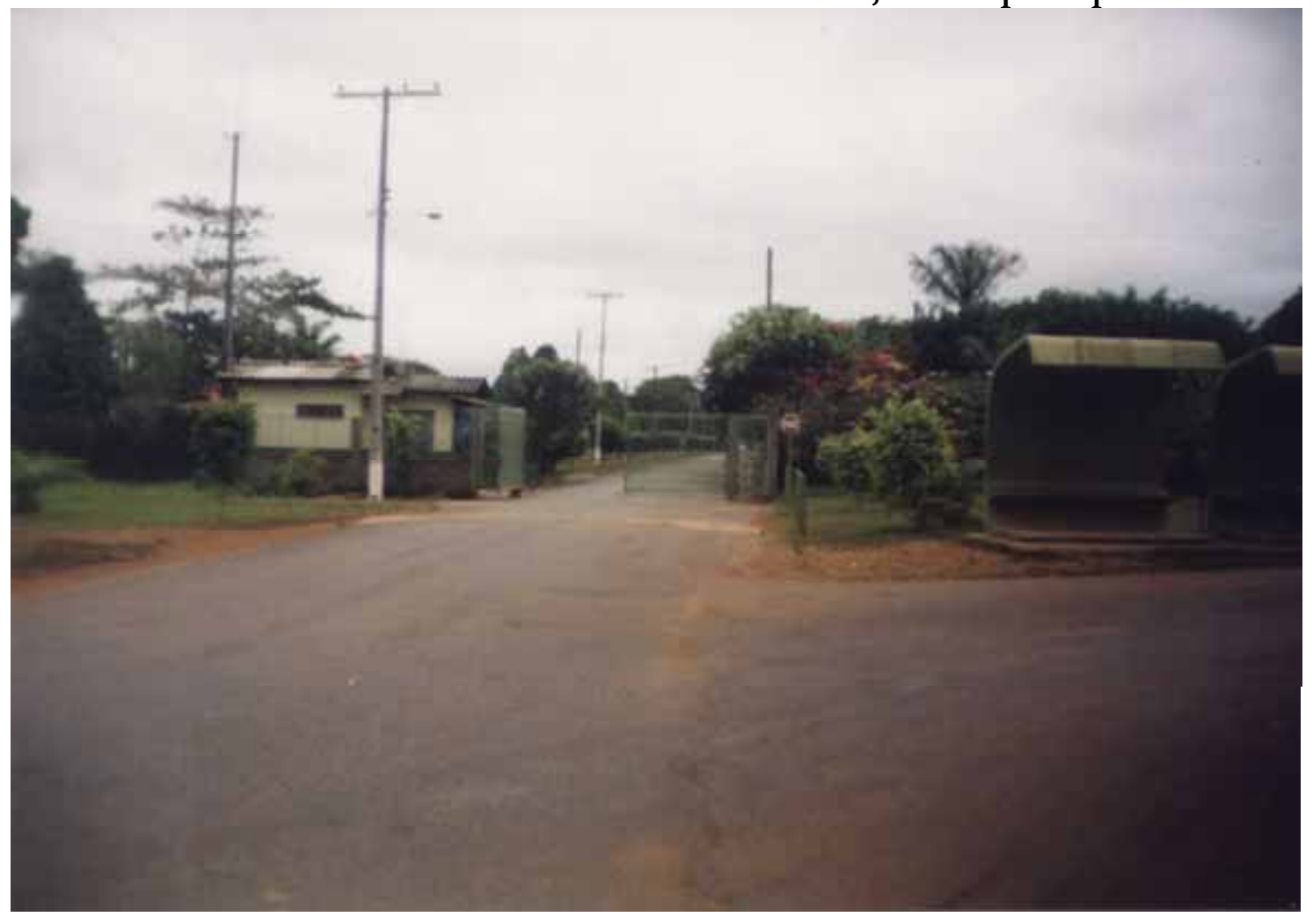

Foto 2: Entrada da Comunidade e quadra coberta da Escola Marcelo Cândia.

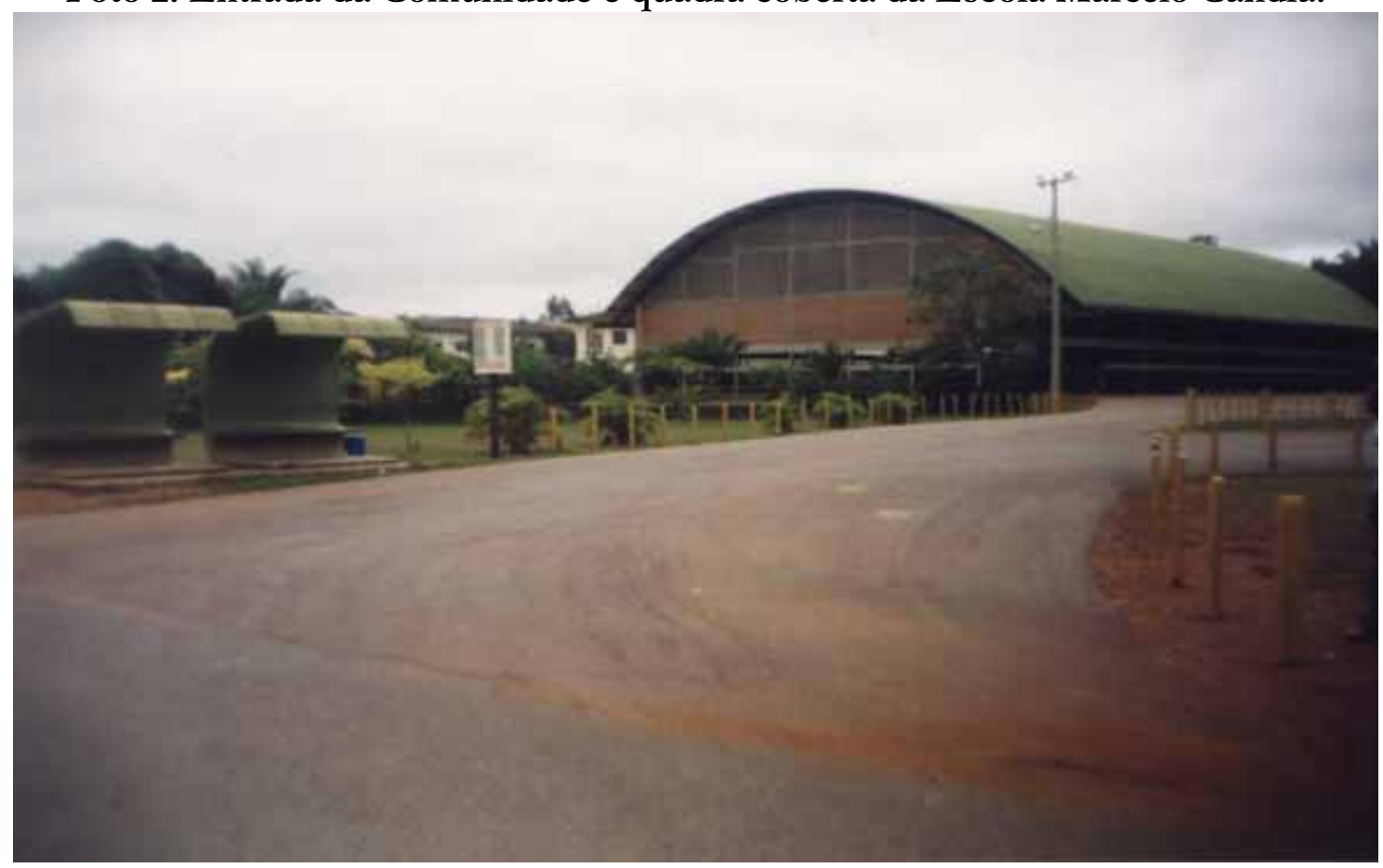


Foto 3: Rua de acesso local na Comunidade Santa Marcelina.

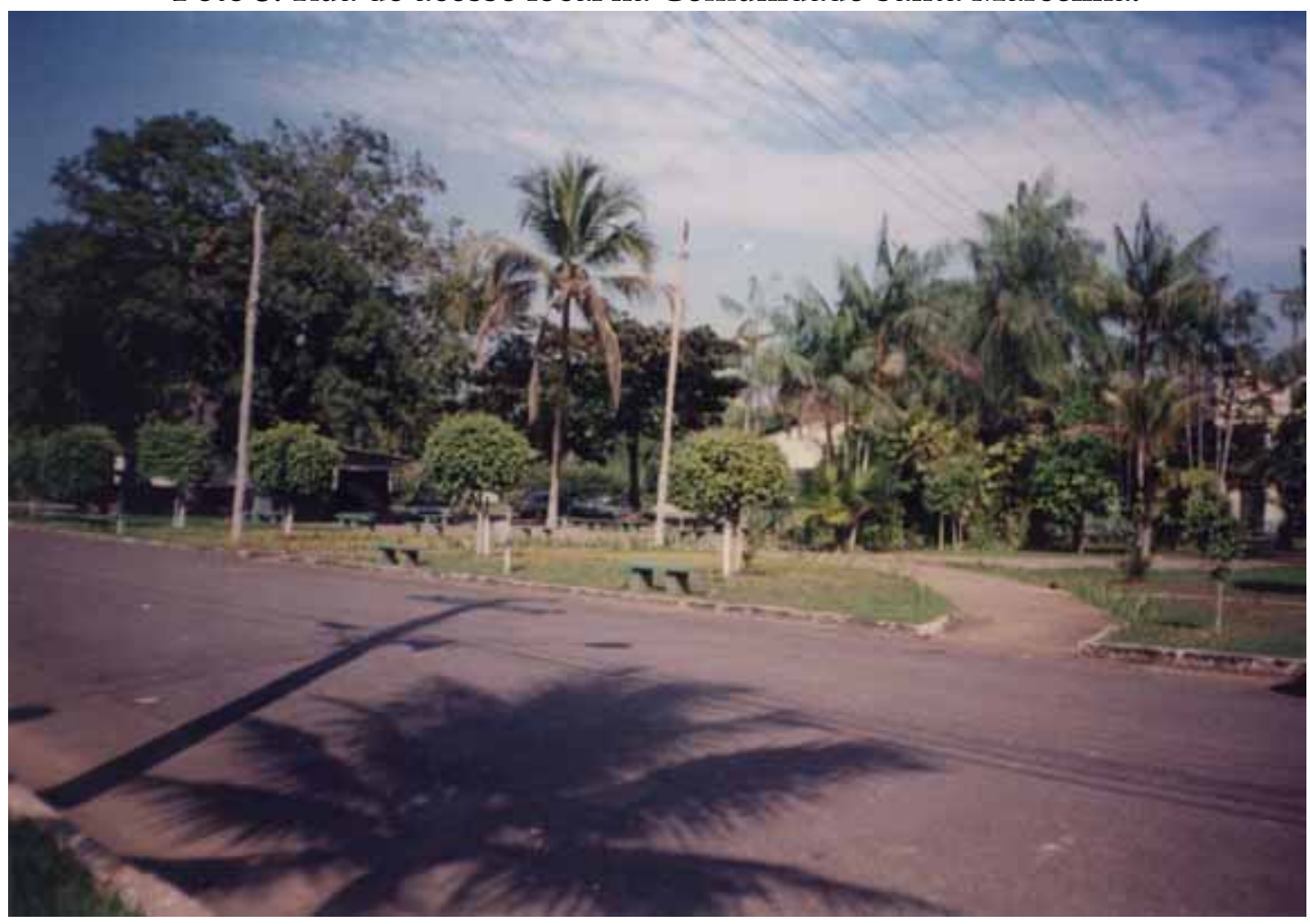

Foto 4: Escola Municipal Dr. Marcelo Cândia

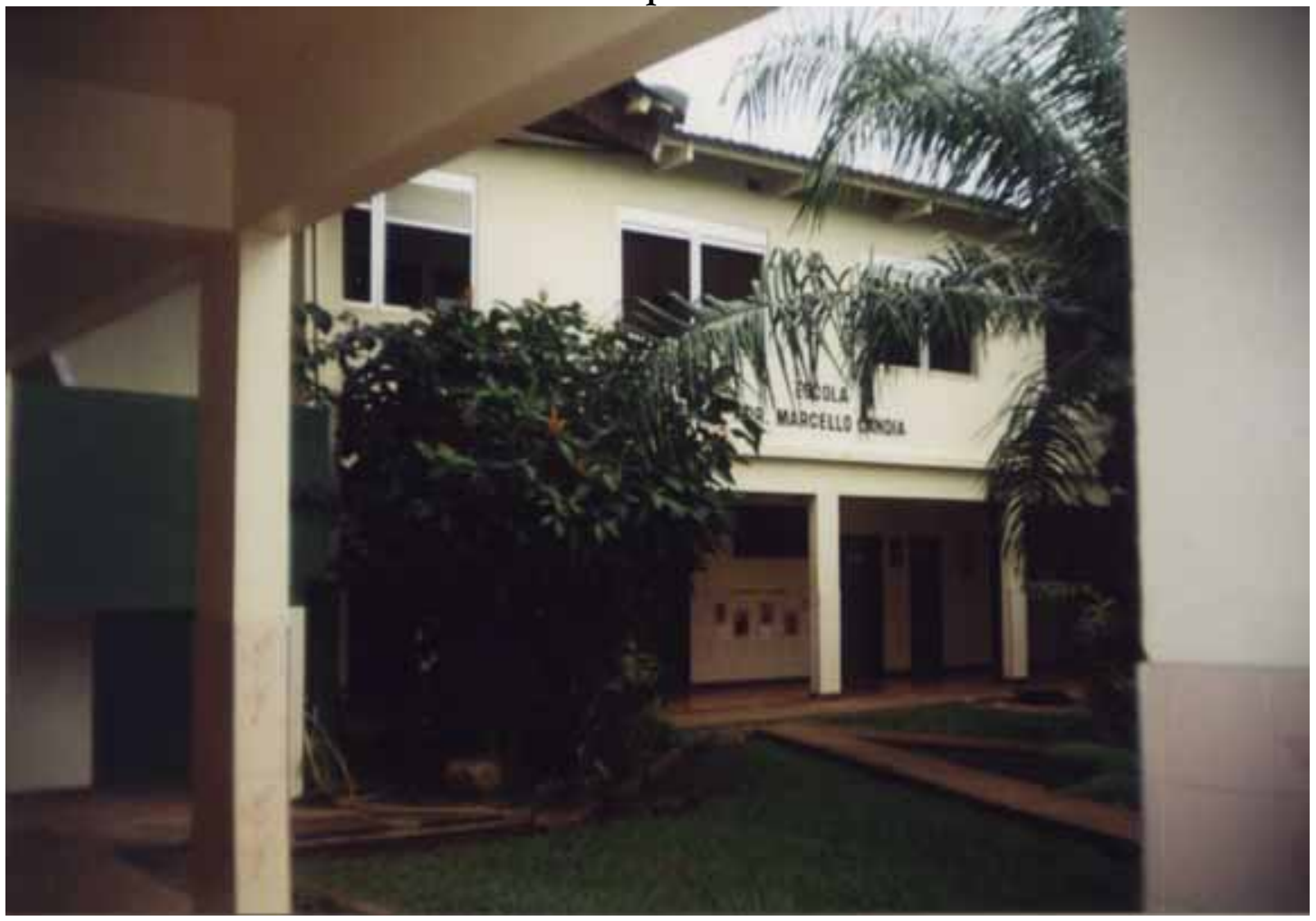


Foto 5: Hospital Dr. Marcelo Cândia

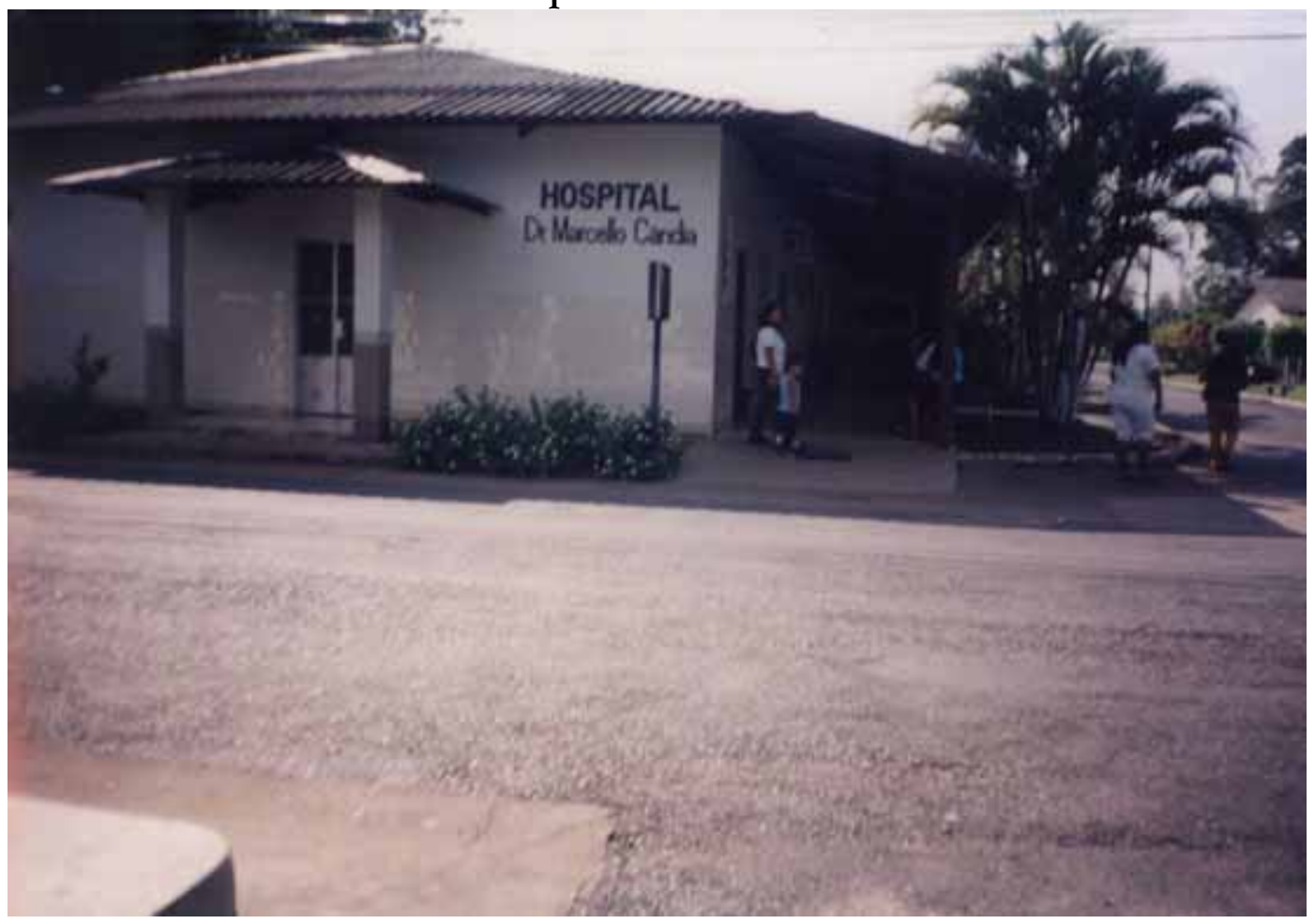

Foto 6: Capela

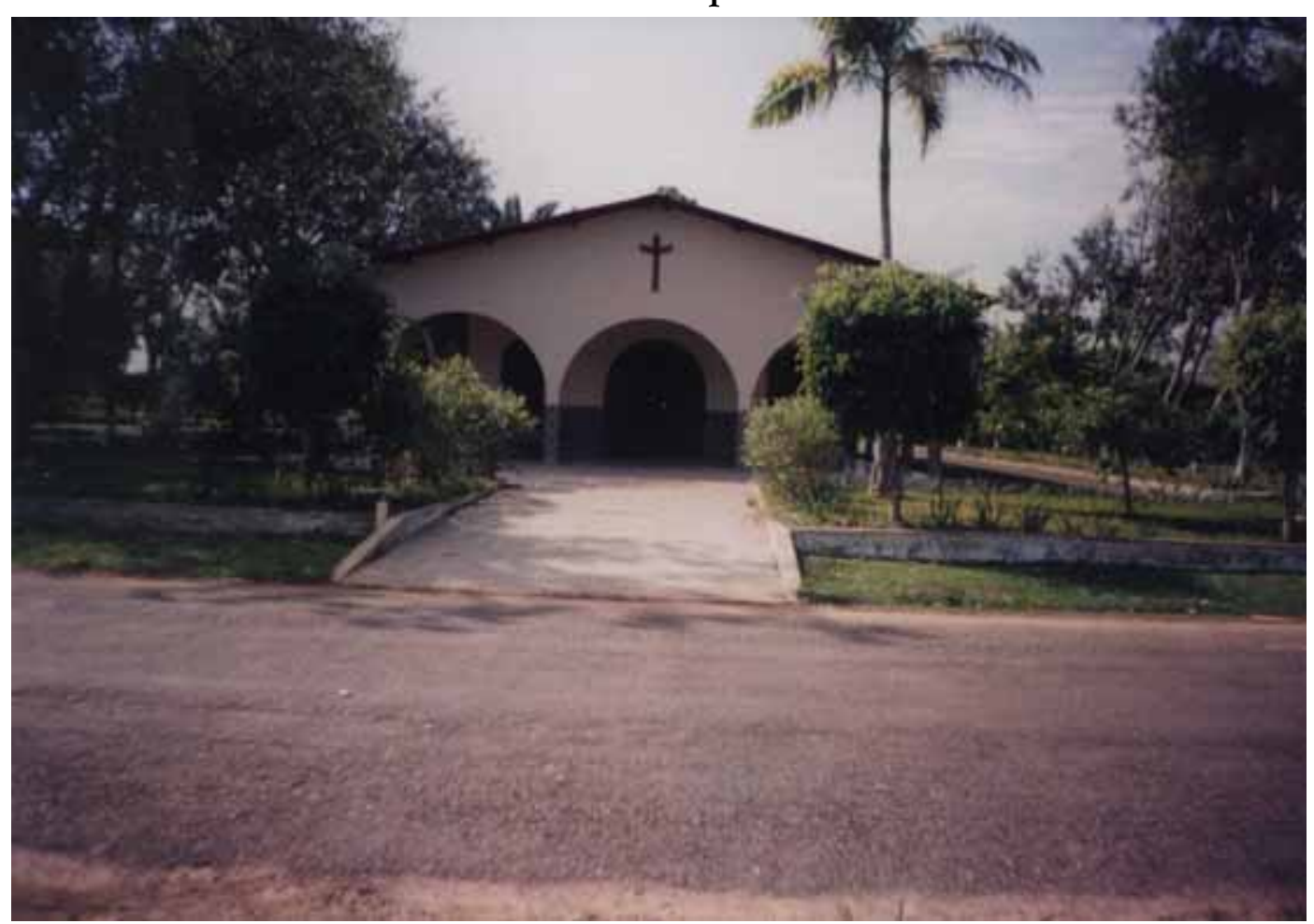


Foto 7: Oficina Ortopédica em um dos quatro pavilhões

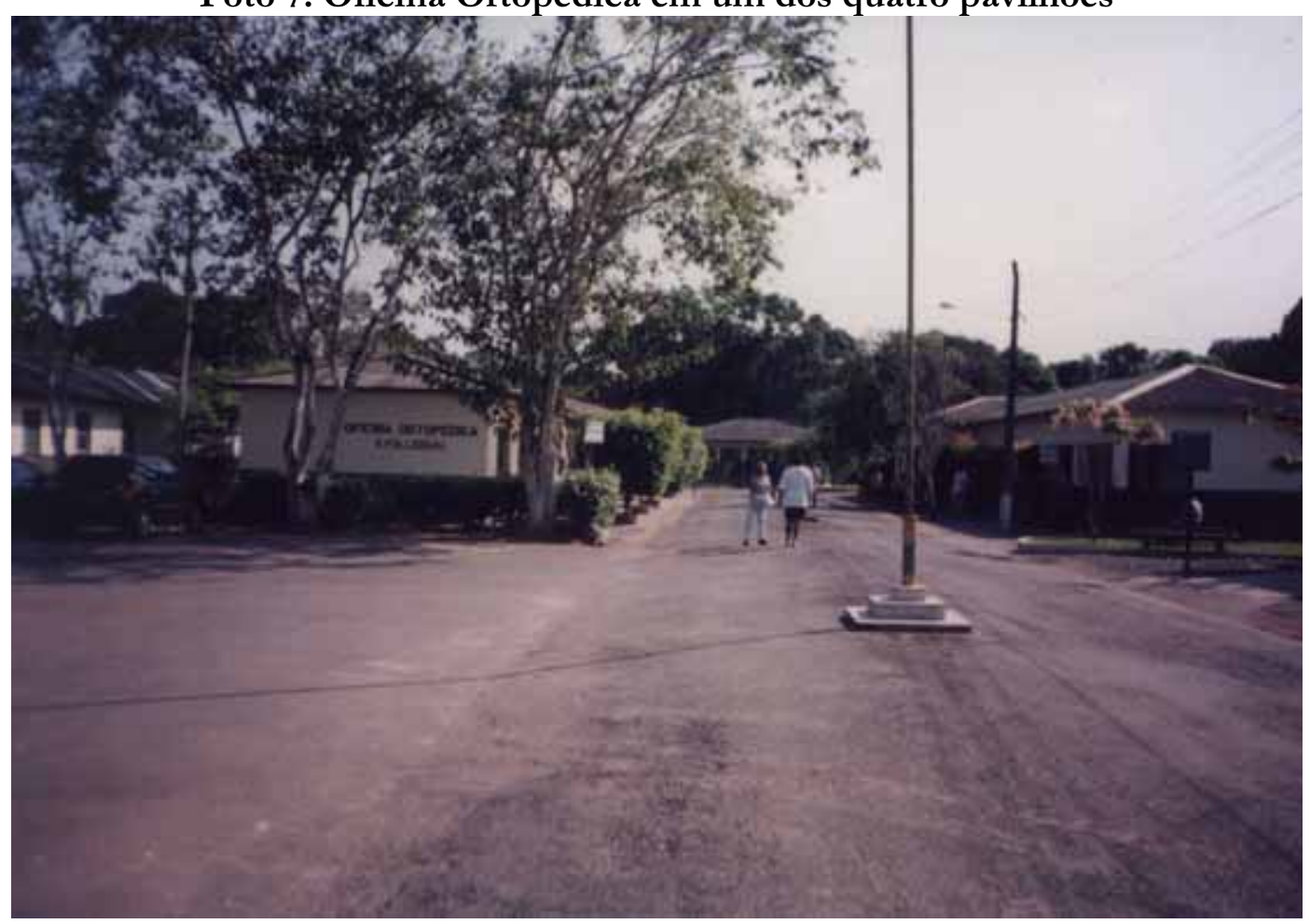

Foto 8: Casas da entrada da comunidade

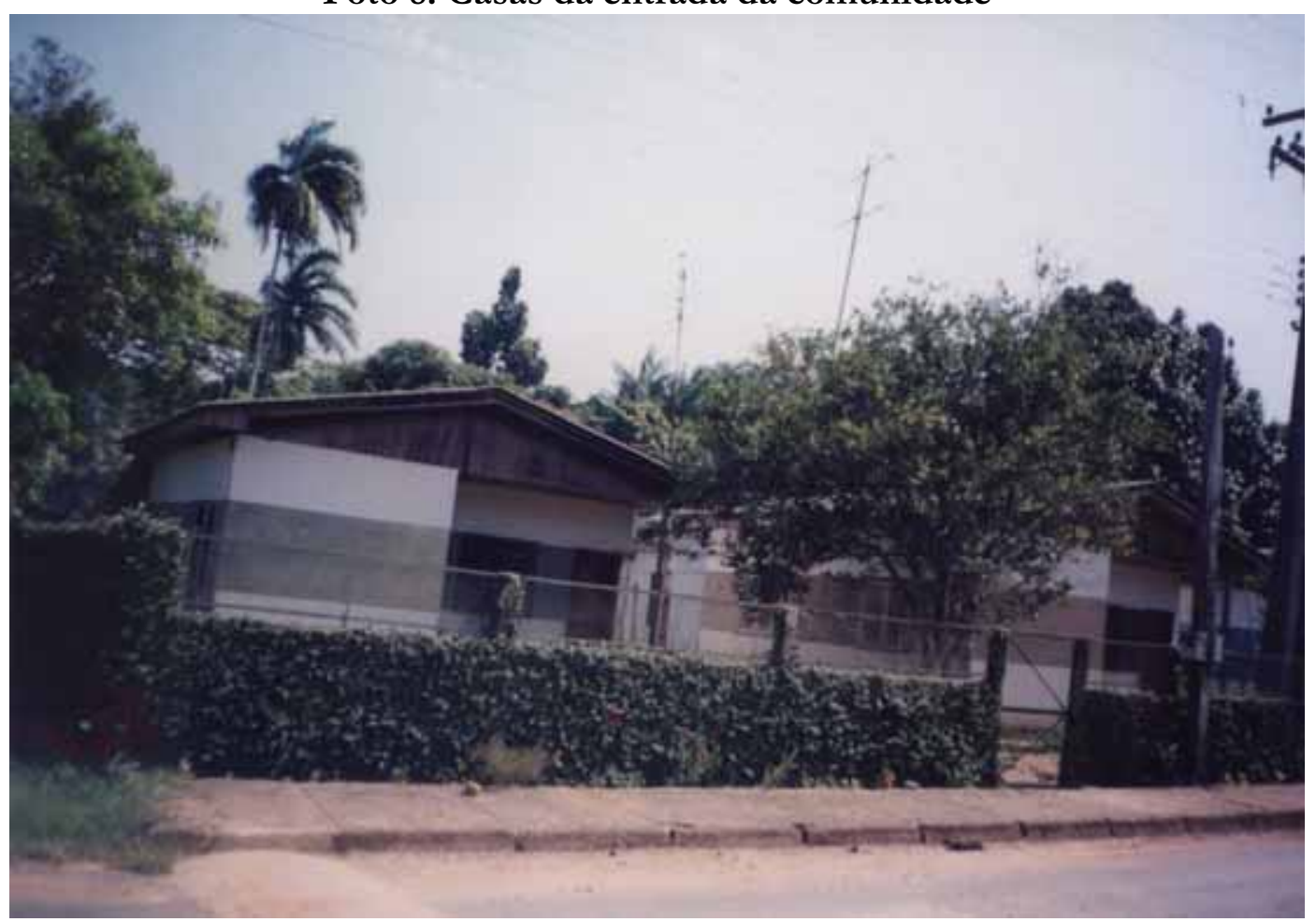


Foto 9: Moradia das Irmãs Marcelinas

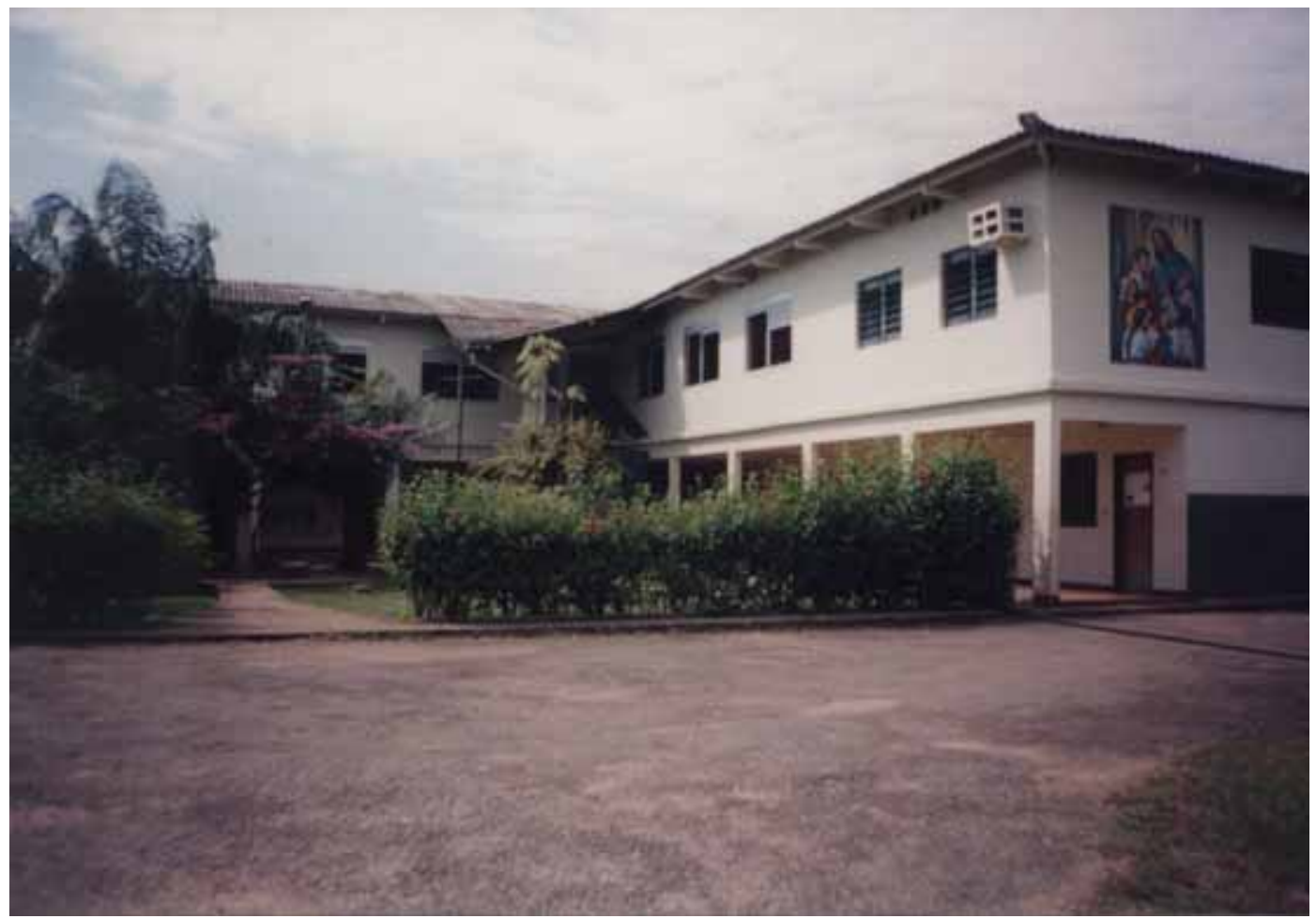

Foto 10: Pavilhão

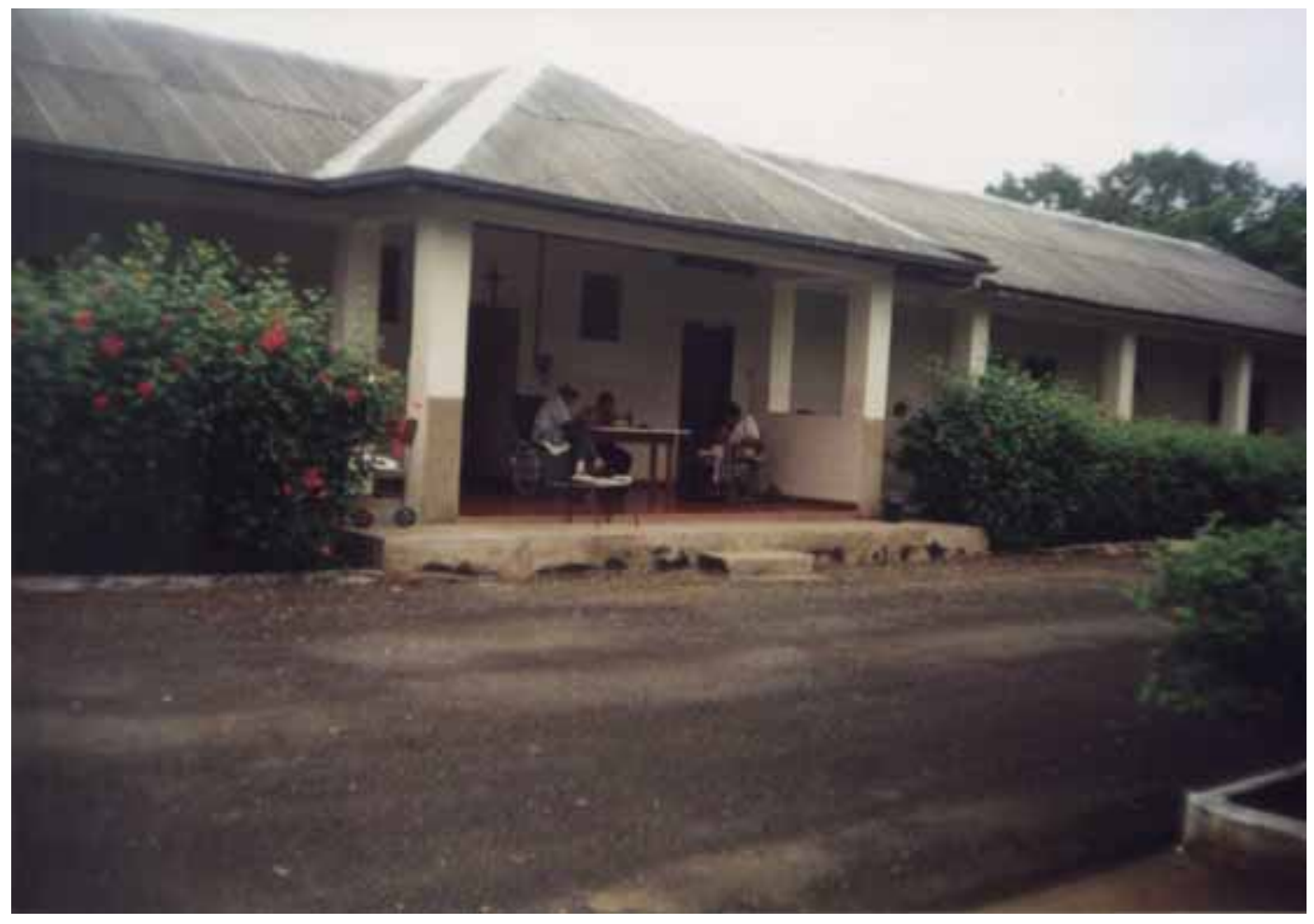


Foto 11: Entrada da área restrita: os Pavilhões

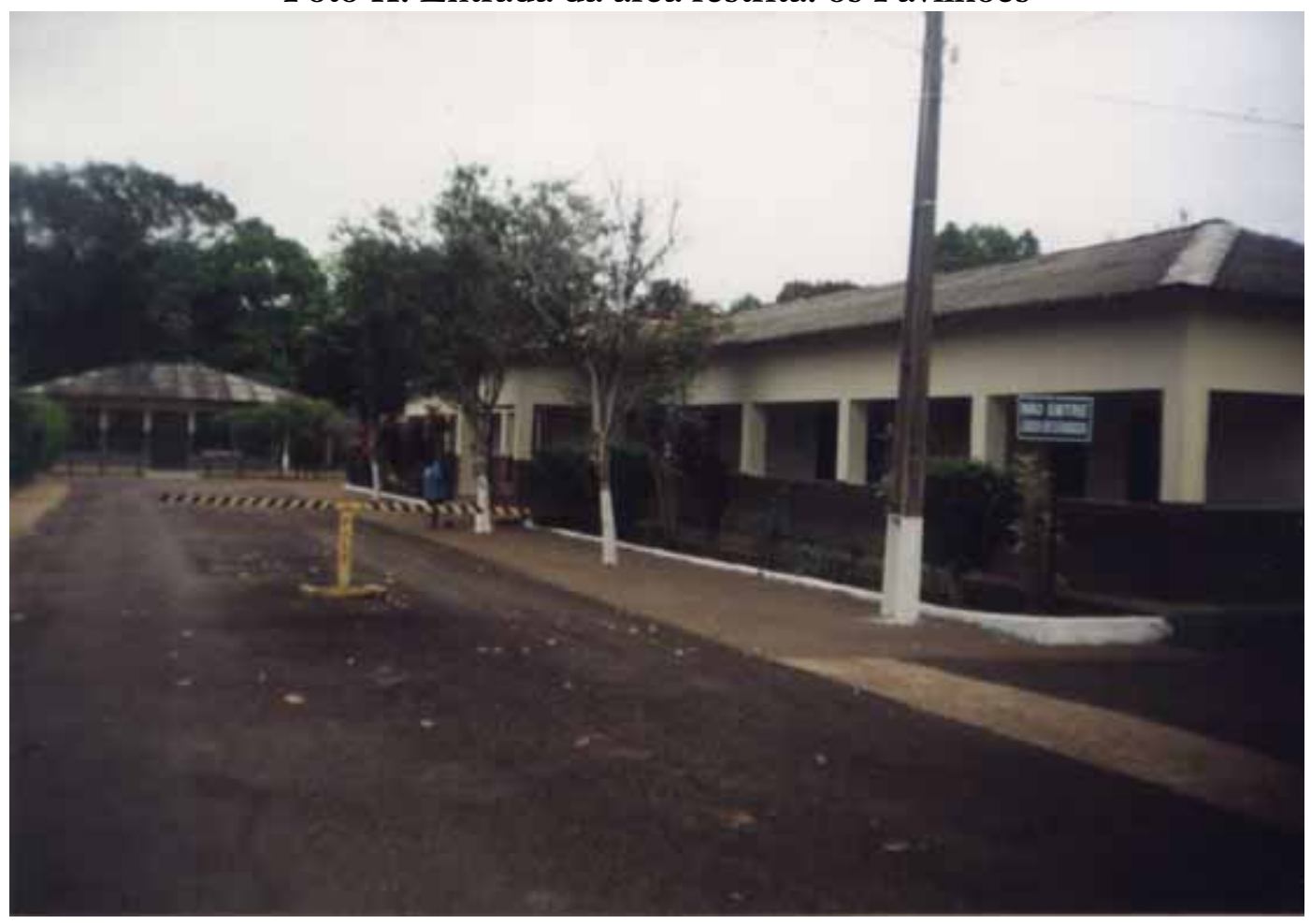

Foto 12: Área Comum: com televisão, um espaço de convivência

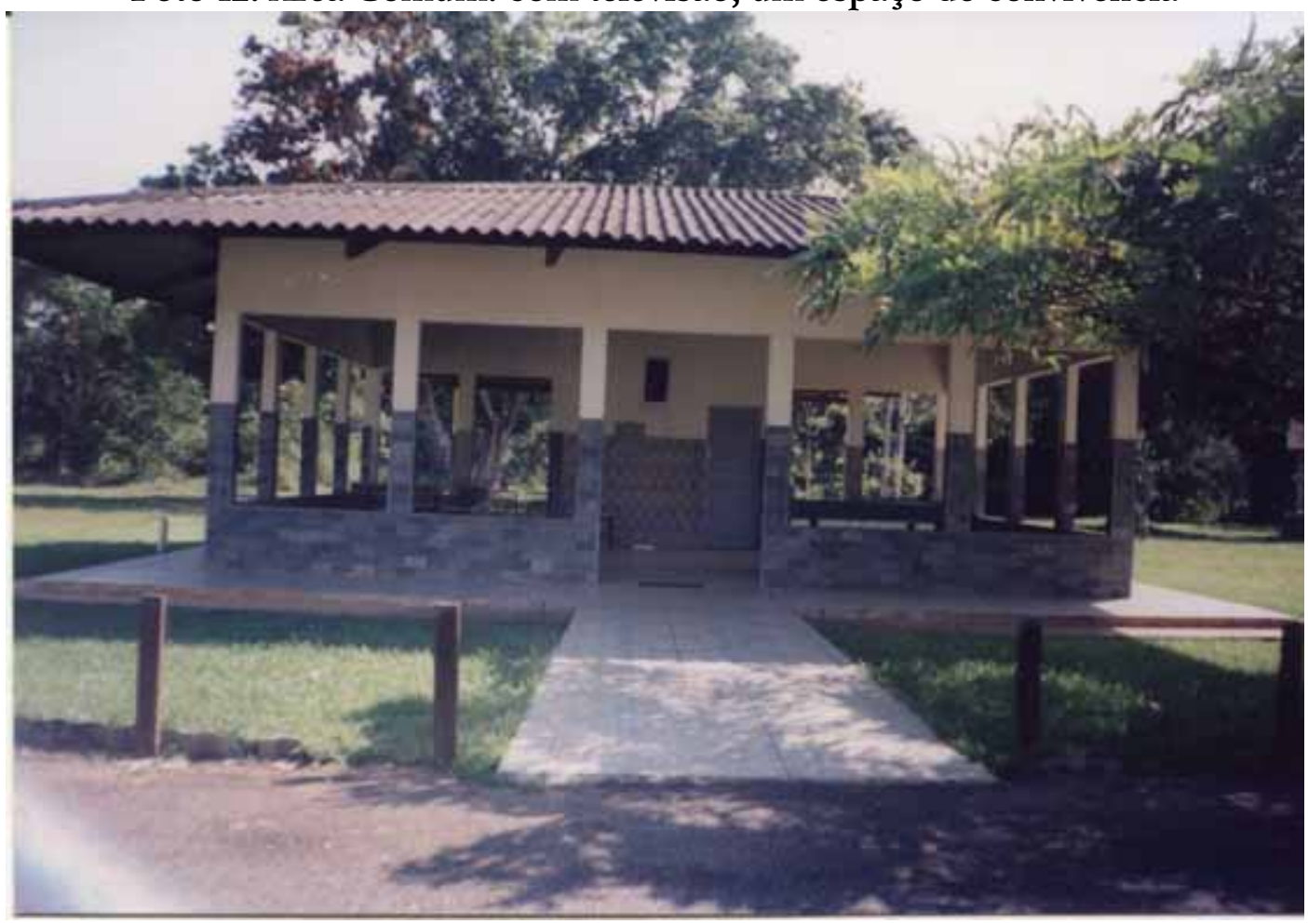


Foto 13: Adálio Mãos

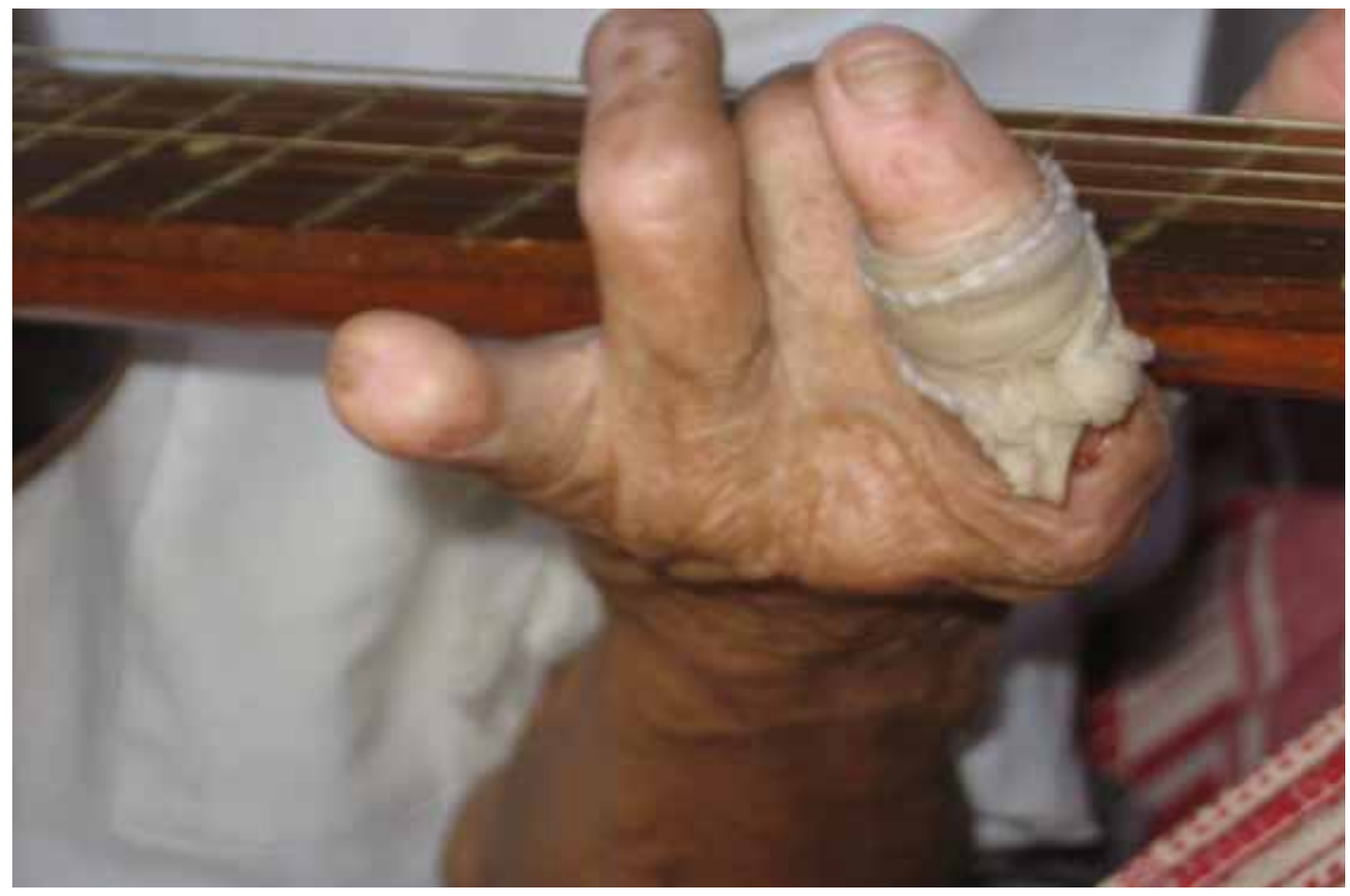

Foto 14: Rádio

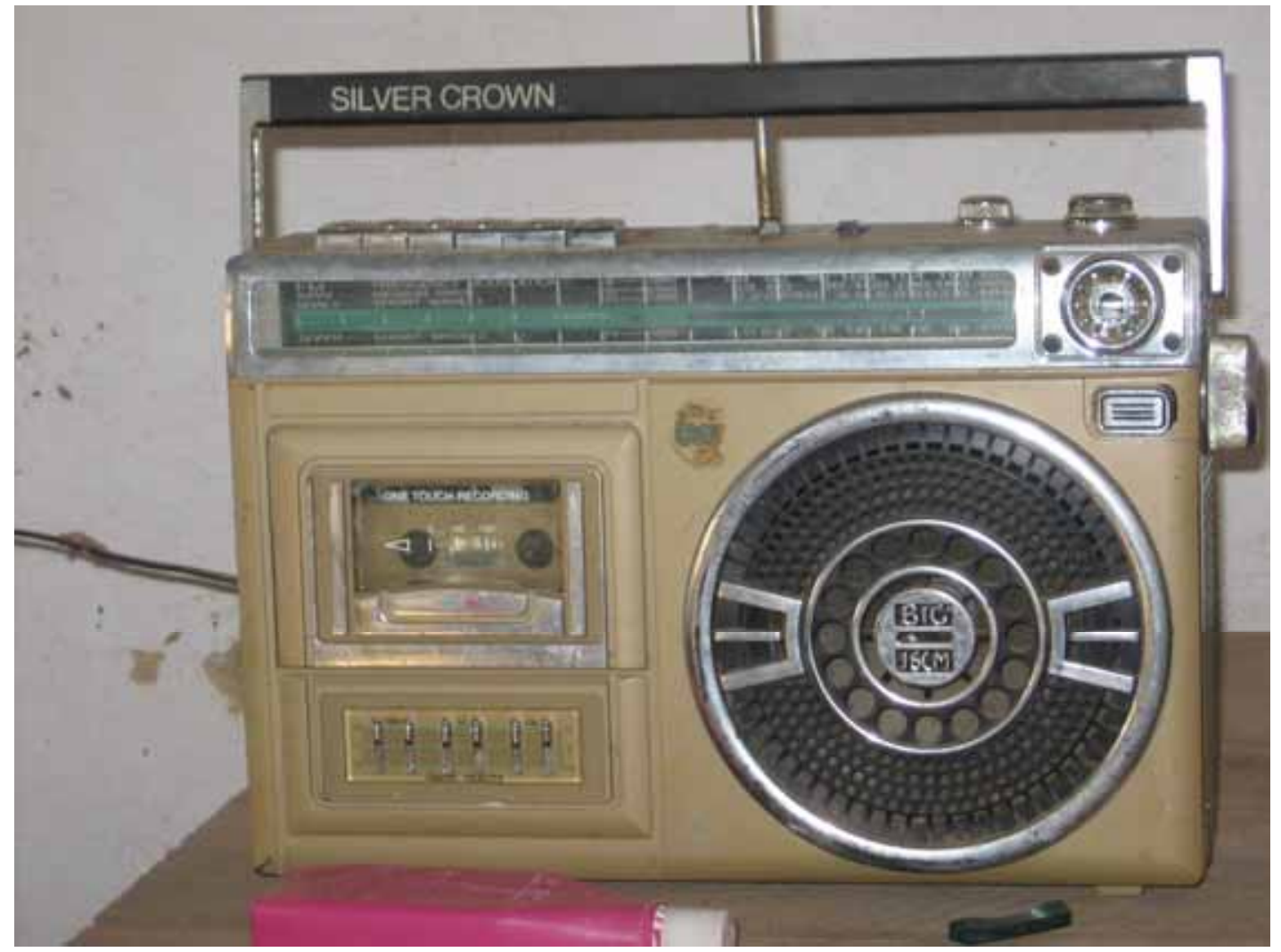


Foto 15: Eu e Adálio na sua casa em Candeias do Jamari: último encontro em maio de 2005

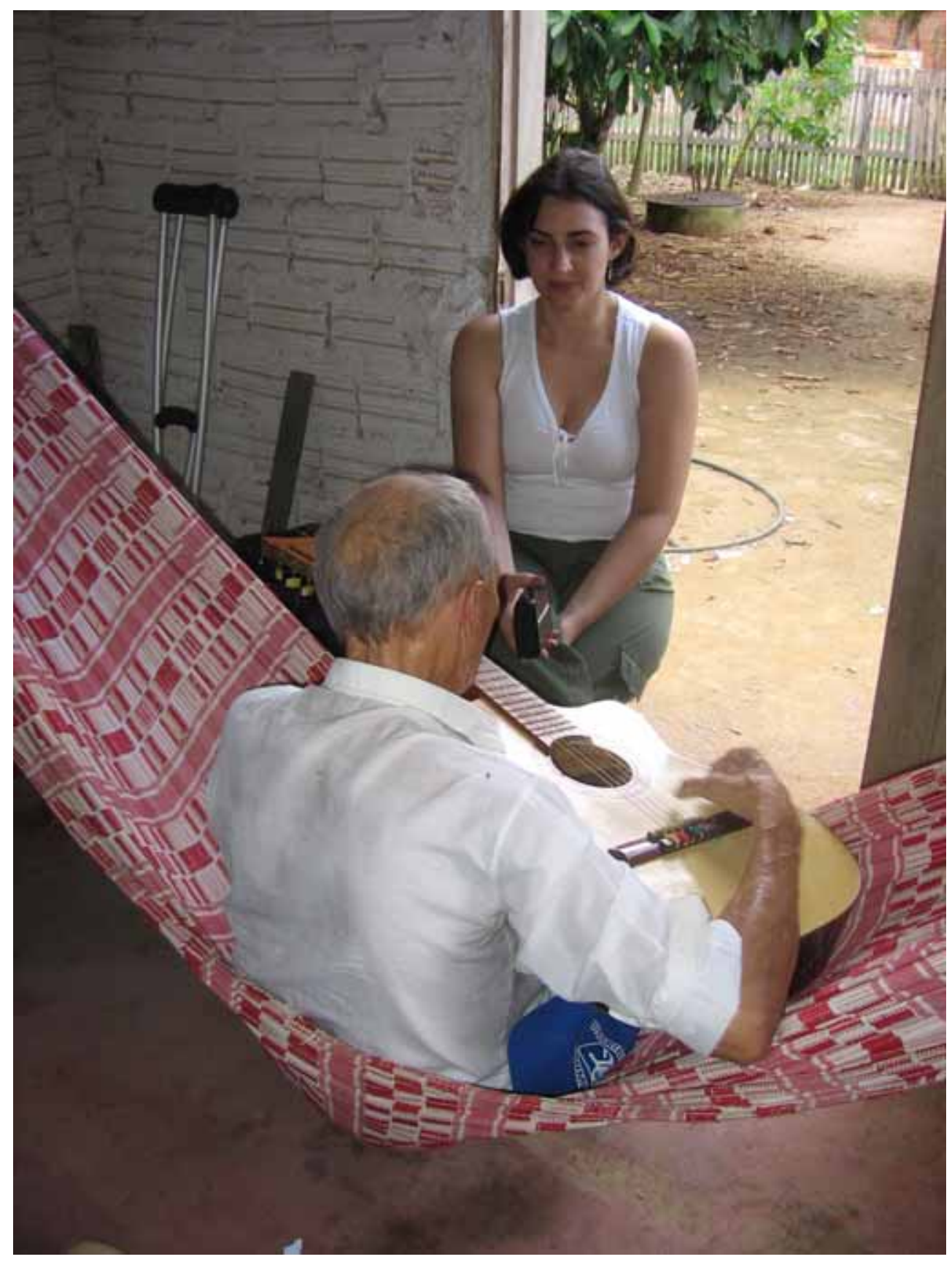


Foto 16: Adálio

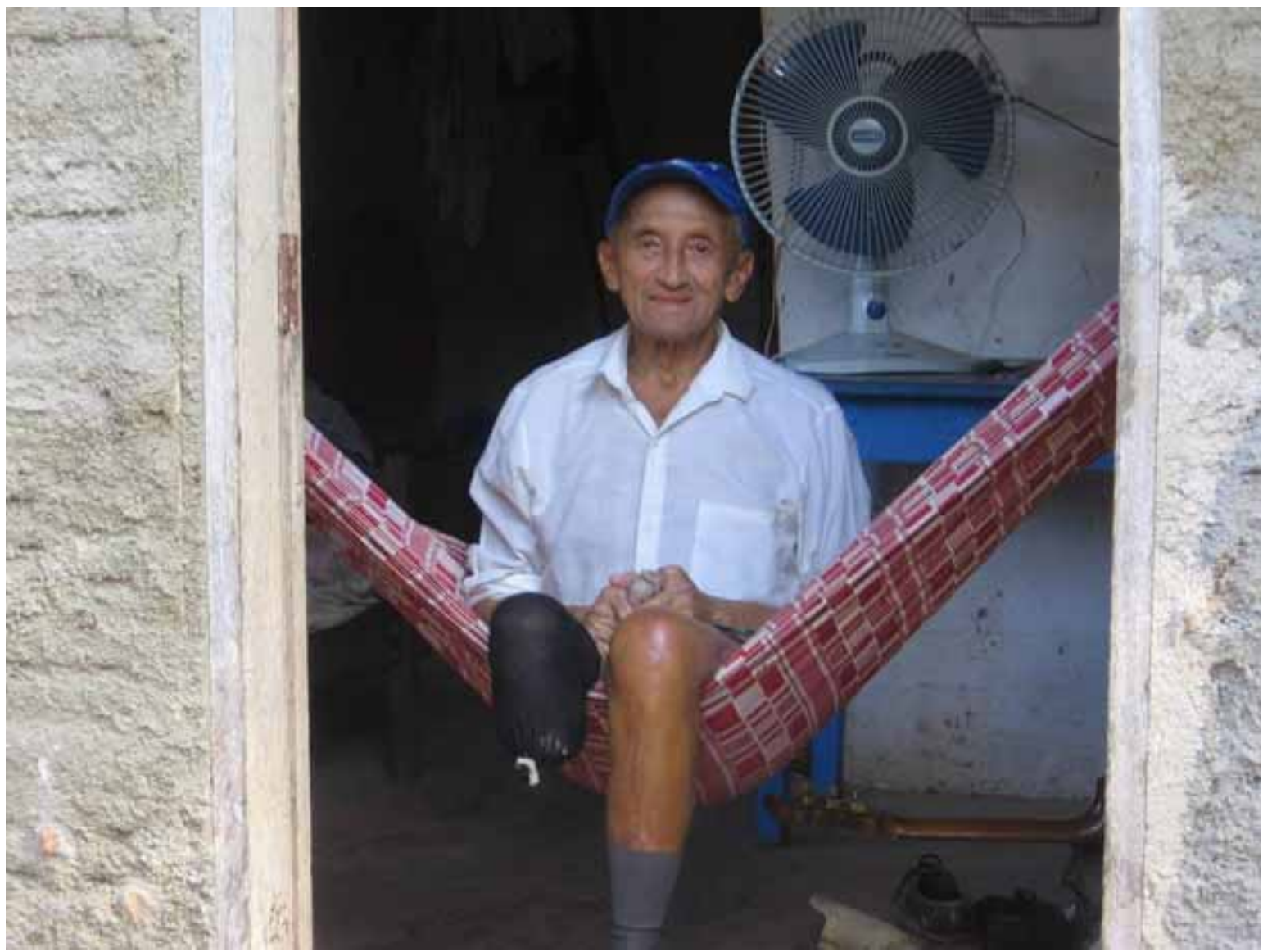

Foto 17: $\mathrm{O}$ que lhe restou

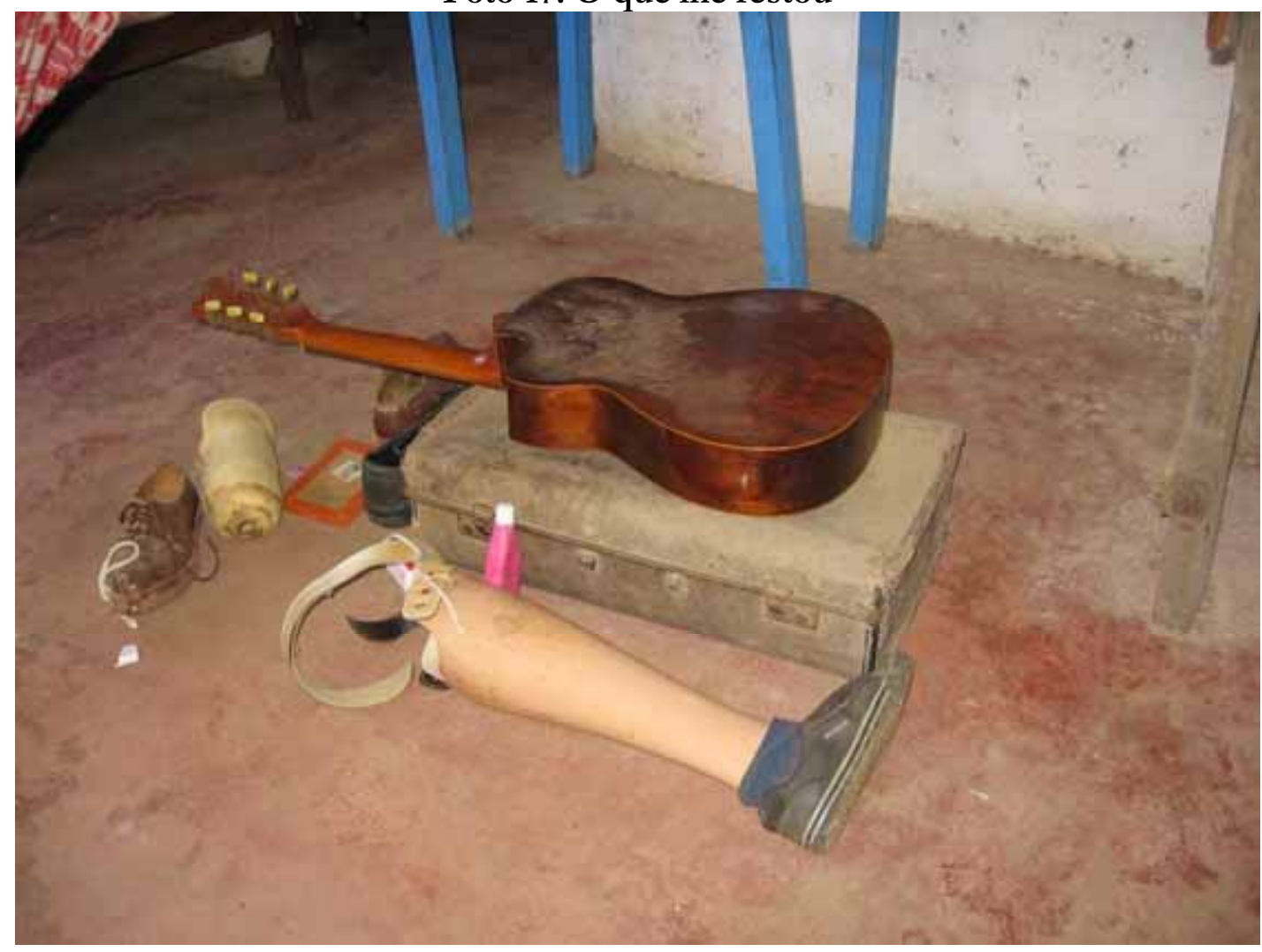

